\title{
Highly Enantioselective Extraction of Phenylglycine by a Chiral Macrocyclic Receptor based on Supramolecular Interactions
}

\author{
María G. Turiel, ${ }^{\dagger}$ José J. Garrido-González, ${ }^{\dagger}$ Luis Simón,${ }^{\dagger}$ Francisca Sanz, ${ }^{\ddagger}$ Anna M. \\ Lithgow, ${ }^{\S}$ Joaquín R. Morán, ${ }^{\dagger}$ Ángel L. Fuentes de Arriba, ${ }^{*}{ }^{\dagger}$ and Victoria Alcázar* ${ }^{*}$ \\ rOrganic Chemistry Department, University of Salamanca, Plaza de los Caídos 1-5, Salamanca E-37008, Spain \\ ${ }^{+} X-R a y$ Diffraction Service, University of Salamanca, Plaza de los Caídos 1-5, Salamanca E-37008, Spain \\ ${ }^{\S}$ Nucleus Platform NMR Service, University of Salamanca, Plaza de los Caídos, 1-5, Salamanca E-37008, Spain \\ 'Department of Chemical and Environmental Engineering, Polytechnical University of Madrid, C/ José \\ Gutiérrez Abascal 2, Madrid E-28006, Spain
}

\section{TABLE OF CONTENTS}

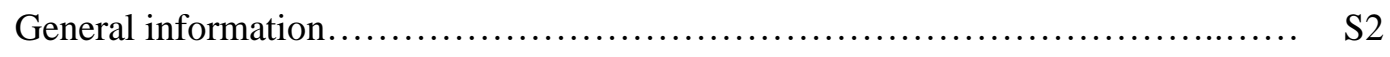

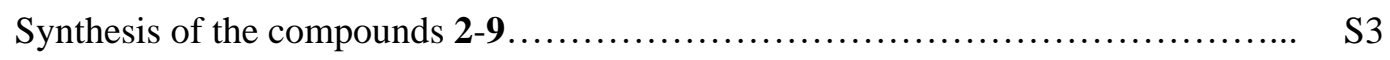

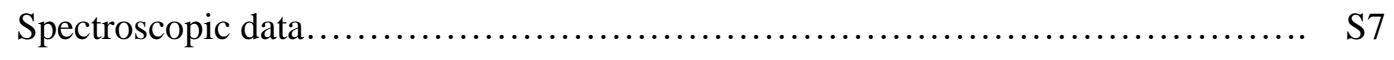

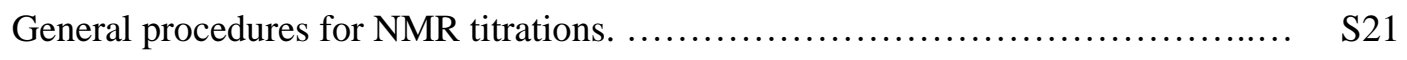

Selected binding curves............................................ S22

General procedure for amino acid extraction. ${ }^{1} \mathrm{H}$ NMR spectra................... S25

Resolution of enantiomers of the macrocyclic receptor $\mathbf{2}$ using TLC impregnated

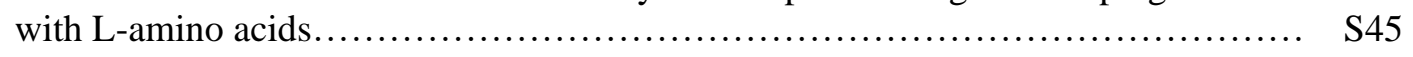

Chiral HPLC chromatograms......................................... S46

ORTEP diagrams and X-ray crystal structure data........................ S50

Modelization studies................................................... S56

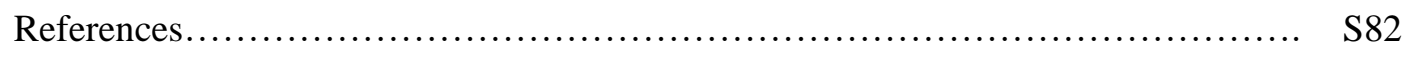




\section{GENERAL INFORMATION}

Solvents were purified by standard procedures and distilled before use. Reagents and starting materials from commercial suppliers were used without further purification. Reactions were monitored by analytical thin-layer chromatography (TLC) using pre-coated aluminium-backed plates and visualized by UV light. Column chromatography was carried out on silica gel (70-200 mesh).

${ }^{1} \mathrm{H}$ NMR and ${ }^{13} \mathrm{C}$ NMR spectra were recorded at room temperature using either a Varian Mercury 200 MHz, Bruker WP-200-SY, Bruker Advance DRX or Bruker Avance NEO 400 with a Prodigy CPPBBO BB-H\&F z-gradient cryo-probe spectrometers. Chemical shifts $(\delta)$ are given in ppm with the solvent signal as internal standard unless otherwise stated $\left(\mathrm{CHCl}_{3} 7.26 \mathrm{ppm}\right.$ for ${ }^{1} \mathrm{H} \mathrm{NMR}, \mathrm{CDCl}_{3} 77.0 \mathrm{ppm}$ for ${ }^{13} \mathrm{C}$ NMR; $\mathrm{CH}_{3} \mathrm{OH} 3.31 \mathrm{ppm}$ for ${ }^{1} \mathrm{H}$ NMR, $\mathrm{CD}_{3} \mathrm{OD} 49.0 \mathrm{ppm}$ for ${ }^{13} \mathrm{C}$ NMR; DMSO 2.50 for ${ }^{1} \mathrm{H}$ NMR, DMSO- $d_{6} 39.52$ for ${ }^{13} \mathrm{C}$ NMR). Coupling constants (J) are reported in $\mathrm{Hz}$. The following abbreviations were used to explain the multiplicities: s, singlet; $d$, doublet; t, triplet; q, quartet; m, multiplet.

Melting points were determined using a Leica Galen III microscope and are given in ${ }^{\circ} \mathrm{C}$.

IR spectra were recorded as films (Nujol) with a Nicolet IR100 spectrometer and frequencies are given in $\mathrm{cm}^{-1}$.

Mass spectra were recorded with an Applied Biosystems QSTAR XL using ESI and a quadrupole TOF mass analyzer. Enantiomeric excess (ee) was determined with an Agilent 1100 series HPLC, using a Daicel CHIRALPAK ZWIX(+) (analytical Column, $3 \mu \mathrm{m}$, ID $3.0 \mathrm{~mm}$ x L $150 \mathrm{~mm}$ ) and a mixture of two solvent systems as eluent: solvent A 98:2 (4:1 mixture of acetonitrile and methanol/ water containing $20 \mathrm{mM}$ formic acid and $20 \mathrm{mM}$ ammonium formate) and solvent B 98:2 (methanol/ water containing $40 \mathrm{mM}$ formic acid and $20 \mathrm{mM}$ ammonium formate). 


\section{SYNTHESIS OF COMPOUNDS 2-9}

\section{Synthesis of racemic macrocycle 2 through disconnections $a$ and $b$}

\section{Route a}<smiles>CCCCOc1ccc2cc(S(=O)(=O)Cl)ccc2c1-c1c(OCCCC)ccc2cc(S(=O)(=O)Cl)ccc12</smiles>

Scheme S1. Retrosynthetic analysis via route $a$.

\section{$N^{1}, N^{8}$-bis(2-aminoethyl)-3,6-di-tert-butyl-9H-carbazole-1,8-disulfonamide (6)}

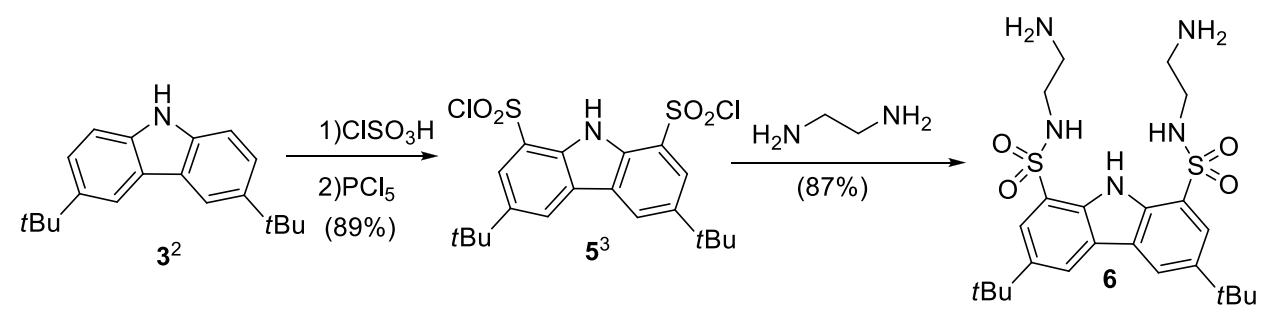

Compounds $\mathbf{3}$ and $\mathbf{5}$ were prepared according to published procedures. ${ }^{[2],[3]}$ To a solution of ethylendiamine $(2.05 \mathrm{~mL}, 30 \mathrm{mmol})$ in methylene chloride $(100 \mathrm{~mL})$ was added dropwise a solution of the disulfonyl dichloride $5(1.60 \mathrm{~g}, 3.38 \mathrm{mmol})$ in $\mathrm{CH}_{2} \mathrm{Cl}_{2}(60 \mathrm{~mL})$ with continuous stirring. Once the addition of the disulfonyl dichloride $\mathbf{5}$ was finished, stirring was kept until the reaction was complete. The progress of the reaction could be monitored by TLC (methylene chloride as eluent). Then, the solvent was removed under reduced pressure and the crude residue was triturated with water. The precipitate thus obtained was filtered, washed and dried under vacuum, to afford $1.52 \mathrm{~g}(87 \%)$ of the desired diamine 6 as a pale yellow crystalline solid. m.p. $147{ }^{\circ} \mathrm{C} .{ }^{1} \mathrm{H}$ NMR $\left(200 \mathrm{MHz}, \mathrm{CDCl}_{3} / 5 \%\right.$ $\left.\mathrm{CD}_{3} \mathrm{OD}\right): \delta=8.26(\mathrm{~d}, J=1.6 \mathrm{~Hz}, 2 \mathrm{H}), 7.89(\mathrm{~d}, J=1.6 \mathrm{~Hz}, 2 \mathrm{H}), 3.61\left(\mathrm{br} \mathrm{s}, 4 \mathrm{H}, \mathrm{NH}_{2}\right), 3.01-2.86(\mathrm{~m}$, $2 \mathrm{H}), 2.77-2.64(\mathrm{~s}, 2 \mathrm{H}), 1.42(\mathrm{~s}, 18 \mathrm{H}) .{ }^{13} \mathrm{C} \mathrm{NMR}\left(50 \mathrm{MHz}, \mathrm{CDCl}_{3} / 5 \% \mathrm{CD}_{3} \mathrm{OD}\right) \delta=143.3,134.0,124.6$, 123.6, 121.6, 121.2, 44.9, 40.8, 34.9, 31.6. IR (Nujol): $\mathrm{cm}^{-1}$ 3423, 3098, 2955, 2864, 1612, 1573, 1495, 1437, 1327, 1288, 1197, 1145, 1041, 963, 898, 736. HRMS (ESI-QTOF) Calcd for $\mathrm{C}_{24} \mathrm{H}_{38} \mathrm{~N}_{5} \mathrm{O}_{4} \mathrm{~S}_{2}$ $[\mathrm{M}+\mathrm{H}]^{+}$524.2359, found 524.2354.

\section{2,2'-dibutoxy-1,1'-binaphthalene (7)}

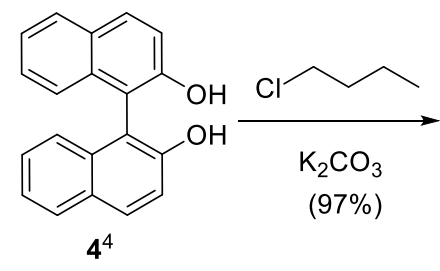<smiles>CCCOc1ccc2ccccc2c1-c1c(OCC)ccc2ccccc12</smiles>

Compound $\mathbf{4}$ was prepared according to the literature ${ }^{[4]}$ Compound $\mathbf{8}$ has been previously prepared in our group ${ }^{[5]}$ but here we include the detailed procedures for compounds 7 and $\mathbf{8}$. 1,1'-binaphthyl-2,2'diol (BINOL) $4(20.0 \mathrm{~g}, 69.9 \mathrm{mmol})$ was dissolved in DMF $(300 \mathrm{~mL})$ in a $1 \mathrm{~L}$ round-bottom flask equipped with magnetic stirrer, condenser and under argon. Finely powdered $\mathrm{K}_{2} \mathrm{CO}_{3}(138.0 \mathrm{~g}, 1 \mathrm{~mol})$ was added followed by addition of butyl chloride in excess $(40 \mathrm{~mL}, 380 \mathrm{mmol})$ and the reaction mixture was heated in an oil bath at $110^{\circ} \mathrm{C}$ for 5 hours. Once the reaction was finished, the mixture was poured 
onto water and extracted several times with ethyl acetate. The combined organic layers were dried over sodium sulfate and the organic solvent was removed under reduced pressure. The crude residue was purified by crystallization $\left(\mathrm{CH}_{2} \mathrm{Cl}_{2} /\right.$ hexane) to afford $27.04 \mathrm{~g}(97 \%)$ of the desired compound 7 as a white crystalline solid. m.p. $90^{\circ} \mathrm{C} .{ }^{1} \mathrm{H}$ NMR $\left(200 \mathrm{MHz}, \mathrm{CDCl}_{3}\right): \delta=7.95(\mathrm{~d}, J=9.0 \mathrm{~Hz}, 2 \mathrm{H}), 7.87(\mathrm{~d}, J$ $=7.9 \mathrm{~Hz}, 2 \mathrm{H}), 7.43(\mathrm{~d}, J=9.0 \mathrm{~Hz}, 2 \mathrm{H}), 7.38-7.25(\mathrm{~m}, 2 \mathrm{H}), 7.24-7.14(\mathrm{~m}, 4 \mathrm{H}), 4.07-3.86(\mathrm{~m}, 4 \mathrm{H})$, $1.50-1.31(\mathrm{~m}, 4 \mathrm{H}), 1.12-0.90(\mathrm{~m}, 4 \mathrm{H}), 0.66(\mathrm{t}, J=7.2 \mathrm{~Hz}, 6 \mathrm{H}) .{ }^{13} \mathrm{C}$ NMR $\left(50 \mathrm{MHz}, \mathrm{CDCl}_{3}\right): \delta=$ 154.6, 134.3, 129.3, 129.1, 127.8, 126.0, 125.6, 123.4, 120.7, 115.9, 69.4, 31.5, 18.8, 13.6. IR $\left(\mathrm{CH}_{2} \mathrm{Cl}_{2}\right)$ $\mathrm{cm}^{-1}: 3377,3046,2955,2936,2871,1619,1593,1508,1469,1333,1275,1255,1080,821,756$. HRMS (ESI-QTOF) Calcd for $\mathrm{C}_{28} \mathrm{H}_{31} \mathrm{O}_{2}[\mathrm{M}+\mathrm{H}]^{+}$399.2319, found 399.2323.

\section{2,2'-dibutoxy-1,1'-binaphthyl-6,6'-disulfonyl dichloride (8)}
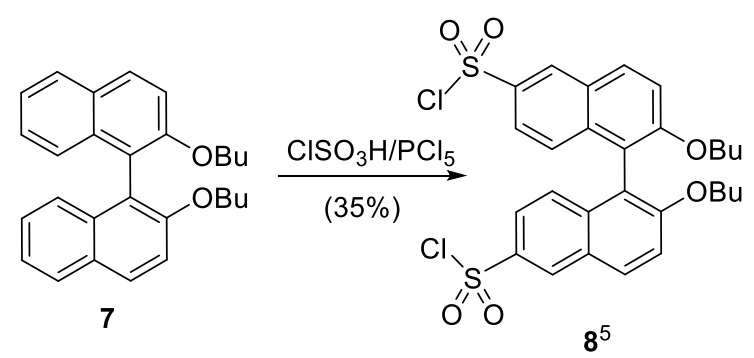

Compound 7 (10.0 g, $25.0 \mathrm{mmol})$ was dissolved in methylene chloride $(300 \mathrm{~mL})$ in a three necked round bottom flask, equipped with magnetic stirrer, a pressure-equalising dropping funnel and under argon atmosphere. The reaction mixture was cooled down to $-20^{\circ} \mathrm{C}$. Then, a solution of chlorosulfonic acid $(4.5 \mathrm{~mL}, 65 \mathrm{mmol})$ in methylene chloride $(5 \mathrm{~mL})$ was added dropwise and the reaction mixture was stirred for one hour. The progress of the reaction could be monitored by ${ }^{1} \mathrm{H}$ NMR analysis of aliquots. Once starting material was no longer present, a bubbler was mounted to the flask and $\mathrm{PCl}_{5}$ in excess $(21.4 \mathrm{~g}, 101.33 \mathrm{mmol})$ was added. The mixture was stirred until evolution of gas ceased. ${ }^{1} \mathrm{H}$ NMR spectra of aliquots allowed us to follow the progress of the reaction and, if necessary, small amounts of $\mathrm{PCl}_{5}$ could be added until the reaction finished. Then, the reaction mixture was poured onto ice and water. The organic layer was separated and the aqueous phase was extracted several times with ethyl acetate. The combined organic layers were dried with $\mathrm{Na}_{2} \mathrm{SO}_{4}$ and the solvents were evaporated. Silica gel column chromatography with $\mathrm{CH}_{2} \mathrm{Cl}_{2}$ afforded the disulfonyl dichloride $\mathbf{8}$ as a yellow crystalline solid $(5.6 \mathrm{~g}, 35 \%) .{ }^{1} \mathrm{H}$ NMR $\left(200 \mathrm{MHz}, \mathrm{CDCl}_{3}\right): \delta=8.64(\mathrm{~s}, 2 \mathrm{H}), 8.20(\mathrm{~d}, J=8.9 \mathrm{~Hz}, 2 \mathrm{H})$, $7.75(\mathrm{~d}, J=8.3 \mathrm{~Hz}, 2 \mathrm{H}), 7.62(\mathrm{~d}, J=8.9 \mathrm{~Hz}, 2 \mathrm{H}), 7.27(\mathrm{~d}, J=8.3 \mathrm{~Hz}, 2 \mathrm{H}), 4.09$ (t, $J=6.8 \mathrm{~Hz}, 4 \mathrm{H}), 1.52-$ $1.40(\mathrm{~m}, 4 \mathrm{H}), 1.10-0.90(\mathrm{~m}, 4 \mathrm{H}), 0.65(\mathrm{t}, J=6.8 \mathrm{~Hz}, 6 \mathrm{H}) .{ }^{13} \mathrm{C} \mathrm{NMR}\left(50 \mathrm{MHz}, \mathrm{CDCl}_{3}\right): \delta=158.1,138.5$, $136.7,132.3,129.5,126.9,126.7,121.8,118.7,116.5,68.8,31.0,18.7,13.5$. Compound $\mathbf{8}$ is relatively unstable and no further characterization was done.

\section{Synthesis of the racemic macrocycle 2}
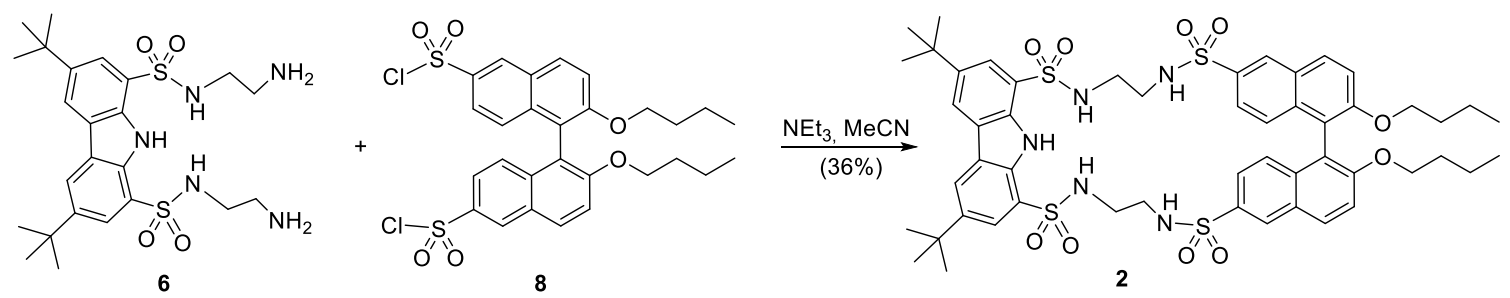

Acetonitrile $(400 \mathrm{~mL})$ and triethyl amine $(6.0 \mathrm{~mL}, 43.28 \mathrm{mmol})$ were added to a $1 \mathrm{~L}$ 2-neck round bottom flask equipped with magnetic stirrer, two pressure-equalising dropping funnels and under nitrogen atmosphere. A solution of the diamine 6 (1.52 g, $2.90 \mathrm{mmol})$ in $\mathrm{CH}_{3} \mathrm{CN}$ (100 mL) was added to one of the funnels while the disulfonyl dichloride $8(1.73 \mathrm{~g}, 2.90 \mathrm{mmol})$ in $\mathrm{CH}_{3} \mathrm{CN}(100 \mathrm{~mL})$ was put in the other. Next and simultaneously, both solutions were dropwise added and at the same speed. 
Once the additions were finished, stirring was kept until aliquot analysis by TLC and ${ }^{1} \mathrm{H}$ NMR showed that the reaction had finished. The solvent was evaporated and the crude residue was purified by silica gel column chromatography $\left(\mathrm{CH}_{2} \mathrm{Cl}_{2} /\right.$ EtOAc $4: 1$ as eluent) to afford $1.11 \mathrm{~g}(36 \%)$ of the macrocycle 2 as a beige crystalline solide. m.p. $199{ }^{\circ} \mathrm{C} .{ }^{1} \mathrm{H}$ NMR $\left(400 \mathrm{MHz}, \mathrm{CDCl}_{3}\right): \delta=9.81(\mathrm{~s}, 1 \mathrm{H}, \mathrm{NH}), 8.40(\mathrm{~d}, J$ $=1.6 \mathrm{~Hz}, 2 \mathrm{H}), 8.27(\mathrm{~d}, J=1.6 \mathrm{~Hz}, 2 \mathrm{H}), 8.00(\mathrm{~d}, J=9.0 \mathrm{~Hz}, 2 \mathrm{H}), 7.84(\mathrm{~d}, J=1.6 \mathrm{~Hz}, 2 \mathrm{H}), 7.49(\mathrm{dd}, J$ $=8.0,1.6 \mathrm{~Hz}, 2 \mathrm{H}), 7.47(\mathrm{~d}, J=9.0,2 \mathrm{H}), 7.19(\mathrm{~d}, \mathrm{~J}=8.0 \mathrm{~Hz}, 2 \mathrm{H}), 5.58(\mathrm{~s}, 2 \mathrm{H}, \mathrm{NH}), 5.14(\mathrm{~s}, 2 \mathrm{H}, \mathrm{NH})$, 4.02-3.93 (m, 4H), 3.21- $2.99(\mathrm{~m}, 4 \mathrm{H}), 2.98-2.86(\mathrm{~m}, 4 \mathrm{H}), 1.46-1.36(\mathrm{~m}, 4 \mathrm{H}), 1.42(\mathrm{~s}, 18 \mathrm{H}), 1.07-$ $0.96(\mathrm{~m}, 4 \mathrm{H}), 0.66(\mathrm{t}, J=7.2 \mathrm{~Hz}, 6 \mathrm{H}) .{ }^{13} \mathrm{C}$ NMR $\left(100 \mathrm{MHz}, \mathrm{CDCl}_{3}\right): \delta=156.8,143.7,135.7,134.0$, 133.0, 131.0, 128.9, 127.2, 126.8, 124.7, 123.8, 122.7, 122.2, 120.3, 119.2, 116.0, 68.8, 42.7, 42.0, 34.9, 31.7, 31.1, 18.7, 13.5. ${ }^{1} \mathrm{H}$ NMR (400 MHz, DMSO- $\left.d_{6}\right): \delta=9.99(\mathrm{~s}, 1 \mathrm{H}, \mathrm{NH}), 8.67(\mathrm{~d}, J=1.7 \mathrm{~Hz}, 2 \mathrm{H})$, $8.44(\mathrm{~d}, J=1.9 \mathrm{~Hz}, 2 \mathrm{H}), 8.30(\mathrm{~d}, J=9.2 \mathrm{~Hz}, 2 \mathrm{H}), 7.95(\mathrm{t}, J=5.6 \mathrm{~Hz}, 2 \mathrm{H}, \mathrm{NH}), 7.80(\mathrm{~d}, J=1.8 \mathrm{~Hz}$, $2 \mathrm{H}), 7.73(\mathrm{~d}, J=9.3 \mathrm{~Hz}, 2 \mathrm{H}), 7.60(\mathrm{t}, J=5.5 \mathrm{~Hz}, 2 \mathrm{H}, \mathrm{NH}), 7.48(\mathrm{dd}, J=9.0,1.9 \mathrm{~Hz}, 2 \mathrm{H}), 6.95(\mathrm{~d}, J=$ $9.0 \mathrm{~Hz}, 2 \mathrm{H}), 4.12-3.99(\mathrm{~m}, J=10.0,6.4 \mathrm{~Hz}, 4 \mathrm{H}), 2.89-2.63(\mathrm{~m}, 8 \mathrm{H}), 1.42(\mathrm{~s}, 18 \mathrm{H}), 1.40-1.31(\mathrm{~m}$, $J=12.0,7.6,4.5 \mathrm{~Hz}, 4 \mathrm{H}), 1.05-0.89(\mathrm{~m}, 4 \mathrm{H}), 0.61(\mathrm{t}, J=7.4 \mathrm{~Hz}, 6 \mathrm{H}) .{ }^{13} \mathrm{C}$ NMR $(101 \mathrm{MHz}, \mathrm{DMSO}-$ $\left.d_{6}\right): \delta=156.2,142.8,134.7,134.2,133.7,131.2,127.9,127.1,125.5,124.1,122.9,122.8,122.6,68.2$, 42.4, 41.7, 34.8, 31.6, 30.6, 18.2, 13.3. IR $\left(\mathrm{CH}_{2} \mathrm{Cl}_{2}\right) \mathrm{cm}^{-1}: 3429,3273,1619,1463,1333,1281,1145$, 957, 898. HRMS (ESI-QTOF) Calcd for $\mathrm{C}_{52} \mathrm{H}_{63} \mathrm{~N}_{5} \mathrm{O}_{10} \mathrm{~S}_{4} \mathrm{Na}[\mathrm{M}+\mathrm{Na}]^{+} 1068.3350$, found 1068.3352.

\section{Route $b$}

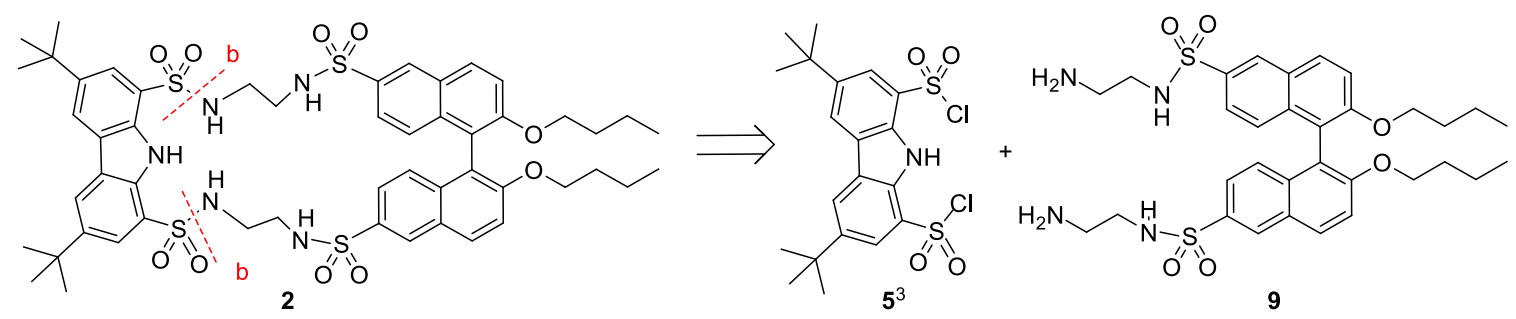

Scheme S2. Retrosynthetic analysis via route $b$.

Compound 5, 3,6-di-tert-butyl-9H-carbazole-1,8-disulfonyl dichloride, was synthesized according to a published procedure. ${ }^{[3]}$

$N^{1}, N^{8}$-bis(2-aminoethyl)-2,2' -dibutoxy-1,1'-binaphthyl-6,6'-disulfonamide (9)<smiles>COc1ccc2cc(S(=O)(=O)Cl)ccc2c1-c1c(C(=O)O)ccc2cc(S(=O)(=O)Cl)ccc12</smiles><smiles>CC(C)CNCCN</smiles><smiles>CCCCOc1ccc2cc(S(=O)(=O)NCCN)ccc2c1-c1c(OCCCC)ccc2cc(S(=O)(=O)NCCN)ccc12</smiles>

To a solution of ethylenediamine $(2.0 \mathrm{~mL}, 30 \mathrm{mmol})$ in diethylether $(120 \mathrm{~mL})$ was added dropwise a solution of the disulfonyl dichloride $8(1.0 \mathrm{~g}, 1.68 \mathrm{mmol})$ in diethylether $(20 \mathrm{~mL})$ with continuous stirring. Once the addition of the disulfonyl dichloride $\mathbf{8}$ was finished, stirring was kept until the reaction was complete. The progress of the reaction could be monitored by ${ }^{1} \mathrm{H}$ NMR analysis of aliquots. Once the reaction was finished, water $(100 \mathrm{~mL})$ was added and the phases were separated. The organic layer was dried with $\mathrm{Na}_{2} \mathrm{SO}_{4}$ and the solvent was evaporated. Column chromatography with methanol/ ethyl acetate $1: 1$ afforded the desired diamine 9 as a yellow crystalline solid $(0.96 \mathrm{~g}, 88 \%)$. m.p. $105^{\circ} \mathrm{C} .{ }^{1} \mathrm{H}$ NMR $\left(200 \mathrm{MHz}, \mathrm{CD}_{3} \mathrm{OD}\right) \delta=8.47(\mathrm{~s}, 2 \mathrm{H}), 8.16(\mathrm{~d}, J=9.1 \mathrm{~Hz}, 2 \mathrm{H}), 7.63(\mathrm{~d}, J=9.1 \mathrm{~Hz}, 2 \mathrm{H}), 7.54(\mathrm{~d}$, $J=9.1 \mathrm{~Hz}, 2 \mathrm{H}), 7.15(\mathrm{~d}, J=8.9 \mathrm{~Hz}, 2 \mathrm{H}), 4.01(\mathrm{t}, J=5.4 \mathrm{~Hz}, 4 \mathrm{H}), 2.96(\mathrm{t}, J=5.9 \mathrm{~Hz}, 4 \mathrm{H}), 2.78(\mathrm{t}, J=$ 
$5.8 \mathrm{~Hz}, 4 \mathrm{H}), 1.47-1.24(\mathrm{~m}, 4 \mathrm{H}), 0.95(\mathrm{td}, J=14.4,7.2 \mathrm{~Hz}, 4 \mathrm{H}), 0.60(\mathrm{t}, J=7.3 \mathrm{~Hz}, 6 \mathrm{H}) .{ }^{13} \mathrm{C}$ NMR $(50$ $\left.\mathrm{MHz}, \mathrm{CD}_{3} \mathrm{OD}\right): \delta=157.1,135.6,134.4,131.2,128.6,127.7,126.3,122.6,119.1,116.2,68.6,43.9$, 40.6, 31.1, 18.7, 12.8. IR $\left(\mathrm{CH}_{2} \mathrm{Cl}_{2}\right) \mathrm{cm}^{-1}: 3280 ; 2955 ; 2923 ; 2865 ; 2365 ; 2326 ; 1619 ; 1502 ; 1469 ; 1327$; $1275 ; 1151 ; 1100 ; 1035$. HRMS (ESI-QTOF) Calcd for $\mathrm{C}_{32} \mathrm{H}_{43} \mathrm{~N}_{4} \mathrm{O}_{6} \mathrm{~S}_{2}[\mathrm{M}+\mathrm{H}]^{+} 643.2618$, found 643.2625 .

\section{Synthesis of the racemic macrocycle 2}
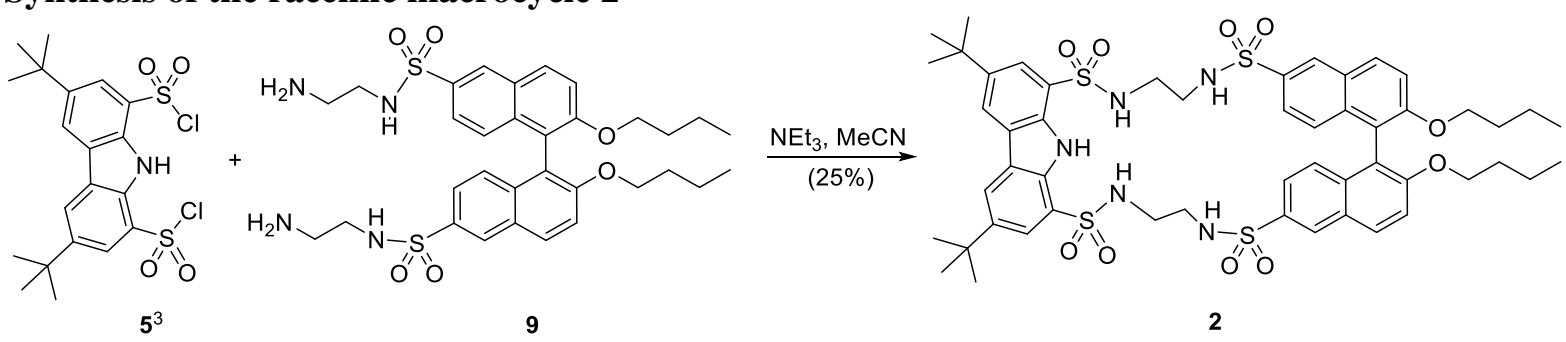

Acetonitrile $(200 \mathrm{~mL})$ and triethyl amine $(3.0 \mathrm{~mL}, 21.64 \mathrm{mmol})$ were added to a 1 Liter 2-neck round bottom flask equipped with magnetic stirrer, two pressure-equalising dropping funnels and under nitrogen atmosphere. A solution of the diamine $9(0.96 \mathrm{~g}, 1.45 \mathrm{mmol})$ in $\mathrm{CH}_{3} \mathrm{CN}(50 \mathrm{~mL})$ was added to one of the funnels while the disulfonyl dichloride $5(0.72 \mathrm{~g}, 1.45 \mathrm{mmol})$ in $\mathrm{CH}_{3} \mathrm{CN}(50 \mathrm{~mL})$ was put in the other. Next and simultaneously, both solutions were dropwise added and at the same speed. Once the additions were finished, stirring was kept until aliquot analysis by TLC and ${ }^{1} \mathrm{H}$ NMR showed that the reaction had finished. The solvent was evaporated and the crude residue was purified by silica gel column chromatography $\left(\mathrm{CH}_{2} \mathrm{Cl}_{2} /\right.$ EtOAc $4: 1$ as eluent) to afford $770 \mathrm{mg}(25 \%)$ of the macrocycle 2 as a beige crystalline solid.

\section{Synthesis of the enantiopure receptor $(S)-2$}

Starting from the 1,1'-binaphthyl-2,2'-diol (BINOL) 4 enantiomerically pure, ${ }^{[6]}$ and following the synthetic strategy via route $a$, the receptor $(S)-2$ was prepared. $[\alpha]_{D}^{20}=105.9 \mathrm{degcm}^{3} \mathrm{~g}^{-1} \mathrm{dm}^{-1}\left(\mathrm{c}=1.0 \mathrm{gcm}^{-3}\right.$ in chloroform). 


\section{SPECTROSCOPIC DATA}

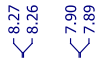
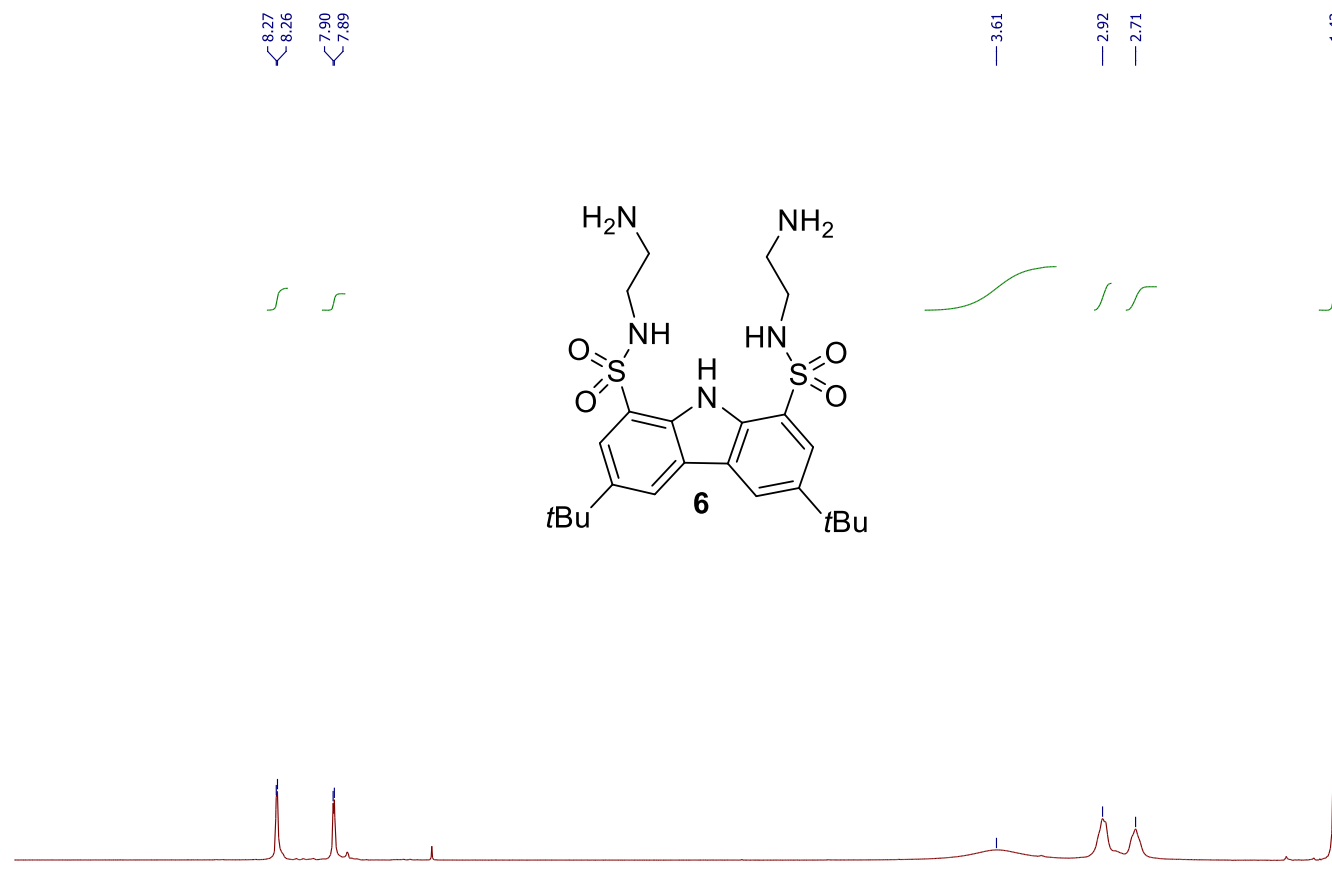

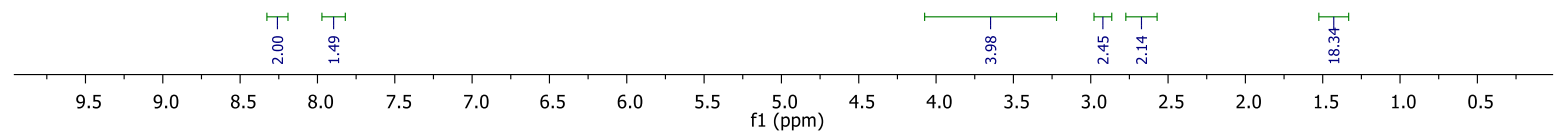

Figure S1. ${ }^{1} \mathrm{H}$ NMR $\left(200 \mathrm{MHz}, \mathrm{CDCl}_{3} / 5 \% \mathrm{CD}_{3} \mathrm{OD}\right)$ spectrum of compound $\mathbf{6}$.

$$
\text { l }
$$
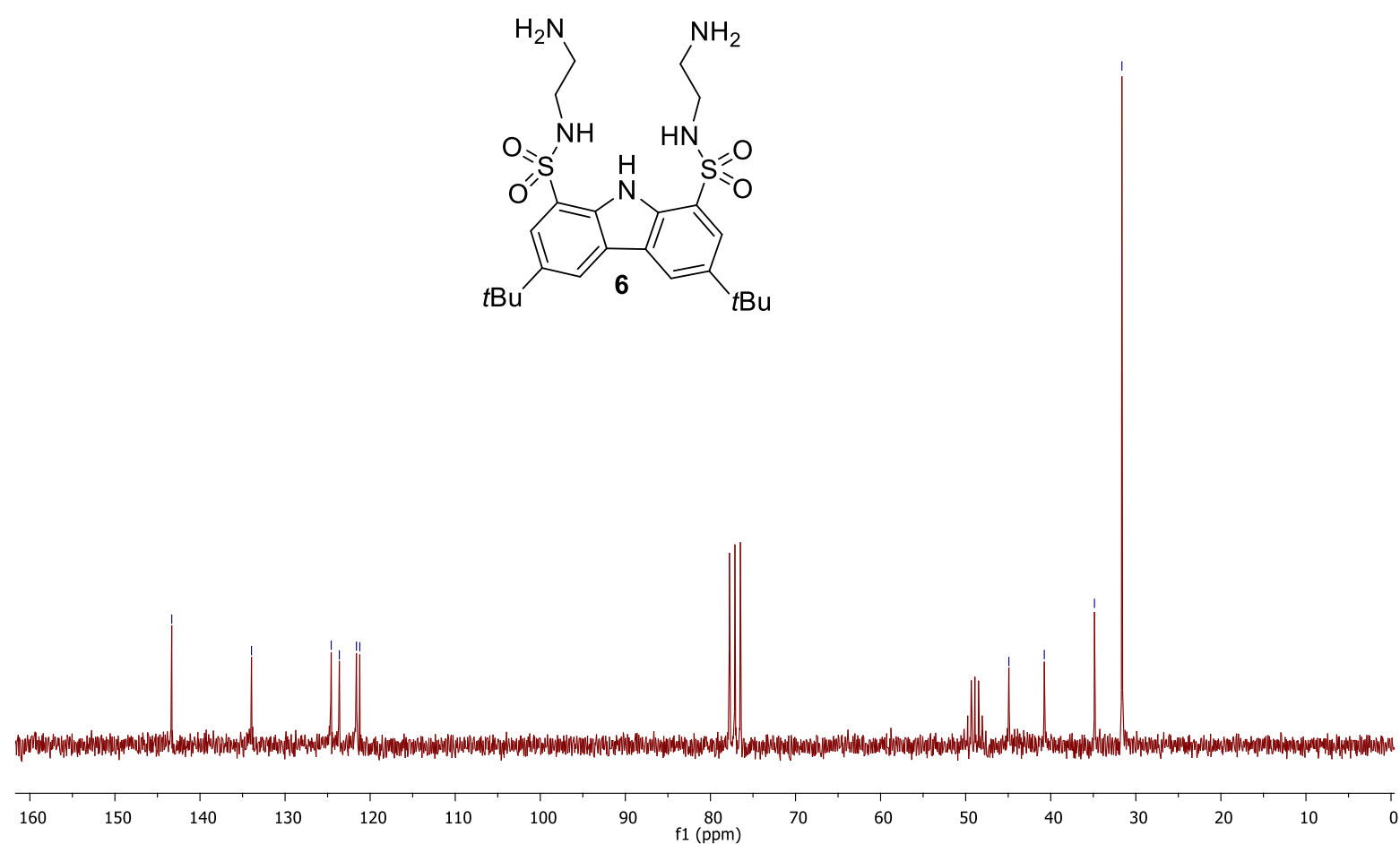

Figure S2. ${ }^{13} \mathrm{C}$ NMR $\left(50 \mathrm{MHz}, \mathrm{CDCl}_{3} / 5 \% \mathrm{CD}_{3} \mathrm{OD}\right)$ spectrum of compound 6 . 


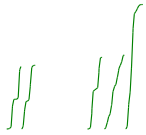<smiles>CCCCOc1ccc2ccccc2c1-c1c(OCCC)ccc2ccccc12</smiles>
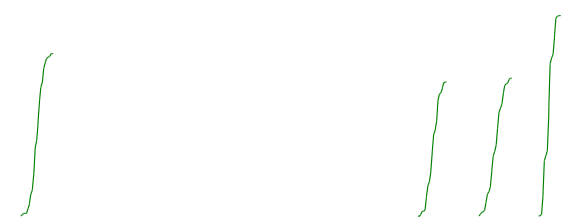

7

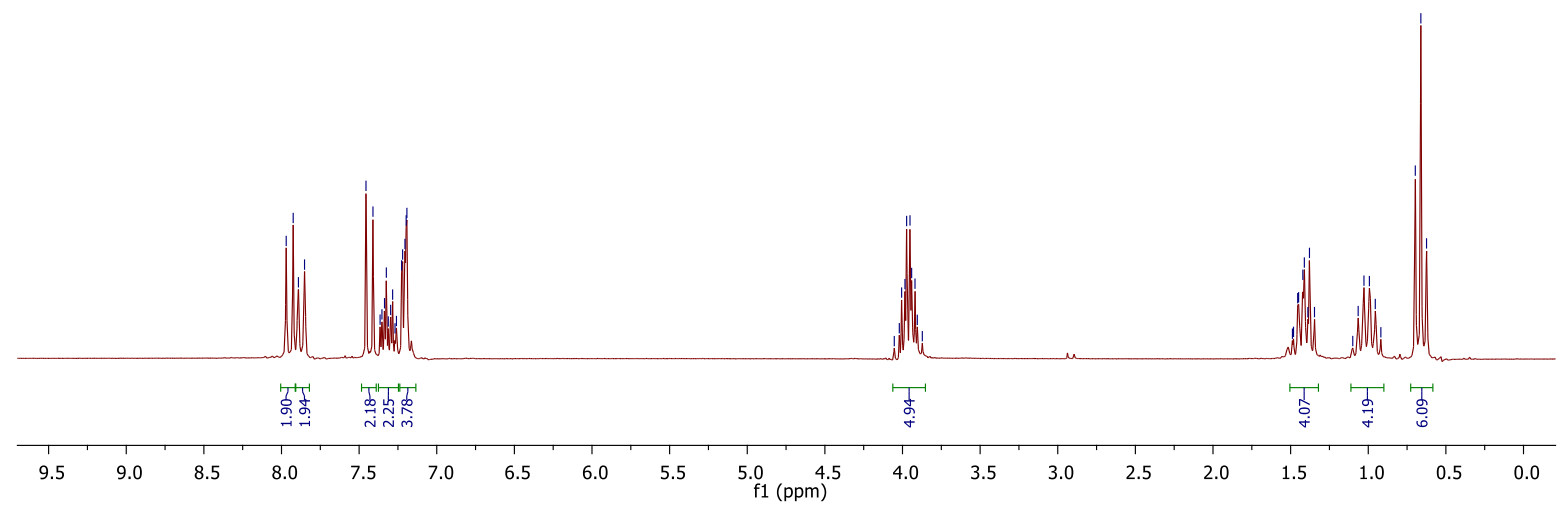

Figure S3. ${ }^{1} \mathrm{H}$ NMR $\left(200 \mathrm{MHz}, \mathrm{CDCl}_{3}\right)$ spectrum of compound 7.

| l|
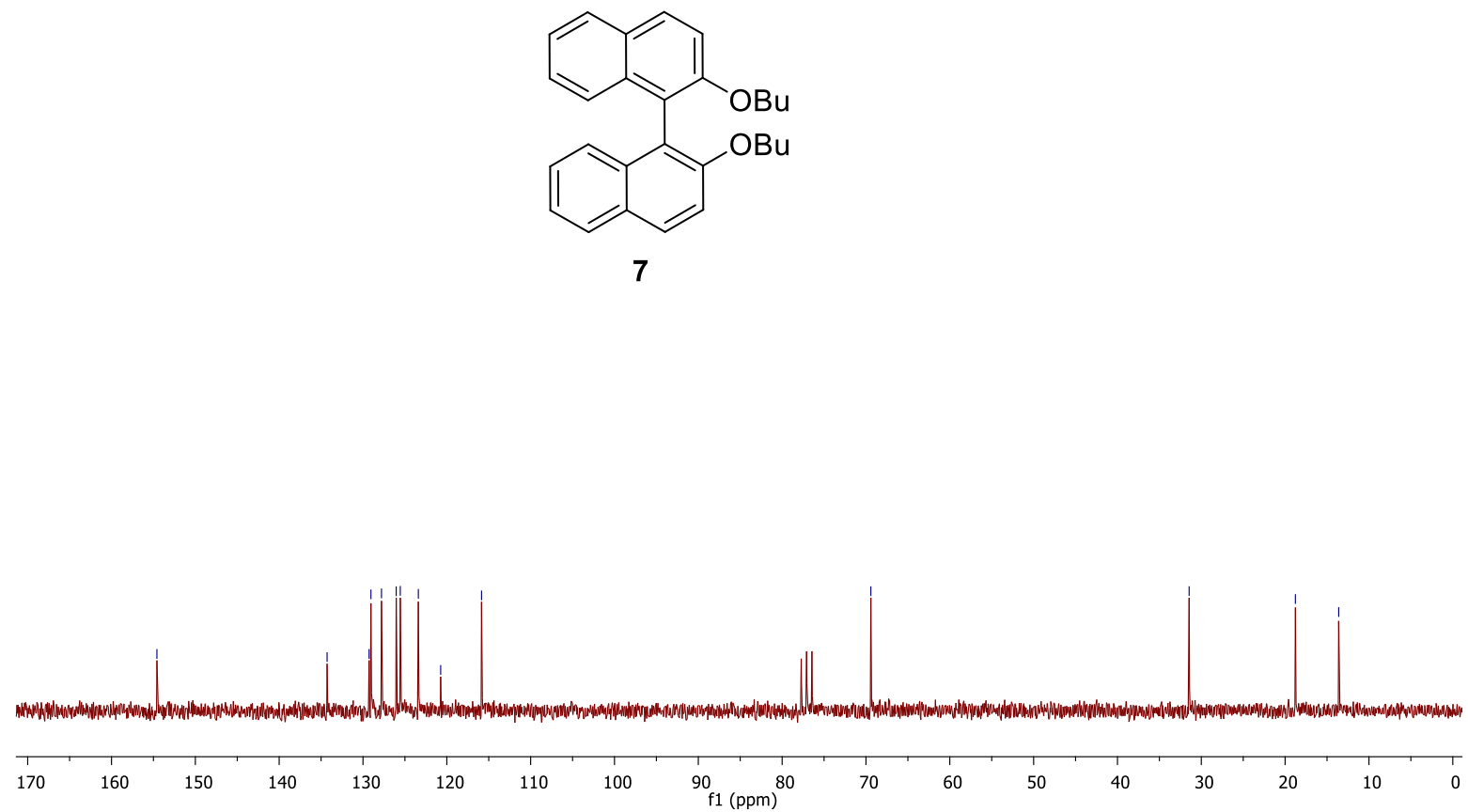

Figure S4. ${ }^{13} \mathrm{C}$ NMR $\left(50 \mathrm{MHz}, \mathrm{CDCl}_{3}\right)$ spectrum of compound 7. 

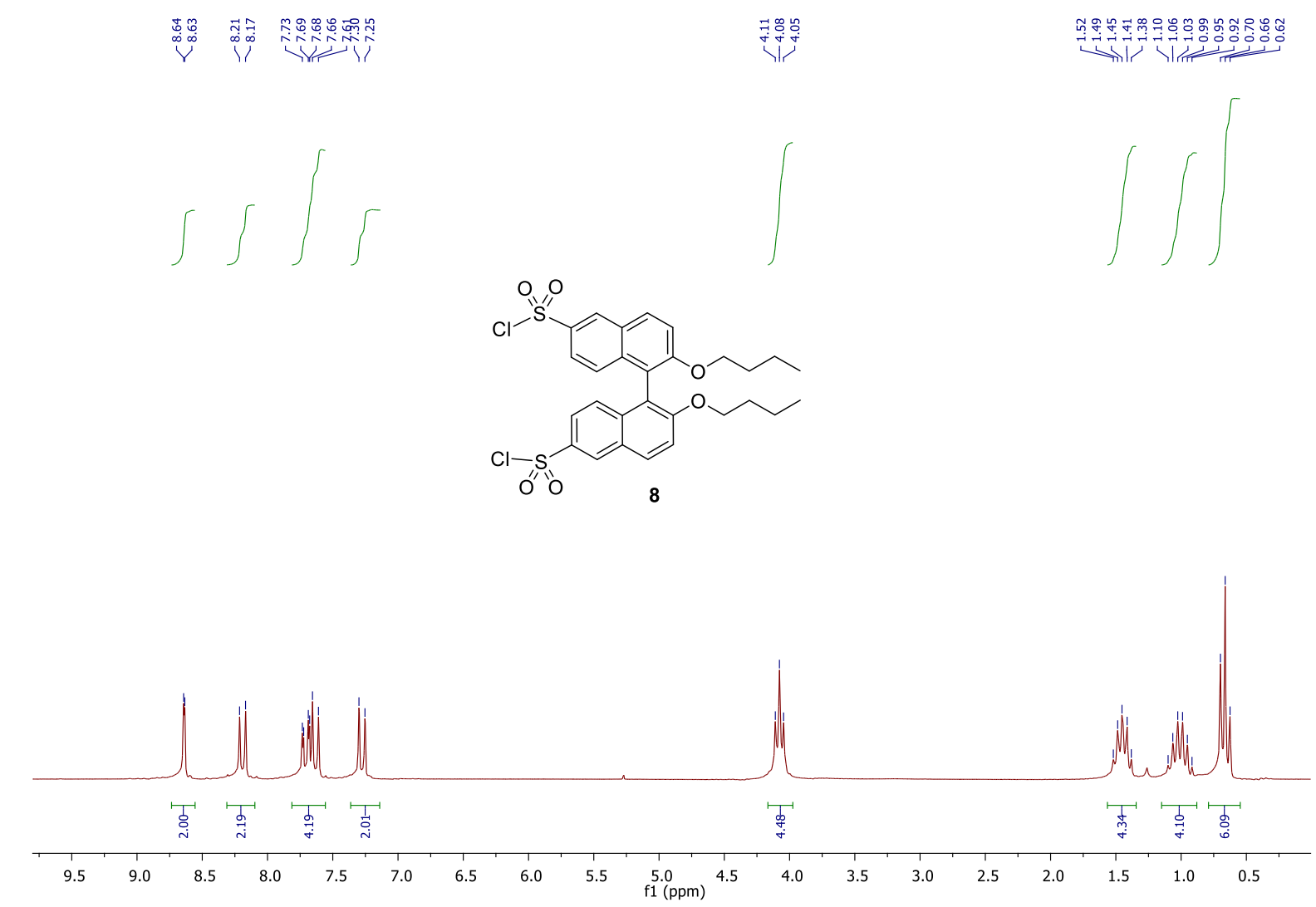

Figure S5. ${ }^{1} \mathrm{H}$ NMR $\left(200 \mathrm{MHz}, \mathrm{CDCl}_{3}\right)$ spectrum of compound 8.
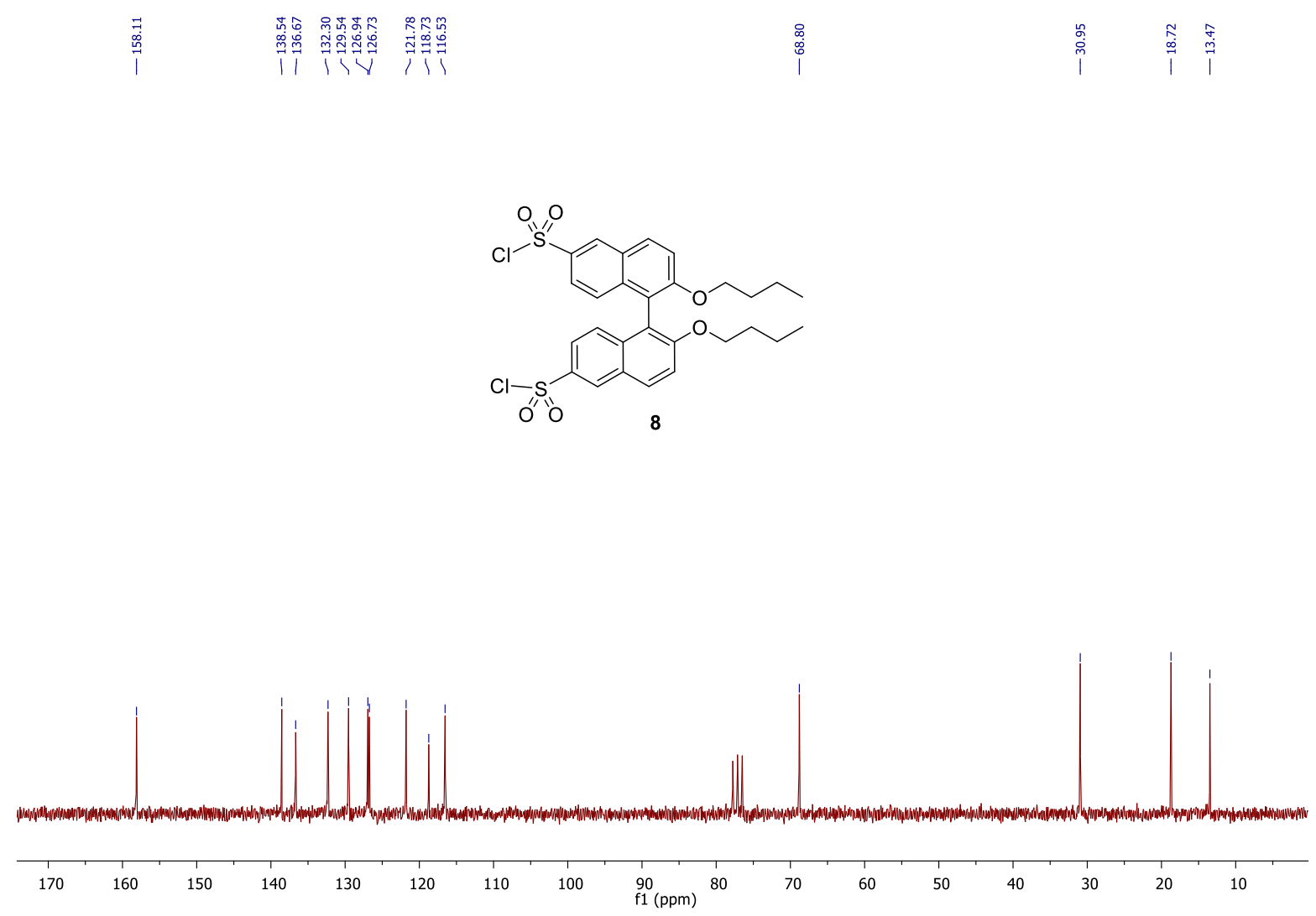

Figure S6. ${ }^{13} \mathrm{C}$ NMR $\left(50 \mathrm{MHz}, \mathrm{CDCl}_{3}\right)$ spectrum of compound $\mathbf{8}$. 


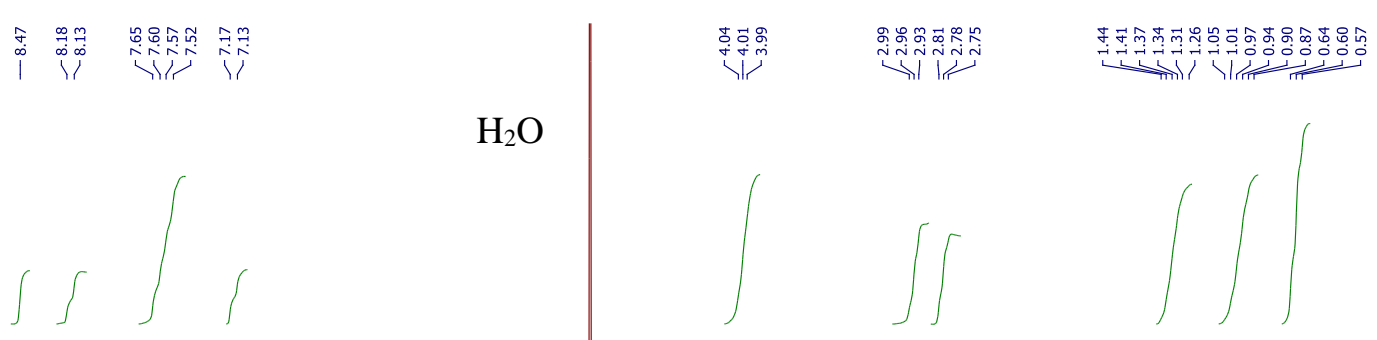<smiles>CCCCCOc1ccc2cc(S(=O)(=O)NCCN)ccc2c1-c1c(OCCCC)ccc2cc(S(=O)(=O)NCCN)ccc12</smiles>

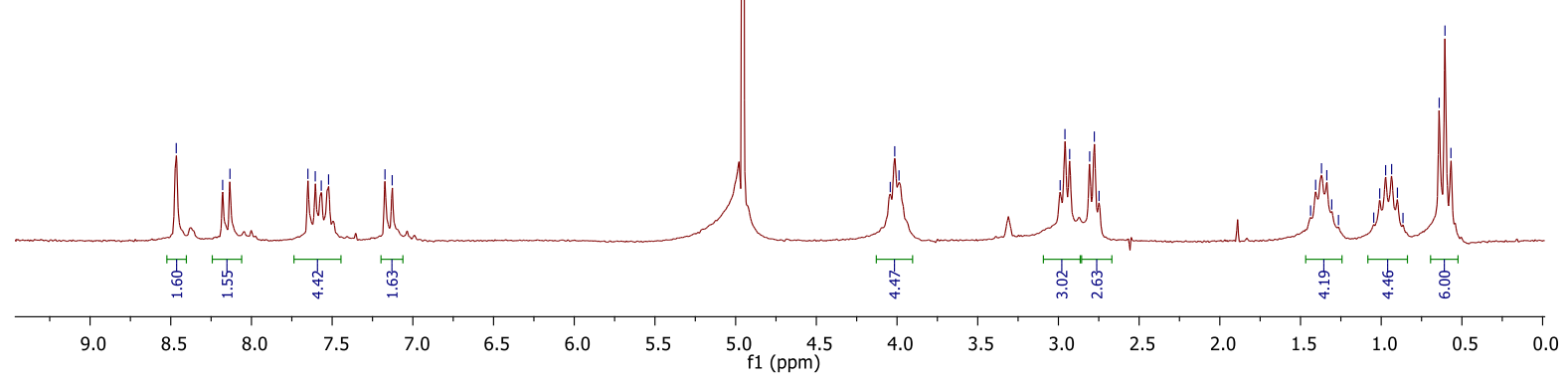

Figure S7. ${ }^{1} \mathrm{H}$ NMR $\left(200 \mathrm{MHz}, \mathrm{CD}_{3} \mathrm{OD}\right)$ spectrum of compound 9.

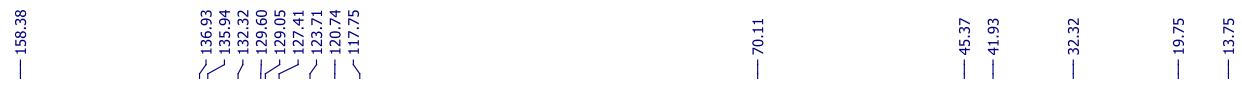<smiles>CCCCCOc1ccc2cc(S(=O)(=O)NCCN)ccc2c1-c1c(OCCCC)ccc2cc(S(=O)(=O)NCCN)ccc12</smiles>

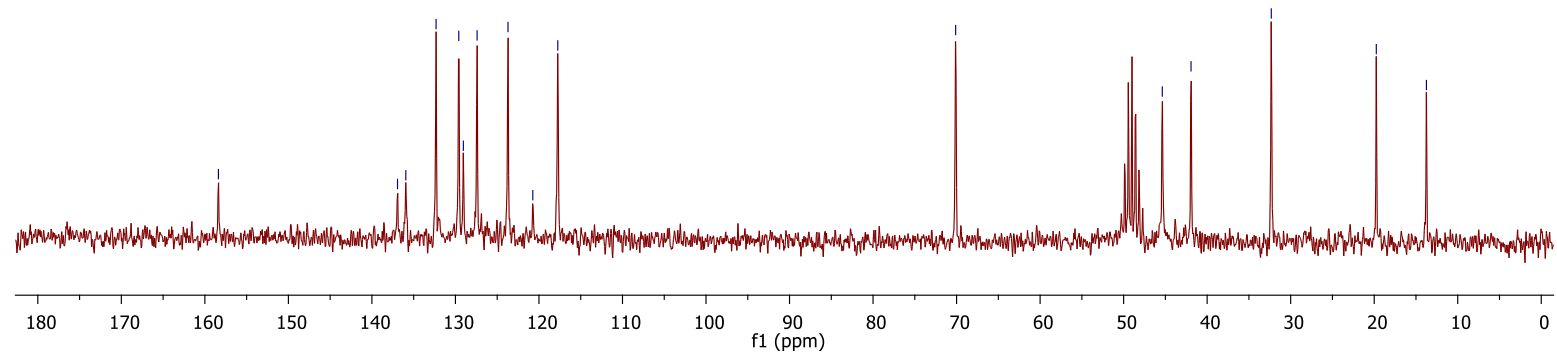

Figure S8. ${ }^{13} \mathrm{C}$ NMR $\left(50 \mathrm{MHz}, \mathrm{CD}_{3} \mathrm{OD}\right)$ spectrum of compound 9. 

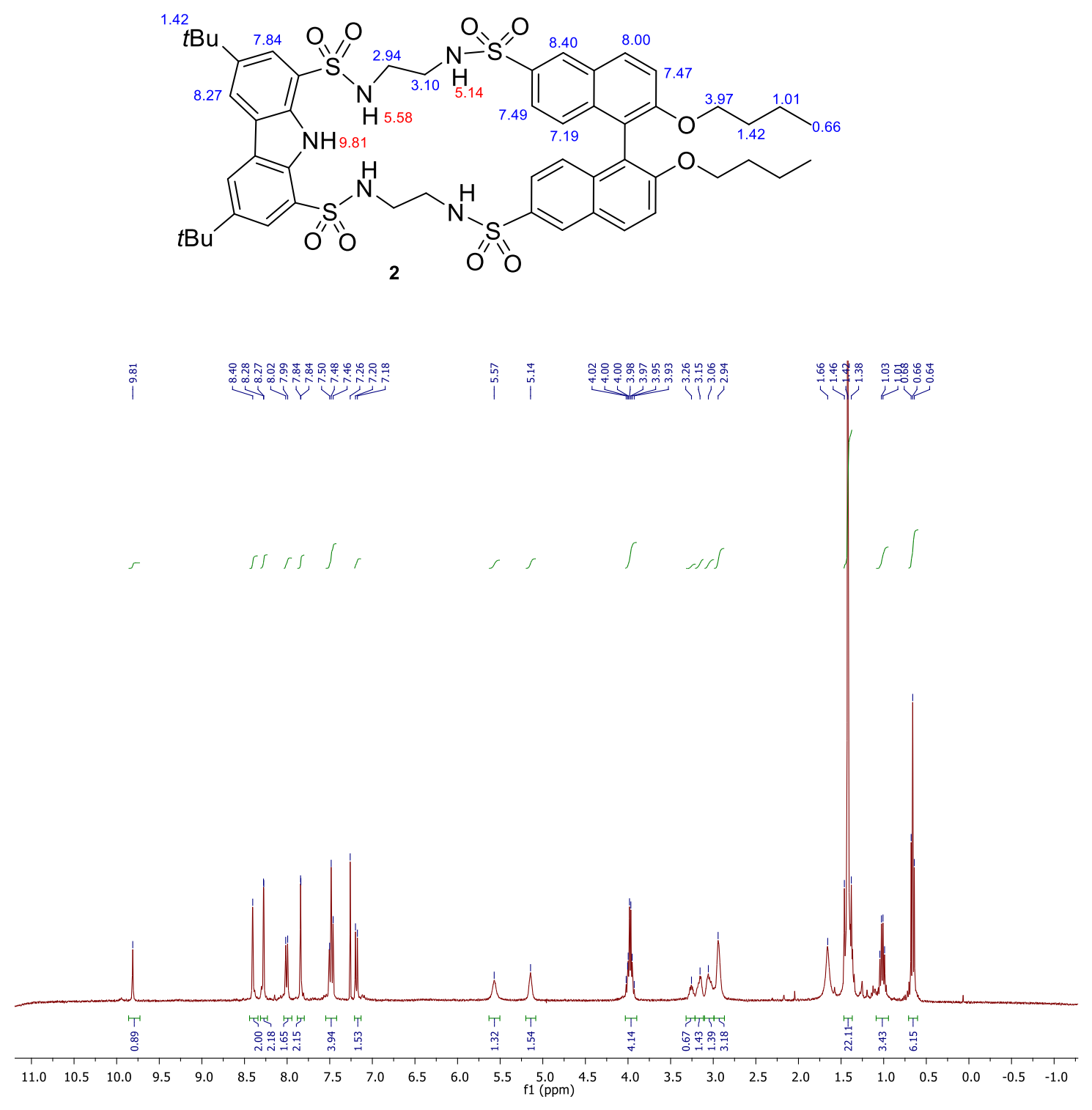

Figure S9. ${ }^{1} \mathrm{H}$ NMR $\left(400 \mathrm{MHz}, \mathrm{CDCl}_{3}\right)$ spectrum of compound 2. 

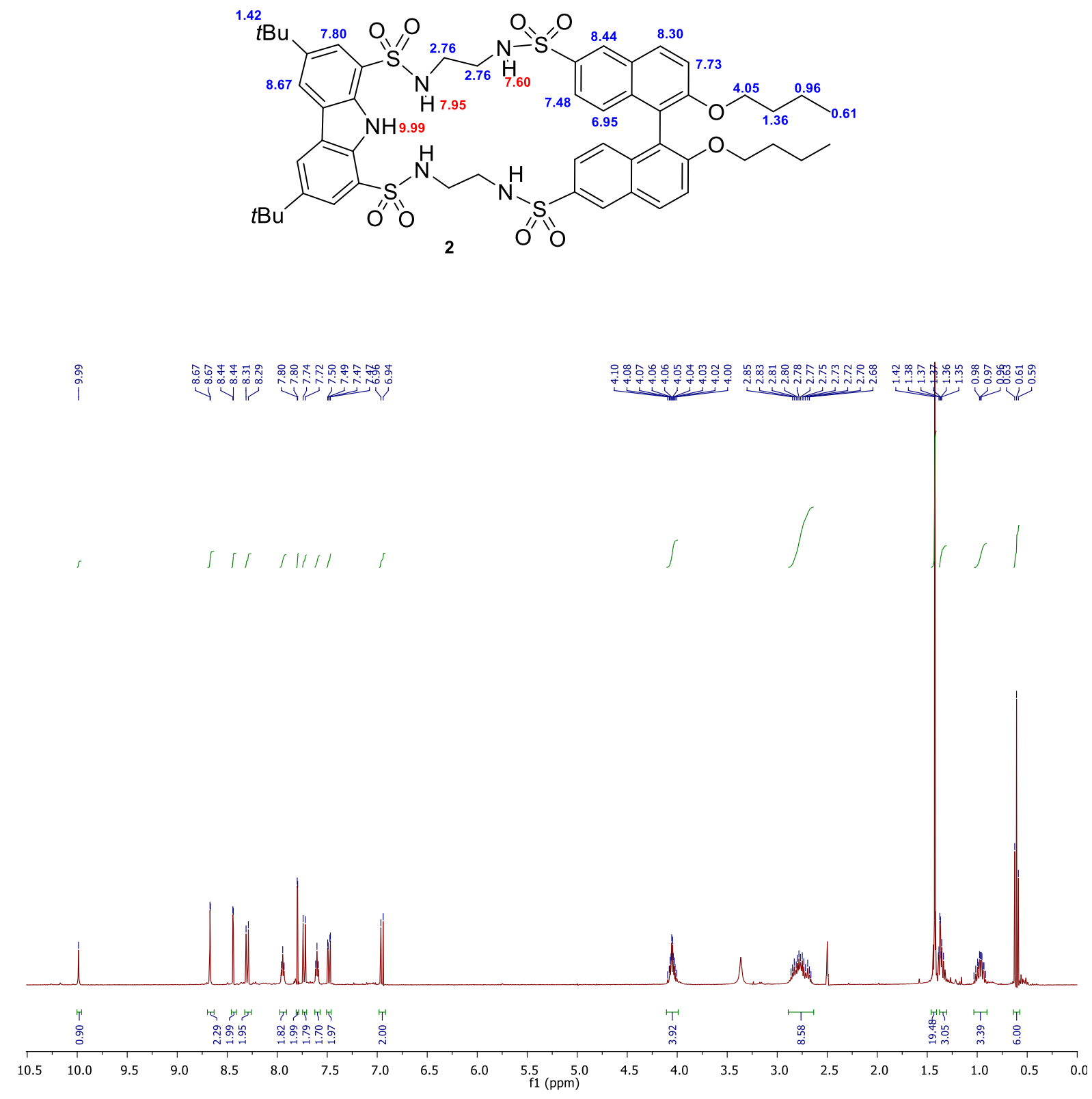

Figure S10. ${ }^{1} \mathrm{H}$ NMR $\left(400 \mathrm{MHz}, \mathrm{DMSO}-d_{6}\right)$ spectrum of compound 2. 

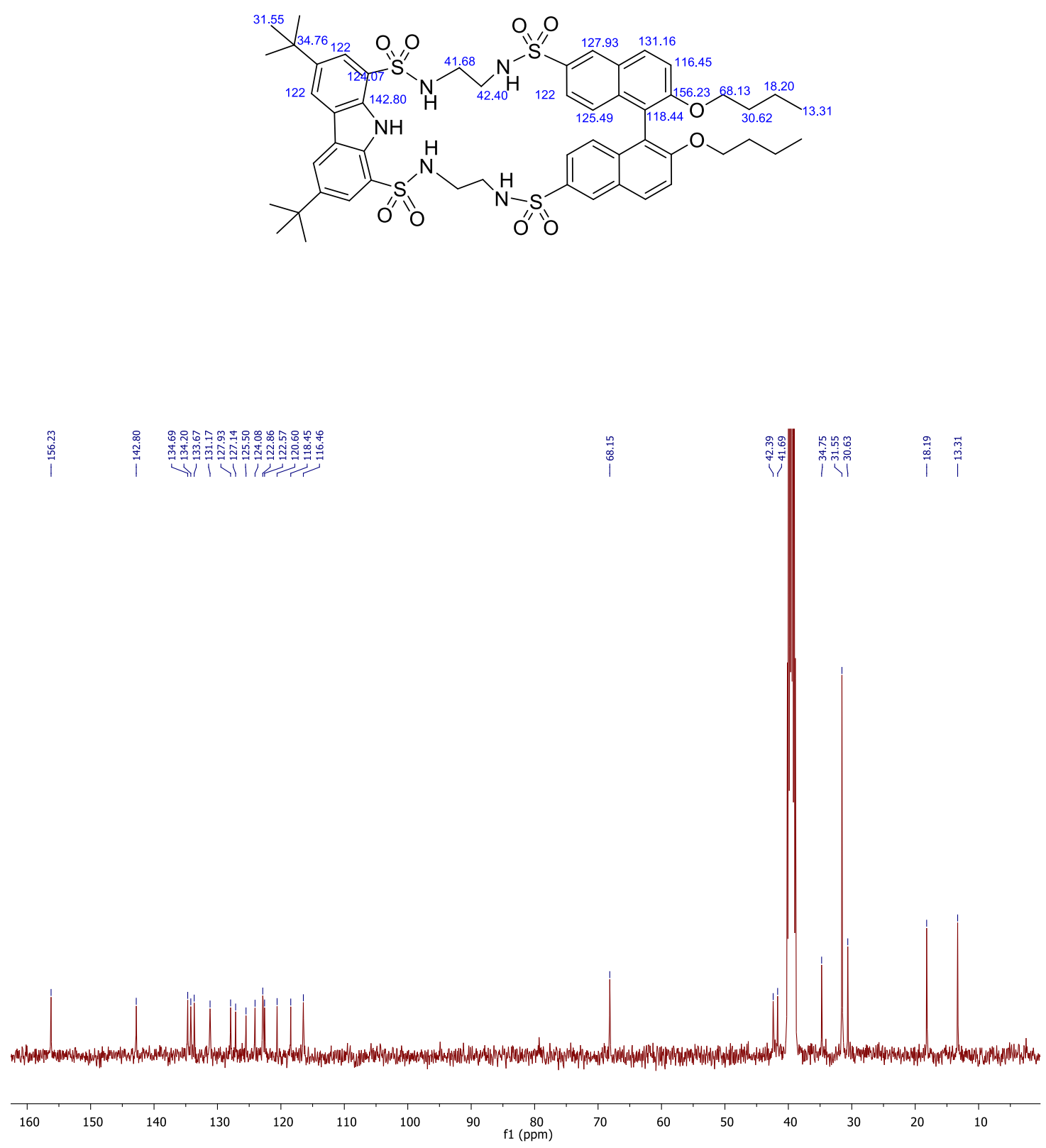

Figure S11. ${ }^{13} \mathrm{C}$ NMR $\left(100 \mathrm{MHz}, \mathrm{DMSO}-d_{6}\right)$ spectrum of compound 2. 

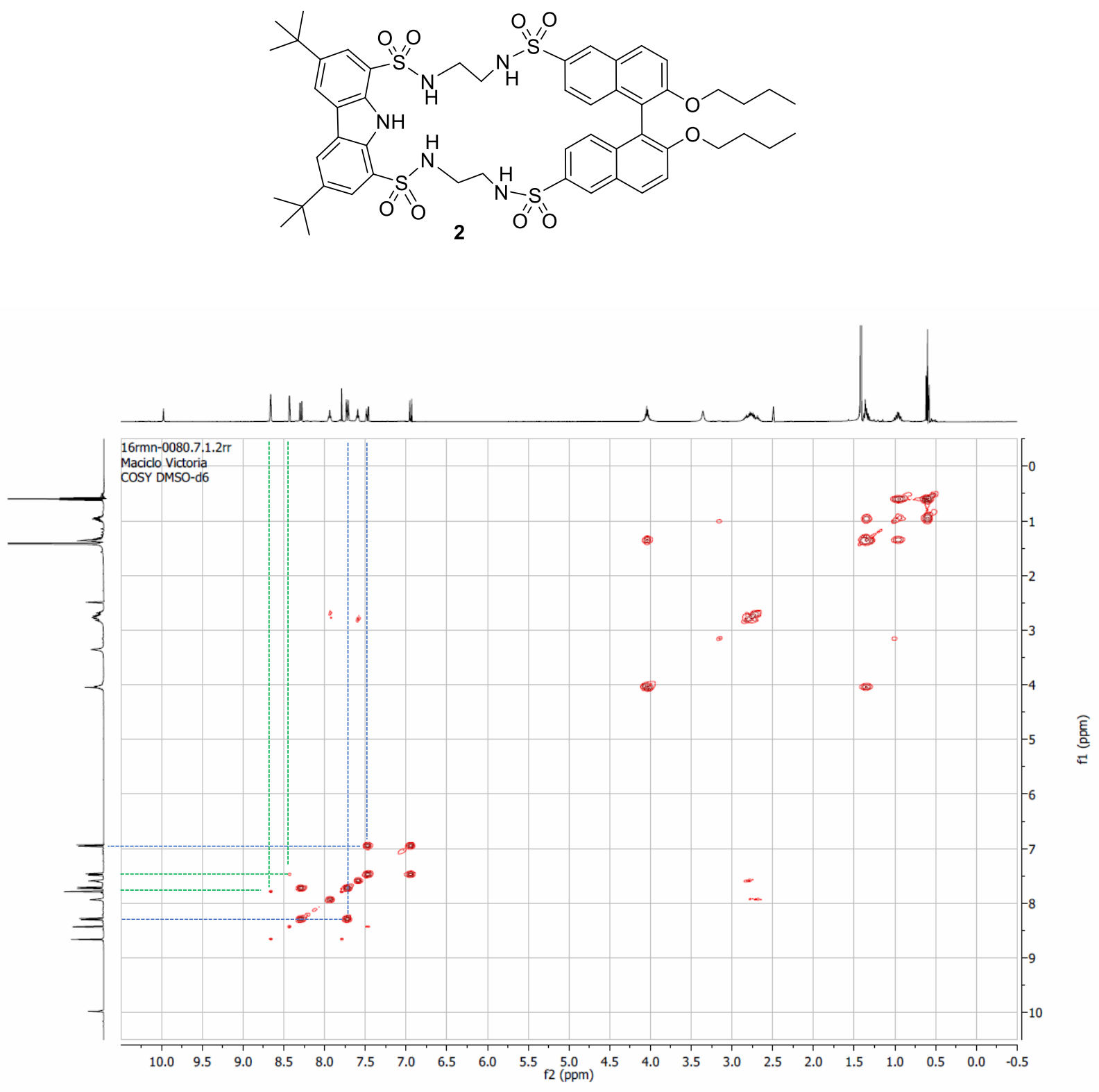

Figure S12. COSY (400MHz, DMSO- $\left.d_{6}\right)$ spectrum of compound 2. 

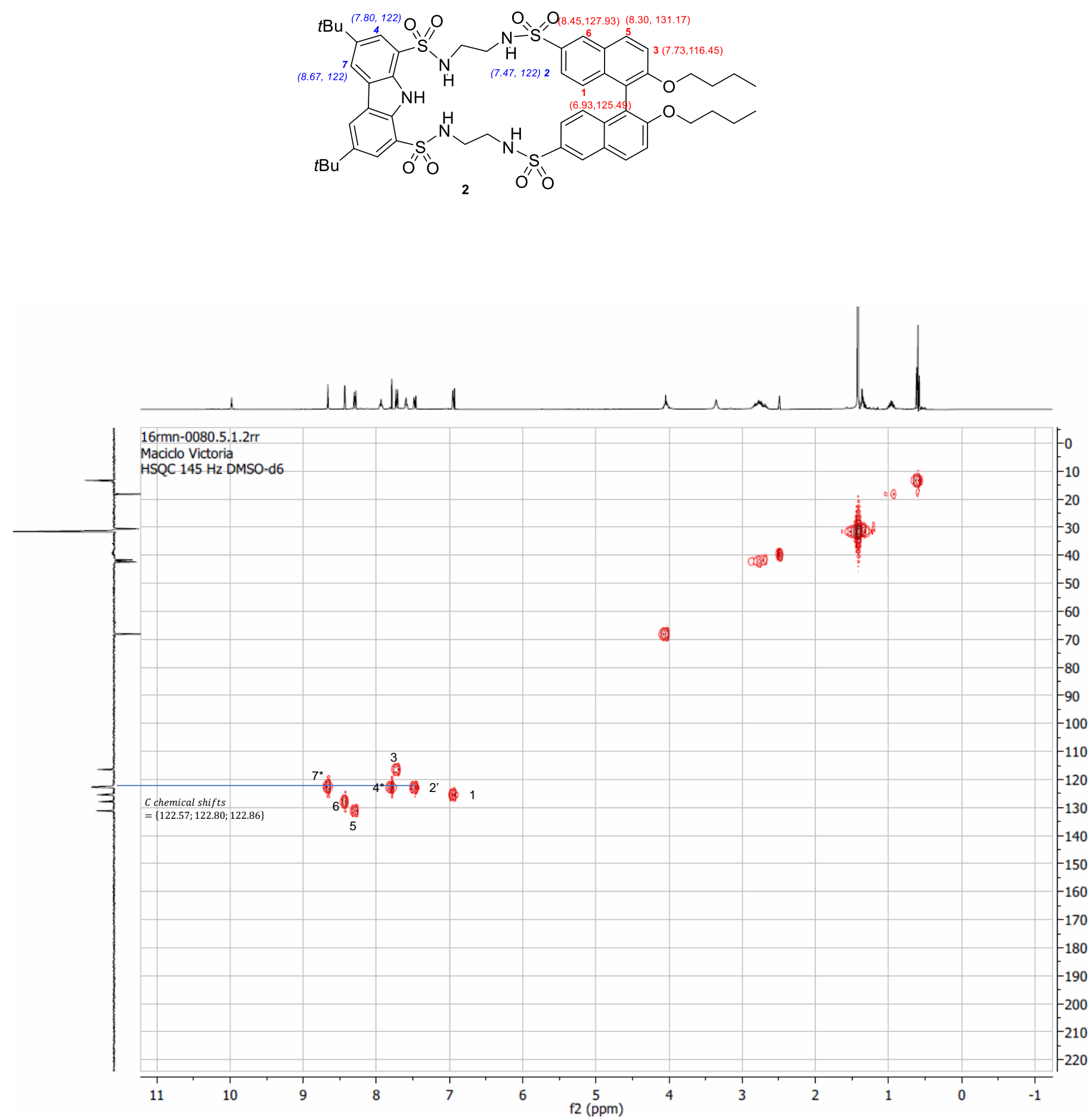

Figure S13. HSQC (DMSO- $d_{6}$ ) spectrum of compound 2. Main correlations corresponding to aromatic protons are numbered and shown on the macrocycle structure. Correlations marked with $*$ cannot be unambiguously assigned. 

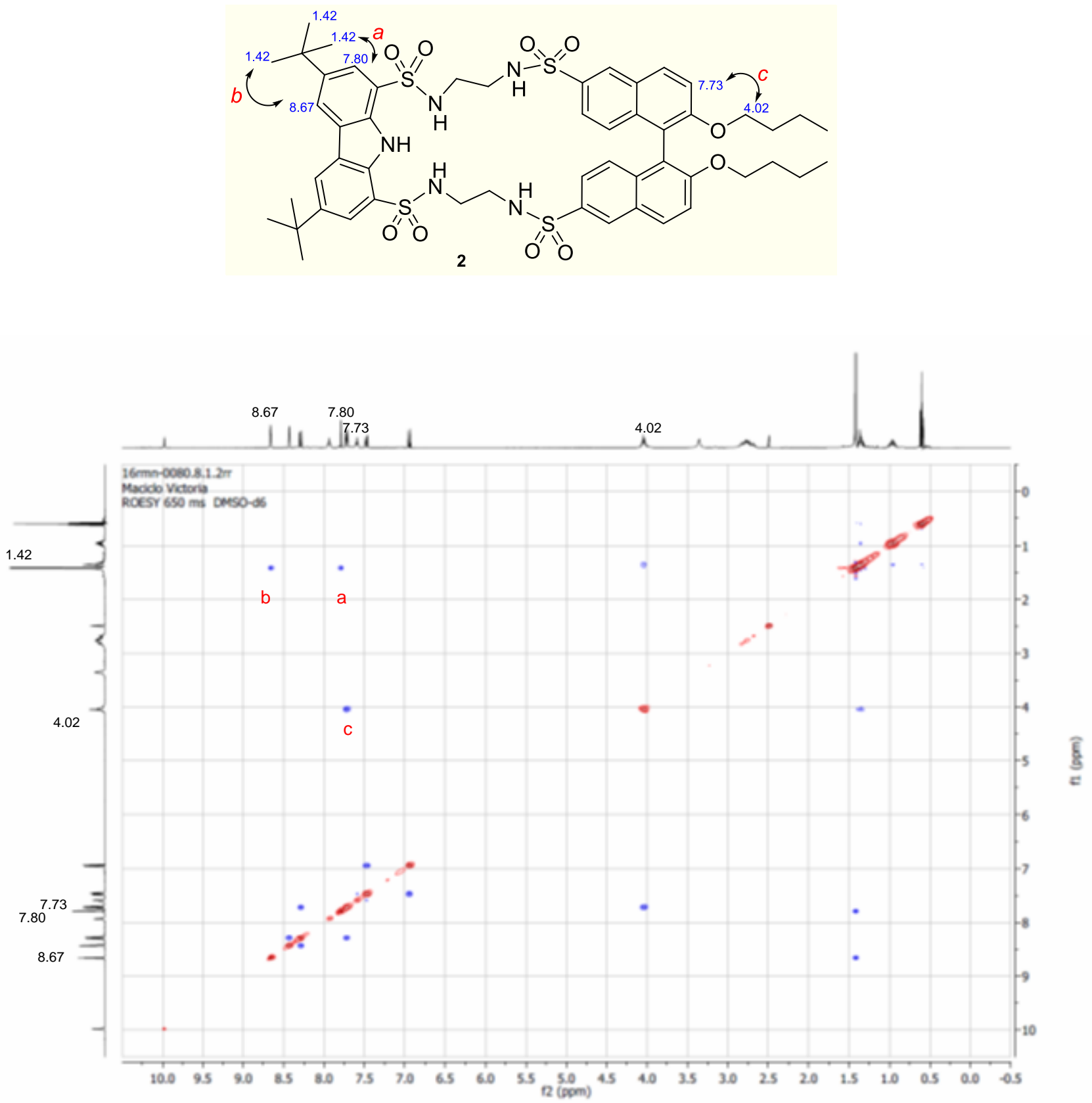

Figure S14. ROESY (DMSO- $d_{6}$ ) spectrum of compound 2. 

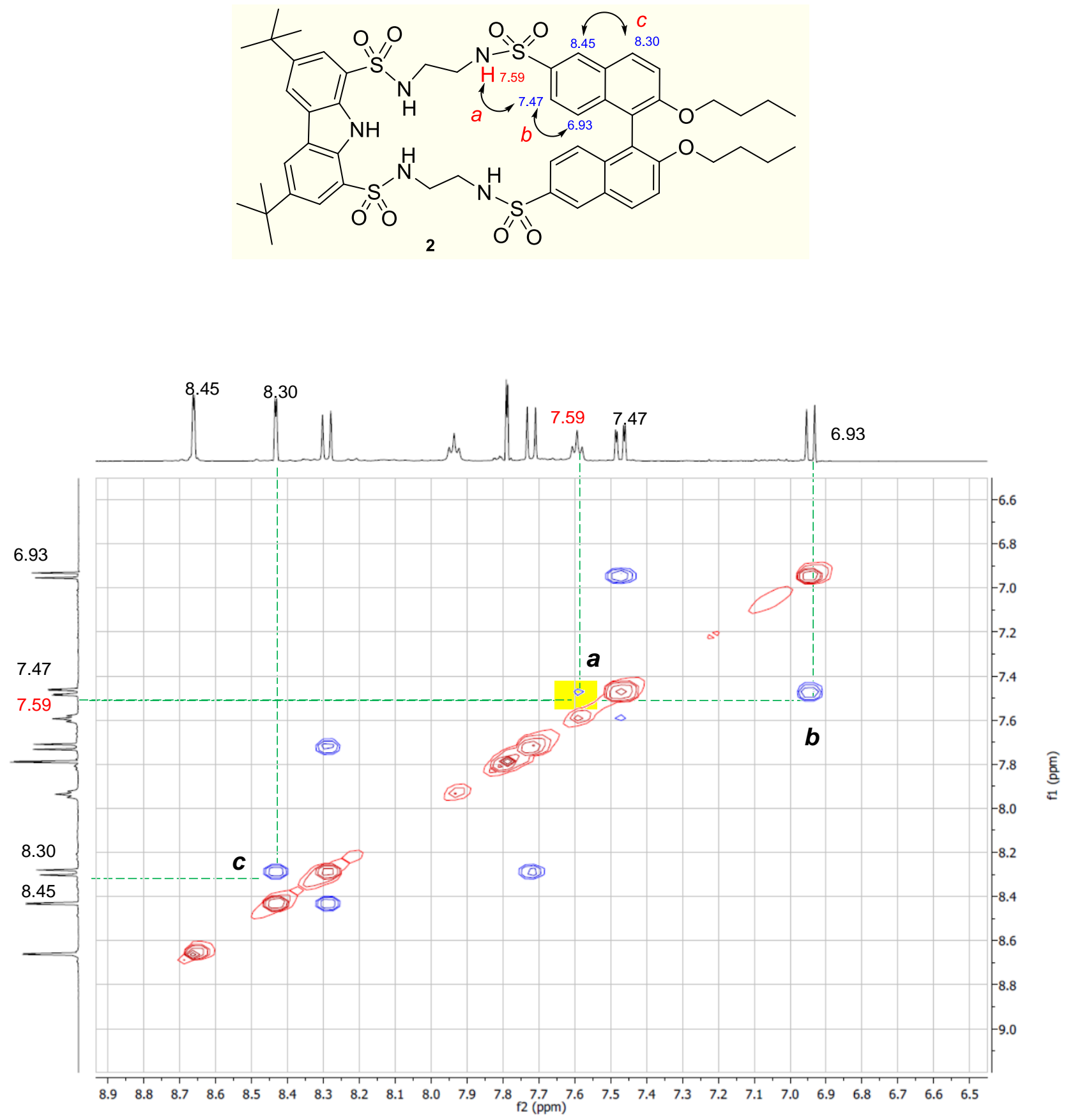

Figure S15. ROESY region (6.5-8.9 ppm, DMSO- $d_{6}$ ) spectrum of compound 2. 

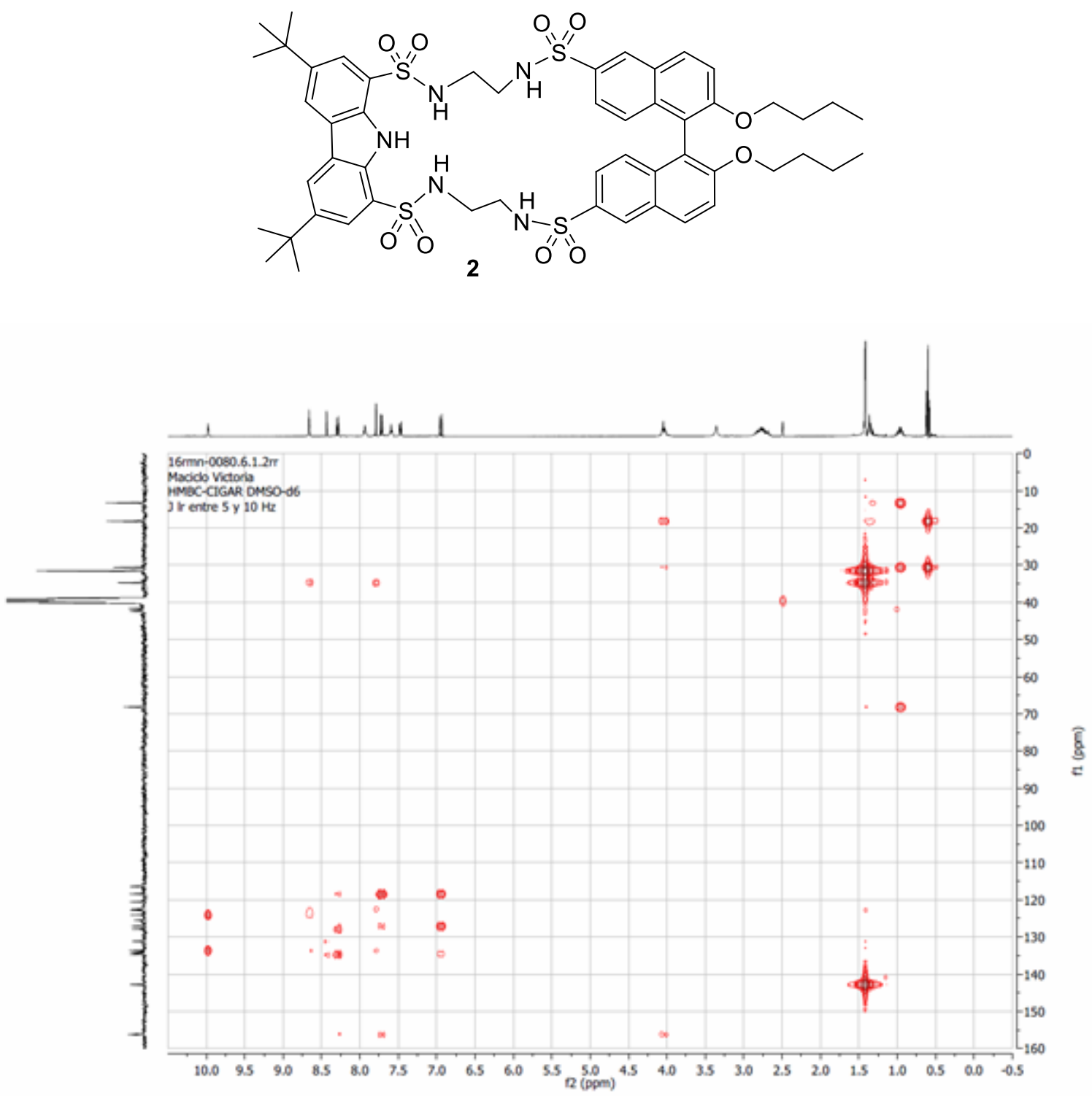

Figure S16. HMBC-CIGAR (DMSO- $d_{6}$ ) spectrum of compound 2. 

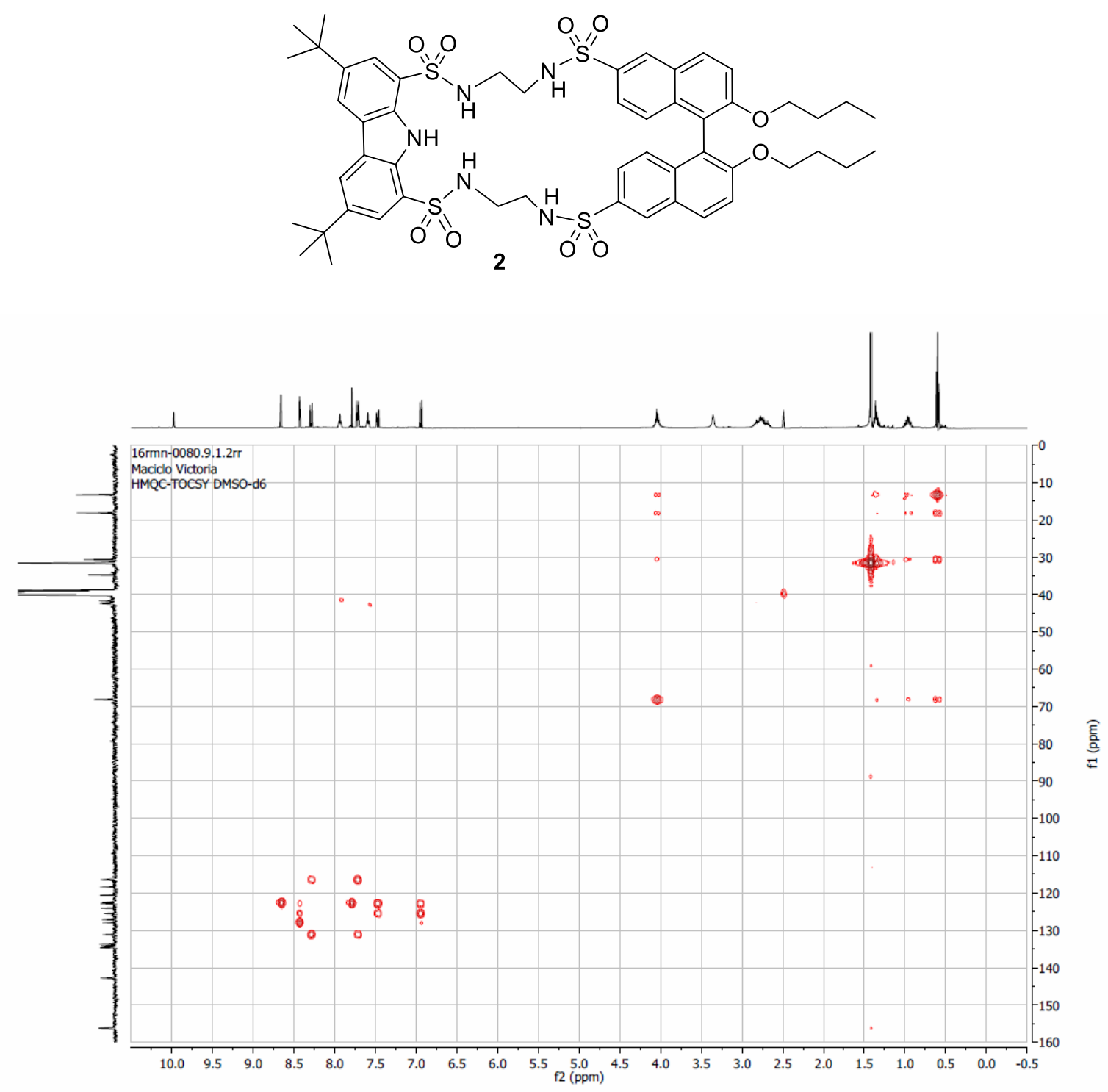

Figure S17. HMQC-TOCSY (DMSO- $d_{6}$ ) spectrum of compound 2. 

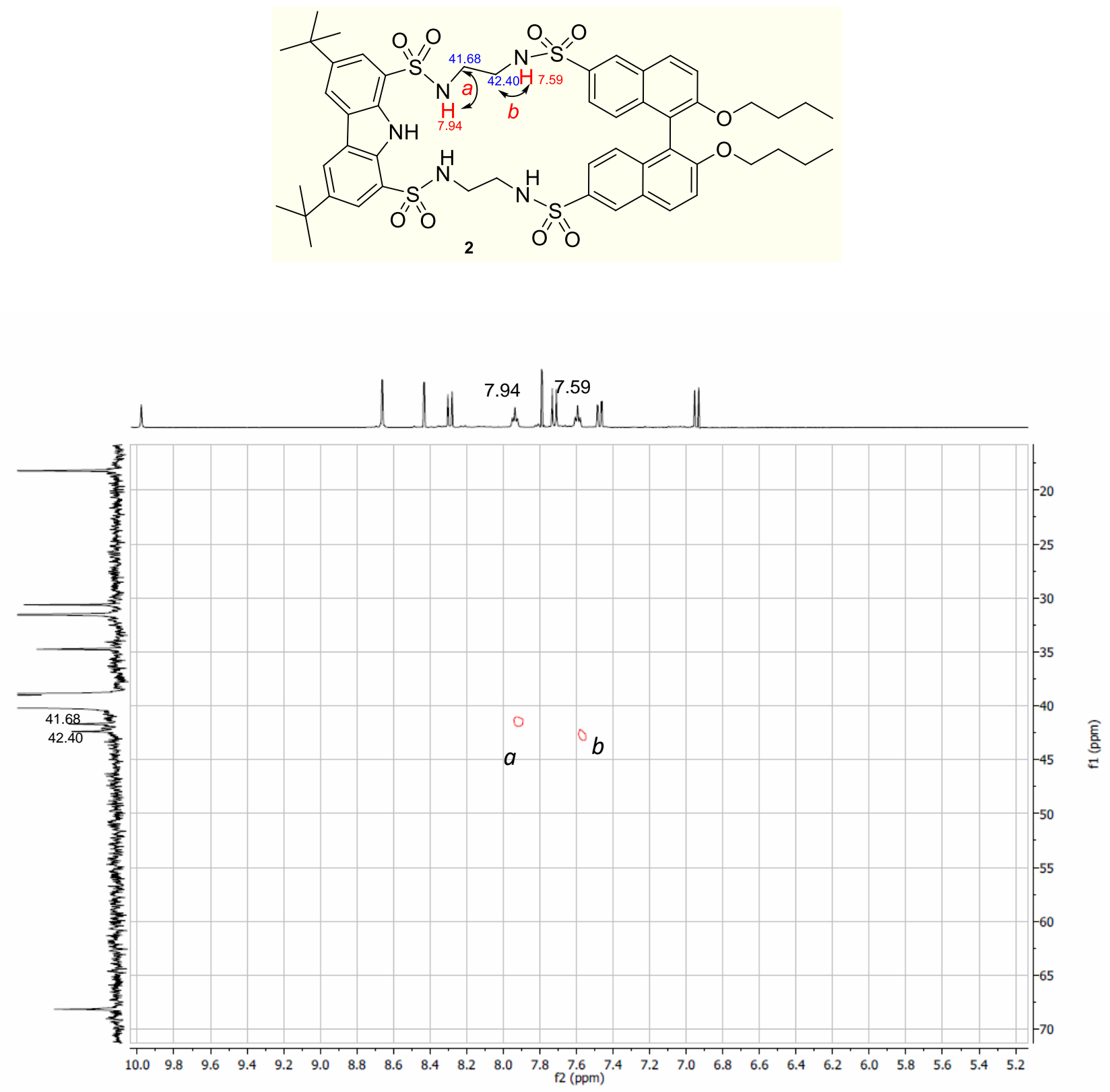

Figure S18. HMQC-TOCSY region (DMSO- $d_{6}$ ) spectrum of compound 2. 
GENERAL PROCEDURES FOR NMR TITRATIONS.

Measurement of binding constants by absolute ${ }^{1} \mathbf{H}$ NMR titrations. A typical procedure for NMR titrations is described. A solution of receptor $2(2 \mathrm{mM}, 2 \mathrm{~mL})$ in $\mathrm{CDCl}_{3}$ was prepared and a volume of $500 \mu \mathrm{L}$ was added to a standard NMR tube. The ${ }^{1} \mathrm{H}$ NMR spectrum of this sample was then collected at $298 \mathrm{~K}$. A solution of the tetrabutylammonium salt $(0.01 \mathrm{M})$ was prepared by dissolving the exact amount of the salt in the remaining solution $(1.5 \mathrm{~mL})$ of receptor 2 . Aliquots of this solution were then added to the NMR tube, mixing well after each addition and recording the corresponding ${ }^{1} \mathrm{H}$ NMR spectra. The concentration of receptor $\mathbf{2}$ was kept constant during the titration as the anion solution also contained receptor 2 at its initial concentration. The chemical shifts of selected protons were analyzed and plotted against the ratio of concentrations [Guest]/[Host]. $\mathrm{K}_{\mathrm{a}}$ values were calculated using a Monte Carlo nonlinear curve-fitting method.

Measurement of binding constants by competitive ${ }^{1} \mathbf{H}$ NMR titrations. For competitive titrations, a solution of both receptors in $\mathrm{CDCl}_{3}(2 \mathrm{~mL})$ was prepared with similar concentrations of the receptors $[1]=[2]=10^{-2} \mathrm{M}$. A volume of $500 \mu \mathrm{L}$ of this solution was added to a standard NMR tube and the ${ }^{1} \mathrm{H}$ NMR spectrum of the sample was collected at $298 \mathrm{~K}$. A solution of the tetrabutylammonium salt $(0.025$ M) was prepared by dissolving the exact amount of the salt in the remaining solution $(1.5 \mathrm{~mL})$ of the receptors. Aliquots of the solution containing the salt were then added to the NMR tube, mixing well after each addition and recording the corresponding ${ }^{1} \mathrm{H}$ NMR spectra. The chemical shifts of selected protons from both receptors were analyzed and plotted against each other. The relative association constant was calculated using a Monte Carlo nonlinear curve-fitting method. 


\section{SELECTED BINDING CURVES.}

Host: macrocycle 2

Guest: TBA acetate

$K_{\mathrm{a}}=2.8 \times 10^{5} \mathrm{M}^{-1}$
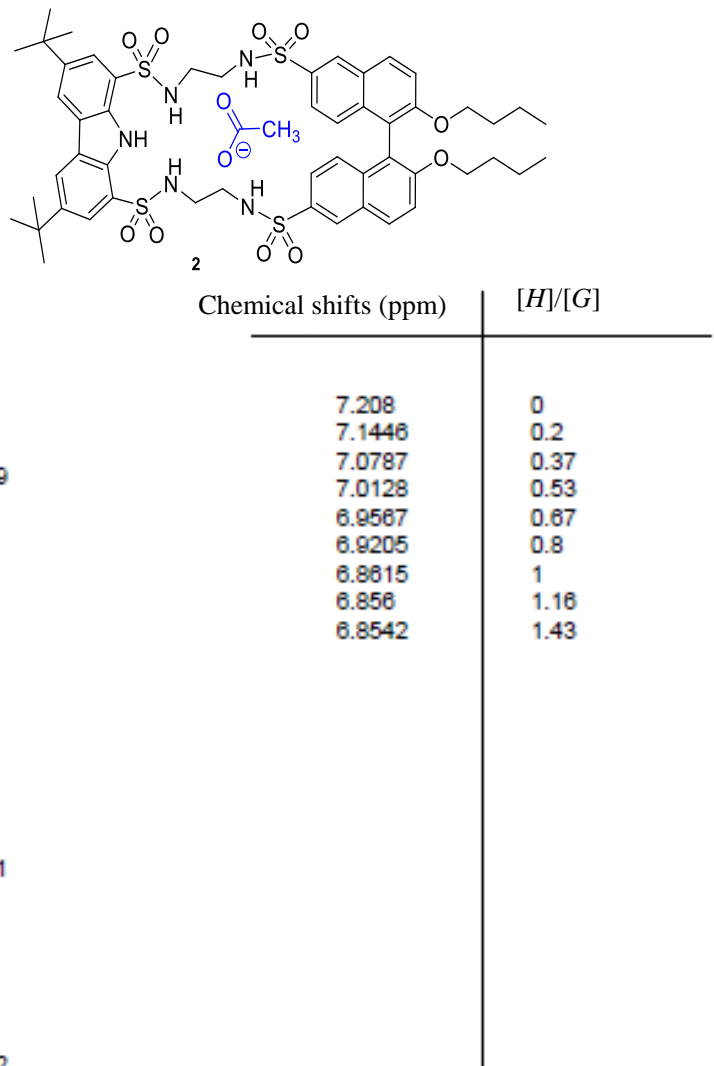

Figure S19. Binding isotherm for complexation between 2 and TBA acetate. 

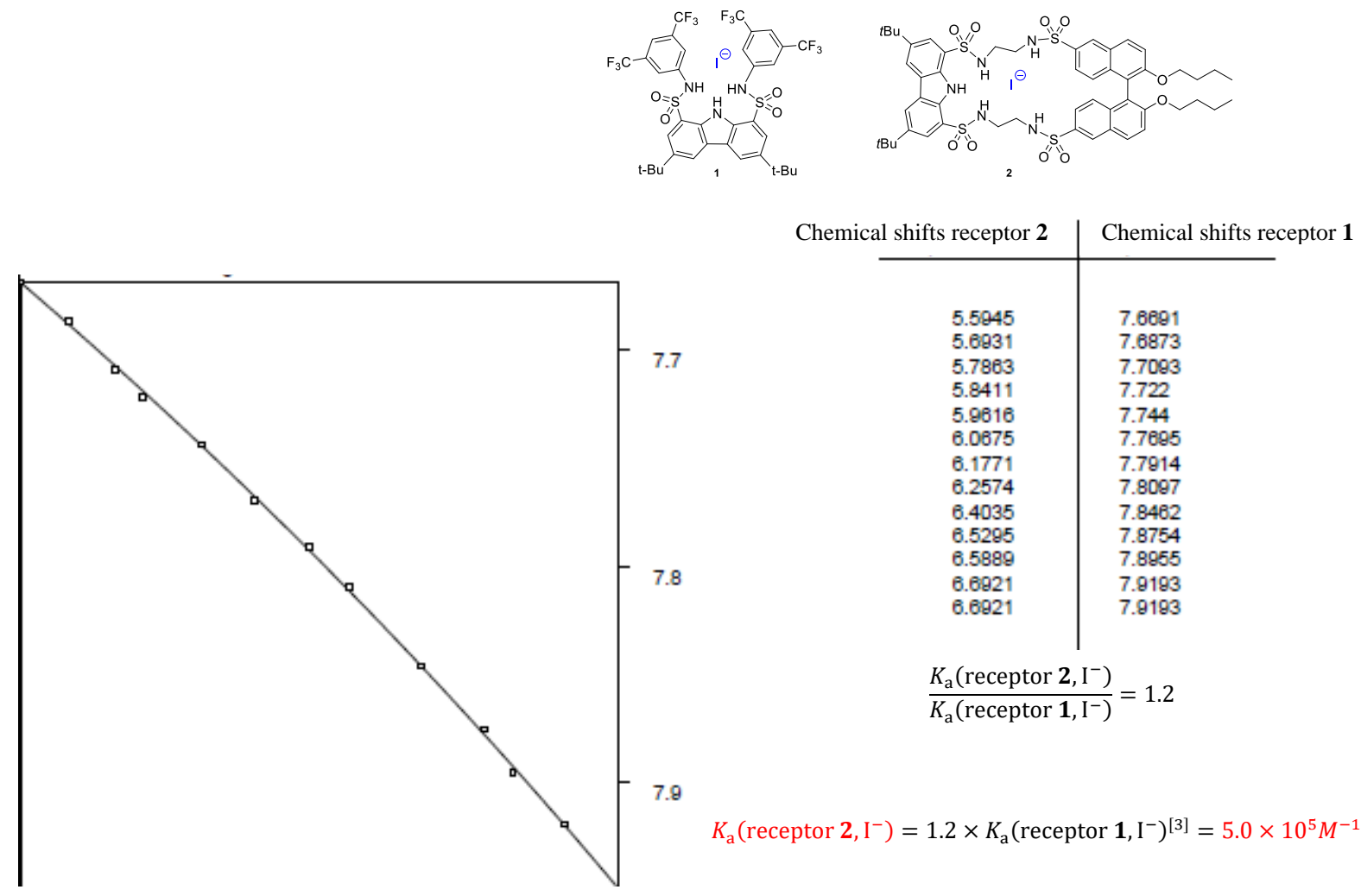

Figure S20. Binding isotherm for competitive titration between receptors $\mathbf{1}$ and $\mathbf{2}$ and TBA iodide. 

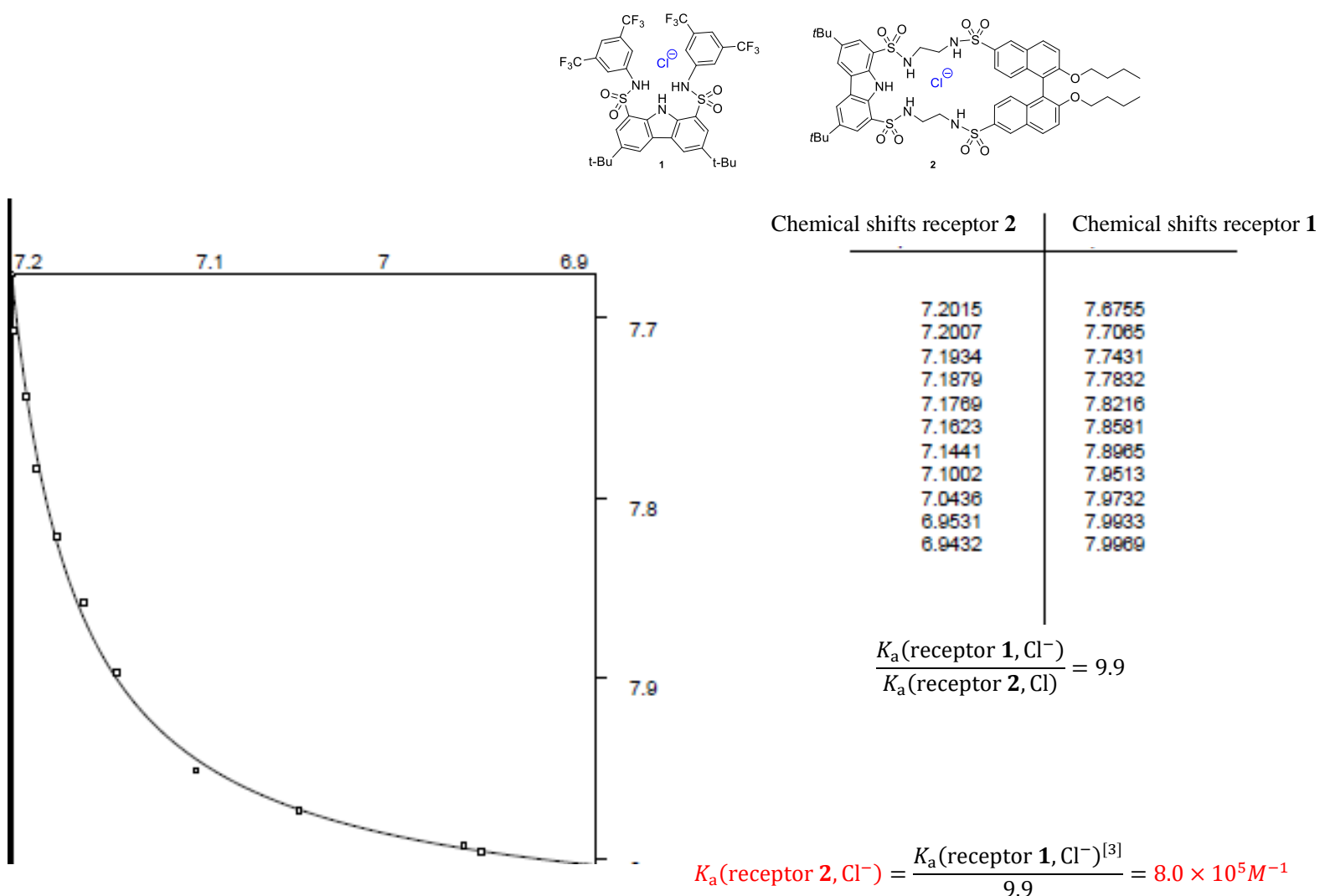

$K_{\mathrm{a}}\left(\right.$ receptor $\left.2, \mathrm{Cl}^{-}\right)=\frac{K_{\mathrm{a}}\left(\text { receptor } \mathbf{1}, \mathrm{Cl}^{-}\right)^{[3]}}{9.9}=8.0 \times 10^{5} \mathrm{M}^{-1}$

Figure S21. Binding isotherm for competitive titration between receptors $\mathbf{1}$ and $\mathbf{2}$ and TEA chloride 


\section{GENERAL PROCEDURE FOR AMINO ACID EXTRACTION. ${ }^{1} \mathrm{H}$ NMR SPECTRA}

In a typical liquid-liquid extraction experiment, the organic layer was prepared by dissolving together $24 \mathrm{mg}(22.9 \mathrm{mmol})$ of the macrocycle 2 and $14 \mathrm{mg}(53.0 \mathrm{mmol})$ of the 18 -crown- 6 ether in $2 \mathrm{~mL}$ of $\mathrm{CDCl}_{3}\left([2]=1.15 \times 10^{-2} \mathrm{M}\right.$; [crown ether] $\left.=2.65 \times 10^{-2} \mathrm{M}\right)$. A portion of this solution $(0.5 \mathrm{~mL})$ was added to $0.5 \mathrm{~mL}$ of an aqueous saturated solution of the corresponding amino acid. The mixture was stirred for 15 minutes, centrifugated and the ${ }^{1} \mathrm{H}$ NMR spectrum of the organic layer was obtained. The extraction efficiency (in terms of extracted equivalents of amino acids) was determined by integration of the ${ }^{1} \mathrm{H}$ NMR signals.
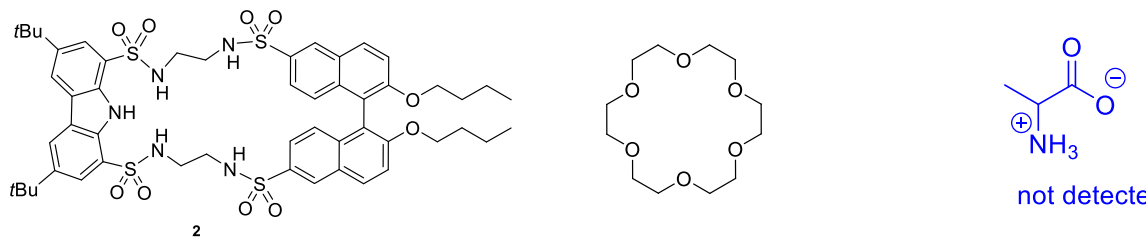

not detected

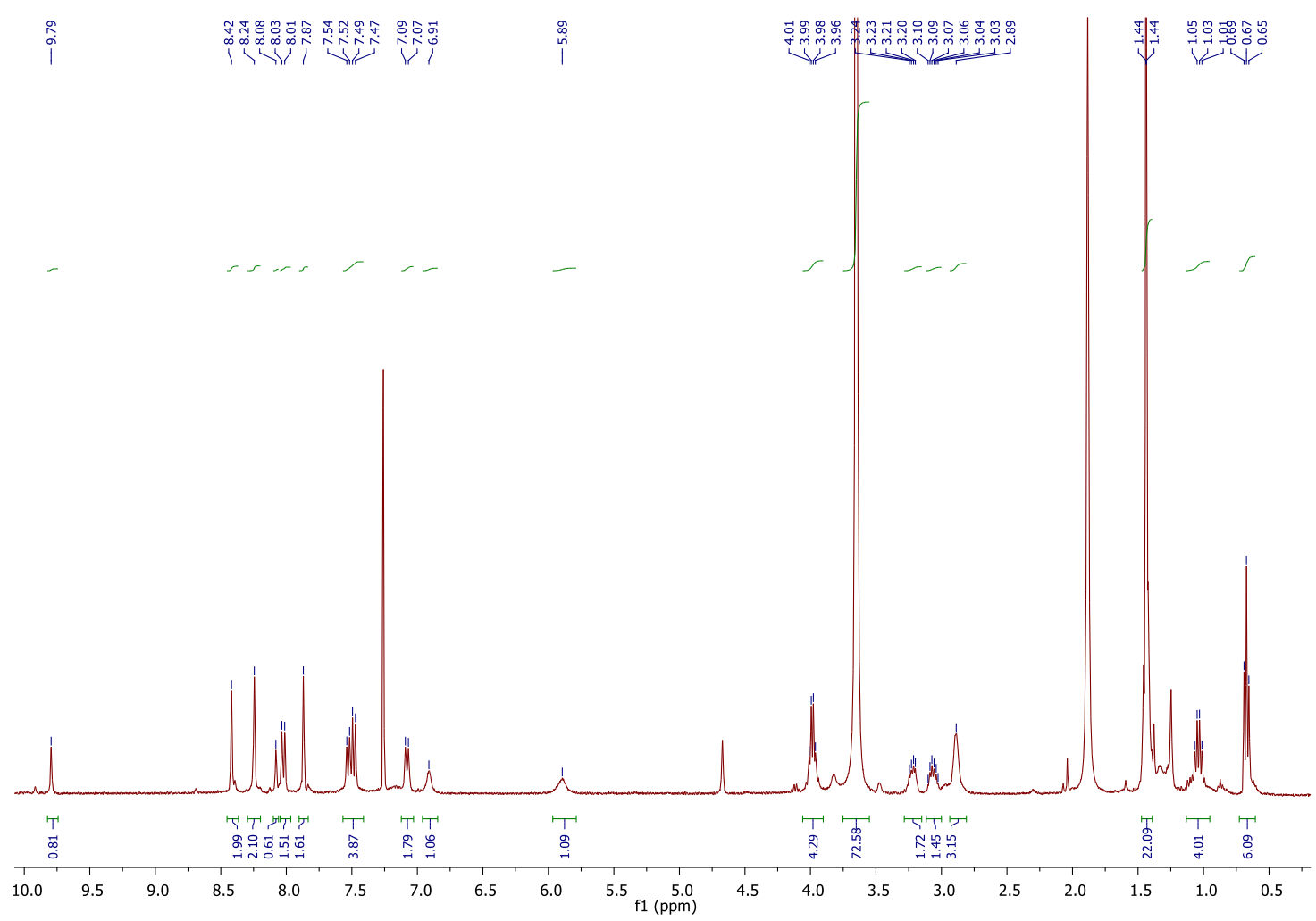

Figure S22. ${ }^{1} \mathrm{H}$ NMR spectrum of the $\mathrm{CDCl}_{3}$ phase containing macrocycle 2 and 18 -crown-6 ether after extraction of racemic alanine. 

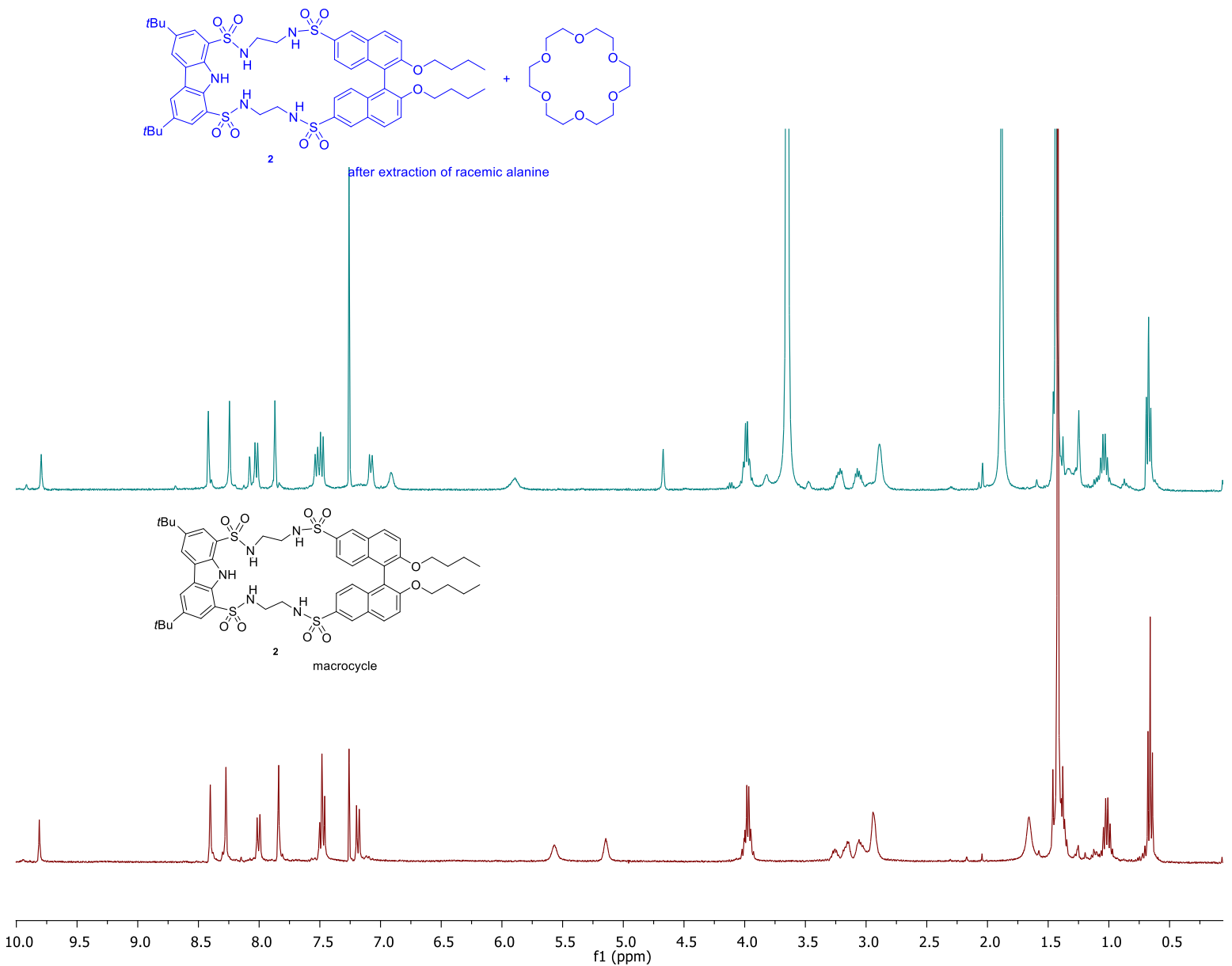

Figure S23. Comparison of the ${ }^{1} \mathrm{H}$ NMR spectra of macrocycle 2 (bottom) and the combination of macrocycle 2 with 18-crown-6 ether after extraction of racemic alanine (top). 

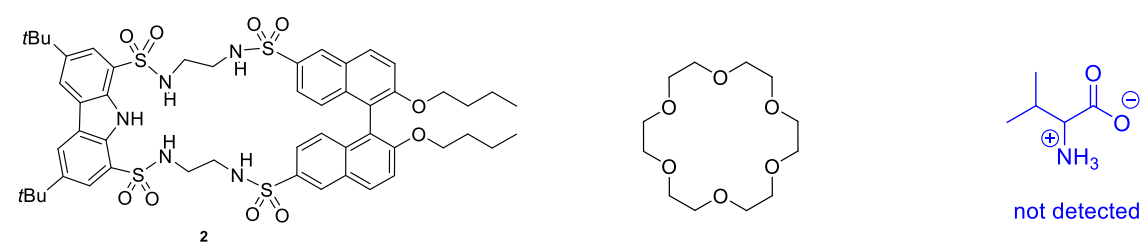

not detected

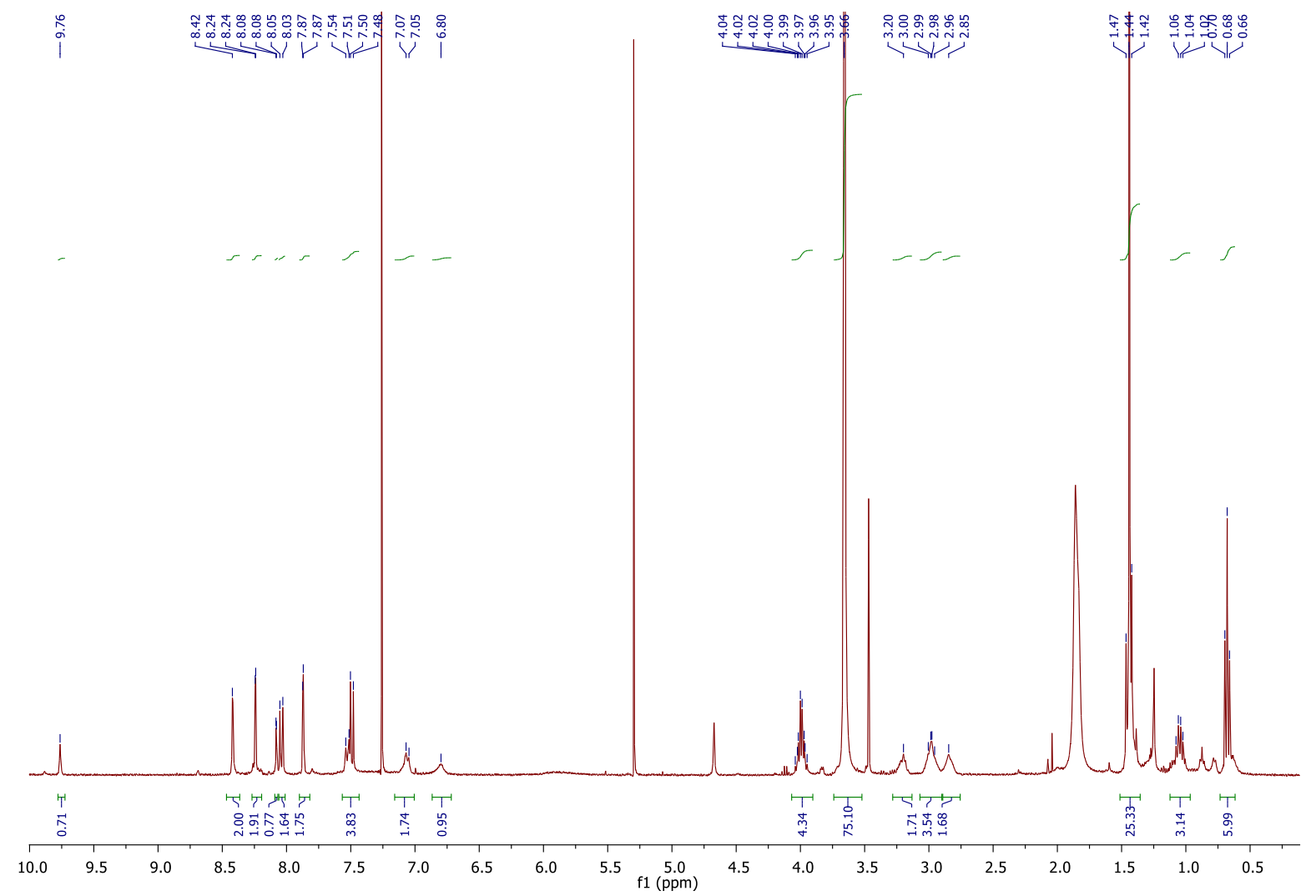

Figure S24. ${ }^{1} \mathrm{H}$ NMR spectrum of the $\mathrm{CDCl}_{3}$ phase containing macrocycle 2 and 18 -crown-6 ether after extraction of racemic valine. 

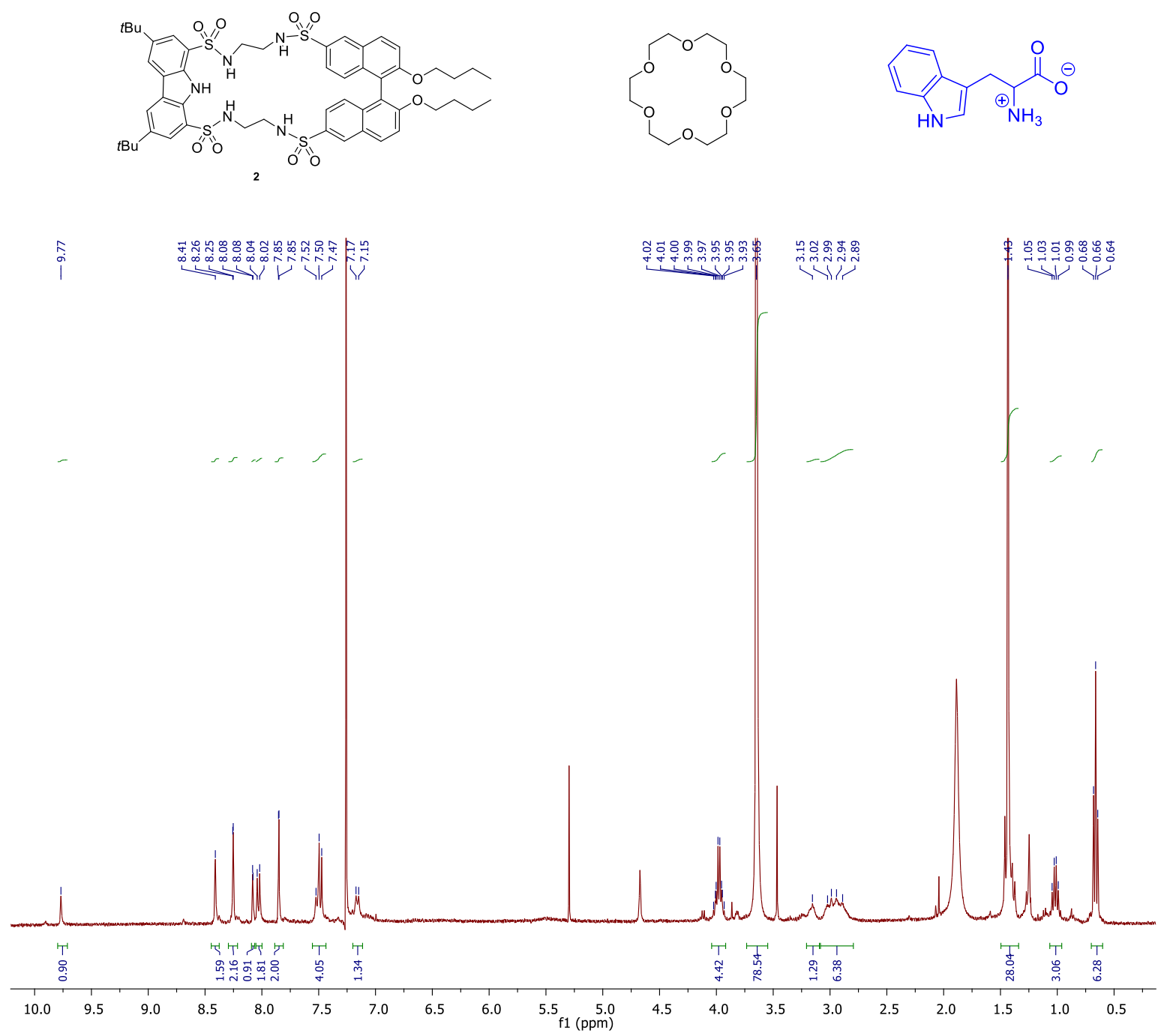

Figure S25. ${ }^{1} \mathrm{H}$ NMR spectrum of the $\mathrm{CDCl}_{3}$ phase containing macrocycle 2 and 18 -crown- 6 ether after extraction of racemic tryptophan. 


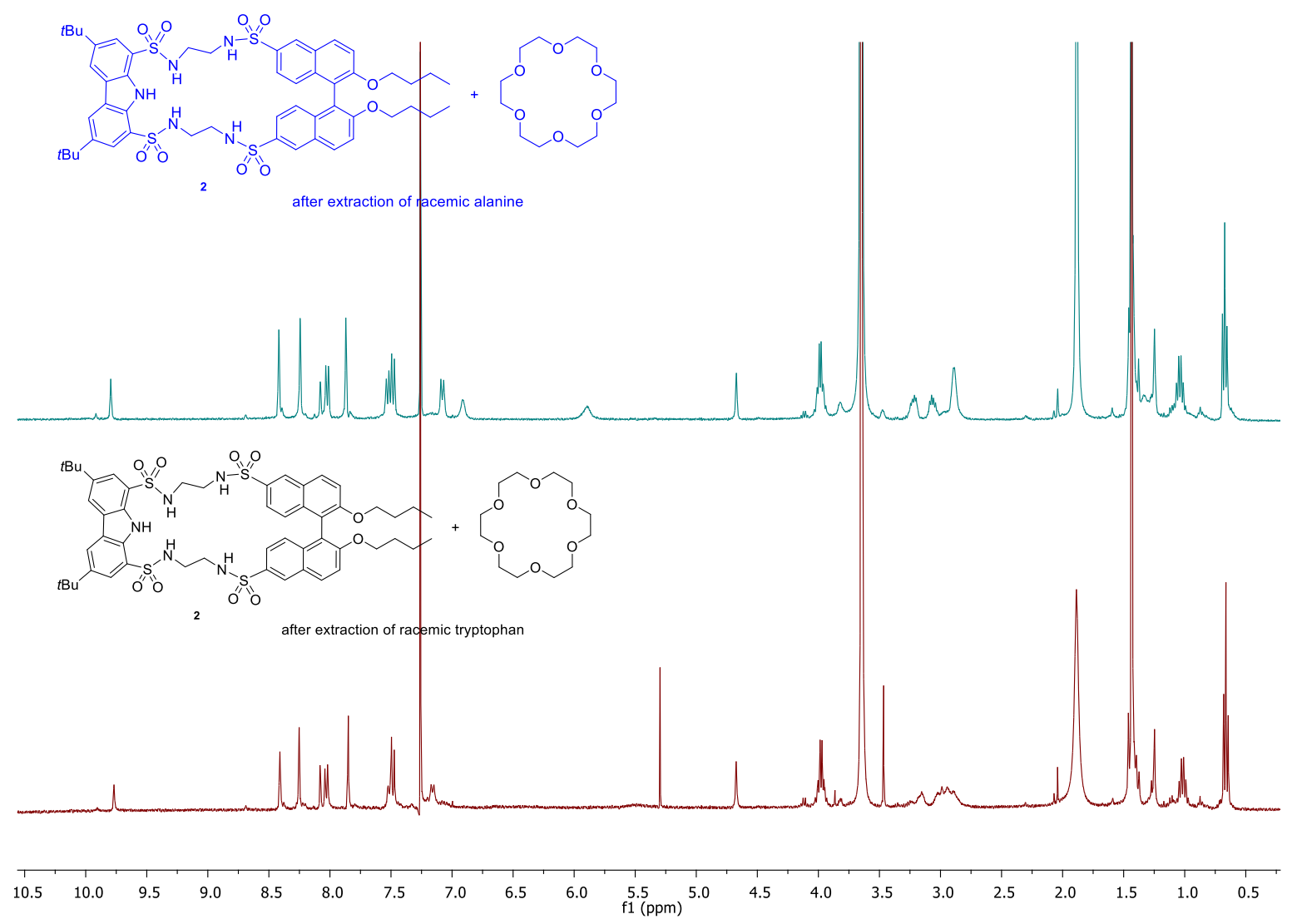

Figure S26. Comparison between the ${ }^{1} \mathrm{H}$ NMR spectra corresponding to the $\mathrm{CDCl}_{3}$ phase (already containing macrocycle 2 and 18-crown-6 ether) after extractions of racemic alanine (top) and racemic tryptophan (bottom). Both spectra are similar. 

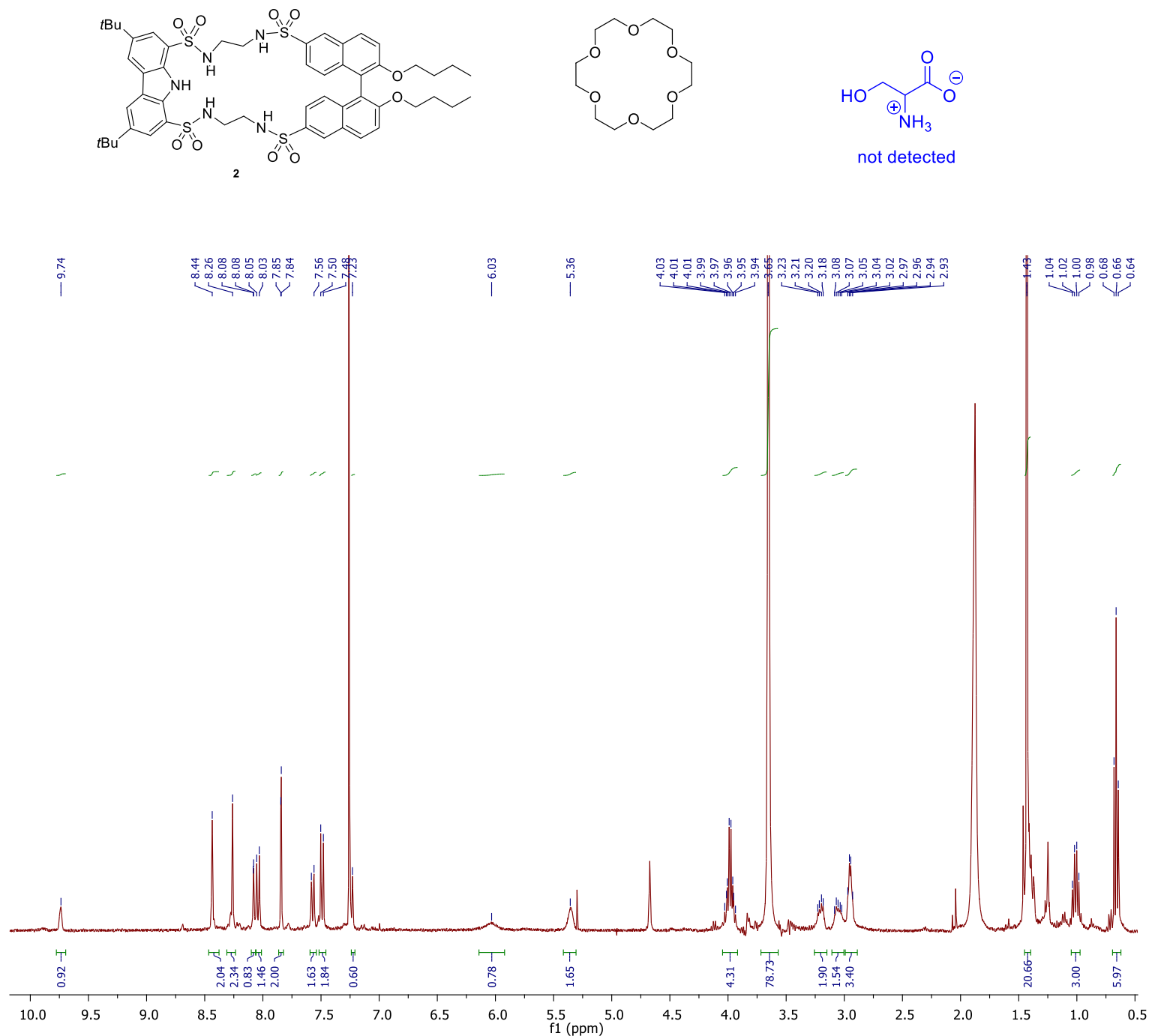

Figure S27. ${ }^{1} \mathrm{H}$ NMR spectrum of the $\mathrm{CDCl}_{3}$ phase containing macrocycle 2 and 18 -crown-6 ether after extraction of racemic serine 

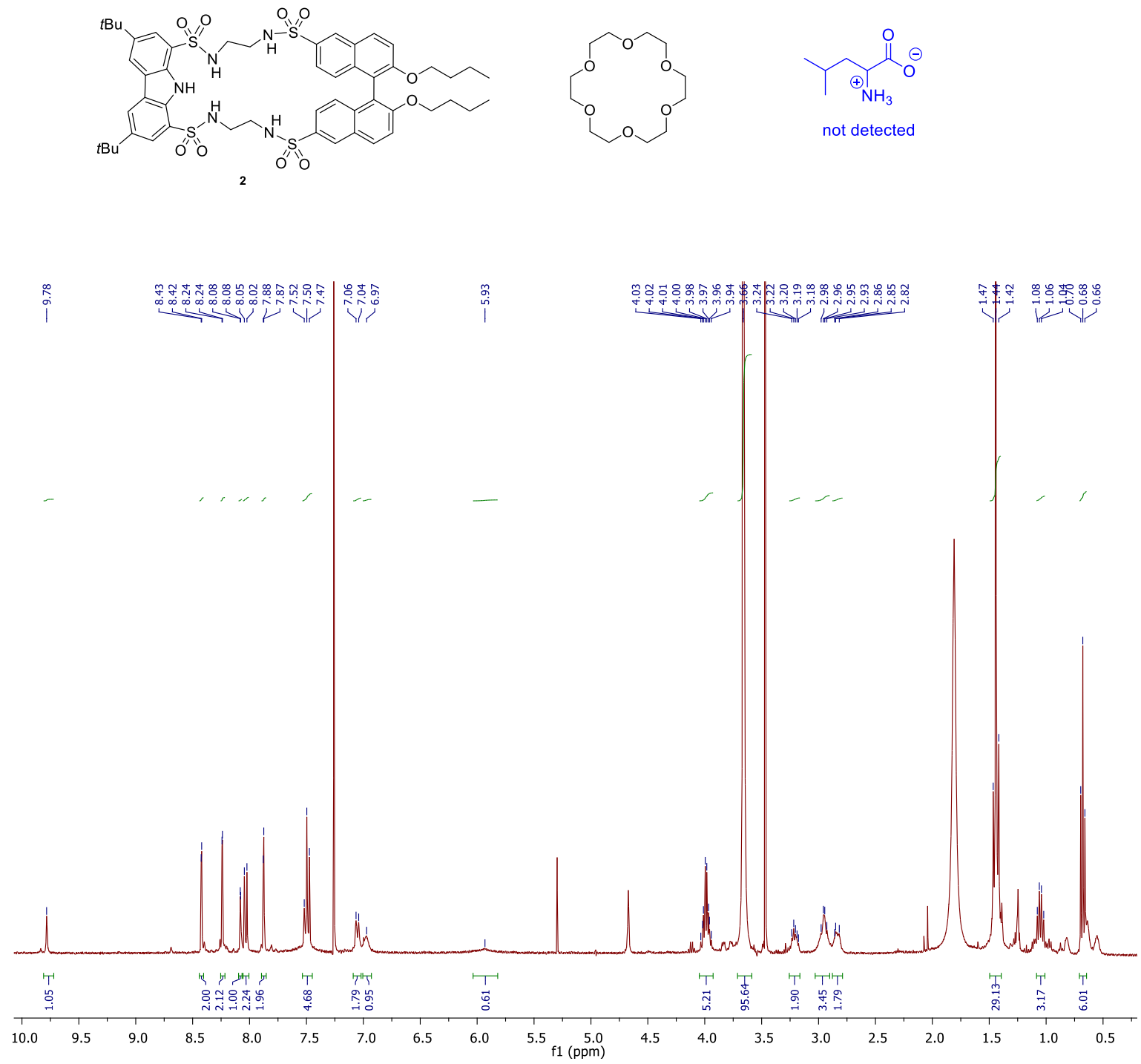

Figure S28. ${ }^{1} \mathrm{H}$ NMR spectrum of the $\mathrm{CDCl}_{3}$ phase containing macrocycle $\mathbf{2}$ and 18 -crown- 6 ether after extraction of racemic leucine. 

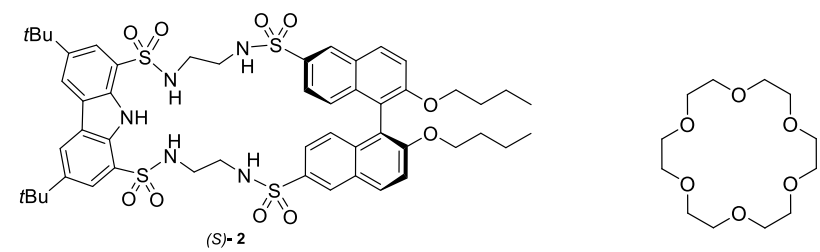<smiles>N[C@@H](Cc1ccccc1)C(=O)O</smiles>

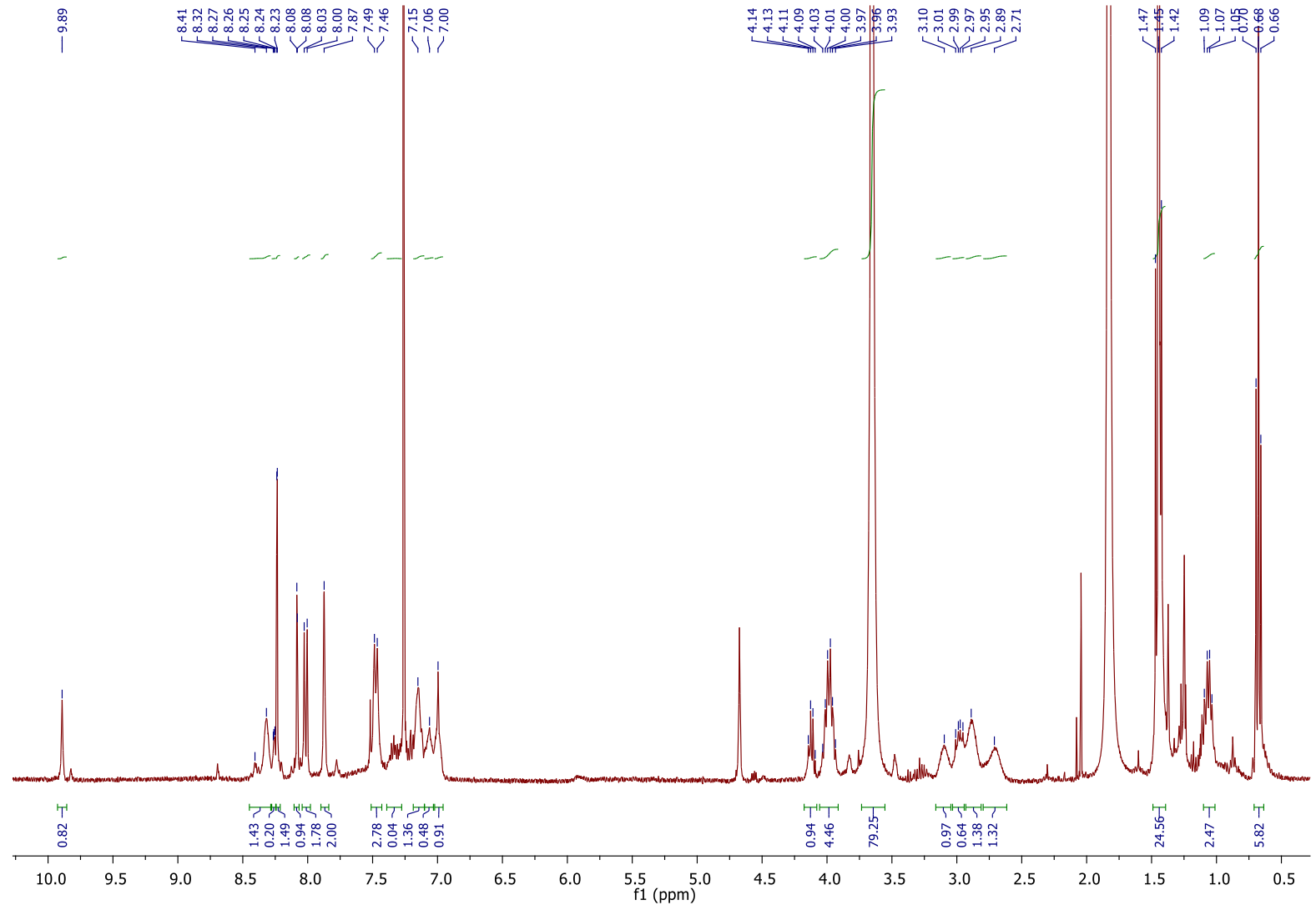

Figure S29. ${ }^{1} \mathrm{H}$ NMR spectrum of the $\mathrm{CDCl}_{3}$ phase containing macrocycle $(S)-2$ and 18 -crown-6 ether after extraction of D- phenylalanine. 

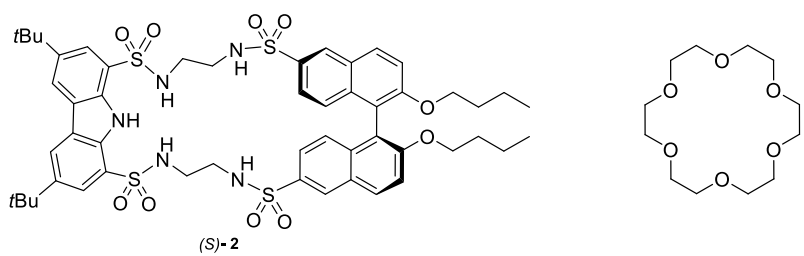<smiles>N[C@@H](Cc1ccccc1)C(=O)[O-]</smiles>

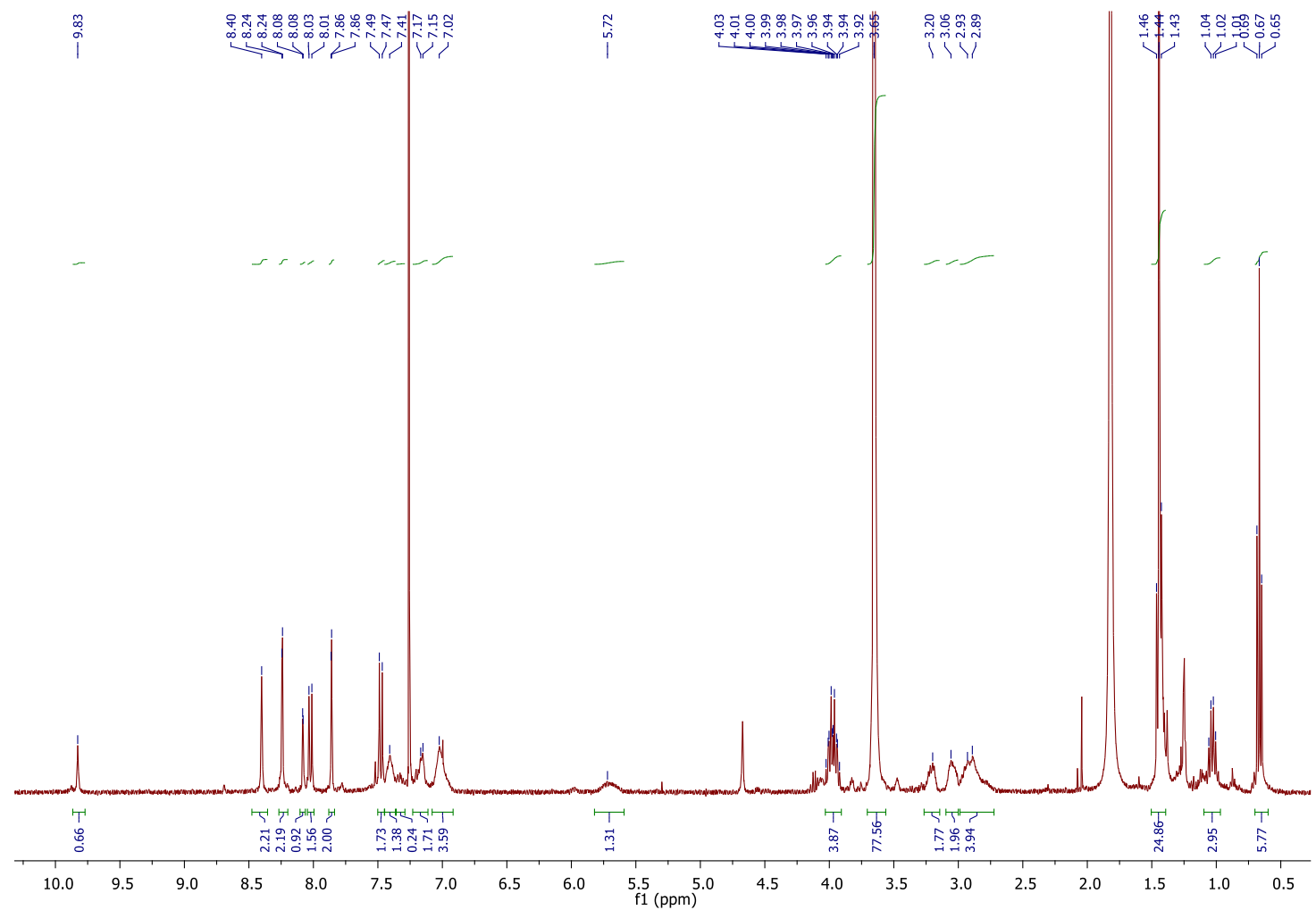

Figure S30. ${ }^{1} \mathrm{H}$ NMR spectrum of the $\mathrm{CDCl}_{3}$ phase containing the macrocycle $(S)-2$ and 18-crown-6 ether after extraction of L-phenylalanine. 


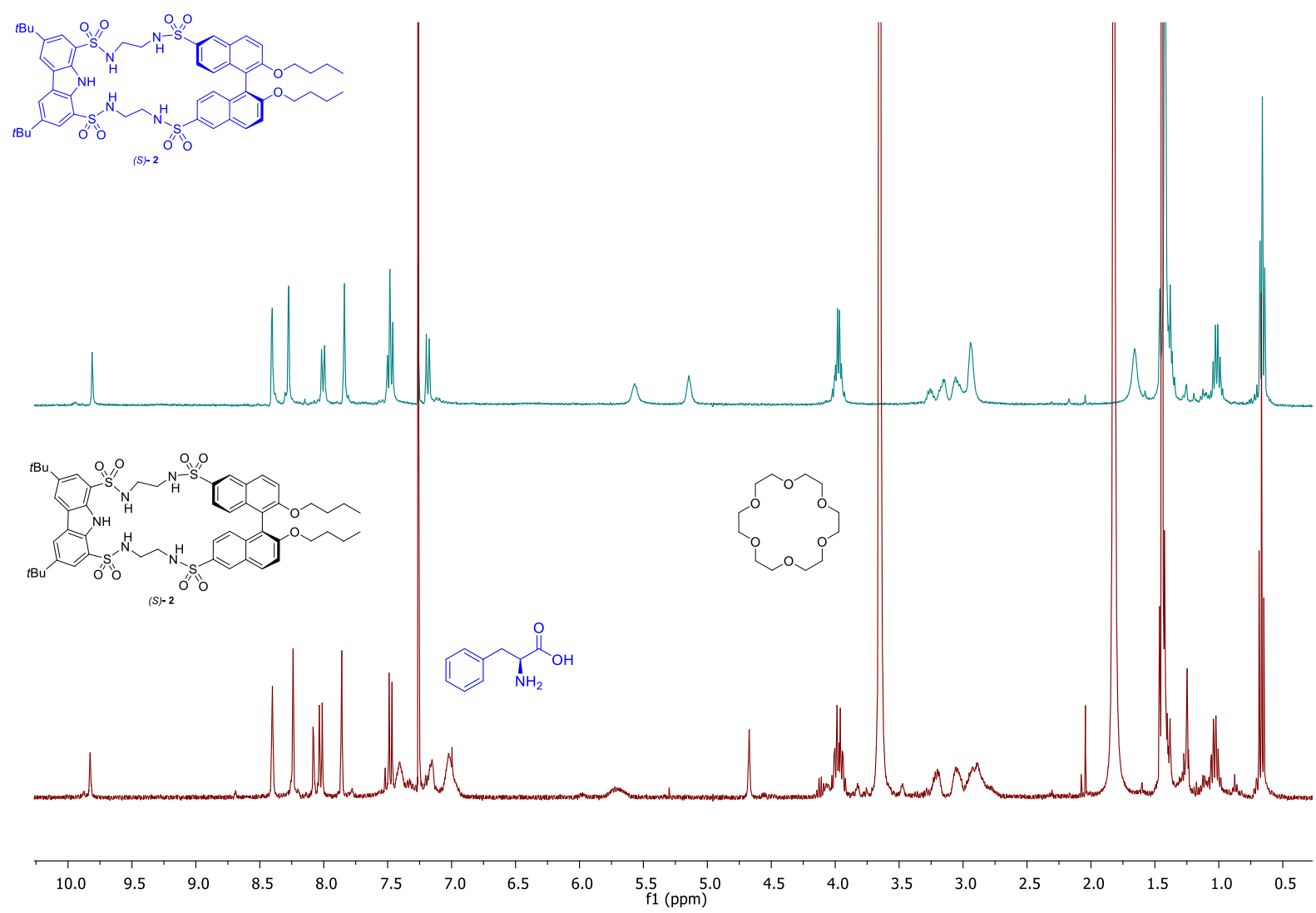

Figure S31. Comparison of the ${ }^{1} \mathrm{H}$ NMR spectra of macrocycle 2 (top) and the $\mathrm{CDCl}_{3}$ phase containing macrocycle (S)-2 and 18-crown-6-ether after extraction of L-phenylalanine (bottom). 


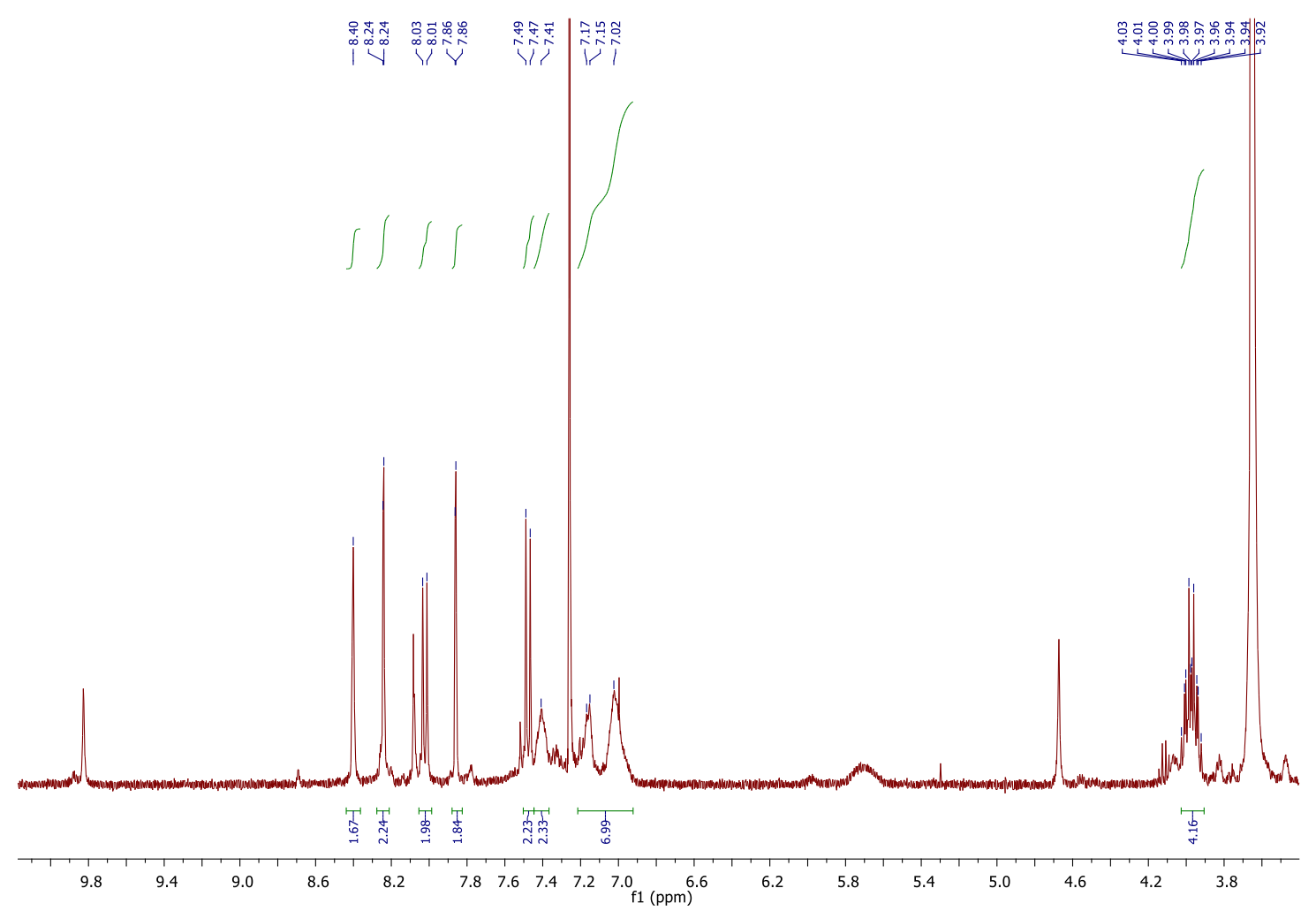

Figure S32. Integration of the ${ }^{1} \mathrm{H}$ NMR spectrum after extraction of L-phenylalanine (1:1 stoichiometry is proposed for the complex). 


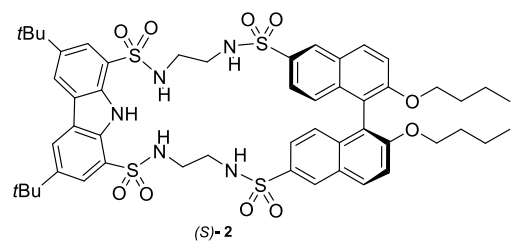

|

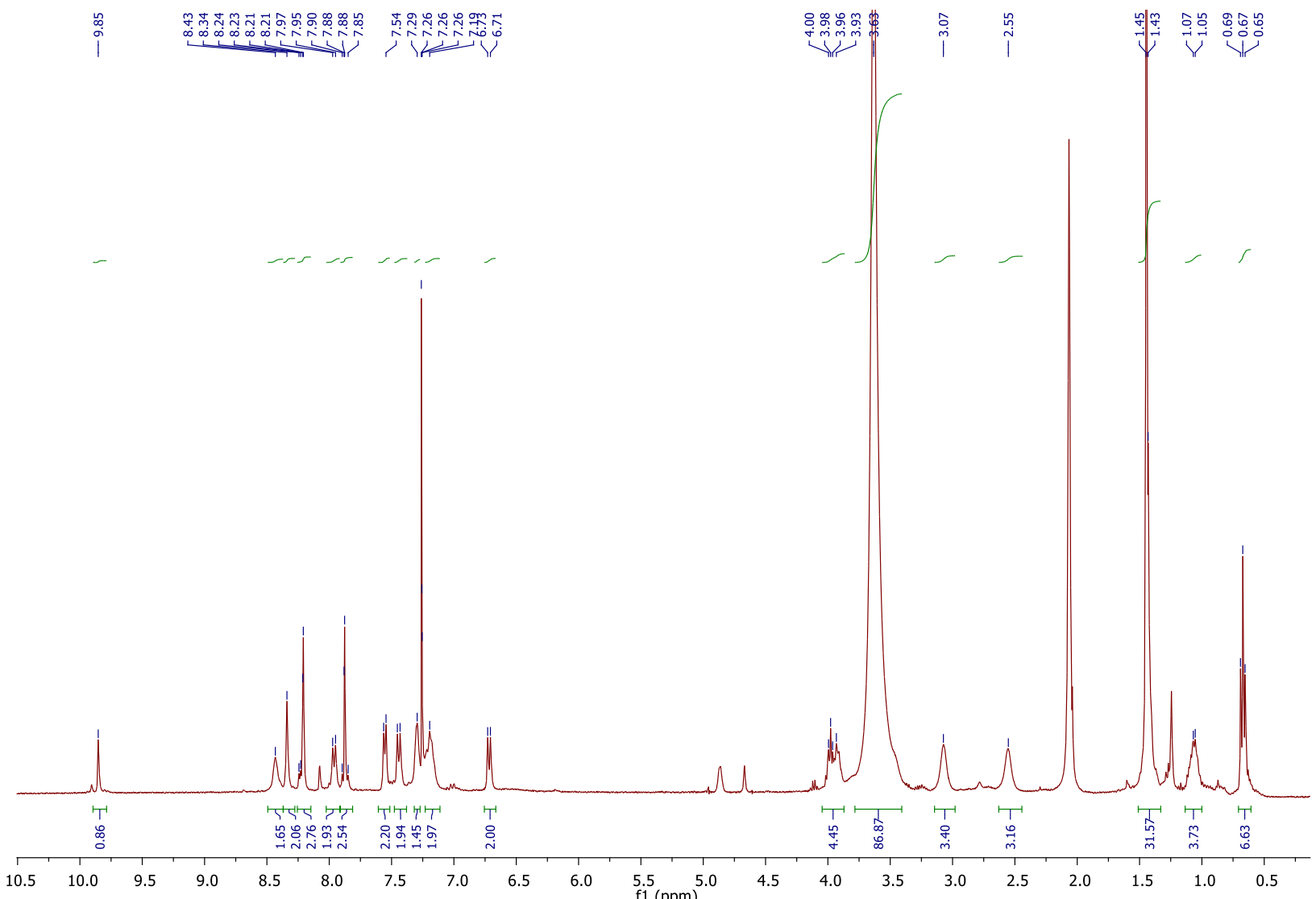

Figure S33. ${ }^{1} \mathrm{H}$ NMR spectrum of the $\mathrm{CDCl}_{3}$ phase containing macrocycle $(S)$-2 and 18-crown-6-ether after extraction of L-phenyglycine.

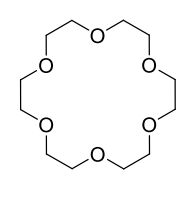

$\underbrace{\ominus}_{\oplus \mathrm{NH}_{3}}$ 


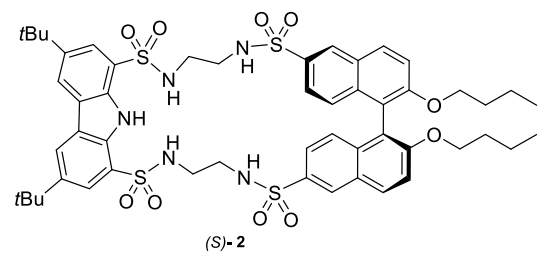<smiles>C1COCCOCCOCCOCCOCCO1</smiles><smiles>[NH3+][C@@H](C(=O)[O-])c1ccccc1</smiles>

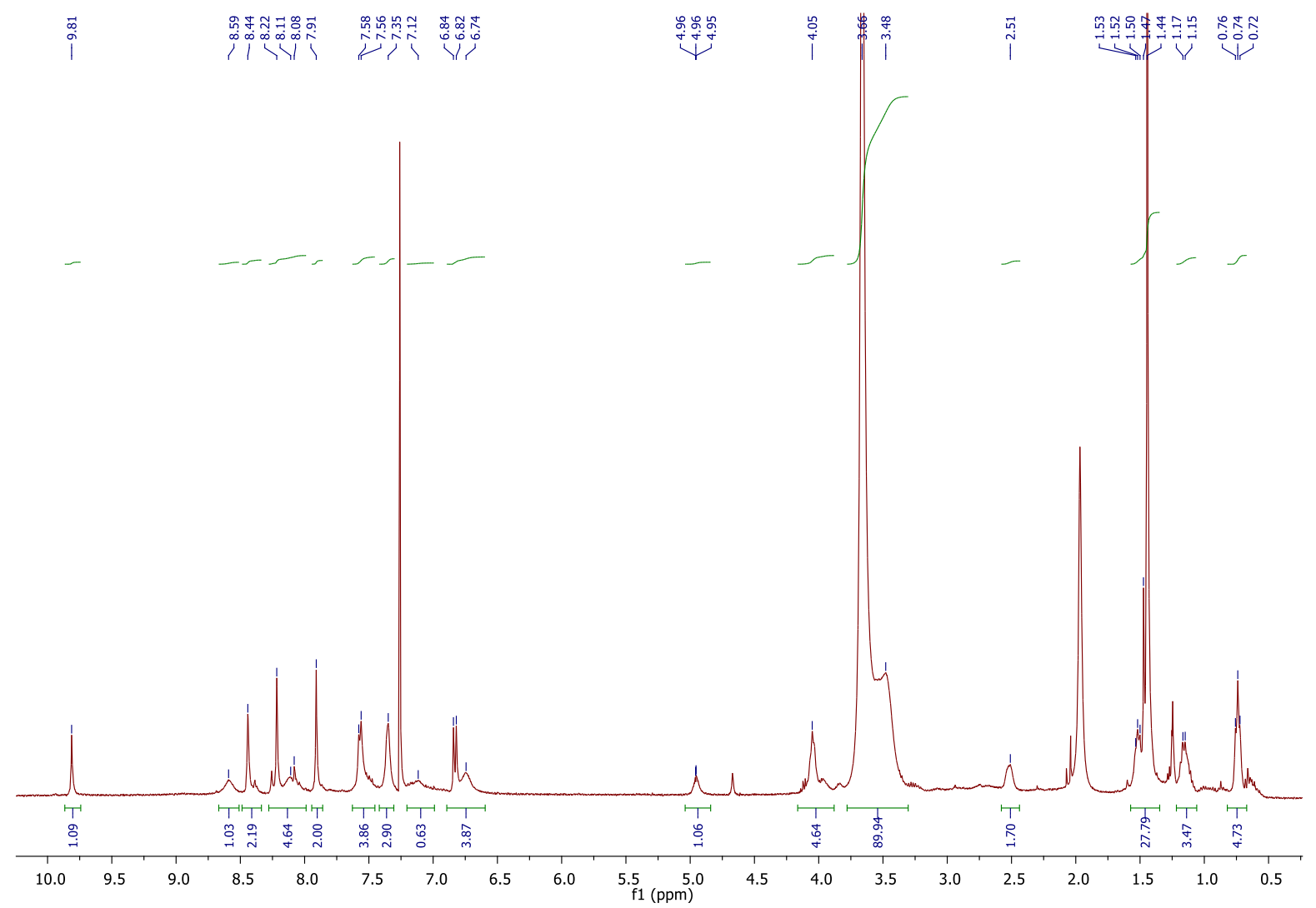

Figure S34. ${ }^{1} \mathrm{H}$ NMR spectrum of the $\mathrm{CDCl}_{3}$ phase containing macrocycle $(S)-2$ and 18 -crown-6 ether after extraction of D-phenyglycine. 

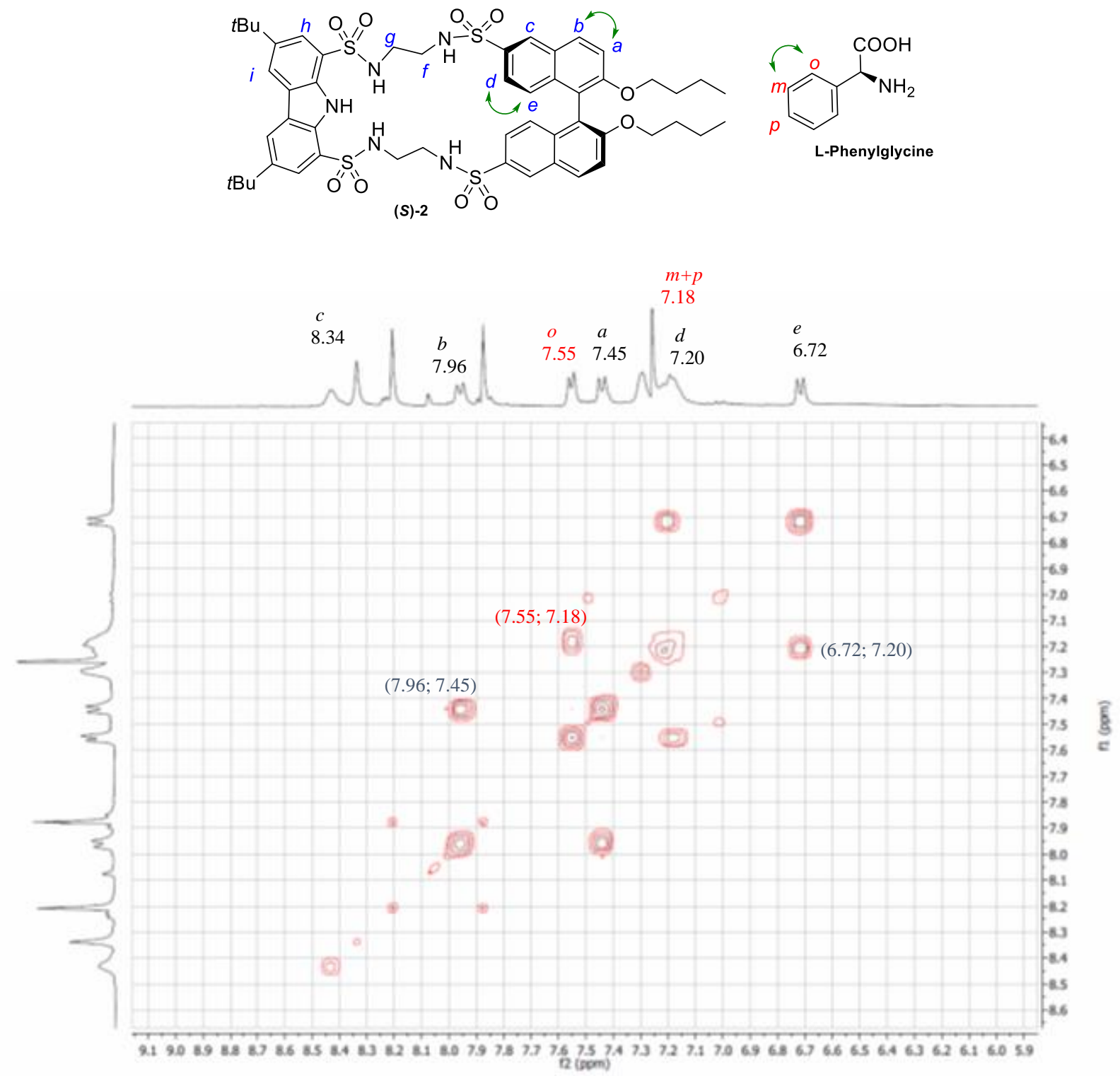

Figure S35. Aromatic region of COSY spectrum of the $\mathrm{CDCl}_{3}$ phase containing macrocycle $(S)-2$ and 18-crown-6 ether after extraction of L-phenyglycine. 

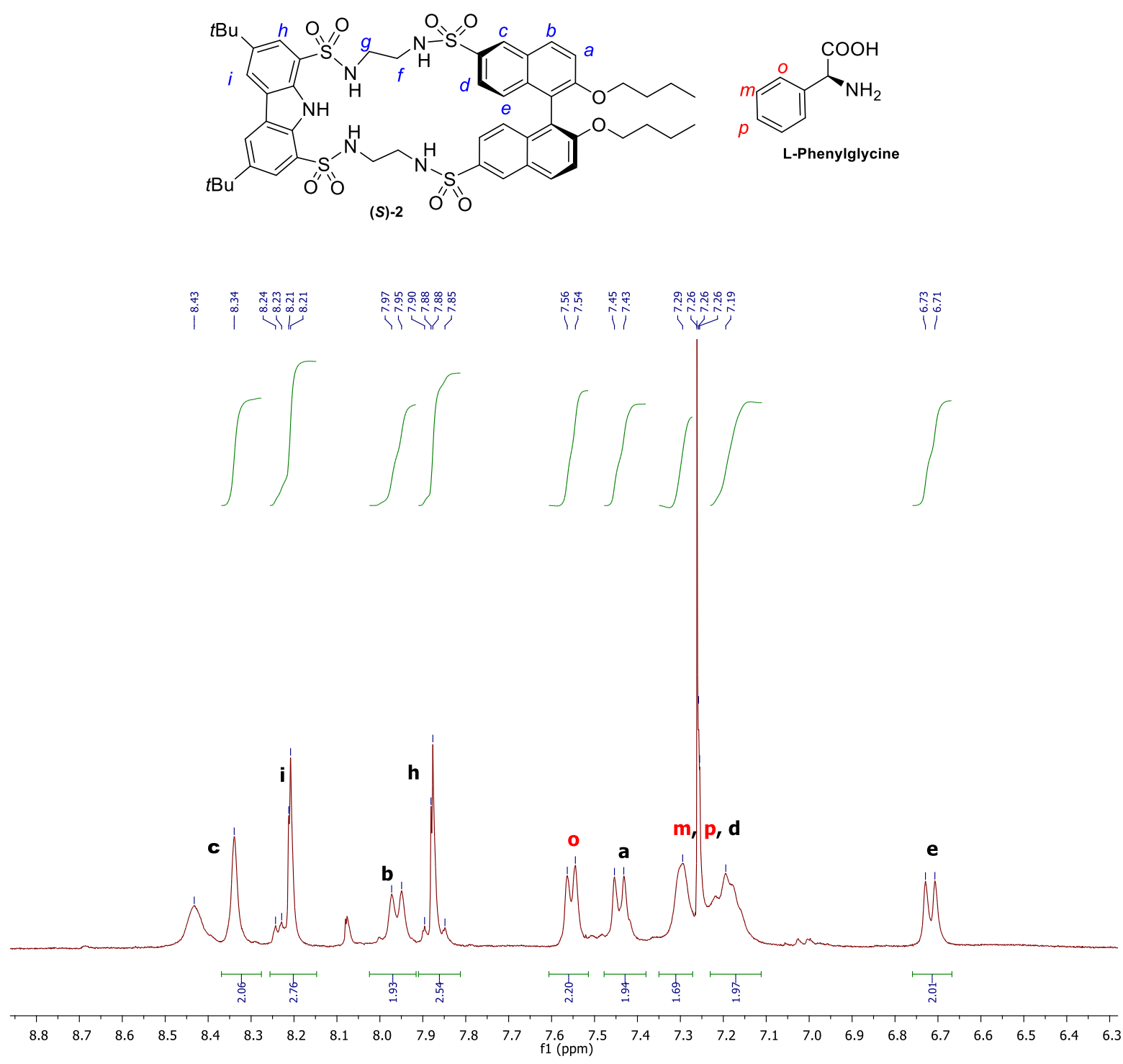

Figure S36. Integration of the ${ }^{1} \mathrm{H}$ NMR spectrum after extraction of L-Phenylglycine (1:1 stoichiometry is proposed for the complex). 

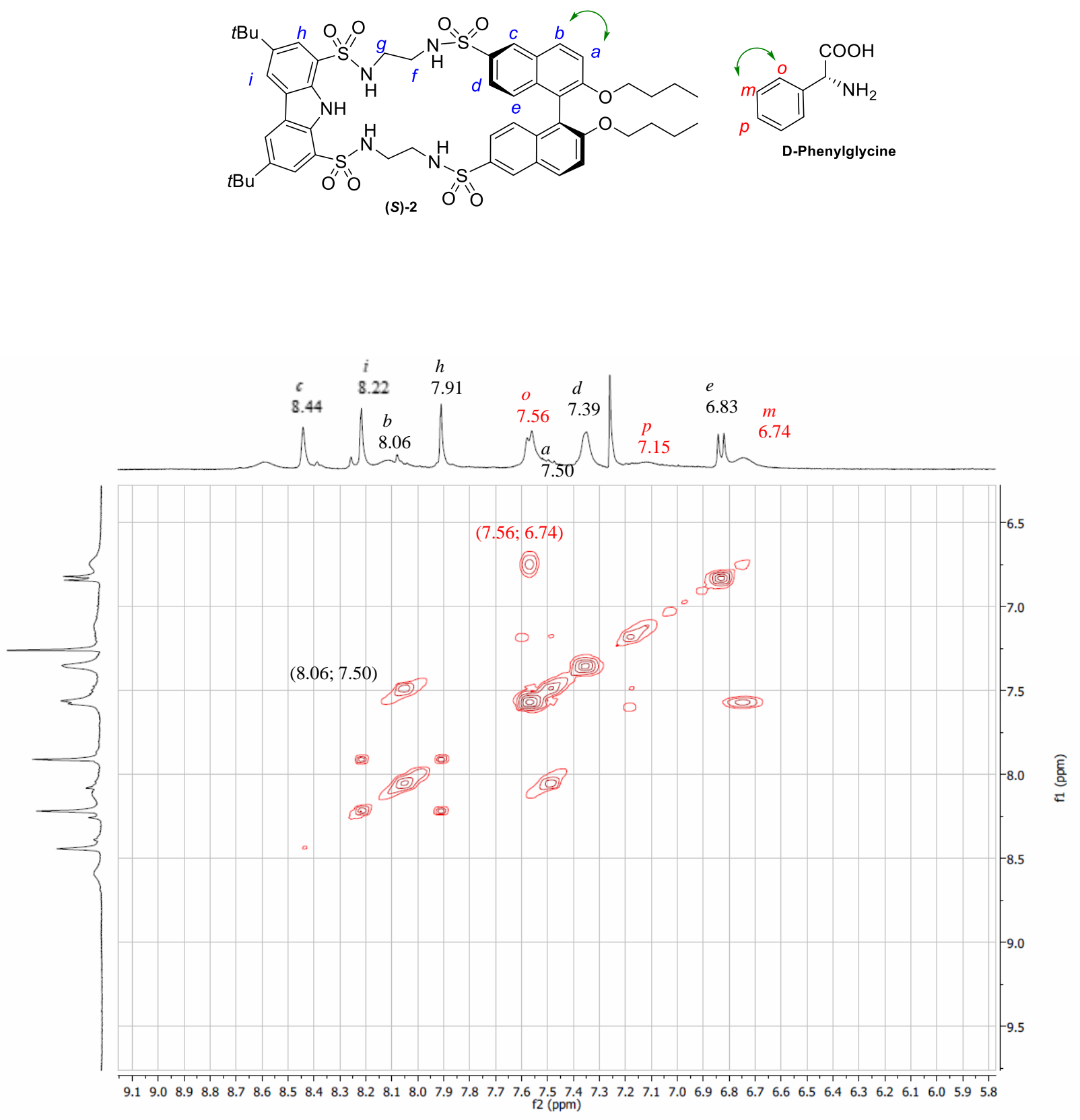

Figure S37. Aromatic region of COSY spectrum of the $\mathrm{CDCl}_{3}$ phase containing macrocycle $(S)$ - 2 and 18-crown-6 ether after extraction of D-phenyglycine. 

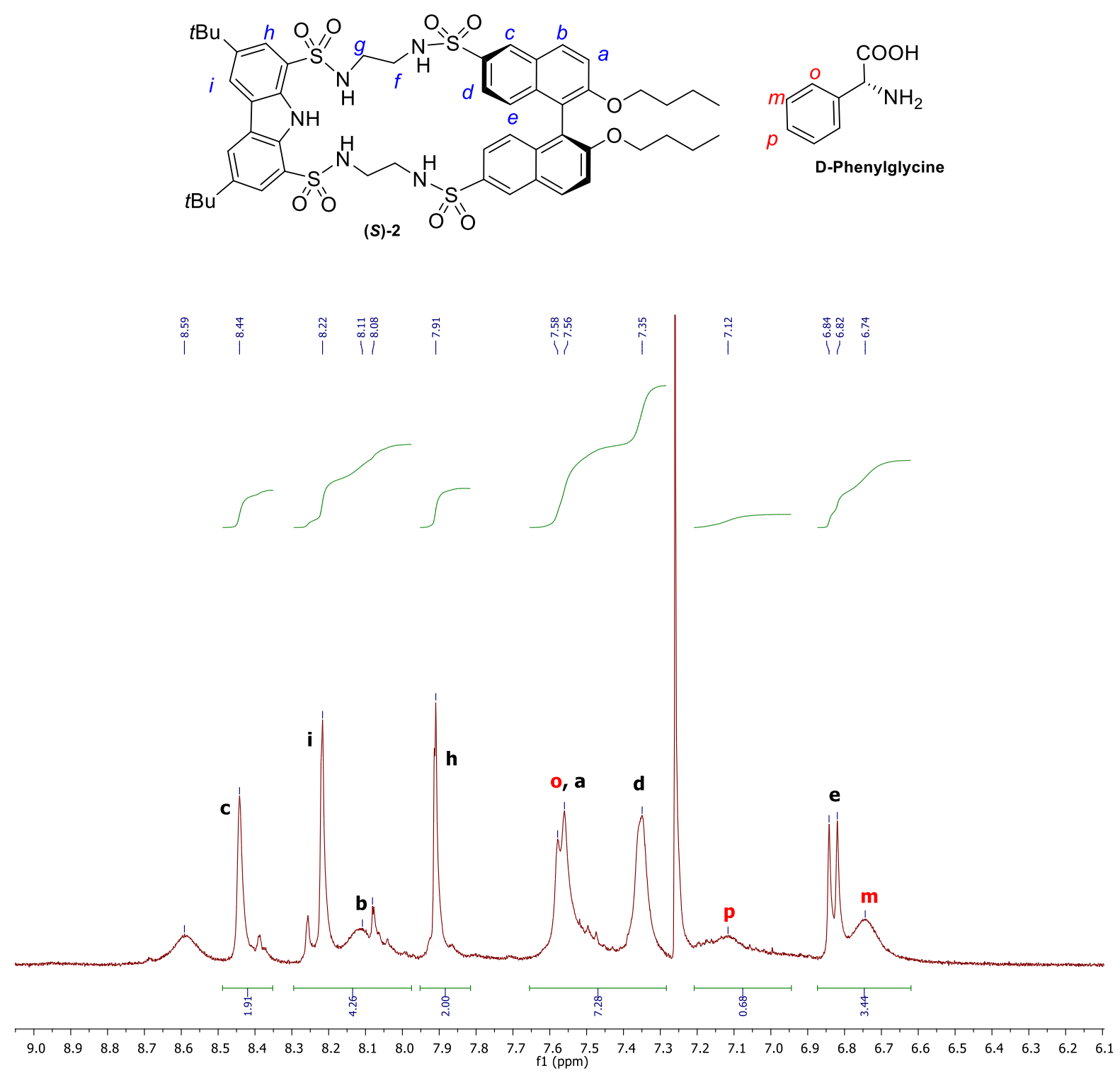

Figure S38. Integration of the ${ }^{1} \mathrm{H}$ NMR spectrum after extraction of D-Phenylglycine $(1: 1$ stoichiometry is proposed for the complex). 

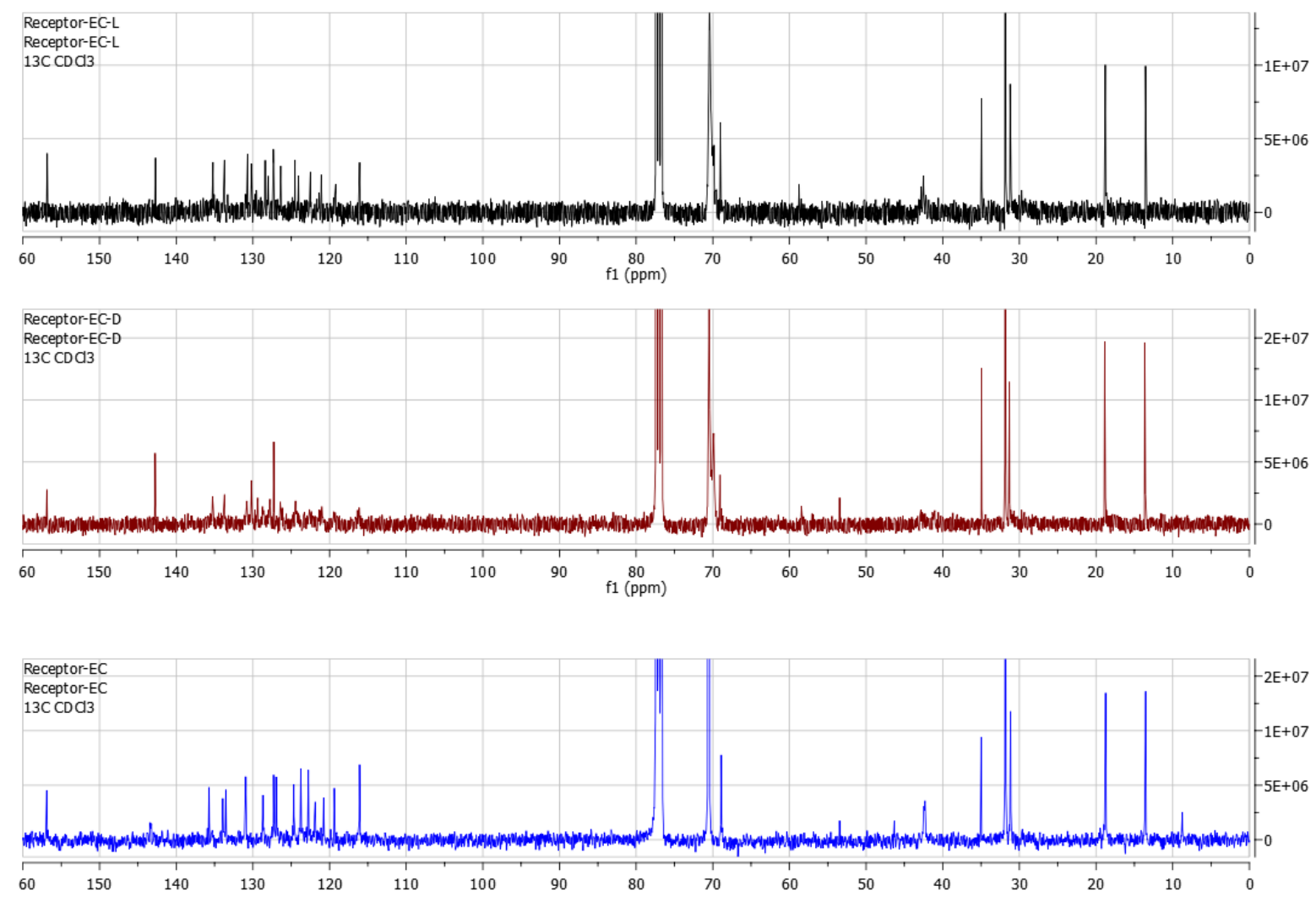

Figure S39. Comparison of ${ }^{13} \mathrm{C}$ NMR spectra corresponding to macrocycle (S)-2 and 18-crown-6 ether (bottom, in blue), after extraction of D-phenylglycine (middle, in red) and after extraction of Lphenylglycine (top, in black). 
Table S1. Chemical shifts of selected protons.

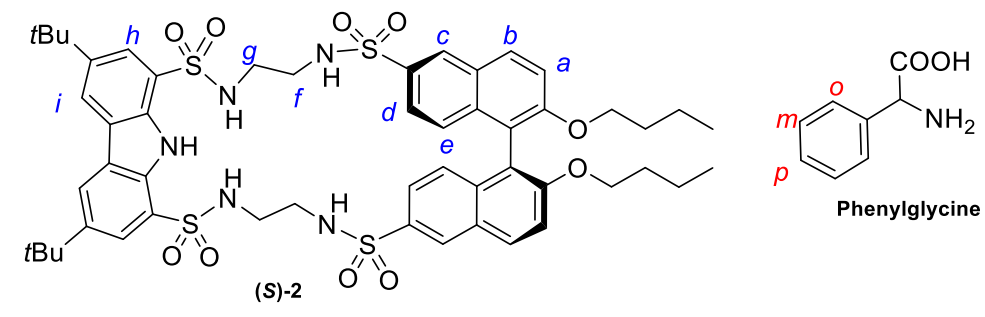

\begin{tabular}{|c|c|c|c|}
\hline \multirow[b]{2}{*}{ Proton } & \multicolumn{3}{|c|}{ Chemical shifts $\delta(\mathrm{ppm})^{a}$} \\
\hline & $(S)-\mathbf{2}$ & $(S)-2 \bullet$ D-phenylglycine & $(S)-2 \bullet L-p h e n y l g l y c i n e$ \\
\hline NH carbazole & 9.81 & 9.81 & 9.84 \\
\hline $\begin{array}{l}\mathrm{NH} \text { sulfonamide } \\
\text { carbazole }\end{array}$ & 5.57 & $8.59(\Delta \delta=3.02)$ & $8.43(\Delta \delta=2.86)$ \\
\hline $\begin{array}{l}\text { NH sulfonamide } \\
\text { binaphthyl }\end{array}$ & 5.14 & & \\
\hline $\mathrm{CH}_{2} g$ & 2.94 & $2.51(\Delta \delta=-0.43)$ & $2.56(\Delta \delta=-0.38)$ \\
\hline $\mathrm{H} d$ & 7.49 & $7.39(\Delta \delta=-0.10)$ & $7.20(\Delta \delta=-0.29)$ \\
\hline $\mathrm{He}$ & 7.19 & $6.83(\Delta \delta=-0.36)$ & $6.72(\Delta \delta=-0.47)$ \\
\hline Phenylglycine & & $6.74(m)$ & $7.18(m)$ \\
\hline Phenylglycine & & $7.56(o)$ & $7.55(o)$ \\
\hline
\end{tabular}

${ }^{a}$ Chemical shifts for multiplets correspond to the middle of the signal. Solvent $\mathrm{CDCl}_{3}$. 
a) $2\left(1.15 \times 10^{-2} \mathrm{M}\right)+2$ eq 18 -crown- 6 ether in $0.5 \mathrm{~mL}$ $\mathrm{CDCl}_{3}$

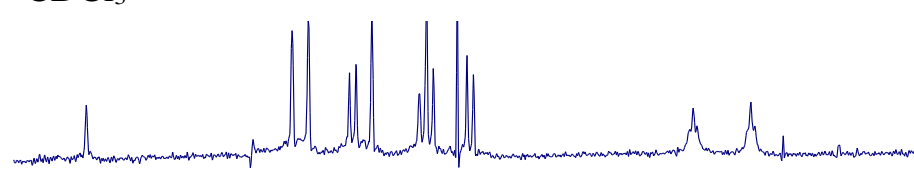

b) $2\left(1.15 \times 10^{-2} \mathrm{M}\right)+2$ eq 18 -crown- 6 ether in $0.5 \mathrm{~mL}$ $\mathrm{CDCl}_{3}+0.5 \mathrm{~mL}$ of a saturated solution of L-phenylglycine in $\mathrm{D}_{2} \mathrm{O}$

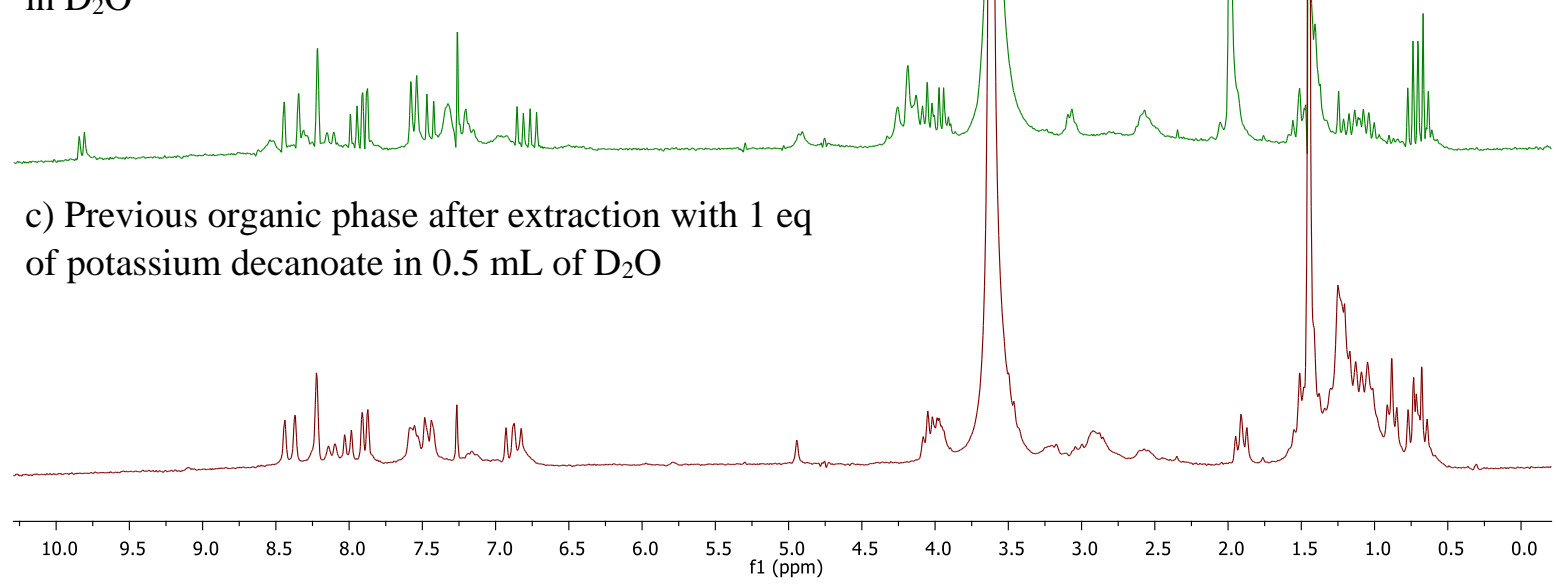

a) Aqueous phase after extraction with 1 eq of potassium decanoate

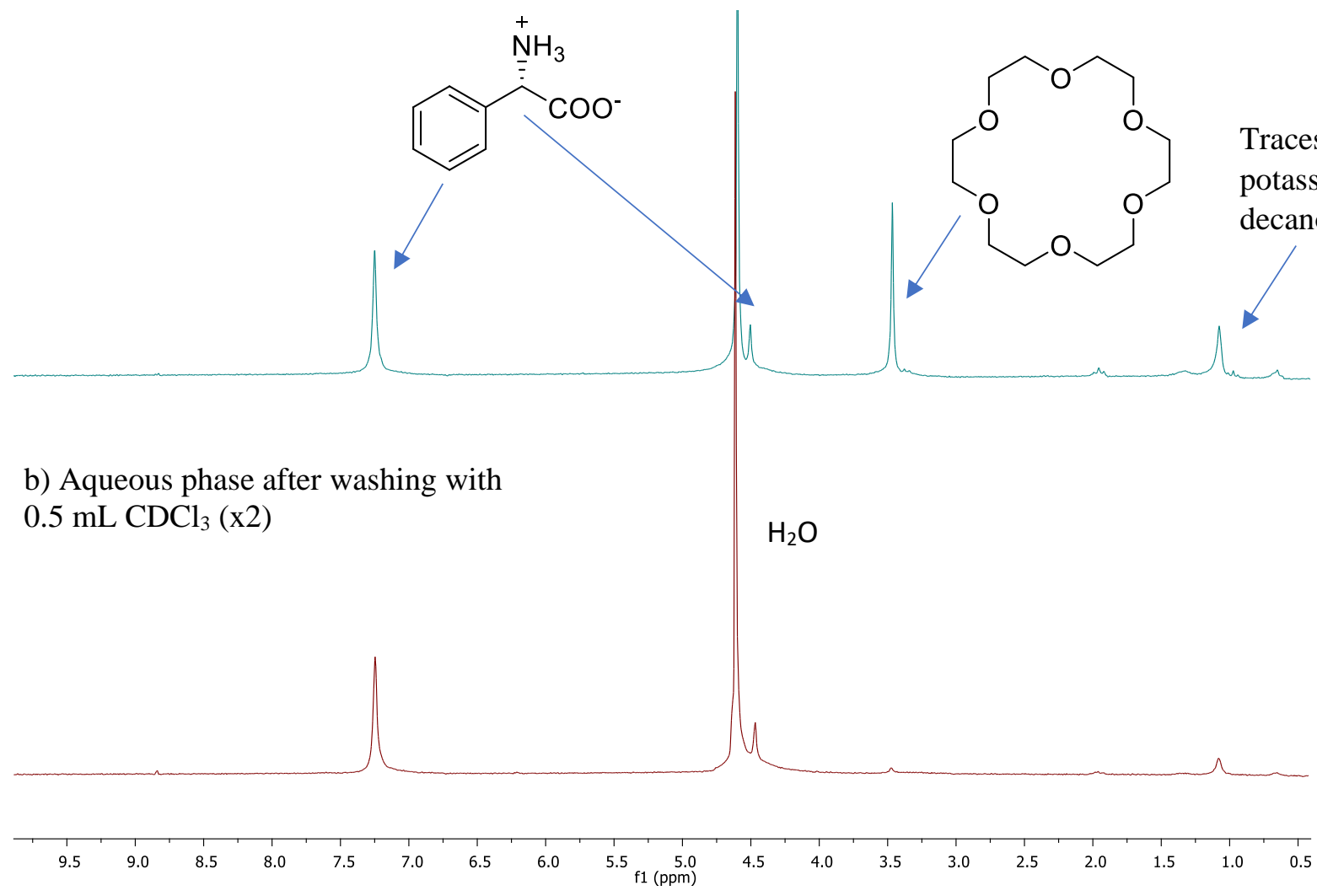

Figure S40. ${ }^{1} \mathrm{H}$ NMR spectra showing the isolation of L-phenylglycine after complexation with macrocycle 2. 


\section{RESOLUTION OF ENANTIOMERS OF THE MACROCYCLIC RECEPTOR 2 USING TLC IMPREGNATED WITH L-AMINO ACIDS.}

Conventional TLC plates were impregnated with a $1.5 \%$ aqueous solution of the L-amino acid (phenylglycine or phenylalanine) and the stoichiometric amount of the crown ether (18-crown-6 ether) and dried. The chiral stationary phase thus obtained was useful for the separation of the macrocycle enantiomers: elution with the solvent system methylene chloride/diethyl ether (4:1) afforded two separated spots, corresponding to the diastereomeric complexes of L-phenylglycine with each enantiomer of the racemic macrocycle 2.

On the other hand, for L-phenylalanine, both spots were not well separated.

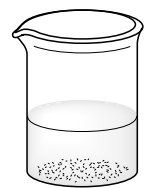

Preparation of $1.5 \%$ aqueous solution of the Lamino acid (L-

phenylglycine or $L$ phenylalanine) and the stoichiometric amount of the 18-crown-6 ether

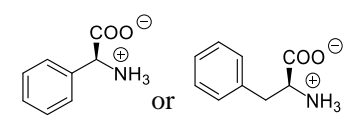

and

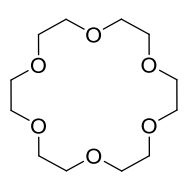

(S)-2 eluted in a TLC impregnated with Dphenylglycine

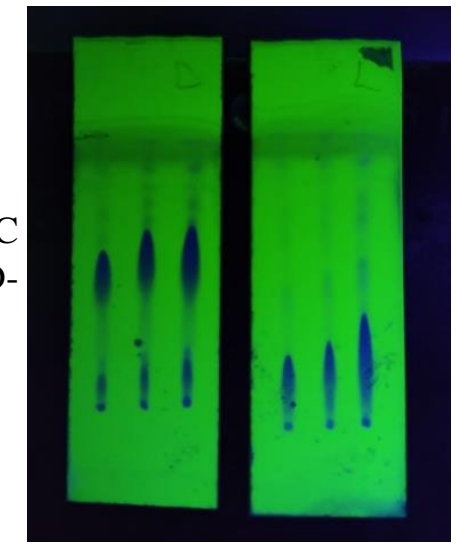

Impregnation of the TLC

Drying

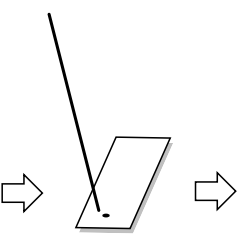

Racemic receptor 2 is applied
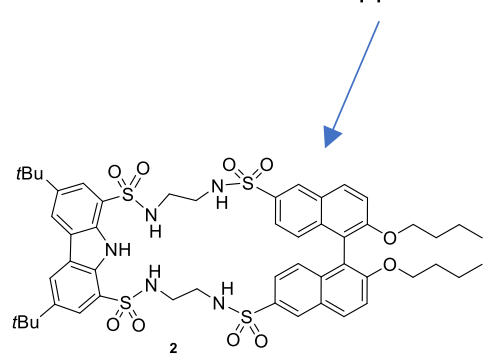

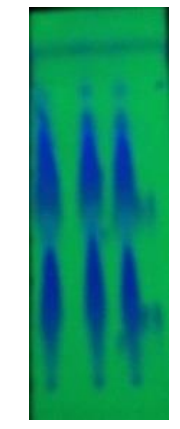

Two spots corresponding to the diastereomeric complexes with Lphenylglycine

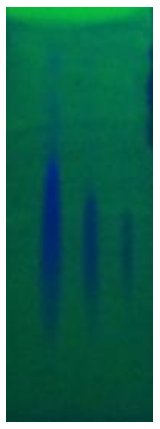

Both spots are not well separated when L-phenylalanine is used.
(S)-2 eluted in a TLC impregnated with Lphenylglycine

Figure S41. Scheme of the TLC resolution of racemic macrocycle 2. 


\section{CHIRAL HPLC CHROMATOGRAMS}

Servicio General de Espectrometria de Masas

Plaza de los Caídos 1-5. 37008 Salamanca

Emitido por César Raposo (Responsable SGEM)

Analysis Name: QUIN0208.D Instrument LC-MSD-Trap-XCT

Method: AMACMIX.M Operator: Administrator

Print Date: 10/30/2013 11:07:17 AM

Sample Na Phenylglycine (racemic)

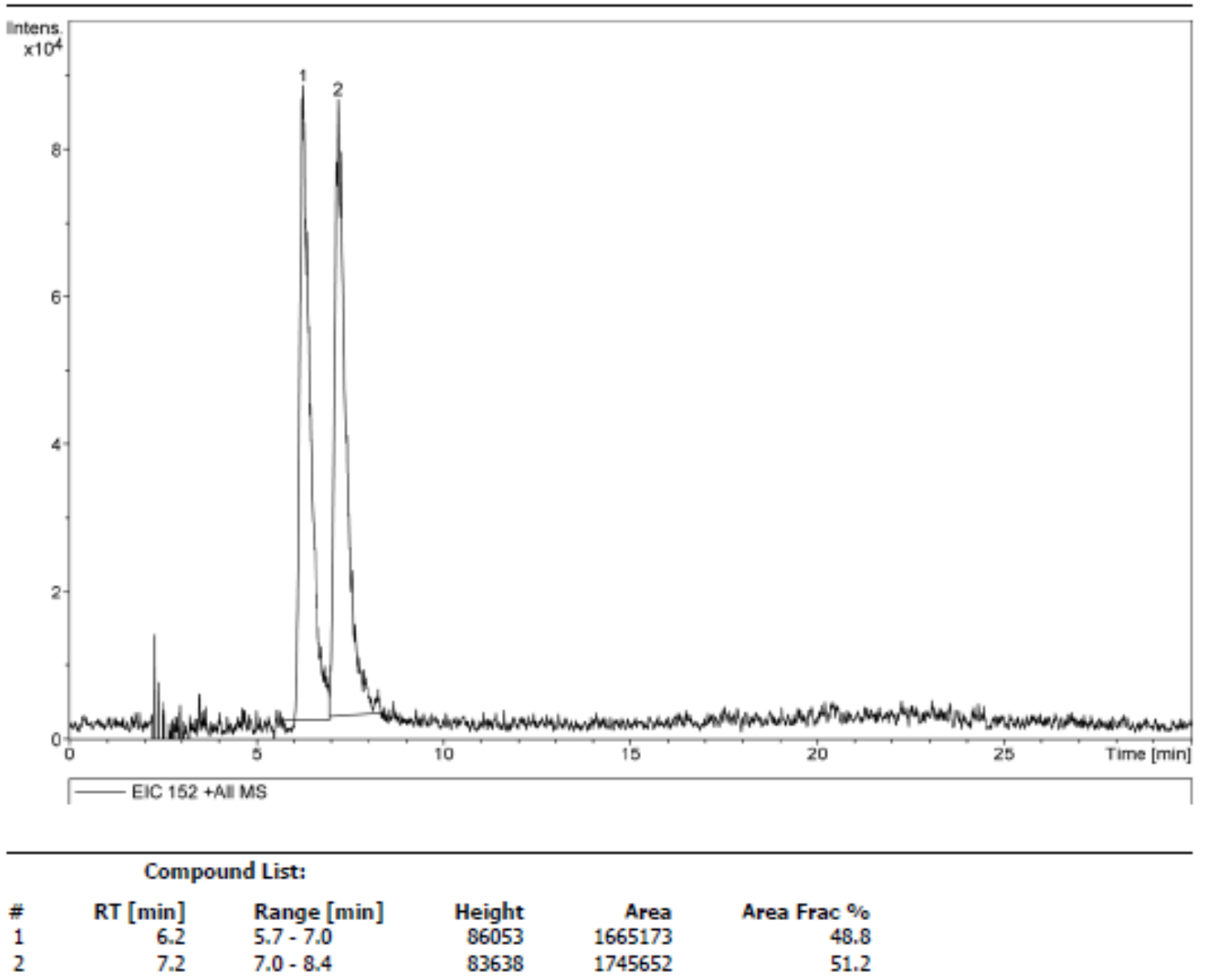

Figure S42. HPLC chromatogram of racemic phenylglycine. 
Analysis Name: QUINO206.D

Method: AMACMIX.M

Instrument LC-MSD-Trap-XCT

Sample Na

Phenylalanine (racemic)
Print Date: 10/30/2013 10:47:36 AM

Acq. Date: 10/30/2013 09:33:20 AM

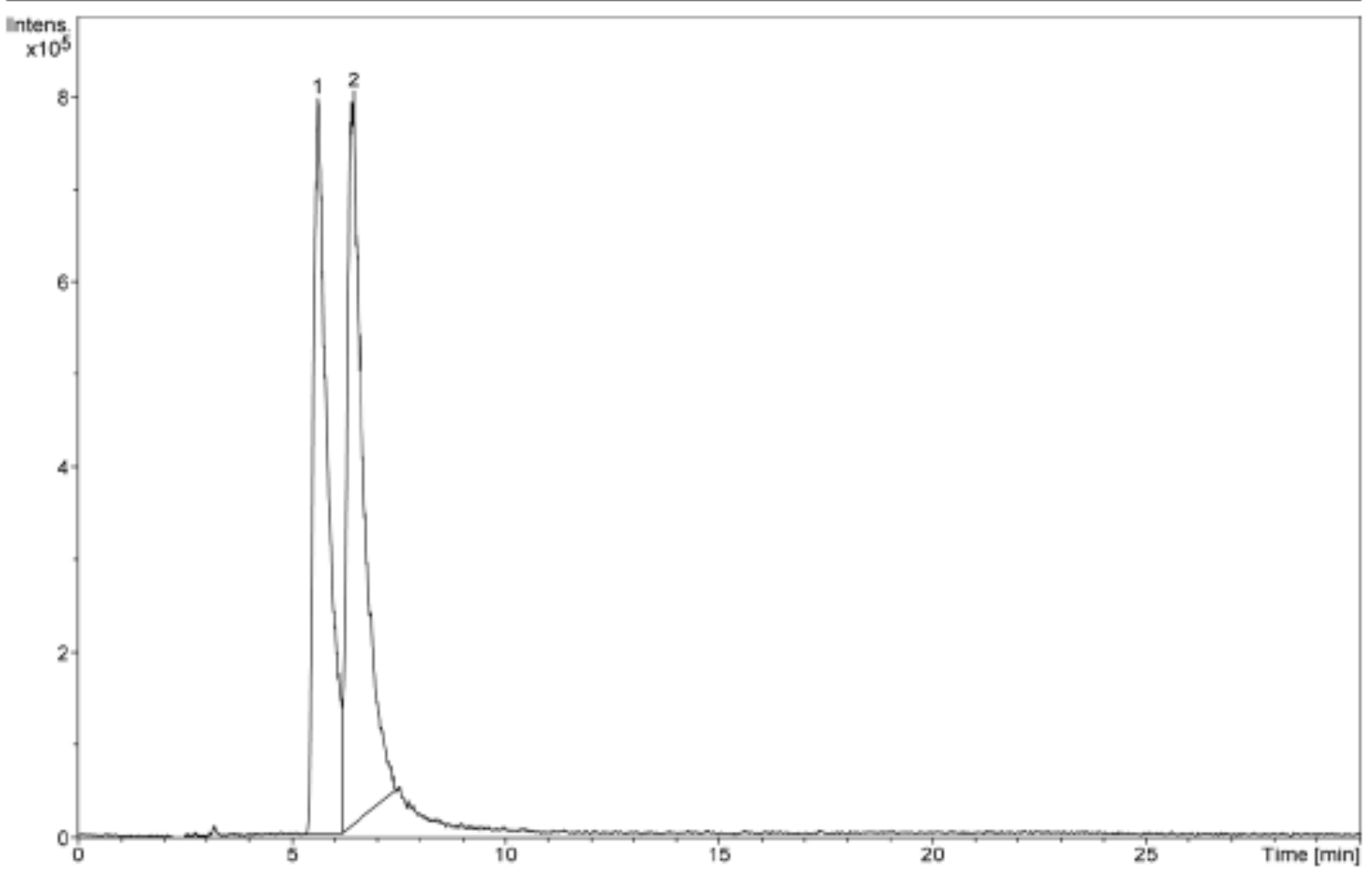

- EIC $166+$ All MS

\section{Compound List:}

$\begin{array}{rrlrrr}\# & \text { RT [min] } & \text { Range [min] } & \text { Height } & \text { Area } & \text { Area Frac \% } \\ 1 & 5.6 & 5.3-6.2 & 793265 & 18255007 & 46.0 \\ 2 & 6.4 & 6.2-7.4 & 791429 & 21461376 & 54.0\end{array}$

Figure S43. HPLC chromatogram of racemic phenylalanine. 
Servicio General de Espectrometria de Masas

Plaza de los Caídos 1-5. 37008 Salamanca

$\begin{array}{llll}\text { Analysis Name: QUINO209.D } & \text { Instrument } & \text { LC-MSD-Trap-XCT } \\ \text { Method: } & \text { AMACMIX.M } & \text { Operator: } & \text { Administrator } \\ \text { Sample Na } & \text { Phenylglycine (ext.) } & & \end{array}$
1 of 1

Emitido por César Raposo (Responsable SGEM)

Print Date: 10/30/2013 11:58:15 AM

Acq. Date: 10/30/2013 11:07:40 AM

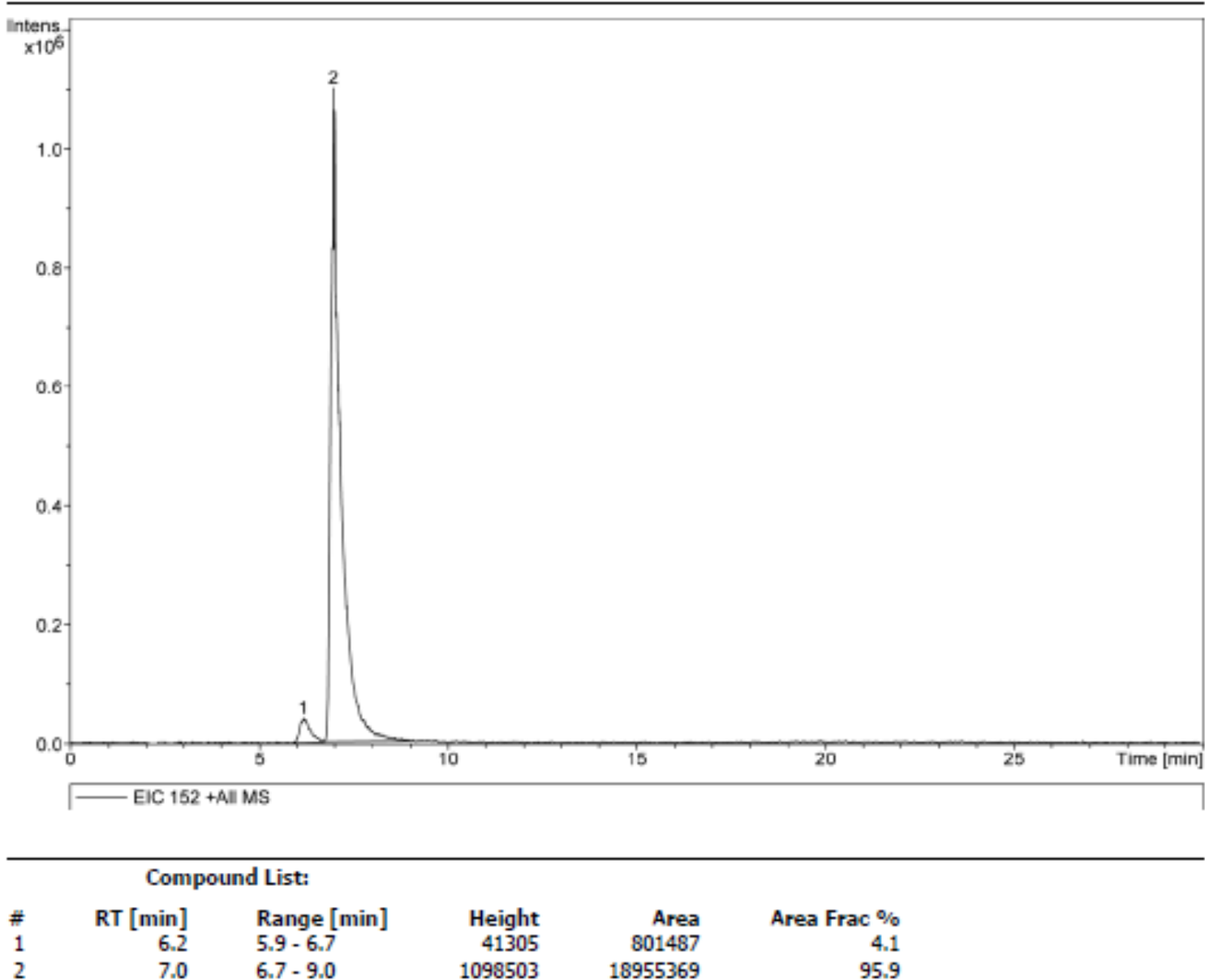

Figure S44. HPLC chromatogram of the organic phase after liquid-liquid extraction of aqueous racemic phenylglycine in the presence of macrocycle $(S)-2$ and 18-crown-6 ether. 
Analysis Name: QUINO207.D Instrument LC-MSD-Trap-XCT

Method: AMACMDX.M

Sample $\mathrm{Na}$

Phenylalanine (ext.)
Print Date: 10/30/2013 10:49:08 AM

Acq. Date: 10/30/2013 10:04:45 AM

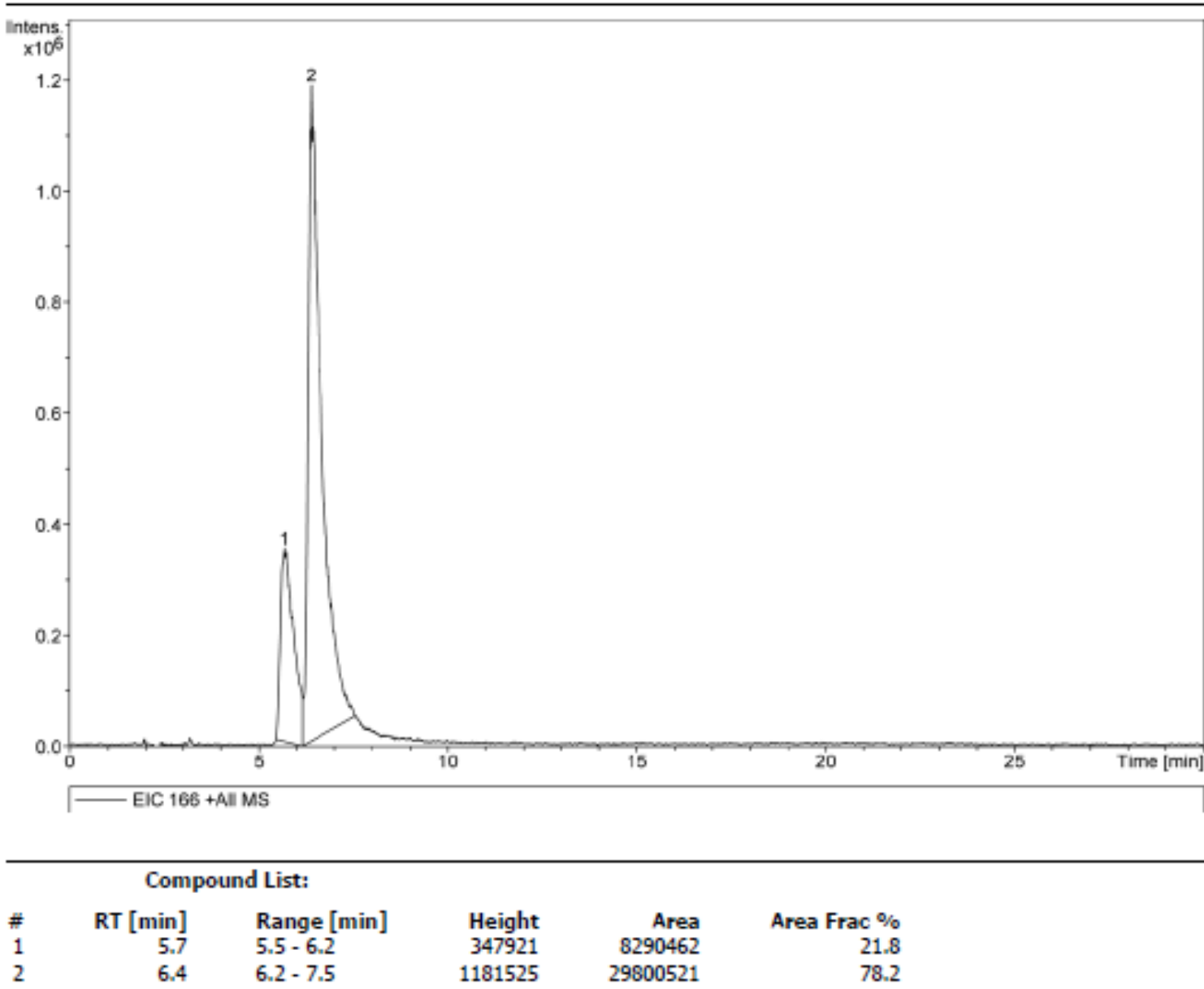

Figure S45. HPLC chromatogram of the organic phase after liquid-liquid extraction of aqueous racemic phenylalanine in the presence of macrocycle $(S)-2$ and 18 -crown-6 ether. 


\section{ORTEP DIAGRAMS AND X-RAY CRYSTAL STRUCTURE DATA}

A suitable single crystal of the ternary complex (macrocycle 2/ phenyl glycine/ 18-crown-ether-6) was mounted on glass fiber for data collection on a Bruker Kappa Apex II CCD diffractometer. Data were collected at $298 \mathrm{~K}$ using $\mathrm{Cu} \mathrm{K}_{\alpha}$ radiation $(\lambda=1.54178 \AA)$ and $\omega$ scan technique, and were corrected for Lorentz and polarization effects. The crystal structure was solved by direct methods combined with difference Fourier synthesis and refined by full-matrix least-squares fitting on $\mathrm{F}^{2}$ by the SHELXTL-97 program.[1] All the non-hydrogen atoms, except some disordered atoms and some isolated water solvent molecules, were refined anisotropically. The carbon atom sites (labeled C46, C47, C48 and C52) of the butyl groups are split on two positions each with an occupancy factor of 50\%. The hydrogen atoms were positioned geometrically. Due to diffuse electron density associated with solvent molecules of crystallization, the hydrogen atoms on solvent molecules cannot be generated but they are included in the molecular formula directly. The high $R_{1}$ and $w R_{2}$ factor both in the complex might be due to the disorder of the solvent and the weak crystal diffraction. CCDC-1441451 contains the supplementary crystallographic data for this paper. These data are provided free of charge by The Cambridge Crystallographic Data Centre.
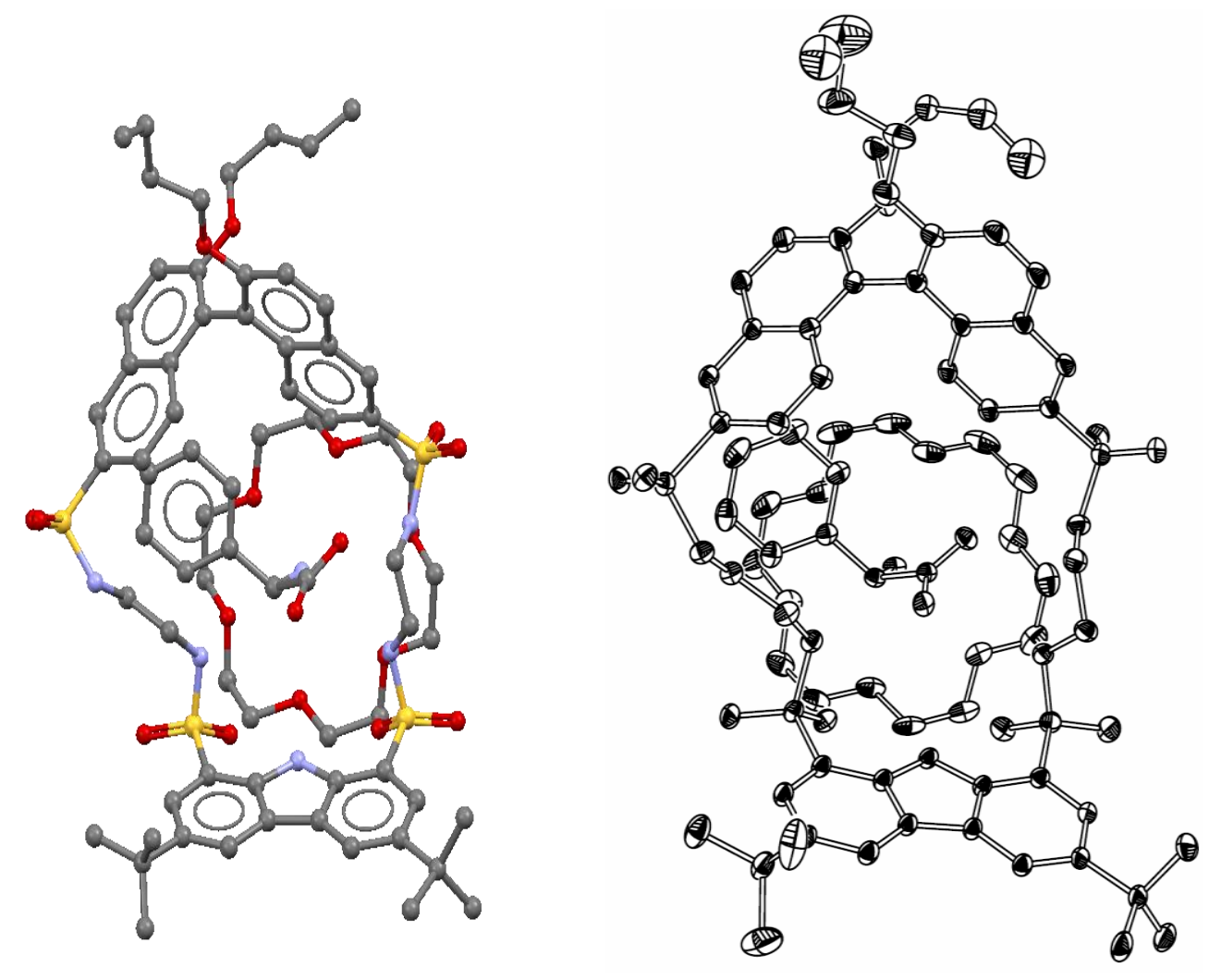

Figure S46. Molecular structure and ORTEP diagram of the 1:1:1 ternary complex formed by macrocycle 2, 18-crown-6-ether and phenylglycine. The hydrogen atoms and isolated solvent molecules are omitted for clarity. 
Table S2 Crystal data and structure refinement for the ternary complex.

Empirical formula

Formula weight

Temperature

Wavelength

Crystal system, space group

Unit cell dimensions

Volume

Z, Calculated density

Absorption coefficient

$\mathrm{F}(000)$

Crystal size

Theta range for data collection

Limiting indices

Reflections collected / unique

Refinement method

Data / restraints / parameters

Goodness-of-fit on F2

Final $\mathrm{R}$ indices [I $>2 \operatorname{sigma}(\mathrm{I})]$

$\mathrm{R}$ indices (all data)

Largest diff. peak and hole
C74 H107 N6 O23 S4

1578.78

298(2) K

$1.54178 \AA$

triclinic, $\mathrm{P} 1$

$\mathrm{a}=12.9759(3) \AA \mathrm{A}$ alpha $=109.208(2) \mathrm{deg}$.

$\mathrm{b}=18.8931(4) \AA$ beta $=98.025(2) \mathrm{deg}$.

$\mathrm{c}=19.4019(5) \AA$ gamma $=99.068(2) \mathrm{deg}$.

4341.05(18) 3

2, $1.196 \mathrm{Mg} / \mathrm{m} 3$

$1.595 \mathrm{~mm}-1$

1654

$0.10 \times 0.06 \times 0.04 \mathrm{~mm}$

2.46 to $67.33 \mathrm{deg}$.

$-15<=\mathrm{h}<=15,-22<=\mathrm{k}<=21,-22<=\mathrm{l}<=22$

$14467 / 14467[\mathrm{R}(\mathrm{int})=0.0570]$

Full-matrix least-squares on F2

1912 / 3 / 960

1.051

$\mathrm{R} 1=0.0838, \mathrm{wR} 2=0.2478$

$\mathrm{R} 1=0.1136, \mathrm{wR} 2=0.2830$

1.033 and -0.397 e. $\AA-3$ 
Table S3. Hydrogen-bond geometry $\left(\AA{ }^{\circ}{ }^{\circ}\right)$

\begin{tabular}{|c|c|c|c|c|}
\hline $\mathrm{D}-\mathbf{H} \cdots \mathbf{A}$ & $\mathbf{D}-\mathbf{H}$ & $H \cdots A$ & $\mathbf{D} \cdots \mathbf{A}$ & $\mathrm{D}-\mathrm{H} \cdots \mathrm{A}$ \\
\hline $\mathrm{N} 2-\mathrm{H} 2 \mathrm{~N} \cdots \mathrm{O} 12$ & 0.86 & 2.08 & $2.834(1)$ & 146 \\
\hline $\mathrm{N} 4-\mathrm{H} 4 \mathrm{~N} \cdots \mathrm{O} 11$ & 0.86 & 2.15 & $2.988(3)$ & 119 \\
\hline $\mathrm{N} 5-\mathrm{H} 5 \mathrm{~N} \cdots \mathrm{O} 12$ & 0.86 & 2.47 & $2.914(3)$ & 147 \\
\hline 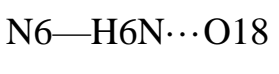 & 0.89 & 2.17 & $2.994(2)$ & 153 \\
\hline N6-H6C $\cdots \mathrm{O} 13$ & 0.89 & 2.46 & $3.128(1)$ & 132 \\
\hline N6-H6A $\cdots$ O14 & 0.89 & 2.17 & $2.984(2)$ & 151 \\
\hline $\mathrm{N} 6-\mathrm{H} 6 \mathrm{~B} \cdots \mathrm{O} 16$ & 0.89 & 2.02 & $2.902(1)$ & 173 \\
\hline N6-H6B $\cdots \mathrm{O} 17$ & 0.89 & 2.57 & $3.029(2)$ & 112 \\
\hline
\end{tabular}
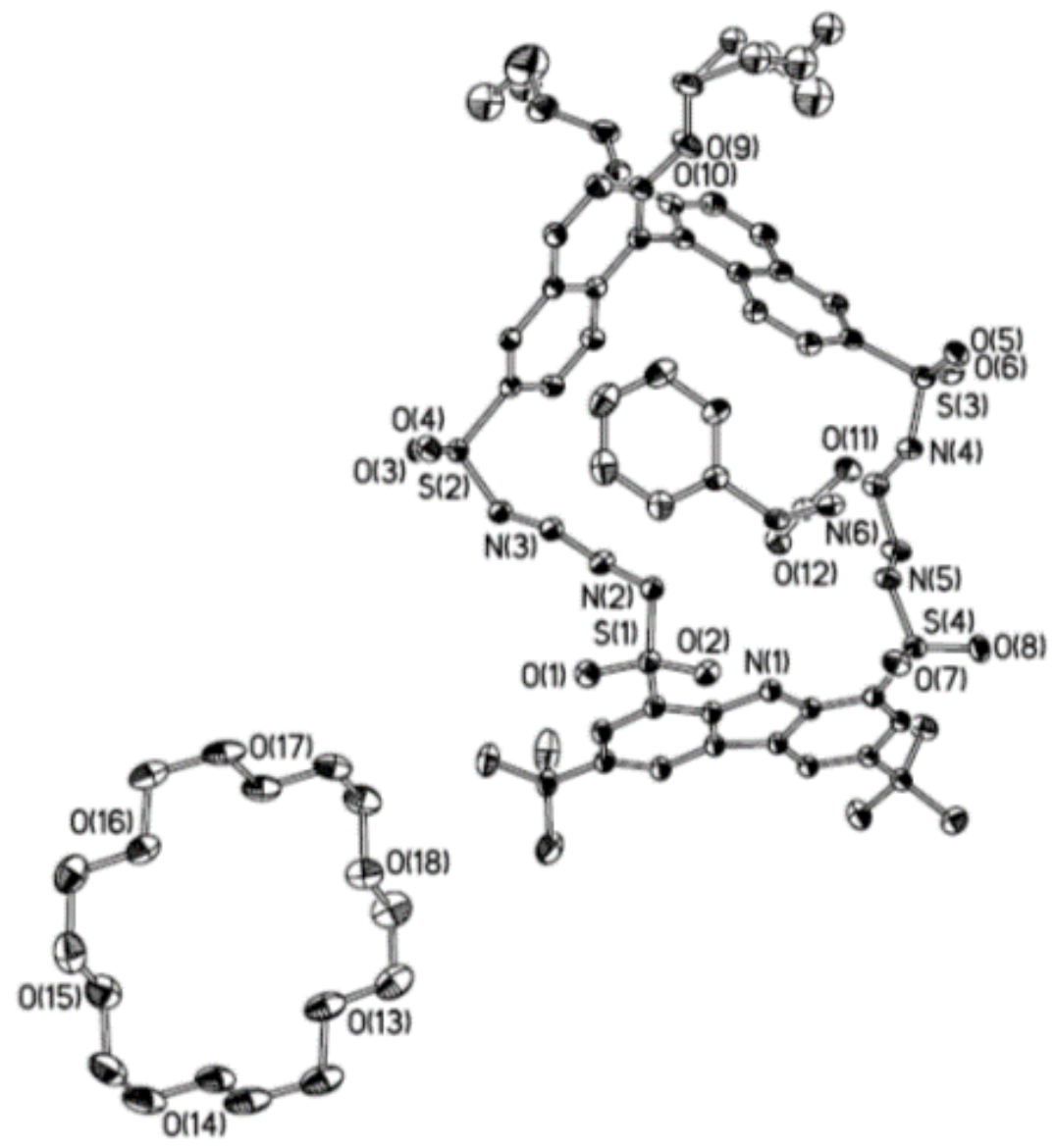
Table S4. Distances $(\AA)$ from the X-ray structures of receptor 2 with phenylglycine and 18-crown-6 ether.

$\begin{array}{llll}\text { Entry } & \mathrm{D}-\mathrm{H} \cdots \mathrm{A} & \mathrm{H} \cdots \mathrm{A} & \mathrm{D} \cdots \mathrm{A} \\ 1^{a} & \mathrm{NH}_{\text {sulfonamide }} \cdots \mathrm{O}_{\text {carboxylate }} & 2.08 & 2.834 \\ 2^{a} & \mathrm{NH}_{\text {sulfonamide }} \cdots \mathrm{O}_{\text {carboxylate }} & 2.47 & 2.914 \\ 3^{a} & \mathrm{NH}_{\text {sulfonamide }} \cdots \mathrm{O}_{\text {carboxylate }} & 2.15 & 2.988 \\ 4^{b} & \mathrm{NH}_{\text {ammonium }} \cdots \mathrm{O}_{\text {crown ether }} & 2.17 & 2.994 \\ 5^{b} & \mathrm{NH}_{\text {ammonium }} \cdots \mathrm{O}_{\text {crown ether }} & 2.46 & 3.128 \\ 6^{b} & \mathrm{NH}_{\text {ammonium }} \cdots \mathrm{O}_{\text {crown ether }} & 2.17 & 2.984 \\ 7^{b} & \mathrm{NH}_{\text {ammonium }} \cdots \mathrm{O}_{\text {crown ether }} & 2.02 & 2.902 \\ 8^{b} & \mathrm{NH}_{\text {ammonium }} \cdots \mathrm{O}_{\text {crown ether }} & 2.57 & 3.029\end{array}$

${ }^{a}$ Hydrogen bonds with the carboxylate of the amino acid. ${ }^{b} \mathrm{Hydrogen}$ bonds established by the ammonium group of the amino acid. 

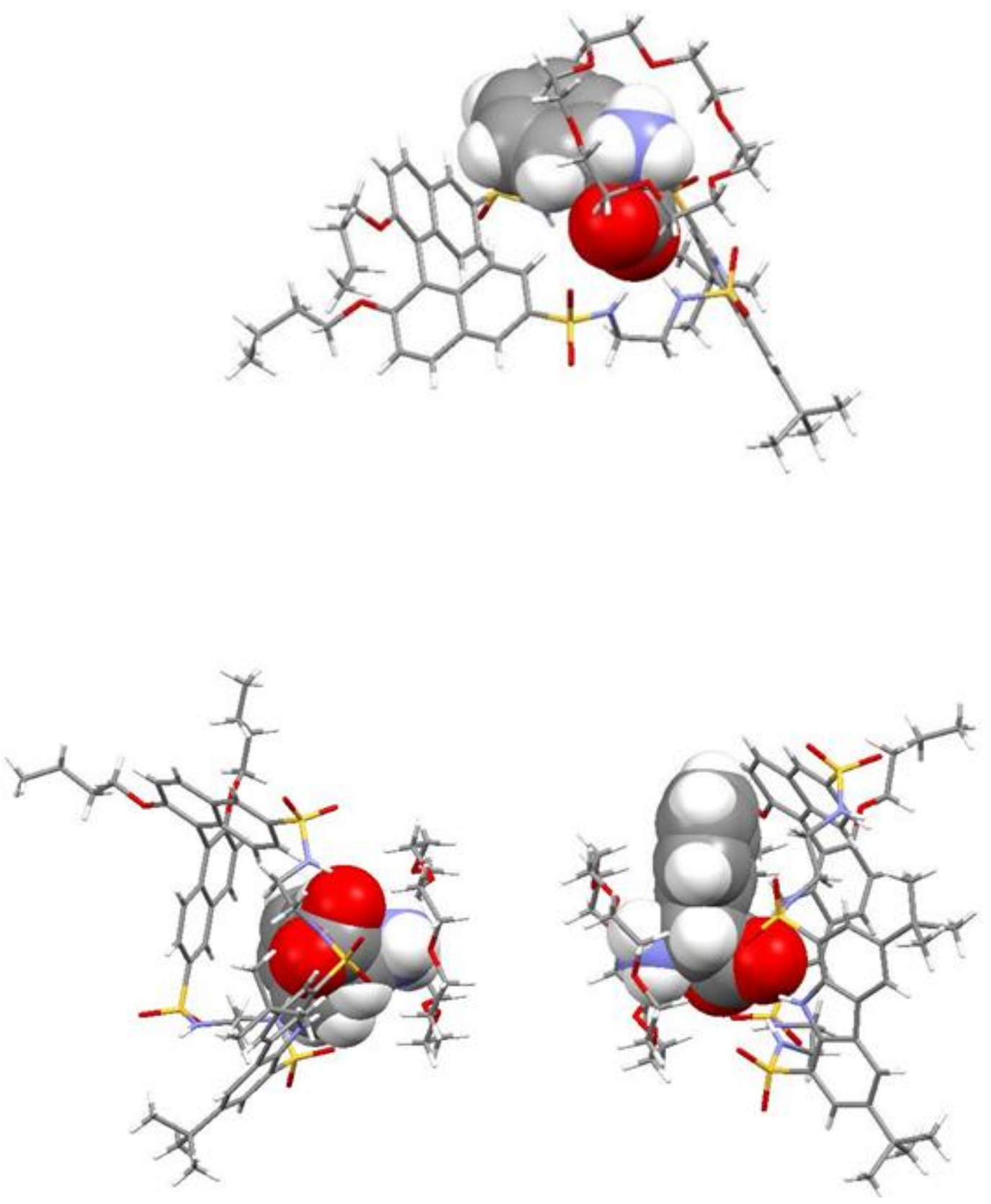

Figure S47. Representations of the X-ray crystal structure of the 1:1:1 ternary complex formed by macrocycle $(S)$-2, 18-crown-6 ether and D-phenylglycine: D-phenylglycine is displayed as space filling model and 18-crown-6-ether and macrocycle are shown in stick model. a) Top view. b) Side views. 

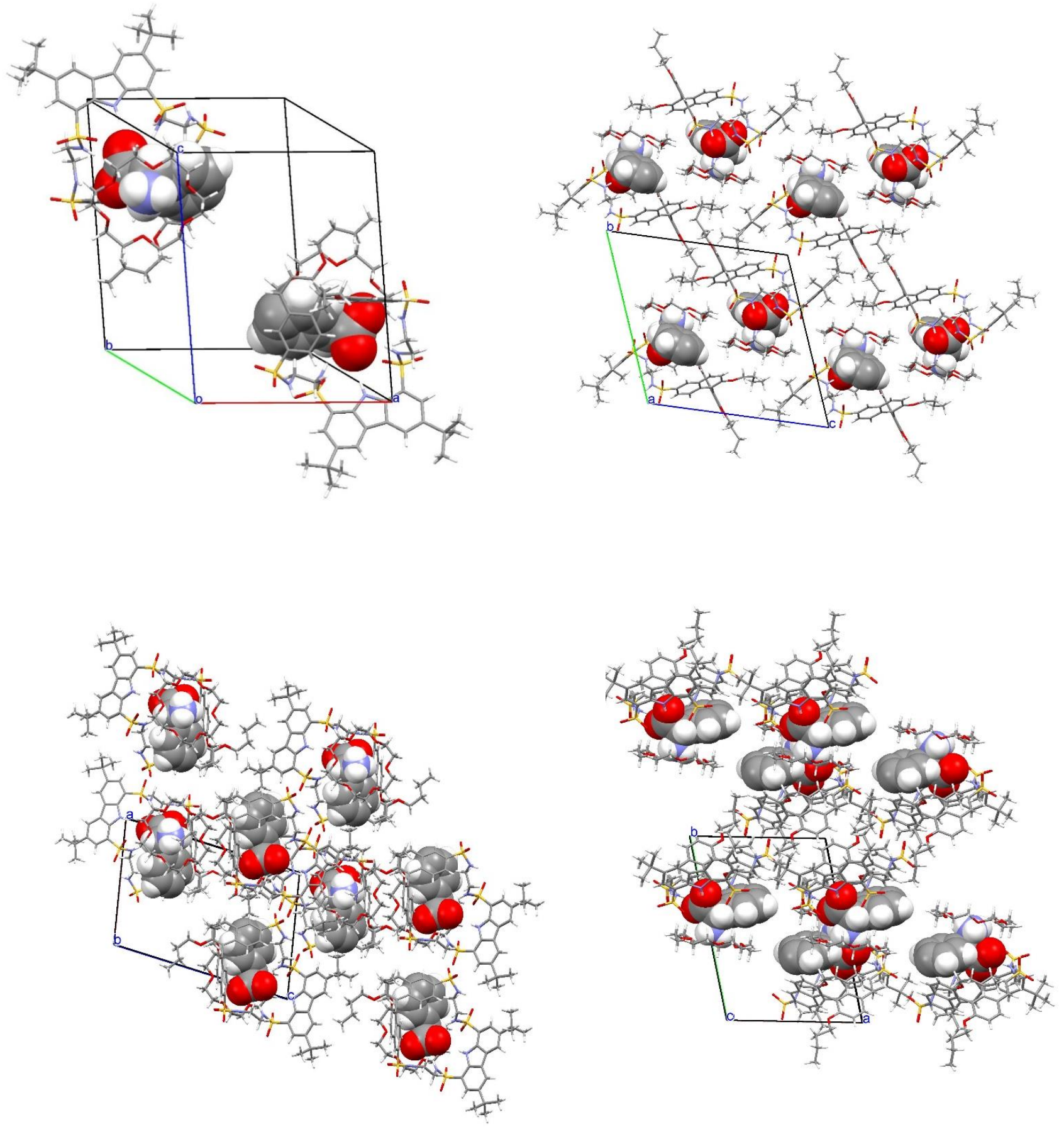

Figure S48. Different representations of the molecular packing: unit cell and projections down the a, b and $\mathrm{c}$ axis. 


\section{MODELIZATION STUDIES}

All calculations were done using Gaussian $16^{[7]}$ software. Geometry optimizations were performed in the gas phase using the M06-2X ${ }^{[8]}$ functional, along with 6-31G(d,p)[9] basis set. Grimme's dispersion ${ }^{[10]}$ term was included by means of the "empiricaldispersion=GD3" keyword. Gibbs free energy correction was calculated at the same level of theory employed during the optimization. A quasiharmonic rotor approximation was used, as suggested by Grimme ${ }^{[11]}$, as it is implemented in "Goodvibes" Software ${ }^{[12]}$ developed by Robert Paton and Funes-Ardoiz. The default settings $(100 \mathrm{~cm}-$ 1 cutoff) were used. This correction to the Gibbs free energy was added to the single point energy calculated at the M06-2X-D3/6-311+G(d,p) level of theory in which solvent effects (chloroform) were included by means if an implicit $\mathrm{SMD}^{[7]}$ solvation model.

In addition to the geometry obtained from the X-ray diffraction experiments, an alternative geometry was considered for the receptor in which the four $\mathrm{NH}$ sulfonamides were directed toward the cavity. This was accomplished by establishing a gauche conformation in the ethylenediamine moiety instead of the alternated conformation shown in the X-ray diffraction structure (see Figure 3). The energies of the complexes are larger with this alternative geometry in all structures, except for the structure of the $(S)-2 \cdot$ L-phenylglycine complex in which the gap toward the binaphthyl sheet is occupied by the phenyl ring. However, the energy of this structure is large compared with the other $(S)$-2• L-phenylglycine complex in which the gap is occupied by the crown ether. A third set of structures was also sought, in which the gauche/alternate configurations of the ethylenediamine moieties are reversed with respect to the most stable structures. The energies are, however, considerably larger in all cases, and therefore these structures were not sought for the complexes with phenylalanine.

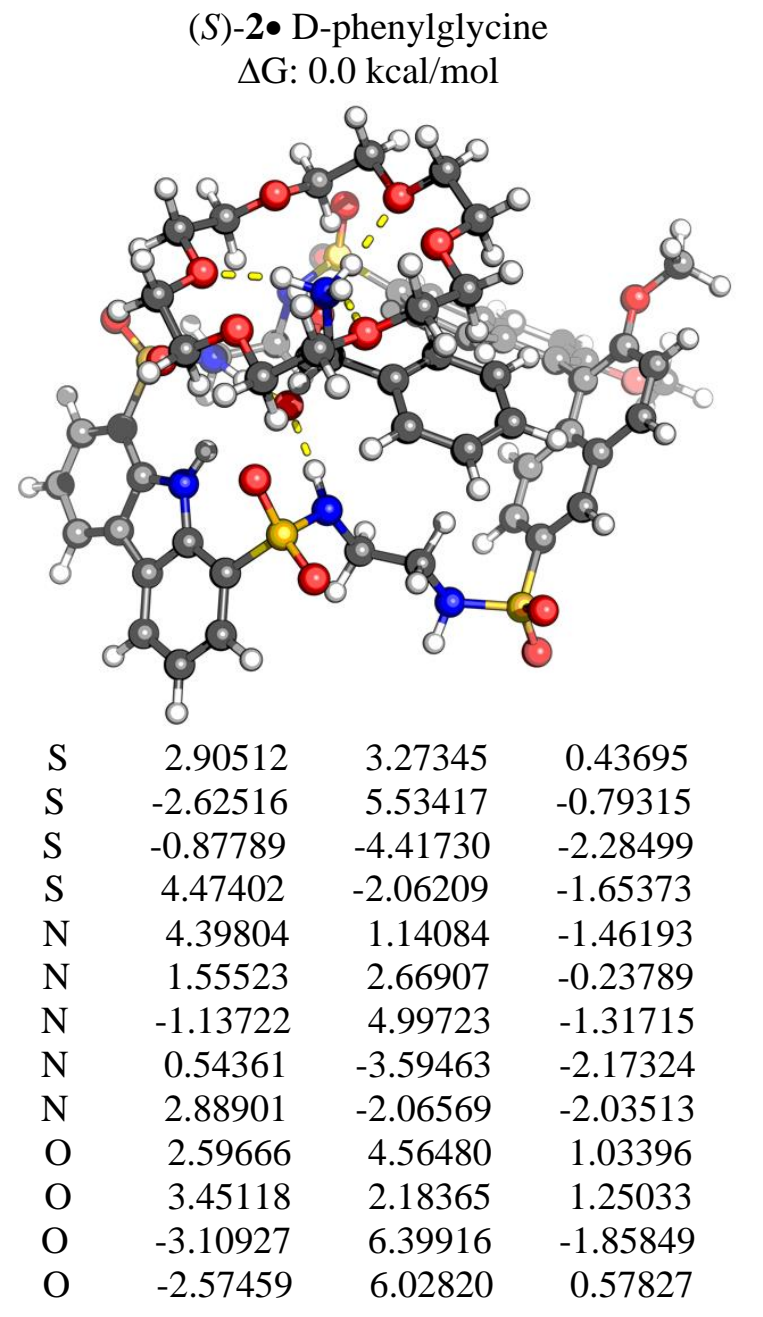

$\begin{array}{lrrr}\mathrm{O} & -0.97245 & -5.23447 & -1.08361 \\ \mathrm{O} & -0.93724 & -5.02168 & -3.60777 \\ \mathrm{O} & 4.55290 & -1.51126 & -0.30297 \\ \mathrm{O} & 5.02920 & -3.36950 & -1.96749 \\ \mathrm{O} & -6.97817 & -1.14684 & 0.57483 \\ \mathrm{O} & -7.68801 & -0.04659 & -2.22170 \\ \mathrm{C} & 4.35199 & 4.86692 & -1.26894 \\ \mathrm{C} & 5.18123 & 5.10964 & -2.37142 \\ \mathrm{C} & 5.69183 & 4.05436 & -3.11486 \\ \mathrm{C} & 5.38337 & 2.74347 & -2.74872 \\ \mathrm{C} & 5.73267 & 1.44589 & -3.28575 \\ \mathrm{C} & 6.50548 & 1.02371 & -4.36953 \\ \mathrm{C} & 6.65207 & -0.33437 & -4.61552 \\ \mathrm{C} & 6.03535 & -1.27942 & -3.78438 \\ \mathrm{C} & 5.26601 & -0.87450 & -2.70393 \\ \mathrm{C} & 5.10440 & 0.49335 & -2.45171 \\ \mathrm{C} & 4.55735 & 2.49608 & -1.62662 \\ \mathrm{C} & 4.03758 & 3.56859 & -0.89147 \\ \mathrm{C} & 0.75518 & 3.49403 & -1.12834 \\ \mathrm{C} & -0.32887 & 4.24010 & -0.35877 \\ \mathrm{C} & -3.51308 & 3.99778 & -0.75455 \\ \mathrm{C} & -4.27814 & 3.72534 & 0.34437 \\ \mathrm{C} & -4.99298 & 2.50341 & 0.41826 \\ \mathrm{C} & -5.77926 & 2.17992 & 1.54716 \\ \mathrm{C} & -6.44175 & 0.98124 & 1.62616 \\ \mathrm{C} & -6.34506 & 0.05023 & 0.56201 \\ \mathrm{C} & -5.57977 & 0.32713 & -0.56272 \\ \mathrm{C} & -4.89332 & 1.56626 & -0.65025 \\ \mathrm{C} & -4.09684 & 1.90657 & -1.78538\end{array}$




\begin{tabular}{|c|c|c|c|}
\hline $\mathrm{C}$ & -3.42637 & 3.09633 & -1.84517 \\
\hline $\mathrm{C}$ & -5.51837 & -0.67797 & -1.65907 \\
\hline $\mathrm{C}$ & -6.62360 & -0.84641 & -2.47901 \\
\hline $\mathrm{C}$ & -6.61726 & -1.80630 & -3.52100 \\
\hline $\mathrm{C}$ & -5.51497 & -2.59843 & -3.71214 \\
\hline $\mathrm{C}$ & -4.37536 & -2.47641 & -2.88492 \\
\hline $\mathrm{C}$ & -3.25444 & -3.33163 & -3.04293 \\
\hline $\mathrm{C}$ & -2.18602 & -3.21088 & -2.19852 \\
\hline $\mathrm{C}$ & -2.14692 & -2.22007 & -1.18509 \\
\hline $\mathrm{C}$ & -3.21339 & -1.37814 & -1.02747 \\
\hline $\mathrm{C}$ & -4.37265 & -1.49570 & -1.85058 \\
\hline $\mathrm{C}$ & 0.92225 & -2.71429 & -3.27398 \\
\hline $\mathrm{C}$ & 2.43965 & -2.58885 & -3.31886 \\
\hline $\mathrm{C}$ & -7.81646 & -1.45252 & 1.66797 \\
\hline $\mathrm{C}$ & -8.84671 & -0.19599 & -3.01342 \\
\hline $\mathrm{N}$ & 1.31802 & -1.37777 & 2.82062 \\
\hline $\mathrm{H}$ & 0.53360 & -2.03226 & 2.67596 \\
\hline $\mathrm{H}$ & 2.19659 & -1.91725 & 2.69172 \\
\hline $\mathrm{H}$ & 1.28357 & -1.00984 & 3.78029 \\
\hline $\mathrm{O}$ & 0.77550 & -1.91097 & 0.26772 \\
\hline $\mathrm{O}$ & 1.80160 & -0.05467 & -0.46534 \\
\hline $\mathrm{C}$ & 0.15719 & 1.92469 & 2.52340 \\
\hline $\mathrm{C}$ & -0.98155 & 2.69863 & 2.73036 \\
\hline $\mathrm{C}$ & -2.24341 & 2.15707 & 2.49324 \\
\hline $\mathrm{C}$ & -2.36618 & 0.84350 & 2.04126 \\
\hline $\mathrm{C}$ & -1.22509 & 0.06768 & 1.83920 \\
\hline $\mathrm{C}$ & 0.04245 & 0.60480 & 2.08445 \\
\hline $\mathrm{C}$ & 1.28315 & -0.23695 & 1.86501 \\
\hline $\mathrm{C}$ & 1.30110 & -0.79558 & 0.43005 \\
\hline $\mathrm{O}$ & -0.68822 & -1.28402 & 4.99280 \\
\hline $\mathrm{O}$ & -0.82927 & -3.36803 & 3.06148 \\
\hline $\mathrm{O}$ & 1.68843 & -4.24434 & 2.04537 \\
\hline $\mathrm{O}$ & 3.80906 & -2.49787 & 2.17227 \\
\hline $\mathrm{O}$ & 3.80875 & -0.33116 & 3.88360 \\
\hline $\mathrm{O}$ & 1.40402 & 0.55412 & 4.99440 \\
\hline $\mathrm{C}$ & 0.41314 & 0.55699 & 5.99841 \\
\hline $\mathrm{C}$ & -0.88491 & 0.04748 & 5.42085 \\
\hline $\mathrm{C}$ & -1.89742 & -1.90692 & 4.61925 \\
\hline $\mathrm{C}$ & -1.61293 & -3.33628 & 4.23182 \\
\hline $\mathrm{C}$ & -0.55763 & -4.70080 & 2.64756 \\
\hline $\mathrm{C}$ & 0.44908 & -4.68240 & 1.52986 \\
\hline $\mathrm{C}$ & 2.69328 & -4.25650 & 1.04935 \\
\hline $\mathrm{C}$ & 3.98676 & -3.81145 & 1.67850 \\
\hline $\mathrm{C}$ & 5.01682 & -1.89433 & 2.57889 \\
\hline $\mathrm{C}$ & 4.75539 & -0.43278 & 2.83299 \\
\hline $\mathrm{C}$ & 3.65142 & 0.99255 & 4.34249 \\
\hline $\mathrm{C}$ & 2.66350 & 0.97583 & 5.48184 \\
\hline $\mathrm{H}$ & 3.94227 & 5.68271 & -0.68234 \\
\hline $\mathrm{H}$ & 5.41822 & 6.13166 & -2.64412 \\
\hline $\mathrm{H}$ & 6.32662 & 4.24562 & -3.97492 \\
\hline $\mathrm{H}$ & 6.98876 & 1.75361 & -5.01206 \\
\hline $\mathrm{H}$ & 7.25315 & -0.67192 & -5.45208 \\
\hline $\mathrm{H}$ & 6.16141 & -2.34411 & -3.95340 \\
\hline $\mathrm{H}$ & -7.04027 & 0.75476 & 2.49986 \\
\hline $\mathrm{H}$ & -8.23593 & -2.43557 & 1.45757 \\
\hline
\end{tabular}

\begin{tabular}{|c|c|c|c|}
\hline $\mathrm{H}$ & -7.25336 & -1.49585 & 2.60784 \\
\hline $\mathrm{H}$ & -8.62946 & -0.72379 & 1.76544 \\
\hline $\mathrm{H}$ & -9.26698 & -1.20442 & -2.92305 \\
\hline $\mathrm{H}$ & -9.56467 & 0.52904 & -2.63186 \\
\hline $\mathrm{H}$ & -8.64384 & 0.01998 & -4.06868 \\
\hline $\mathrm{H}$ & -7.48022 & -1.92394 & -4.16442 \\
\hline $\mathrm{H}$ & -5.51074 & -3.34231 & -4.50368 \\
\hline $\mathrm{H}$ & -3.24924 & -4.09215 & -3.8189 \\
\hline $\mathrm{H}$ & -3.18304 & -0.60519 & -0.2658 \\
\hline $\mathrm{H}$ & -1.26560 & -2.12397 & -0.5538 \\
\hline $\mathrm{H}$ & -5.85618 & 2.89867 & 2.35858 \\
\hline $\mathrm{H}$ & -4.31562 & 4.43635 & 1.16511 \\
\hline $\mathrm{H}$ & -4.02888 & 1.20069 & -2.60615 \\
\hline $\mathrm{H}$ & -2.81251 & 3.35644 & -2.70080 \\
\hline $\mathrm{H}$ & -0.97915 & 3.50564 & 0.12901 \\
\hline $\mathrm{H}$ & 0.11447 & 4.86956 & 0.42069 \\
\hline $\mathrm{H}$ & 0.29021 & 2.83758 & -1.86837 \\
\hline $\mathrm{H}$ & 1.39072 & 4.20283 & -1.68028 \\
\hline $\mathrm{H}$ & 2.88632 & -3.57580 & -3.46021 \\
\hline $\mathrm{H}$ & 2.72997 & -1.93788 & -4.1567 \\
\hline $\mathrm{H}$ & 0.56754 & -3.15799 & -4.20717 \\
\hline $\mathrm{H}$ & 0.46792 & -1.71808 & -3.16439 \\
\hline $\mathrm{H}$ & -1.08570 & -3.84022 & 5.05558 \\
\hline $\mathrm{H}$ & -2.56737 & -3.85912 & 4.06445 \\
\hline $\mathrm{H}$ & -2.36647 & -1.37083 & 3.78242 \\
\hline $\mathrm{H}$ & -2.60201 & -1.90305 & 5.46636 \\
\hline $\mathrm{H}$ & -0.16200 & -5.27483 & 3.49825 \\
\hline $\mathrm{H}$ & -1.48513 & -5.17543 & 2.29702 \\
\hline $\mathrm{H}$ & 0.53472 & -5.69188 & 1.10243 \\
\hline $\mathrm{H}$ & 0.09966 & -4.01559 & 0.73744 \\
\hline $\mathrm{H}$ & 2.81694 & -5.26980 & 0.63772 \\
\hline $\mathrm{H}$ & 2.43439 & -3.57459 & 0.22786 \\
\hline $\mathrm{H}$ & 4.77515 & -3.81639 & 0.91362 \\
\hline $\mathrm{H}$ & 4.27134 & -4.48300 & 2.50233 \\
\hline $\mathrm{H}$ & 5.76423 & -1.98975 & 1.78151 \\
\hline $\mathrm{H}$ & 5.39126 & -2.37864 & 3.49359 \\
\hline $\mathrm{H}$ & 5.69580 & 0.06227 & 3.11958 \\
\hline $\mathrm{H}$ & 4.37928 & 0.04691 & 1.91856 \\
\hline $\mathrm{H}$ & 4.61104 & 1.38924 & 4.71029 \\
\hline $\mathrm{H}$ & 3.30601 & 1.65093 & 3.53322 \\
\hline $\mathrm{H}$ & 3.01054 & 0.28772 & 6.26682 \\
\hline $\mathrm{H}$ & 2.58099 & 1.98477 & 5.91281 \\
\hline $\mathrm{H}$ & 0.72345 & -0.08801 & 6.83427 \\
\hline $\mathrm{H}$ & 0.26444 & 1.57701 & 6.38433 \\
\hline $\mathrm{H}$ & -1.21225 & 0.68015 & 4.58513 \\
\hline $\mathrm{H}$ & -1.65499 & 0.08645 & 6.20798 \\
\hline $\mathrm{H}$ & -0.66058 & 5.77728 & -1.76550 \\
\hline $\mathrm{H}$ & 1.58997 & 1.64049 & -0.37024 \\
\hline $\mathrm{H}$ & 2.39002 & -1.25195 & -1.63098 \\
\hline $\mathrm{H}$ & 3.88619 & 0.67973 & -0.70992 \\
\hline $\mathrm{H}$ & 0.69773 & -3.17307 & -1.24918 \\
\hline $\mathrm{H}$ & 2.17767 & 0.36441 & 2.03378 \\
\hline $\mathrm{H}$ & -0.88411 & 3.72819 & 3.06066 \\
\hline $\mathrm{H}$ & 1.14411 & 2.34337 & 2.69830 \\
\hline $\mathrm{H}$ & -3.13209 & 2.75676 & 2.6595 \\
\hline
\end{tabular}




$\begin{array}{rrrr}\mathrm{H} & -3.35417 & 0.42676 & 1.85155 \\ \mathrm{H} & -1.31237 & -0.96461 & 1.50215\end{array}$

(S)-2•D-phenylglycine

(alternative, gauche conformations for both ethylenediamine)

$\Delta \mathrm{G}: 1.8 \mathrm{kcal} / \mathrm{mol}$

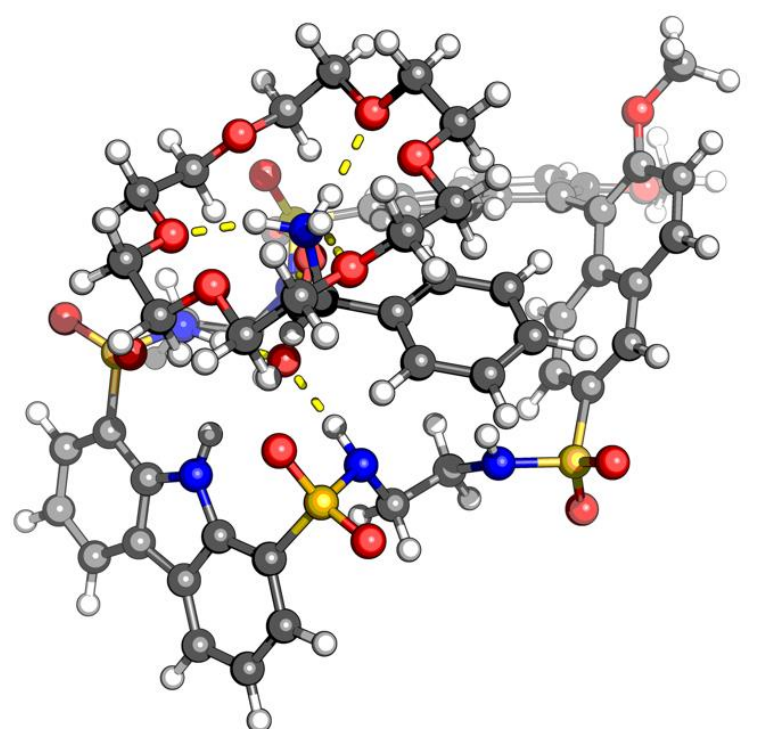

C

$\mathrm{H}$

C

C

C

C

$\mathrm{H}$

$\mathrm{C}$

$\mathrm{H}$

H

C

C

C

C

$\mathrm{H}$

C

$\mathrm{H}$

C

C

C

$\mathrm{C}$

$\mathrm{C}$

$\mathrm{C}$

C

C

C

$$
\text { C }
$$$$
\text { C }
$$$$
\text { C }
$$$$
\text { C }
$$

$\mathrm{C}$

C

C

C$$
\text { C }
$$$$
\text { C }
$$$$
\text { C }
$$$$
\mathrm{H}
$$$$
\mathrm{H}
$$$$
\text { C }
$$$$
\text { H }
$$

,

C

$\mathrm{H}$

\begin{tabular}{|c|c|c|}
\hline-6.09112 & 0.49184 & -3.23948 \\
\hline-6.85169 & 1.40131 & -3.97716 \\
\hline-7.39909 & 1.06987 & -4.85450 \\
\hline-6.90783 & 2.72825 & -3.57523 \\
\hline-6.21646 & 3.15533 & -2.43353 \\
\hline-6.28083 & 4.18249 & -2.08880 \\
\hline-5.45369 & 2.26416 & -1.69291 \\
\hline-5.37711 & 0.92526 & -2.09860 \\
\hline-4.96922 & -1.26338 & -2.29385 \\
\hline-4.52114 & -2.58178 & -2.14751 \\
\hline-1.48469 & -2.49713 & -2.82064 \\
\hline-1.93585 & -1.76938 & -3.50823 \\
\hline-1.79846 & -3.50260 & -3.11563 \\
\hline 0.03336 & -2.42610 & -2.90478 \\
\hline 0.33912 & -2.54298 & -3.94791 \\
\hline 0.38397 & -1.45003 & -2.53770 \\
\hline 3.32044 & -3.04384 & -2.12264 \\
\hline 4.23650 & -3.37934 & -1.16504 \\
\hline 4.22318 & -4.37562 & -0.73194 \\
\hline 5.18228 & -2.41677 & -0.72159 \\
\hline 6.12052 & -2.71658 & 0.29315 \\
\hline 6.14967 & -3.72262 & 0.70201 \\
\hline 6.97807 & -1.75750 & 0.76788 \\
\hline 7.68477 & -2.01139 & 1.54828 \\
\hline 6.92207 & -0.43659 & 0.25568 \\
\hline 6.02527 & -0.09983 & -0.74712 \\
\hline 5.15635 & -1.10079 & -1.26736 \\
\hline 4.23768 & -0.82728 & -2.32545 \\
\hline 4.25434 & 0.14767 & -2.79866 \\
\hline 3.34577 & -1.77225 & -2.74803 \\
\hline 2.66779 & -1.56085 & -3.56861 \\
\hline 5.93630 & 1.29840 & -1.24759 \\
\hline 6.97866 & 1.84673 & -1.98077 \\
\hline 6.86378 & 3.14137 & -2.54621 \\
\hline 7.68157 & 3.56457 & -3.11618 \\
\hline 5.69948 & 3.85223 & -2.40322 \\
\hline 5.59978 & 4.82958 & -2.86646 \\
\hline 4.60990 & 3.33010 & -1.67028 \\
\hline 3.37123 & 4.02246 & -1.58581 \\
\hline 3.23122 & 4.96424 & -2.10890 \\
\hline 2.34072 & 3.47197 & -0.88043 \\
\hline 2.48211 & 2.24557 & -0.18251 \\
\hline 1.64444 & 1.84245 & 0.38173 \\
\hline 3.65918 & 1.55928 & -0.27181 \\
\hline 3.76859 & 0.60978 & 0.24138 \\
\hline 4.74845 & 2.05563 & -1.04959 \\
\hline-1.32687 & 3.36635 & -2.27309 \\
\hline-0.98022 & 4.10134 & -3.00209 \\
\hline-1.58436 & 2.44525 & -2.80768 \\
\hline-2.56424 & 3.89385 & -1.55565 \\
\hline-3.34254 & 4.09830 & -2.30463 \\
\hline-2.33823 & 4.82775 & -1.03157 \\
\hline 8.68787 & 0.25348 & 1.68760 \\
\hline 9.39720 & -0.49140 & 1.30864 \\
\hline 8.24104 & -0.11282 & 2.61957 \\
\hline
\end{tabular}




\begin{tabular}{|c|c|c|c|}
\hline $\mathrm{C}$ & 9.16152 & 1.58150 & -2.88350 \\
\hline $\mathrm{H}$ & 9.57072 & 2.48705 & -2.42038 \\
\hline $\mathrm{H}$ & 8.87701 & 1.80091 & -3.91920 \\
\hline $\mathrm{O}$ & -0.42969 & 1.34421 & 0.93455 \\
\hline $\mathrm{O}$ & -1.98503 & 0.29217 & -0.28640 \\
\hline $\mathrm{N}$ & -1.05273 & -0.04422 & 3.1328 \\
\hline $\mathrm{H}$ & -1.07714 & -0.77199 & 3.85 \\
\hline $\mathrm{H}$ & -1.78396 & 0.66953 & 3.322 \\
\hline $\mathrm{H}$ & -0.14297 & 0.43993 & $3.164 \mathrm{C}$ \\
\hline $\mathrm{C}$ & -0.64499 & -3.08408 & 1.4076 \\
\hline $\mathrm{H}$ & -1.69186 & -3.35802 & 1.492 \\
\hline $\mathrm{C}$ & 0.31788 & -4.06209 & 1.16530 \\
\hline $\mathrm{H}$ & 0.01688 & -5.09783 & 1.0435 \\
\hline $\mathrm{C}$ & 1.66239 & -3.70585 & $1.0481 \mathrm{~S}$ \\
\hline $\mathrm{H}$ & 2.40227 & -4.46984 & 0.8329 \\
\hline $\mathrm{C}$ & 2.03704 & -2.36788 & 1.16685 \\
\hline $\mathrm{H}$ & 3.08102 & -2.08390 & 1.0615 \\
\hline $\mathrm{C}$ & 1.07313 & -1.39064 & 1.40878 \\
\hline $\mathrm{H}$ & 1.36299 & -0.34606 & 1.5090 \\
\hline $\mathrm{C}$ & -0.27280 & -1.74421 & 1.5341 \\
\hline $\mathrm{C}$ & -1.30935 & -0.67347 & 1.8078 \\
\hline $\mathrm{H}$ & -2.30905 & -1.10569 & 1.8313 \\
\hline $\mathrm{C}$ & -1.24612 & 0.42536 & 0.73087 \\
\hline $\mathrm{O}$ & 1.49540 & 1.15373 & 3.9705 \\
\hline $\mathrm{O}$ & 0.88423 & -1.48309 & 4.8849 \\
\hline $\mathrm{O}$ & -1.56099 & -2.66983 & 4.3051 \\
\hline $\mathrm{O}$ & -3.69113 & -0.92854 & 3.9214 \\
\hline $\mathrm{O}$ & -3.20792 & 1.72245 & 3.0873 \\
\hline $\mathrm{O}$ & -0.75301 & 2.87541 & 3.5595 \\
\hline $\mathrm{C}$ & 2.23751 & 0.46712 & 4.95280 \\
\hline $\mathrm{H}$ & 1.82024 & 0.66430 & 5.95173 \\
\hline $\mathrm{H}$ & 3.28397 & 0.80948 & 4.94450 \\
\hline $\mathrm{C}$ & 2.19891 & -1.01465 & 4.67936 \\
\hline $\mathrm{H}$ & 2.52605 & -1.22059 & 3.65054 \\
\hline $\mathrm{H}$ & 2.89336 & -1.52194 & 5.36814 \\
\hline $\mathrm{C}$ & 0.78142 & -2.87634 & 4.67838 \\
\hline $\mathrm{H}$ & 1.52550 & -3.40990 & 5.29116 \\
\hline $\mathrm{H}$ & 0.95911 & -3.12456 & 3.6238 \\
\hline $\mathrm{C}$ & -0.59694 & -3.31952 & 5.10407 \\
\hline $\mathrm{H}$ & -0.67932 & -4.41098 & 4.98872 \\
\hline $\mathrm{H}$ & -0.75676 & -3.06899 & 6.1636 \\
\hline $\mathrm{C}$ & -2.88236 & -3.01604 & 4.6701 \\
\hline $\mathrm{H}$ & -3.07603 & -2.71000 & 5.7089 \\
\hline $\mathrm{H}$ & -3.02200 & -4.10487 & 4.59486 \\
\hline $\mathrm{C}$ & -3.84674 & -2.31806 & 3.74411 \\
\hline $\mathrm{H}$ & -3.66436 & -2.60363 & 2.69711 \\
\hline $\mathrm{H}$ & -4.87234 & -2.62695 & 4.0015 \\
\hline $\mathrm{C}$ & -4.62228 & -0.18301 & 3.1549 \\
\hline $\mathrm{H}$ & -5.64747 & -0.51284 & 3.38282 \\
\hline $\mathrm{H}$ & -4.44414 & -0.32006 & 2.0787 \\
\hline $\mathrm{C}$ & -4.47680 & 1.27199 & 3.51751 \\
\hline $\mathrm{H}$ & -5.26274 & 1.84575 & 3.0148 \\
\hline $\mathrm{H}$ & -4.56933 & 1.39833 & 4.60703 \\
\hline $\mathrm{C}$ & -3.07315 & 3.12982 & 3.1812 \\
\hline $\mathrm{H}$ & -3.22631 & 3.44394 & 4.2249 \\
\hline
\end{tabular}

$\begin{array}{rrrr}\mathrm{H} & -3.82760 & 3.61699 & 2.54642 \\ \mathrm{C} & -1.69382 & 3.51811 & 2.71560 \\ \mathrm{H} & -1.54025 & 3.22300 & 1.67199 \\ \mathrm{H} & -1.58319 & 4.61122 & 2.78136 \\ \mathrm{C} & 0.57107 & 3.22848 & 3.22411 \\ \mathrm{H} & 0.70831 & 4.31874 & 3.28602 \\ \mathrm{H} & 0.80326 & 2.92735 & 2.19827 \\ \mathrm{C} & 1.50153 & 2.55576 & 4.19740 \\ \mathrm{H} & 2.52221 & 2.94471 & 4.06694 \\ \mathrm{H} & 1.17569 & 2.76315 & 5.22728 \\ \mathrm{H} & 9.21581 & 1.18526 & 1.88757 \\ \mathrm{H} & 9.92174 & 0.80089 & -2.87949 \\ \mathrm{H} & -6.14805 & -3.99173 & -4.77620 \\ \mathrm{H} & -7.49918 & 3.44150 & -4.13790\end{array}$

(S)-2• D-phenylglycine (alternative) $\Delta \mathrm{G}: 13.4 \mathrm{kcal} / \mathrm{mol}$

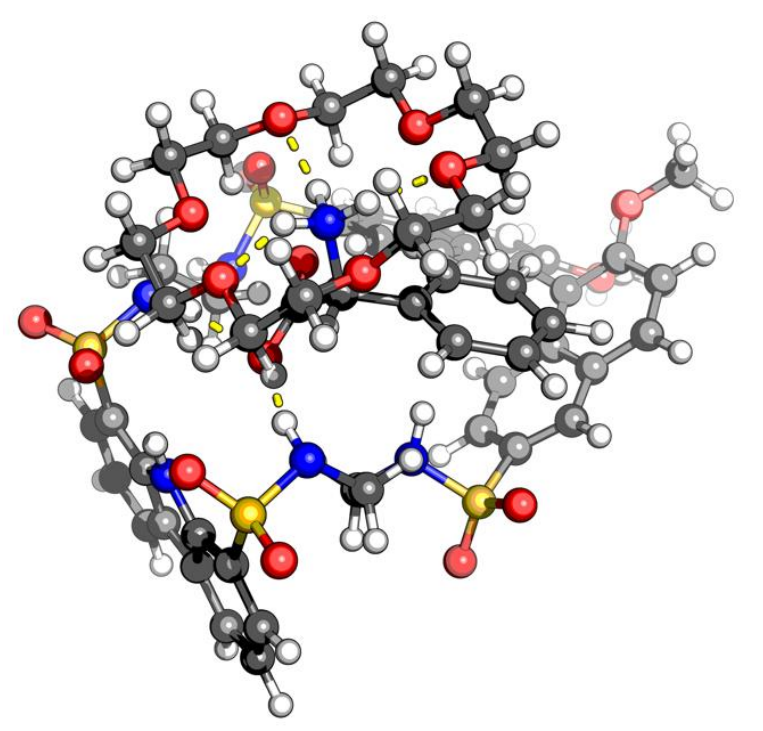

$\begin{array}{lrrr}\mathrm{S} & 4.80674 & -1.59415 & 2.15010 \\ \mathrm{~S} & -0.75840 & -1.53706 & 4.14648 \\ \mathrm{~S} & -1.64027 & 3.98772 & -2.43367 \\ \mathrm{~S} & 4.21330 & 3.25065 & -1.11350 \\ \mathrm{~N} & 4.41425 & 1.49821 & 1.58075 \\ \mathrm{H} & 4.75663 & 1.01127 & 0.75774 \\ \mathrm{~N} & 3.25116 & -1.79744 & 1.62240 \\ \mathrm{H} & 3.00623 & -1.05308 & 0.94461 \\ \mathrm{~N} & 0.03303 & -0.76557 & 2.89464 \\ \mathrm{H} & -0.27448 & -1.15512 & 2.00059 \\ \mathrm{~N} & -0.53459 & 4.43321 & -1.27882 \\ \mathrm{H} & -0.34354 & 5.42650 & -1.36852 \\ \mathrm{~N} & 2.79807 & 2.70010 & -1.74094 \\ \mathrm{H} & 2.51780 & 1.80432 & -1.31837 \\ \mathrm{O} & 5.21268 & -2.79126 & 2.86516 \\ \mathrm{O} & 5.54176 & -1.11518 & 0.98067 \\ \mathrm{O} & -0.61279 & -2.99163 & 4.10168 \\ \mathrm{O} & -0.38053 & -0.82980 & 5.36191 \\ \mathrm{O} & -1.04652 & 3.01690 & -3.34783\end{array}$




\begin{tabular}{|c|c|c|c|c|c|c|c|}
\hline $\mathrm{O}$ & -2.20368 & 5.23680 & -2.92664 & $\mathrm{H}$ & -3.46053 & 0.12925 & -0.05615 \\
\hline $\mathrm{O}$ & 5.09718 & 2.08798 & -1.05202 & $\mathrm{C}$ & -4.89789 & 1.76234 & -0.11291 \\
\hline $\mathrm{O}$ & 4.57730 & 4.44644 & -1.85528 & $\mathrm{C}$ & 0.59925 & 3.56226 & -0.96669 \\
\hline $\mathrm{O}$ & -7.46905 & -0.98138 & -0.15249 & $\mathrm{H}$ & 0.96383 & 3.83331 & 0.02959 \\
\hline $\mathrm{O}$ & -8.01879 & 1.14183 & 1.65828 & $\mathrm{H}$ & 0.25171 & 2.52616 & -0.91980 \\
\hline $\mathrm{C}$ & 4.62036 & -0.53438 & 4.68661 & $\mathrm{C}$ & 1.72169 & 3.65692 & -2.00277 \\
\hline $\mathrm{H}$ & 4.82487 & -1.54294 & 5.03227 & $\mathrm{H}$ & 2.15458 & 4.66284 & -2.03051 \\
\hline $\mathrm{C}$ & 4.27181 & 0.48306 & 5.58495 & $\mathrm{H}$ & 1.30568 & 3.46063 & -2.99452 \\
\hline C & 3.96697 & 1.76046 & 5.12832 & $\mathrm{C}$ & -8.35007 & -1.99687 & -0.57989 \\
\hline $\mathrm{H}$ & 3.66471 & 2.53329 & 5.82848 & $\mathrm{H}$ & -8.92317 & -2.40944 & 0.25864 \\
\hline C & 4.04429 & 2.03898 & 3.76261 & $\mathrm{H}$ & -7.81509 & -2.80839 & -1.08723 \\
\hline $\mathrm{C}$ & 3.79688 & 3.21205 & 2.94809 & $\mathrm{C}$ & -9.26646 & 1.75843 & 1.89204 \\
\hline C & 3.41012 & 4.52287 & 3.22581 & $\mathrm{H}$ & -9.80474 & 1.93990 & 0.95438 \\
\hline $\mathrm{H}$ & 3.20950 & 4.82876 & 4.24812 & $\mathrm{H}$ & -9.15396 & 2.70402 & 2.43494 \\
\hline $\mathrm{C}$ & 3.29806 & 5.43655 & 2.18439 & $\mathrm{O}$ & 2.13028 & 0.23331 & -0.12532 \\
\hline $\mathrm{C}$ & 3.56876 & 5.05299 & 0.86510 & $\mathrm{O}$ & 0.44143 & 0.41491 & -1.59909 \\
\hline $\mathrm{H}$ & 3.52304 & 5.77461 & 0.05523 & $\mathrm{~N}$ & 1.30750 & -2.01019 & -2.62815 \\
\hline $\mathrm{C}$ & 3.93597 & 3.74636 & 0.56778 & $\mathrm{H}$ & 2.28915 & -1.95021 & -2.93607 \\
\hline C & 4.04844 & 2.82064 & 1.60968 & $\mathrm{H}$ & 0.77740 & -1.28352 & -3.14077 \\
\hline $\mathrm{C}$ & 4.42402 & 1.01619 & 2.86328 & $\mathrm{H}$ & 0.93014 & -2.94111 & -2.85660 \\
\hline $\mathrm{C}$ & 4.69331 & -0.27511 & 3.32476 & $\mathrm{C}$ & 1.28175 & -1.75678 & -1.15912 \\
\hline $\mathrm{C}$ & 2.22245 & -1.97559 & 2.65676 & $\mathrm{C}$ & 1.28594 & -0.22318 & -0.94059 \\
\hline $\mathrm{H}$ & 2.68607 & -2.43013 & 3.53748 & $\mathrm{O}$ & -1.29441 & -2.27469 & -3.76858 \\
\hline $\mathrm{H}$ & 1.49371 & -2.70341 & 2.29240 & $\mathrm{O}$ & 0.12347 & -4.63082 & -3.16924 \\
\hline $\mathrm{C}$ & 1.48984 & -0.65807 & 2.99740 & $\mathrm{O}$ & 2.67722 & -4.47906 & -1.95904 \\
\hline $\mathrm{H}$ & 1.72553 & -0.30119 & 4.00454 & $\mathrm{O}$ & 4.19657 & -2.14289 & -2.44021 \\
\hline $\mathrm{H}$ & 1.78294 & 0.12154 & 2.28625 & $\mathrm{O}$ & 2.93930 & 0.08642 & -3.45497 \\
\hline $\mathrm{C}$ & -2.40025 & -1.13796 & 3.61340 & $\mathrm{O}$ & 0.35301 & -0.15398 & -4.61348 \\
\hline $\mathrm{C}$ & -3.26034 & -2.14819 & 3.29392 & $\mathrm{C}$ & -1.81172 & -3.55344 & -4.04230 \\
\hline $\mathrm{H}$ & -2.99223 & -3.17643 & 3.51984 & $\mathrm{H}$ & -1.51669 & -3.87542 & -5.05304 \\
\hline $\mathrm{C}$ & -4.44120 & -1.85304 & 2.56162 & $\mathrm{H}$ & -2.91251 & -3.54625 & -3.99412 \\
\hline $\mathrm{C}$ & -5.30713 & -2.87781 & 2.12091 & $\mathrm{C}$ & -1.28387 & -4.54198 & -3.02930 \\
\hline $\mathrm{H}$ & -5.13880 & -3.89480 & 2.46548 & $\mathrm{H}$ & -1.54605 & -4.23415 & -2.00783 \\
\hline $\mathrm{C}$ & -6.33434 & -2.60860 & 1.25137 & $\mathrm{H}$ & -1.73974 & -5.52408 & -3.22648 \\
\hline $\mathrm{H}$ & -6.97820 & -3.41268 & 0.91763 & $\mathrm{C}$ & 0.67408 & -5.68796 & -2.40793 \\
\hline $\mathrm{C}$ & -6.52636 & -1.29043 & 0.76898 & $\mathrm{H}$ & 0.29432 & -6.65149 & -2.77972 \\
\hline $\mathrm{C}$ & -5.72253 & -0.24441 & 1.20869 & $\mathrm{H}$ & 0.38895 & -5.58529 & -1.35231 \\
\hline $\mathrm{C}$ & -4.68821 & -0.51363 & 2.14519 & $\mathrm{C}$ & 2.17621 & -5.65896 & -2.54521 \\
\hline $\mathrm{C}$ & -3.83675 & 0.52127 & 2.64143 & $\mathrm{H}$ & 2.59580 & -6.54688 & -2.04687 \\
\hline $\mathrm{H}$ & -4.06997 & 1.55324 & 2.40593 & $\mathrm{H}$ & 2.45277 & -5.70383 & -3.60975 \\
\hline $\mathrm{C}$ & -2.71002 & 0.22089 & 3.34884 & $\mathrm{C}$ & 4.09523 & -4.45351 & -1.97392 \\
\hline $\mathrm{H}$ & -2.02261 & 0.99471 & 3.67268 & $\mathrm{H}$ & 4.45948 & -4.62111 & -2.99848 \\
\hline $\mathrm{C}$ & -5.91592 & 1.12198 & 0.65332 & $\mathrm{H}$ & 4.49235 & -5.24995 & -1.32736 \\
\hline $\mathrm{C}$ & -7.10872 & 1.79137 & 0.89394 & $\mathrm{C}$ & 4.58102 & -3.11161 & -1.48643 \\
\hline $\mathrm{C}$ & -7.33489 & 3.09120 & 0.37772 & $\mathrm{H}$ & 4.16557 & -2.88488 & -0.49500 \\
\hline $\mathrm{H}$ & -8.27255 & 3.59925 & 0.56426 & $\mathrm{H}$ & 5.67566 & -3.13310 & -1.38460 \\
\hline $\mathrm{C}$ & -6.35644 & 3.71629 & -0.34892 & $\mathrm{C}$ & 4.66484 & -0.83154 & -2.13797 \\
\hline $\mathrm{H}$ & -6.52047 & 4.71814 & -0.73486 & $\mathrm{H}$ & 5.74606 & -0.84394 & -1.94735 \\
\hline $\mathrm{C}$ & -5.11745 & 3.08337 & -0.60005 & $\mathrm{H}$ & 4.16173 & -0.44207 & -1.24327 \\
\hline $\mathrm{C}$ & -4.09181 & 3.75087 & -1.31670 & $\mathrm{C}$ & 4.34770 & 0.03368 & -3.32995 \\
\hline $\mathrm{H}$ & -4.24984 & 4.75833 & -1.69054 & $\mathrm{H}$ & 4.75676 & 1.03857 & -3.17315 \\
\hline $\mathrm{C}$ & -2.89914 & 3.12112 & -1.53637 & $\mathrm{H}$ & 4.78969 & -0.40484 & -4.23827 \\
\hline $\mathrm{C}$ & -2.66066 & 1.79564 & -1.09411 & $\mathrm{C}$ & 2.52377 & 0.86524 & -4.55553 \\
\hline $\mathrm{H}$ & -1.70315 & 1.31715 & -1.29716 & $\mathrm{H}$ & 2.79605 & 0.36599 & -5.49876 \\
\hline $\mathrm{C}$ & -3.64458 & 1.13920 & -0.40495 & $\mathrm{H}$ & 3.01868 & 1.84827 & -4.52405 \\
\hline
\end{tabular}




$\begin{array}{lrrr}\mathrm{C} & 1.03606 & 1.08660 & -4.47082 \\ \mathrm{H} & 0.78368 & 1.52560 & -3.50355 \\ \mathrm{H} & 0.71772 & 1.77629 & -5.26670 \\ \mathrm{C} & -1.04083 & 0.00509 & -4.42087 \\ \mathrm{H} & -1.43457 & 0.77774 & -5.09680 \\ \mathrm{H} & -1.24251 & 0.32744 & -3.39077 \\ \mathrm{C} & -1.71012 & -1.31351 & -4.72082 \\ \mathrm{H} & -2.80327 & -1.18926 & -4.68215 \\ \mathrm{H} & -1.43401 & -1.64636 & -5.73269 \\ \mathrm{H} & -9.03271 & -1.52396 & -1.28506 \\ \mathrm{H} & -9.83504 & 1.06022 & 2.50531 \\ \mathrm{H} & 4.21669 & 0.26036 & 6.64418 \\ \mathrm{H} & 3.01464 & 6.46203 & 2.39269 \\ \mathrm{C} & 0.08443 & -2.41301 & -0.50675 \\ \mathrm{C} & 0.29154 & -3.55526 & 0.26992 \\ \mathrm{C} & -1.21566 & -1.90712 & -0.65030 \\ \mathrm{C} & -0.77734 & -4.18796 & 0.90457 \\ \mathrm{H} & 1.30251 & -3.94551 & 0.36868 \\ \mathrm{C} & -2.28383 & -2.54627 & -0.02494 \\ \mathrm{H} & -1.37523 & -1.02588 & -1.26243 \\ \mathrm{C} & -2.06592 & -3.68782 & 0.74701 \\ \mathrm{H} & -0.59848 & -5.05638 & 1.52998 \\ \mathrm{H} & -3.29450 & -2.15954 & -0.13834 \\ \mathrm{H} & -2.90458 & -4.17761 & 1.23138 \\ \mathrm{H} & 2.19157 & -2.19919 & -0.75508\end{array}$

(S)-2• L-phenylglycine

(binaphthyl gap occupied by 18 -crown-6 ether)

$\Delta \mathrm{G}: 7.9 \mathrm{kcal} / \mathrm{mol}$

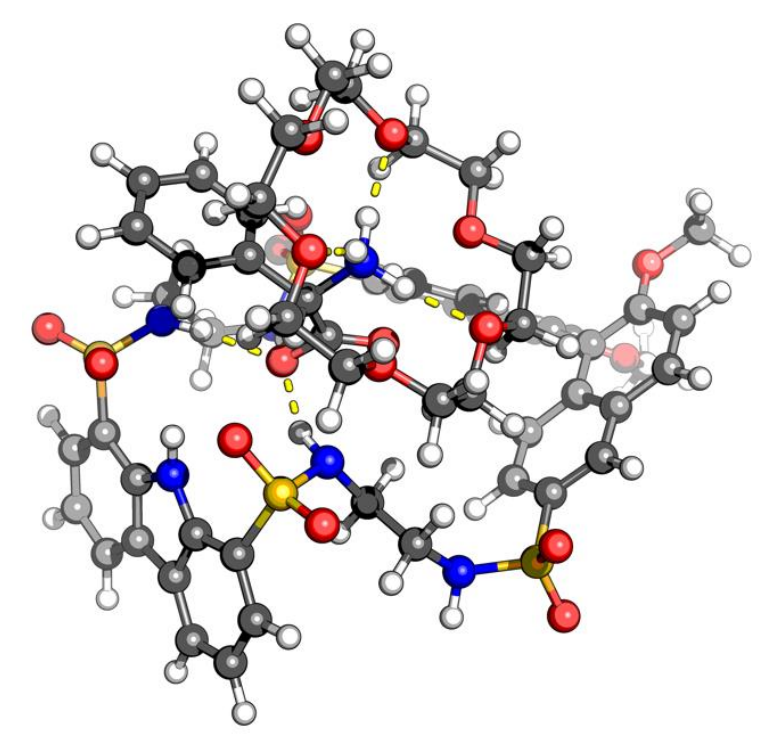

$\begin{array}{lrrr}\mathrm{S} & -1.33646 & 3.14077 & -1.44112 \\ \mathrm{~S} & 4.53687 & 4.63457 & -1.56901 \\ \mathrm{~S} & -0.72416 & -1.75169 & 3.84227 \\ \mathrm{~S} & -5.34896 & -0.18235 & 1.54843 \\ \mathrm{~N} & -3.54523 & 2.41062 & 0.83892 \\ \mathrm{H} & -3.35484 & 1.62021 & 0.22772\end{array}$

\begin{tabular}{|c|c|c|c|}
\hline N & 0.07116 & 2.56198 & 5704 \\
\hline $\mathrm{H}$ & 0.00937 & 1.59578 & -0.50050 \\
\hline $\mathrm{N}$ & 2.99381 & 4.89609 & -1.00343 \\
\hline $\mathrm{H}$ & 2.82713 & 5.89484 & -0.92752 \\
\hline $\mathrm{N}$ & -1.53969 & -0.32968 & 3.56791 \\
\hline $\mathrm{H}$ & -1.52335 & -0.09244 & 2.56651 \\
\hline $\mathrm{N}$ & -4.08255 & -1.06049 & 2.08679 \\
\hline $\mathrm{H}$ & -3.24886 & -0.90624 & 1.50377 \\
\hline $\mathrm{O}$ & -1.04066 & 4.00986 & -2.57644 \\
\hline $\mathrm{O}$ & -2.22069 & 1.98814 & -1.60283 \\
\hline $\mathrm{O}$ & 4.57545 & 4.48079 & -3.01775 \\
\hline $\mathrm{O}$ & 5.34813 & 5.65369 & -0.92206 \\
\hline $\mathrm{O}$ & -1.13607 & -2.79459 & 2.89948 \\
\hline $\mathrm{O}$ & -0.81745 & -2.03005 & 5.27101 \\
\hline $\mathrm{O}$ & -5.09415 & 0.06314 & 0.13021 \\
\hline $\mathrm{O}$ & -6.57779 & -0.81482 & 2.00293 \\
\hline $\mathrm{O}$ & 5.81923 & -3.09774 & 0.43754 \\
\hline $\mathrm{O}$ & 7.23250 & -1.50520 & 2.54989 \\
\hline $\mathrm{C}$ & -1.65560 & 5.49457 & -0.07635 \\
\hline $\mathrm{H}$ & -0.98816 & 5.89830 & -0.83175 \\
\hline $\mathrm{C}$ & -2.13644 & 6.30790 & 0.95519 \\
\hline $\mathrm{C}$ & -3.02847 & 5.80011 & 1.89152 \\
\hline $\mathrm{H}$ & -3.40737 & 6.43359 & 2.68791 \\
\hline $\mathrm{C}$ & -3.45078 & 4.47584 & 1.78934 \\
\hline $\mathrm{C}$ & -4.39095 & 3.66915 & 2.53654 \\
\hline $\mathrm{C}$ & -5.20055 & 3.90864 & 3.64824 \\
\hline $\mathrm{H}$ & -5.17338 & 4.87275 & 4.14733 \\
\hline $\mathrm{C}$ & -6.04605 & 2.90571 & 4.10147 \\
\hline $\mathrm{C}$ & -6.09702 & 1.66682 & 3.44747 \\
\hline $\mathrm{H}$ & -6.78441 & 0.89202 & 3.77184 \\
\hline $\mathrm{C}$ & -5.29114 & 1.40702 & 2.34811 \\
\hline $\mathrm{C}$ & -4.42217 & 2.40839 & 1.89494 \\
\hline $\mathrm{C}$ & -2.95552 & 3.64406 & 0.75145 \\
\hline $\mathrm{C}$ & -2.04468 & 4.16334 & -0.18004 \\
\hline $\mathrm{C}$ & 1.12635 & 3.44851 & -0.39512 \\
\hline $\mathrm{H}$ & 1.81313 & 2.83973 & 0.20074 \\
\hline $\mathrm{H}$ & 0.73469 & 4.23218 & 0.26893 \\
\hline $\mathrm{C}$ & 1.90557 & 4.08094 & -1.55016 \\
\hline $\mathrm{H}$ & 2.33266 & 3.28541 & -2.17063 \\
\hline $\mathrm{H}$ & 1.25005 & 4.66860 & -2.19789 \\
\hline $\mathrm{C}$ & 4.83537 & 3.02937 & -0.87495 \\
\hline $\mathrm{C}$ & 5.25594 & 2.02244 & -1.69801 \\
\hline $\mathrm{H}$ & 5.41087 & 2.21759 & -2.75564 \\
\hline $\mathrm{C}$ & 5.46224 & 0.72264 & -1.16633 \\
\hline $\mathrm{C}$ & 5.91093 & -0.34167 & -1.98032 \\
\hline $\mathrm{H}$ & 6.13074 & -0.14815 & -3.02633 \\
\hline $\mathrm{C}$ & 6.06052 & -1.60520 & -1.46688 \\
\hline $\mathrm{H}$ & 6.40441 & -2.40672 & -2.10879 \\
\hline $\mathrm{C}$ & 5.74240 & -1.86055 & -0.10931 \\
\hline $\mathrm{C}$ & 5.31349 & -0.83947 & 0.73101 \\
\hline $\mathrm{C}$ & 5.19203 & 0.47609 & 0.21158 \\
\hline $\mathrm{C}$ & 4.79216 & 1.57186 & 1.03623 \\
\hline $\mathrm{H}$ & 4.61843 & 1.39455 & 2.09207 \\
\hline $\mathrm{C}$ & 4.62703 & 2.82301 & 0.51270 \\
\hline $\mathrm{H}$ & 4.31799 & 3.65789 & 1.1332 \\
\hline
\end{tabular}




\begin{tabular}{|c|c|c|c|}
\hline $\mathrm{C}$ & 4.96469 & -1.15617 & 2.14393 \\
\hline $\mathrm{C}$ & 5.96528 & -1.52107 & 3.03203 \\
\hline $\mathrm{C}$ & 5.65538 & -1.88674 & 4.36550 \\
\hline $\mathrm{H}$ & 6.44384 & -2.16110 & 5.05501 \\
\hline $\mathrm{C}$ & 4.34975 & -1.91043 & 4.78348 \\
\hline $\mathrm{H}$ & 4.11043 & -2.20904 & 5.79996 \\
\hline $\mathrm{C}$ & 3.29619 & -1.55991 & 3.90893 \\
\hline $\mathrm{C}$ & 1.93747 & -1.65437 & 4.31268 \\
\hline $\mathrm{H}$ & 1.68162 & -1.99914 & 5.31073 \\
\hline $\mathrm{C}$ & 0.94836 & -1.34677 & 3.42165 \\
\hline $\mathrm{C}$ & 1.23490 & -0.88928 & 2.11301 \\
\hline $\mathrm{H}$ & 0.43919 & -0.62122 & 1.42319 \\
\hline $\mathrm{C}$ & 2.53817 & -0.78469 & 1.71462 \\
\hline $\mathrm{H}$ & 2.75911 & -0.42743 & 0.71538 \\
\hline $\mathrm{C}$ & 3.61014 & -1.15539 & 2.57929 \\
\hline $\mathrm{C}$ & -2.89222 & -0.28940 & 4.14893 \\
\hline $\mathrm{H}$ & -2.79492 & -0.49658 & 5.21774 \\
\hline $\mathrm{H}$ & -3.24472 & 0.73969 & 4.03293 \\
\hline $\mathrm{C}$ & -3.88966 & -1.27183 & 3.51839 \\
\hline $\mathrm{H}$ & -4.86265 & -1.18335 & 4.01318 \\
\hline $\mathrm{H}$ & -3.54606 & -2.30128 & 3.65846 \\
\hline $\mathrm{C}$ & 6.33256 & -4.15087 & -0.34908 \\
\hline $\mathrm{H}$ & 7.35394 & -3.93861 & -0.68533 \\
\hline $\mathrm{H}$ & 5.69833 & -4.35001 & -1.22169 \\
\hline $\mathrm{C}$ & 8.27822 & -1.92750 & 3.39853 \\
\hline $\mathrm{H}$ & 8.13128 & -2.96206 & 3.73020 \\
\hline $\mathrm{H}$ & 8.37387 & -1.27579 & 4.27471 \\
\hline $\mathrm{O}$ & -0.11690 & -0.17792 & -0.68765 \\
\hline $\mathrm{O}$ & -1.89043 & -0.02861 & 0.66568 \\
\hline $\mathrm{N}$ & -1.23789 & -1.67821 & -2.48637 \\
\hline $\mathrm{H}$ & -1.78947 & -2.18723 & -3.19064 \\
\hline $\mathrm{H}$ & -0.49209 & -2.30114 & -2.14052 \\
\hline $\mathrm{H}$ & -0.77570 & -0.85999 & -2.92344 \\
\hline $\mathrm{C}$ & -2.14030 & -1.21764 & -1.38917 \\
\hline $\mathrm{C}$ & -1.30652 & -0.40443 & -0.37902 \\
\hline $\mathrm{O}$ & -0.37627 & 0.78407 & -3.72515 \\
\hline $\mathrm{O}$ & -2.74199 & -0.45863 & -4.67430 \\
\hline $\mathrm{O}$ & -3.41337 & -3.03648 & -3.85366 \\
\hline $\mathrm{O}$ & -1.32943 & -4.65859 & -2.95655 \\
\hline $\mathrm{O}$ & 1.00891 & -3.52228 & -1.89310 \\
\hline $\mathrm{O}$ & 1.71169 & -0.93964 & -2.94463 \\
\hline $\mathrm{C}$ & -1.20550 & 1.36738 & -4.71333 \\
\hline $\mathrm{H}$ & -0.86779 & 1.04983 & -5.71200 \\
\hline $\mathrm{H}$ & -1.14482 & 2.46254 & -4.64444 \\
\hline $\mathrm{C}$ & -2.63792 & 0.94595 & -4.50985 \\
\hline $\mathrm{H}$ & -2.98186 & 1.24565 & -3.51375 \\
\hline $\mathrm{H}$ & -3.25589 & 1.45809 & -5.26437 \\
\hline $\mathrm{C}$ & -4.08049 & -0.88628 & -4.59953 \\
\hline $\mathrm{H}$ & -4.69772 & -0.36443 & -5.34793 \\
\hline $\mathrm{H}$ & -4.50499 & -0.67051 & -3.60595 \\
\hline $\mathrm{C}$ & -4.12619 & -2.36877 & -4.87215 \\
\hline $\mathrm{H}$ & -5.17288 & -2.70791 & -4.88755 \\
\hline $\mathrm{H}$ & -3.67585 & -2.58040 & -5.85334 \\
\hline $\mathrm{C}$ & -3.44378 & -4.43996 & -4.00233 \\
\hline $\mathrm{H}$ & -2.99649 & -4.72298 & -4.96712 \\
\hline
\end{tabular}

$\begin{array}{lrrr}\mathrm{H} & -4.48373 & -4.79915 & -3.98107 \\ \mathrm{C} & -2.67368 & -5.08350 & -2.87563 \\ \mathrm{H} & -3.10827 & -4.81725 & -1.90341 \\ \mathrm{H} & -2.73620 & -6.17709 & -2.99644 \\ \mathrm{C} & -0.50772 & -5.34764 & -2.04082 \\ \mathrm{H} & -0.55908 & -6.43325 & -2.22223 \\ \mathrm{H} & -0.83454 & -5.15539 & -1.00934 \\ \mathrm{C} & 0.91458 & -4.88703 & -2.23259 \\ \mathrm{H} & 1.57967 & -5.48551 & -1.59127 \\ \mathrm{H} & 1.21565 & -5.03651 & -3.28034 \\ \mathrm{C} & 2.33339 & -3.03297 & -1.99809 \\ \mathrm{H} & 2.75272 & -3.28872 & -2.98283 \\ \mathrm{H} & 2.96197 & -3.48786 & -1.21584 \\ \mathrm{C} & 2.31836 & -1.53956 & -1.81782 \\ \mathrm{H} & 1.74860 & -1.29058 & -0.91600 \\ \mathrm{H} & 3.35457 & -1.18491 & -1.70187 \\ \mathrm{C} & 1.84554 & 0.46520 & -2.89100 \\ \mathrm{H} & 2.89615 & 0.75569 & -3.06760 \\ \mathrm{H} & 1.53999 & 0.83661 & -1.90744 \\ \mathrm{C} & 0.98425 & 1.08921 & -3.95967 \\ \mathrm{H} & 1.12540 & 2.18086 & -3.94784 \\ \mathrm{H} & 1.28374 & 0.71071 & -4.94927 \\ \mathrm{H} & 6.33894 & -5.02937 & 0.29488 \\ \mathrm{H} & 9.18971 & -1.86437 & 2.80509 \\ \mathrm{H} & -1.81676 & 7.34205 & 1.01246 \\ \mathrm{H} & -6.68618 & 3.08209 & 4.95848 \\ \mathrm{C} & -2.85413 & -2.36835 & -0.72505 \\ \mathrm{C} & -2.15398 & -3.17897 & 0.16777 \\ \mathrm{C} & -4.21890 & -2.58214 & -0.92066 \\ \mathrm{C} & -2.80990 & -4.19336 & 0.86181 \\ \mathrm{H} & -1.10101 & -2.98847 & 0.36919 \\ \mathrm{C} & -4.87681 & -3.59440 & -0.22964 \\ \mathrm{H} & -4.77621 & -1.92190 & -1.57589 \\ \mathrm{C} & -4.17173 & -4.40228 & 0.66103 \\ \mathrm{H} & -2.25906 & -4.77809 & 1.59066 \\ \mathrm{H} & -5.94529 & -3.73013 & -0.36207 \\ \mathrm{H} & -4.69016 & -5.17674 & 1.21759 \\ \mathrm{H} & -2.86169 & -0.52549 & -1.83637 \\ & & & \\ & & \end{array}$


$(S)$-2• L-phenylglycine

(binaphthyl gap occupied by 18 -crown-6 ether, alternative, gauche conformations for both ethylenediamine) $\Delta \mathrm{G}: 14.8 \mathrm{kcal} / \mathrm{mol}$

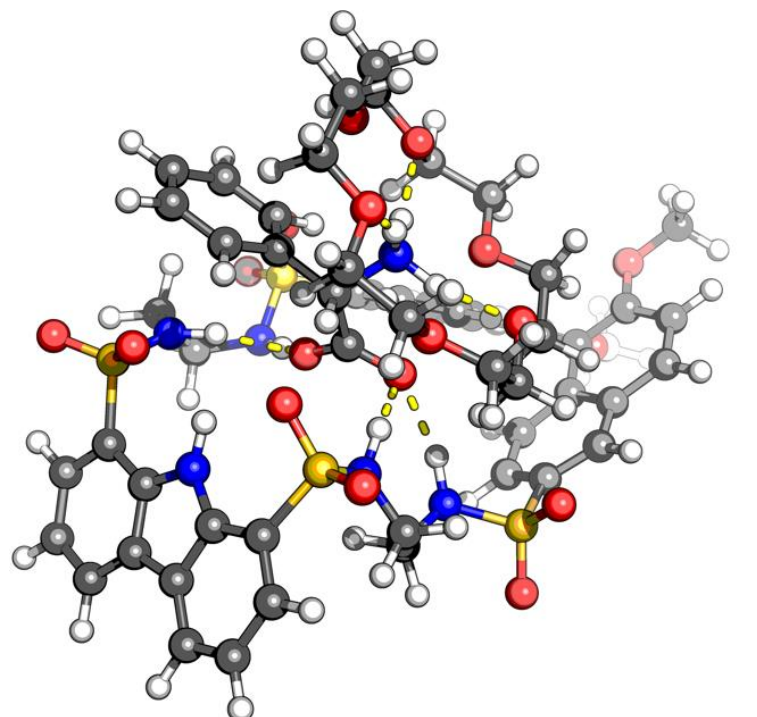

2.73719

4.47575

0.63150

S $\quad-1.29632$

$-1.16255$

4.49190

$-3.84730$

$-2.72035$

0.50110

0.07601

2.74555

2.13184

3.21529

2.41524

$-2.82207$

$-2.03241$

$-2.90633$

$-2.19667$

3.89788

1.39050

5.02328

5.39570

$-4.18881$

$-4.93465$

$-2.03676$

$-4.00159$

0.03179

0.15986

4.13390

4.96515

4.30064

3.24284

3.38872

1.98907

0.69015

0.21357
0.89146

$-1.13830$

$-5.68215$

C $\quad 5.22168$

$-2.02600$

$-3.09379$

$-1.56903$

$-0.19947$

1.81146

2.89826

3.96069

4.50722

4.62003

3.59951

4.44897

2.75964

3.59904

3.83238

4.60764

2.98518

3.12001

3.96687

2.18328

2.30229

1.04156

0.88997

1.89509

1.80161

1.03151

2.62561

2.51699

$-0.36114$

$-0.70237$

$-1.88060$

$-2.14323$

$-2.68126$

$-3.57167$

$-2.36391$

$-3.16481$

$-4.04474$

$-2.81650$

$-1.69428$

$-1.44004$

$-0.91751$

$-0.06241$

$-1.20531$

$-3.45316$

$-4.27549$

$-2.70388$

$-3.97404$

$-4.58901$

$-4.60796$

0.15210

1.02407

0.22096

$-0.16977$

$-1.11605$
$-5.20284$

$-4.21290$

$-4.40277$

$-2.94835$

$-2.67707$

$-1.70782$

$-0.83057$

$-0.67767$

$-1.05691$

0.02281

$-1.86126$

$-2.54393$

$-2.40247$

$-1.18067$

$-0.17290$

0.56114

$-0.02959$

1.05780

1.72955

1.28777

2.13282

0.45167

$-0.64665$

$-0.92975$

$-2.05793$

$-2.79936$

$-2.18071$

$-2.99841$

$-1.44658$

$-2.18616$

$-2.97402$

$-3.54524$

$-3.03630$

$-3.65797$

$-2.31143$

$-2.40868$

$-3.04535$

$-1.70225$

$-0.83866$

$-0.27500$

$-0.73067$

$-0.06488$

$-1.48270$

$-3.14347$

$-3.75567$

$-3.80837$

$-2.17369$

$-2.70896$

$-1.41190$

1.78561

1.67668

2.73795

$-2.82253$

$-2.46550$ 


\begin{tabular}{|c|c|c|c|}
\hline $\mathrm{H}$ & -9.19949 & -0.23234 & -3.90361 \\
\hline $\mathrm{O}$ & 0.24509 & 0.97058 & 0.39827 \\
\hline $\mathrm{O}$ & 0.96927 & -0.88243 & -0.65643 \\
\hline $\mathrm{N}$ & 0.60886 & -0.28618 & 2.79347 \\
\hline $\mathrm{H}$ & 1.15639 & -0.22452 & 3.66506 \\
\hline $\mathrm{H}$ & -0.09310 & -1.03181 & 2.91445 \\
\hline $\mathrm{H}$ & 0.11961 & 0.61580 & 2.64400 \\
\hline $\mathrm{C}$ & 1.54358 & -0.55347 & 1.65688 \\
\hline $\mathrm{C}$ & 0.83856 & -0.13795 & 0.33272 \\
\hline $\mathrm{O}$ & 1.93061 & 2.15496 & 3.24436 \\
\hline $\mathrm{O}$ & 2.65401 & -0.02385 & 4.83953 \\
\hline $\mathrm{O}$ & 1.17726 & -2.42249 & 4.80255 \\
\hline $\mathrm{O}$ & -1.33367 & -2.39635 & 3.59061 \\
\hline $\mathrm{O}$ & -2.32724 & -0.24765 & 2.19778 \\
\hline $\mathrm{O}$ & -0.87394 & 2.20136 & 2.85784 \\
\hline $\mathrm{C}$ & 3.04975 & 2.20799 & 4.11129 \\
\hline $\mathrm{H}$ & 2.72793 & 2.57353 & 5.09832 \\
\hline $\mathrm{H}$ & 3.80959 & 2.89027 & 3.70685 \\
\hline $\mathrm{C}$ & 3.63971 & 0.82962 & 4.27493 \\
\hline $\mathrm{H}$ & 3.98988 & 0.44183 & 3.31178 \\
\hline $\mathrm{H}$ & 4.50297 & 0.90048 & 4.95337 \\
\hline $\mathrm{C}$ & 3.18853 & -1.25399 & 5.28631 \\
\hline $\mathrm{H}$ & 3.93460 & -1.07405 & 6.07513 \\
\hline $\mathrm{H}$ & 3.67193 & -1.79148 & 4.46058 \\
\hline $\mathrm{C}$ & 2.06473 & -2.08966 & 5.84529 \\
\hline $\mathrm{H}$ & 2.48497 & -3.00130 & 6.29817 \\
\hline $\mathrm{H}$ & 1.53876 & -1.52627 & 6.63200 \\
\hline $\mathrm{C}$ & 0.11738 & -3.23010 & 5.25924 \\
\hline $\mathrm{H}$ & -0.47043 & -2.69263 & 6.01993 \\
\hline $\mathrm{H}$ & 0.50624 & -4.15441 & 5.71487 \\
\hline $\mathrm{C}$ & -0.77420 & -3.59173 & 4.09660 \\
\hline $\mathrm{H}$ & -0.20100 & -4.11606 & 3.32316 \\
\hline $\mathrm{H}$ & -1.57395 & -4.25646 & 4.45651 \\
\hline $\mathrm{C}$ & -2.36426 & -2.59071 & 2.63744 \\
\hline $\mathrm{H}$ & -3.02422 & -3.41176 & 2.95312 \\
\hline $\mathrm{H}$ & -1.95190 & -2.85203 & 1.65205 \\
\hline $\mathrm{C}$ & -3.16613 & -1.31242 & 2.59667 \\
\hline $\mathrm{H}$ & -4.01586 & -1.41550 & 1.90503 \\
\hline $\mathrm{H}$ & -3.55796 & -1.11865 & 3.60657 \\
\hline $\mathrm{C}$ & -2.92049 & 1.00228 & 2.49486 \\
\hline $\mathrm{H}$ & -3.10190 & 1.08144 & 3.57779 \\
\hline $\mathrm{H}$ & -3.89134 & 1.09398 & 1.97801 \\
\hline $\mathrm{C}$ & -2.02984 & 2.13079 & 2.04303 \\
\hline $\mathrm{H}$ & -1.74495 & 1.97824 & 0.99391 \\
\hline $\mathrm{H}$ & -2.59018 & 3.07415 & 2.12181 \\
\hline $\mathrm{C}$ & -0.03912 & 3.27059 & 2.43902 \\
\hline $\mathrm{H}$ & -0.58558 & 4.22158 & 2.49537 \\
\hline $\mathrm{H}$ & 0.23959 & 3.12307 & 1.39100 \\
\hline C & 1.18051 & 3.35262 & 3.31931 \\
\hline $\mathrm{H}$ & 1.79608 & 4.20336 & 2.98858 \\
\hline $\mathrm{H}$ & 0.87359 & 3.52795 & 4.36184 \\
\hline $\mathrm{H}$ & -9.18708 & -0.75427 & 1.78137 \\
\hline $\mathrm{H}$ & -10.07069 & 0.63841 & -2.61762 \\
\hline $\mathrm{H}$ & 6.38767 & 5.27242 & -2.79962 \\
\hline $\mathrm{H}$ & 5.92342 & -1.52199 & -6.18322 \\
\hline
\end{tabular}

$\begin{array}{lrrr}\mathrm{H} & 2.36962 & 0.15415 & 1.78341 \\ \mathrm{C} & 2.05271 & -1.96421 & 1.69270 \\ \mathrm{C} & 3.39313 & -2.23386 & 1.94383 \\ \mathrm{C} & 1.18447 & -3.02082 & 1.41382 \\ \mathrm{C} & 3.85919 & -3.54849 & 1.95120 \\ \mathrm{H} & 4.09406 & -1.41271 & 2.07213 \\ \mathrm{C} & 1.64393 & -4.33129 & 1.40981 \\ \mathrm{H} & 0.15167 & -2.81664 & 1.14731 \\ \mathrm{C} & 2.98571 & -4.59699 & 1.69030 \\ \mathrm{H} & 4.91451 & -3.74107 & 2.11279 \\ \mathrm{H} & 0.95605 & -5.13058 & 1.15051 \\ \mathrm{H} & 3.35342 & -5.61810 & 1.67152\end{array}$

(S)-2• L-phenylglycine (binaphthyl gap occupied by 18 -crown- 6 ether, alternative) $\Delta \mathrm{G}: 17.8 \mathrm{kcal} / \mathrm{mol}$

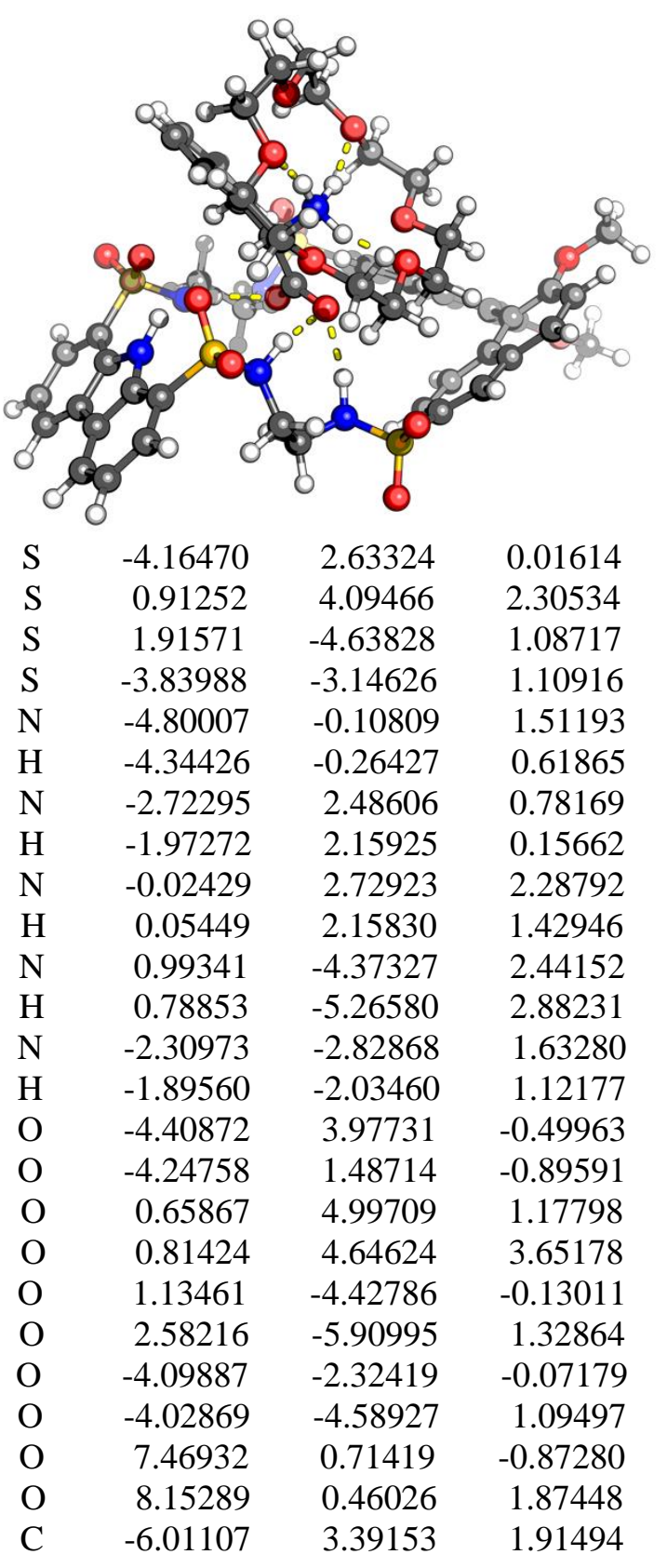




\begin{tabular}{|c|c|c|c|c|c|c|c|}
\hline $\mathrm{H}$ & -5.92735 & 4.37704 & 1.46756 & $\mathrm{H}$ & -1.82325 & -4.70107 & 2.43117 \\
\hline $\mathrm{C}$ & -6.81553 & 3.16774 & 3.03936 & $\mathrm{H}$ & -1.14823 & -4.42284 & 0.81473 \\
\hline $\mathrm{C}$ & -6.89649 & 1.90382 & 3.61261 & $\mathrm{C}$ & 8.29740 & 1.17288 & -1.91897 \\
\hline $\mathrm{H}$ & -7.51121 & 1.74076 & 4.49294 & $\mathrm{H}$ & 8.86780 & 2.05979 & -1.61972 \\
\hline $\mathrm{C}$ & -6.18805 & 0.84336 & 3.04693 & $\mathrm{H}$ & 7.71855 & 1.40226 & -2.82150 \\
\hline $\mathrm{C}$ & -6.06035 & -0.56770 & 3.35464 & $\mathrm{C}$ & 9.43614 & 0.21334 & 2.40724 \\
\hline $\mathrm{C}$ & -6.59486 & -1.39855 & 4.34110 & $\mathrm{H}$ & 9.96691 & -0.55632 & 1.83490 \\
\hline $\mathrm{H}$ & -7.25332 & -0.99098 & 5.10225 & $\mathrm{H}$ & 9.38480 & -0.08742 & 3.46007 \\
\hline $\mathrm{C}$ & -6.28752 & -2.75249 & 4.32999 & $\mathrm{O}$ & -0.32927 & 1.24292 & -0.19075 \\
\hline $\mathrm{C}$ & -5.44772 & -3.28781 & 3.34379 & $\mathrm{O}$ & -0.60671 & -0.83301 & 0.60453 \\
\hline $\mathrm{H}$ & -5.22415 & -4.34936 & 3.31469 & $\mathrm{~N}$ & -0.70681 & 0.37303 & -2.72286 \\
\hline $\mathrm{C}$ & -4.89954 & -2.47392 & 2.36524 & $\mathrm{H}$ & -1.32911 & 0.55329 & -3.52545 \\
\hline $\mathrm{C}$ & -5.20554 & -1.10918 & 2.36715 & $\mathrm{H}$ & 0.06297 & -0.22818 & -3.05237 \\
\hline $\mathrm{C}$ & -5.38978 & 1.06691 & 1.90011 & $\mathrm{H}$ & -0.30844 & 1.27699 & -2.40712 \\
\hline $\mathrm{C}$ & -5.29002 & 2.34914 & 1.34941 & $\mathrm{C}$ & -1.46122 & -0.26619 & -1.59570 \\
\hline $\mathrm{C}$ & -2.36083 & 3.49574 & 1.78148 & $\mathrm{C}$ & -0.70929 & 0.04132 & -0.26906 \\
\hline $\mathrm{H}$ & -3.27683 & 3.78275 & 2.30833 & $\mathrm{O}$ & -2.04611 & 2.88917 & -2.60840 \\
\hline $\mathrm{H}$ & -1.93404 & 4.39611 & 1.32264 & $\mathrm{O}$ & -2.72118 & 1.19463 & -4.72675 \\
\hline $\mathrm{C}$ & -1.38812 & 2.88861 & 2.79073 & $\mathrm{O}$ & -1.33738 & -1.09489 & -5.30871 \\
\hline $\mathrm{H}$ & -1.33571 & 3.51562 & 3.68444 & $\mathrm{O}$ & 1.13110 & -1.52124 & -4.04001 \\
\hline $\mathrm{H}$ & -1.74757 & 1.89741 & 3.08153 & $\mathrm{O}$ & 2.15652 & 0.23447 & -2.16321 \\
\hline $\mathrm{C}$ & 2.48950 & 3.34097 & 2.00941 & $\mathrm{O}$ & 0.76196 & 2.82176 & -2.31343 \\
\hline $\mathrm{C}$ & 3.29671 & 3.86436 & 1.03942 & $\mathrm{C}$ & -3.18137 & 3.12804 & -3.42123 \\
\hline $\mathrm{H}$ & 3.00228 & 4.77424 & 0.52347 & $\mathrm{H}$ & -2.88812 & 3.74752 & -4.28234 \\
\hline $\mathrm{C}$ & 4.45527 & 3.15185 & 0.63326 & $\mathrm{H}$ & -3.95528 & 3.65579 & -2.84896 \\
\hline $\mathrm{C}$ & 5.26443 & 3.60924 & -0.43207 & $\mathrm{C}$ & -3.72959 & 1.82482 & -3.94626 \\
\hline $\mathrm{H}$ & 5.05395 & 4.57925 & -0.87451 & $\mathrm{H}$ & -4.04894 & 1.17344 & -3.12498 \\
\hline $\mathrm{C}$ & 6.28520 & 2.83680 & -0.92510 & $\mathrm{H}$ & -4.60382 & 2.05032 & -4.57426 \\
\hline $\mathrm{H}$ & 6.88416 & 3.20314 & -1.74950 & $\mathrm{C}$ & -3.23289 & 0.26157 & -5.65101 \\
\hline $\mathrm{C}$ & 6.52780 & 1.55224 & -0.37730 & $\mathrm{H}$ & -3.84457 & 0.77234 & -6.41000 \\
\hline $\mathrm{C}$ & 5.77989 & 1.07985 & 0.69465 & $\mathrm{H}$ & -3.86232 & -0.48622 & -5.14780 \\
\hline $\mathrm{C}$ & 4.74798 & 1.89475 & 1.23504 & $\mathrm{C}$ & -2.06536 & -0.43036 & -6.31163 \\
\hline $\mathrm{C}$ & 3.95250 & 1.46793 & 2.34181 & $\mathrm{H}$ & -2.44483 & -1.14332 & -7.06034 \\
\hline $\mathrm{H}$ & 4.21669 & 0.55324 & 2.85935 & $\mathrm{H}$ & -1.43017 & 0.30627 & -6.82731 \\
\hline $\mathrm{C}$ & 2.84029 & 2.16482 & 2.71703 & $\mathrm{C}$ & -0.35287 & -1.95896 & -5.82431 \\
\hline $\mathrm{H}$ & 2.19464 & 1.81204 & 3.51327 & $\mathrm{H}$ & 0.34141 & -1.40607 & -6.47598 \\
\hline C & 6.04069 & -0.28248 & 1.22926 & $\mathrm{H}$ & -0.81949 & -2.76236 & -6.41557 \\
\hline C & 7.26917 & -0.56335 & 1.81152 & $\mathrm{C}$ & 0.40874 & -2.56296 & -4.67057 \\
\hline C & 7.55789 & -1.85304 & 2.32343 & $\mathrm{H}$ & -0.28424 & -3.04442 & -3.96993 \\
\hline $\mathrm{H}$ & 8.52145 & -2.06103 & 2.77132 & $\mathrm{H}$ & 1.10681 & -3.32068 & -5.05649 \\
\hline C & 6.60884 & -2.83856 & 2.26566 & $\mathrm{C}$ & 2.08530 & -1.96080 & -3.09069 \\
\hline $\mathrm{H}$ & 6.82207 & -3.82495 & 2.66712 & $\mathrm{H}$ & 2.71321 & -2.75561 & -3.51982 \\
\hline C & 5.33649 & -2.59313 & 1.69897 & $\mathrm{H}$ & 1.59453 & -2.36616 & -2.19444 \\
\hline $\mathrm{C}$ & 4.34628 & -3.60565 & 1.66478 & $\mathrm{C}$ & 2.95164 & -0.76650 & -2.76946 \\
\hline $\mathrm{H}$ & 4.56039 & -4.59482 & 2.05957 & $\mathrm{H}$ & 3.78028 & -1.05727 & -2.10774 \\
\hline $\mathrm{C}$ & 3.11884 & -3.33629 & 1.12472 & $\mathrm{H}$ & 3.37312 & -0.38743 & -3.71230 \\
\hline $\mathrm{C}$ & 2.81245 & -2.07129 & 0.56513 & $\mathrm{C}$ & 2.77971 & 1.50400 & -2.24327 \\
\hline $\mathrm{H}$ & 1.83246 & -1.87323 & 0.13736 & $\mathrm{H}$ & 2.94591 & 1.77011 & -3.29854 \\
\hline $\mathrm{C}$ & 3.76494 & -1.08800 & 0.57665 & $\mathrm{H}$ & 3.76054 & 1.47452 & -1.73823 \\
\hline $\mathrm{H}$ & 3.52318 & -0.12578 & 0.13672 & $\mathrm{C}$ & 1.94028 & 2.56292 & -1.57339 \\
\hline $\mathrm{C}$ & 5.05059 & -1.30462 & 1.15918 & $\mathrm{H}$ & 1.68619 & 2.24629 & -0.55445 \\
\hline $\mathrm{C}$ & -0.09143 & -3.39328 & 2.39002 & $\mathrm{H}$ & 2.54087 & 3.48370 & -1.51849 \\
\hline $\mathrm{H}$ & -0.27859 & -3.03988 & 3.40769 & $\mathrm{C}$ & -0.03515 & 3.79664 & -1.65595 \\
\hline $\mathrm{H}$ & 0.25045 & -2.52565 & 1.81671 & $\mathrm{H}$ & 0.52957 & 4.73398 & -1.54470 \\
\hline $\mathrm{C}$ & -1.37660 & -3.94778 & 1.77511 & $\mathrm{H}$ & -0.29468 & 3.45134 & -0.65112 \\
\hline
\end{tabular}




$\begin{array}{lrrr}\mathrm{C} & -1.27498 & 4.06890 & -2.46791 \\ \mathrm{H} & -1.86335 & 4.84917 & -1.96188 \\ \mathrm{H} & -0.98993 & 4.43880 & -3.46478 \\ \mathrm{H} & 8.98654 & 0.35701 & -2.13427 \\ \mathrm{H} & 9.97653 & 1.15632 & 2.33197 \\ \mathrm{H} & -7.36955 & 3.99394 & 3.46998 \\ \mathrm{H} & -6.70554 & -3.40901 & 5.08467 \\ \mathrm{H} & -2.39529 & 0.30616 & -1.51938 \\ \mathrm{C} & -1.79279 & -1.69621 & -1.94145 \\ \mathrm{C} & -2.88791 & -1.92105 & -2.77564 \\ \mathrm{C} & -1.06024 & -2.79035 & -1.48273 \\ \mathrm{C} & -3.24708 & -3.20612 & -3.15823 \\ \mathrm{H} & -3.48059 & -1.06881 & -3.09928 \\ \mathrm{C} & -1.42241 & -4.08554 & -1.85427 \\ \mathrm{H} & -0.22738 & -2.64953 & -0.80461 \\ \mathrm{C} & -2.51427 & -4.29541 & -2.69213 \\ \mathrm{H} & -4.11215 & -3.36095 & -3.79575 \\ \mathrm{H} & -0.83467 & -4.91886 & -1.48219 \\ \mathrm{H} & -2.80163 & -5.30479 & -2.96904\end{array}$

(S)-2• L-phenylglycine

(binaphthyl gap occupied by phenyl group) $\Delta \mathrm{G}: 10.3 \mathrm{kcal} / \mathrm{mol}$

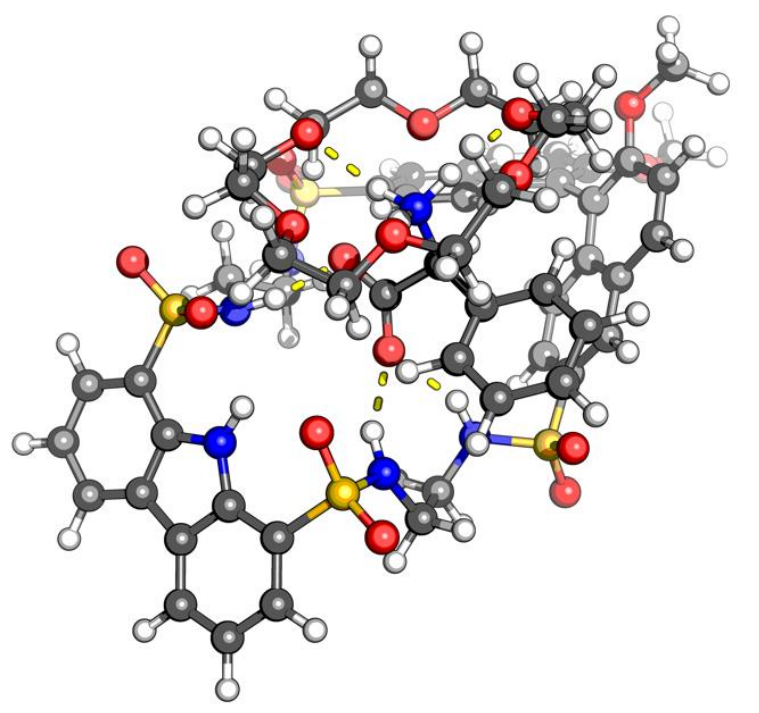

$\begin{array}{lrrr}\mathrm{S} & 2.31701 & 3.01052 & 1.70440 \\ \mathrm{~S} & -2.91971 & 5.76963 & 0.38554 \\ \mathrm{~S} & 0.97885 & -1.76497 & -3.37591 \\ \mathrm{~S} & 5.57862 & -1.41515 & -0.63997 \\ \mathrm{~N} & 4.58108 & 1.59775 & -0.15023 \\ \mathrm{H} & 4.14324 & 0.94063 & 0.49024 \\ \mathrm{~N} & 0.99207 & 2.57158 & 0.84186 \\ \mathrm{H} & 1.10495 & 1.63222 & 0.42873 \\ \mathrm{~N} & -1.34638 & 5.37315 & 0.02327 \\ \mathrm{H} & -0.84120 & 6.21801 & -0.23079 \\ \mathrm{~N} & 1.97708 & -0.46886 & -3.09491 \\ \mathrm{H} & 1.95110 & -0.22715 & -2.08988 \\ \mathrm{~N} & 4.14527 & -1.53601 & -1.40301 \\ \mathrm{H} & 3.35376 & -1.72635 & -0.75843 \\ \mathrm{O} & 1.92160 & 4.05812 & 2.63742 \\ \mathrm{O} & 2.92617 & 1.77084 & 2.17593 \\ \mathrm{O} & -3.12921 & 5.95523 & 1.81516 \\ \mathrm{O} & -3.27121 & 6.82252 & -0.55472 \\ \mathrm{O} & 1.09820 & -2.75044 & -2.29364 \\ \mathrm{O} & 1.18992 & -2.20970 & -4.74896 \\ \mathrm{O} & 5.26004 & -1.19698 & 0.76797 \\ \mathrm{O} & 6.49835 & -2.47353 & -1.03775 \\ \mathrm{O} & -6.00534 & -1.66942 & -0.25072 \\ \mathrm{O} & -6.97504 & -0.60013 & -2.68737 \\ \mathrm{C} & 3.46674 & 5.12150 & 0.38310 \\ \mathrm{H} & 2.79140 & 5.72093 & 0.98577 \\ \mathrm{C} & 4.34150 & 5.72364 & -0.52840 \\ \mathrm{C} & 5.23984 & 4.95163 & -1.25294 \\ \mathrm{H} & 5.92927 & 5.41771 & -1.95061 \\ \mathrm{C} & 5.26219 & 3.56982 & -1.06663 \\ \mathrm{C} & 6.07795 & 2.50587 & -1.60956 \\ \mathrm{C} & 7.13597 & 2.46688 & -2.52022 \\ \mathrm{H} & 7.48689 & 3.38156 & -2.98881 \\ \mathrm{C} & 7.73738 & 1.25127 & -2.81310 \\ & & & \end{array}$




\begin{tabular}{|c|c|c|c|c|c|c|c|}
\hline $\mathrm{C}$ & 7.28308 & 0.06909 & -2.21143 & $\mathrm{O}$ & 2.18995 & -1.93906 & 0.52355 \\
\hline $\mathrm{H}$ & 7.74613 & -0.88810 & -2.42930 & $\mathrm{~N}$ & 0.08223 & -2.62955 & 1.84833 \\
\hline $\mathrm{C}$ & 6.22703 & 0.09103 & -1.31323 & $\mathrm{H}$ & -0.82425 & -2.84473 & 2.28230 \\
\hline $\mathrm{C}$ & 5.62227 & 1.31395 & -1.00223 & $\mathrm{H}$ & 0.80951 & -2.61602 & 2.58129 \\
\hline $\mathrm{C}$ & 4.36287 & 2.95536 & -0.15974 & $\mathrm{H}$ & 0.34405 & -3.38031 & 1.18054 \\
\hline $\mathrm{C}$ & 3.46525 & 3.74431 & 0.57064 & $\mathrm{C}$ & -0.01915 & -1.33242 & 1.12637 \\
\hline $\mathrm{C}$ & 0.27747 & 3.56698 & 0.05334 & $\mathrm{C}$ & 1.32465 & -1.06278 & 0.40604 \\
\hline $\mathrm{H}$ & -0.33594 & 3.01947 & -0.66893 & $\mathrm{O}$ & 0.51848 & -4.54139 & -0.19534 \\
\hline $\mathrm{H}$ & 0.96526 & 4.20183 & -0.52692 & $\mathrm{O}$ & -2.11903 & -3.77237 & 0.30646 \\
\hline $\mathrm{C}$ & -0.64275 & 4.43726 & 0.90880 & $\mathrm{O}$ & -2.72327 & -2.33820 & 2.59780 \\
\hline $\mathrm{H}$ & -1.38027 & 3.79053 & 1.39360 & $\mathrm{O}$ & -0.84651 & -2.47034 & 4.63964 \\
\hline $\mathrm{H}$ & -0.09032 & 4.94903 & 1.70120 & $\mathrm{O}$ & 1.91720 & -2.91318 & 4.08745 \\
\hline $\mathrm{C}$ & -3.70756 & 4.24025 & -0.05850 & $\mathrm{O}$ & 2.42840 & -4.55235 & 1.81188 \\
\hline $\mathrm{C}$ & -4.37698 & 3.53540 & 0.90090 & $\mathrm{C}$ & -0.53586 & -4.92792 & -1.04494 \\
\hline $\mathrm{H}$ & -4.47734 & 3.94837 & 1.90123 & $\mathrm{H}$ & -0.94902 & -5.89560 & -0.71982 \\
\hline $\mathrm{C}$ & -4.89007 & 2.24734 & 0.59496 & $\mathrm{H}$ & -0.16752 & -5.01766 & -2.07596 \\
\hline $\mathrm{C}$ & -5.55484 & 1.47221 & 1.57440 & $\mathrm{C}$ & -1.61084 & -3.87217 & -1.01073 \\
\hline $\mathrm{H}$ & -5.72399 & 1.90067 & 2.55830 & $\mathrm{H}$ & -1.19179 & -2.91176 & -1.33786 \\
\hline $\mathrm{C}$ & -5.96899 & 0.19684 & 1.29334 & $\mathrm{H}$ & -2.41466 & -4.15355 & -1.70972 \\
\hline $\mathrm{H}$ & -6.47754 & -0.39053 & 2.05018 & $\mathrm{C}$ & -3.26341 & -2.95477 & 0.36948 \\
\hline $\mathrm{C}$ & -5.69857 & -0.37064 & 0.02378 & $\mathrm{H}$ & -4.06671 & -3.34643 & -0.27163 \\
\hline $\mathrm{C}$ & -5.05454 & 0.35121 & -0.96894 & $\mathrm{H}$ & -3.04149 & -1.93225 & 0.01919 \\
\hline $\mathrm{C}$ & -4.67872 & 1.69967 & -0.70232 & $\mathrm{C}$ & -3.73549 & -2.91601 & 1.80048 \\
\hline $\mathrm{C}$ & -4.05504 & 2.51578 & -1.69367 & $\mathrm{H}$ & -4.65473 & -2.31376 & 1.85919 \\
\hline $\mathrm{H}$ & -3.94280 & 2.12449 & -2.69895 & $\mathrm{H}$ & -3.95668 & -3.93528 & 2.15163 \\
\hline $\mathrm{C}$ & -3.57190 & 3.75574 & -1.38277 & $\mathrm{C}$ & -3.10404 & -2.22351 & 3.95119 \\
\hline $\mathrm{H}$ & -3.06851 & 4.36782 & -2.12387 & $\mathrm{H}$ & -3.35591 & -3.21673 & 4.35305 \\
\hline $\mathrm{C}$ & -4.70158 & -0.32592 & -2.24695 & $\mathrm{H}$ & -3.99124 & -1.57658 & 4.04028 \\
\hline $\mathrm{C}$ & -5.69589 & -0.82659 & -3.07491 & $\mathrm{C}$ & -1.97140 & -1.62379 & 4.75026 \\
\hline $\mathrm{C}$ & -5.36462 & -1.53267 & -4.25847 & $\mathrm{H}$ & -1.73208 & -0.61338 & 4.39443 \\
\hline $\mathrm{H}$ & -6.14530 & -1.91248 & -4.90563 & $\mathrm{H}$ & -2.29437 & -1.55259 & 5.80144 \\
\hline $\mathrm{C}$ & -4.05060 & -1.75071 & -4.58781 & $\mathrm{C}$ & 0.18916 & -2.08232 & 5.51791 \\
\hline $\mathrm{H}$ & -3.80299 & -2.30519 & -5.48823 & $\mathrm{H}$ & -0.16665 & -2.11688 & 6.55996 \\
\hline $\mathrm{C}$ & -3.00250 & -1.27153 & -3.76893 & $\mathrm{H}$ & 0.51354 & -1.05552 & 5.30051 \\
\hline $\mathrm{C}$ & -1.63812 & -1.55447 & -4.06071 & $\mathrm{C}$ & 1.34561 & -3.03861 & 5.37137 \\
\hline $\mathrm{H}$ & -1.37658 & -2.15735 & -4.92629 & $\mathrm{H}$ & 2.09627 & -2.81016 & 6.14317 \\
\hline $\mathrm{C}$ & -0.65882 & -1.09289 & -3.22460 & $\mathrm{H}$ & 0.99417 & -4.06947 & 5.52809 \\
\hline $\mathrm{C}$ & -0.96673 & -0.30270 & -2.09222 & $\mathrm{C}$ & 3.06112 & -3.74351 & 3.93961 \\
\hline $\mathrm{H}$ & -0.17456 & 0.06220 & -1.44496 & $\mathrm{H}$ & 2.83105 & -4.74949 & 4.31968 \\
\hline $\mathrm{C}$ & -2.27123 & -0.04429 & -1.78669 & $\mathrm{H}$ & 3.89397 & -3.32776 & 4.52407 \\
\hline $\mathrm{H}$ & -2.49241 & 0.54299 & -0.90446 & $\mathrm{C}$ & 3.44912 & -3.84124 & 2.48644 \\
\hline $\mathrm{C}$ & -3.33711 & -0.53587 & -2.59492 & $\mathrm{H}$ & 3.59172 & -2.84903 & 2.04122 \\
\hline $\mathrm{C}$ & 3.35651 & -0.68531 & -3.56801 & $\mathrm{H}$ & 4.40279 & -4.38924 & 2.42331 \\
\hline $\mathrm{H}$ & 3.31815 & -0.88895 & -4.64067 & $\mathrm{C}$ & 2.78681 & -4.83019 & 0.47499 \\
\hline $\mathrm{H}$ & 3.88355 & 0.25969 & -3.40605 & $\mathrm{H}$ & 3.62975 & -5.53934 & 0.44325 \\
\hline $\mathrm{C}$ & 4.08935 & -1.80974 & -2.83112 & $\mathrm{H}$ & 3.07855 & -3.91153 & -0.04433 \\
\hline $\mathrm{H}$ & 5.11113 & -1.88926 & -3.21742 & $\mathrm{C}$ & 1.60103 & -5.44872 & -0.22294 \\
\hline $\mathrm{H}$ & 3.60272 & -2.77377 & -3.01102 & $\mathrm{H}$ & 1.87723 & -5.66500 & -1.26494 \\
\hline $\mathrm{C}$ & -7.18243 & -2.19397 & 0.33483 & $\mathrm{H}$ & 1.30937 & -6.39034 & 0.26737 \\
\hline $\mathrm{H}$ & -8.01303 & -1.48678 & 0.23774 & $\mathrm{H}$ & -7.41306 & -3.10810 & -0.21294 \\
\hline $\mathrm{H}$ & -7.03746 & -2.44465 & 1.39290 & $\mathrm{H}$ & -8.94657 & -0.78101 & -3.01443 \\
\hline $\mathrm{C}$ & -8.02120 & -1.08044 & -3.50570 & $\mathrm{H}$ & 4.32372 & 6.80019 & -0.65430 \\
\hline $\mathrm{H}$ & -7.99334 & -2.17297 & -3.59316 & $\mathrm{H}$ & 8.56485 & 1.20899 & -3.51219 \\
\hline $\mathrm{H}$ & -7.98494 & -0.63516 & -4.50636 & $\mathrm{C}$ & -0.39780 & -0.20037 & 2.04796 \\
\hline $\mathrm{O}$ & 1.40918 & 0.01309 & -0.25376 & $\mathrm{C}$ & 0.52078 & 0.23425 & 3.00352 \\
\hline
\end{tabular}




$\begin{array}{lrrr}\mathrm{C} & -1.62514 & 0.45467 & 1.92872 \\ \mathrm{C} & 0.22466 & 1.32143 & 3.82224 \\ \mathrm{H} & 1.49504 & -0.24577 & 3.07552 \\ \mathrm{C} & -1.92267 & 1.53940 & 2.74955 \\ \mathrm{H} & -2.36394 & 0.09774 & 1.21362 \\ \mathrm{C} & -0.99452 & 1.98076 & 3.69170 \\ \mathrm{H} & 0.96963 & 1.68264 & 4.52412 \\ \mathrm{H} & -2.87909 & 2.04294 & 2.64612 \\ \mathrm{H} & -1.21548 & 2.84597 & 4.30874 \\ \mathrm{H} & -0.79129 & -1.46606 & 0.36104\end{array}$

(S)-2• L-phenylglycine

(binaphthyl gap occupied by phenyl group, gauche conformations for both ethylenediamine) $\Delta \mathrm{G}: 9.2 \mathrm{kcal} / \mathrm{mol}$

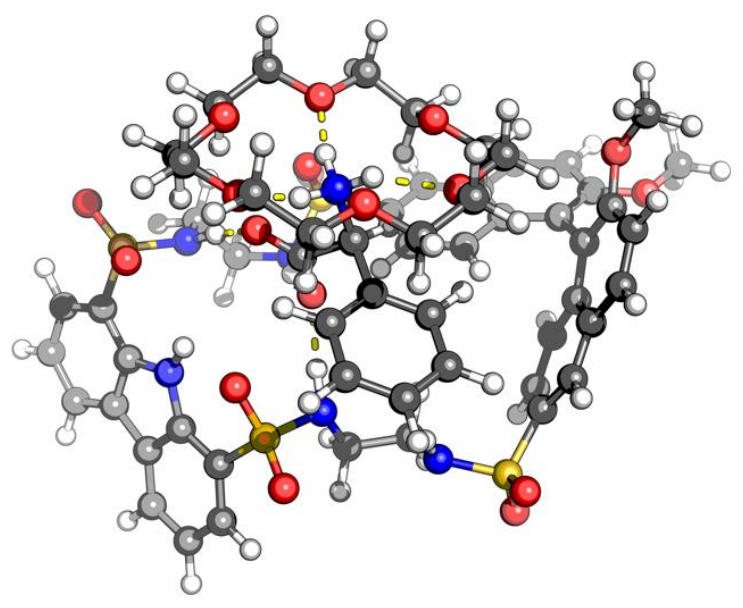

$\begin{array}{lr}\mathrm{S} & 2.97151 \\ \mathrm{~S} & -2.22323 \\ \mathrm{~S} & 0.48669 \\ \mathrm{~S} & 5.28644 \\ \mathrm{~N} & 4.93580 \\ \mathrm{H} & 4.37780 \\ \mathrm{~N} & 1.59671 \\ \mathrm{H} & 1.48602 \\ \mathrm{~N} & -0.75524 \\ \mathrm{H} & -0.57883 \\ \mathrm{~N} & 1.57430 \\ \mathrm{H} & 1.60850 \\ \mathrm{~N} & 3.82652 \\ \mathrm{H} & 3.05707 \\ \mathrm{O} & 2.77668 \\ \mathrm{O} & 3.29313 \\ \mathrm{O} & -2.49543 \\ \mathrm{O} & -2.19344 \\ \mathrm{O} & 0.56623 \\ \mathrm{O} & 0.63563 \\ \mathrm{O} & 5.10681 \\ \mathrm{O} & 5.89287 \\ \mathrm{O} & -6.64007\end{array}$

$\begin{array}{rr}3.13198 & 0.86449 \\ 5.32076 & -0.15247 \\ -2.50588 & -2.88117 \\ -2.17872 & -0.50315 \\ 0.99219 & -0.59264 \\ 0.56381 & 0.14178 \\ 2.83025 & 0.00163 \\ 1.82269 & -0.19342 \\ 4.57523 & -0.07902 \\ 4.11030 & 0.81106 \\ -1.26141 & -3.00634 \\ -0.74416 & -2.11103 \\ -2.04808 & -1.22527 \\ -1.94153 & -0.53892 \\ 4.37708 & 1.59015 \\ 1.88818 & 1.56059 \\ 5.79719 & 1.19511 \\ 6.20017 & -1.30868 \\ -3.12636 & -1.55184 \\ -3.35258 & -4.05960 \\ -1.66887 & 0.85256 \\ -3.48316 & -0.73400 \\ -1.38936 & -0.23341\end{array}$

\begin{tabular}{|c|c|c|c|}
\hline t & -7.34958 & -0.55532 & 998 \\
\hline $\mathrm{C}$ & 4.57784 & 4.70833 & -0.70447 \\
\hline $\mathrm{H}$ & 4.03055 & 5.52713 & -0.24766 \\
\hline $\mathrm{C}$ & 5.58126 & 4.95340 & -1.64810 \\
\hline $\mathrm{C}$ & 6.30778 & 3.90137 & -2.19051 \\
\hline $\mathrm{H}$ & 7.09230 & 4.09084 & -2.91707 \\
\hline $\mathrm{C}$ & 6.03338 & 2.59677 & -1.78290 \\
\hline $\mathrm{C}$ & 6.61345 & 1.31040 & -2.10350 \\
\hline $\mathrm{C}$ & 7.64961 & 0.89677 & -2.94389 \\
\hline $\mathrm{H}$ & 8.19438 & 1.62455 & -3.53789 \\
\hline $\mathrm{C}$ & 7.97834 & -0.44988 & -3.00874 \\
\hline $\mathrm{C}$ & 7.27454 & -1.39307 & -2.24607 \\
\hline $\mathrm{H}$ & 7.52074 & -2.44933 & -2.28635 \\
\hline $\mathrm{C}$ & 6.23952 & -0.99640 & -1.41430 \\
\hline $\mathrm{C}$ & 5.90765 & 0.36021 & -1.33353 \\
\hline $\mathrm{C}$ & 5.00866 & 2.34417 & -0.83641 \\
\hline $\mathrm{C}$ & 4.27810 & 3.41225 & -0.30157 \\
\hline $\mathrm{C}$ & 1.27961 & 3.73775 & -1.10065 \\
\hline $\mathrm{H}$ & 1.71450 & 3.38572 & -2.04457 \\
\hline $\mathrm{H}$ & 1.69357 & 4.72385 & -0.87224 \\
\hline $\mathrm{C}$ & -0.22733 & 3.88408 & -1.24763 \\
\hline $\mathrm{H}$ & -0.44423 & 4.49772 & -2.12667 \\
\hline $\mathrm{H}$ & -0.68685 & 2.89268 & -1.38569 \\
\hline $\mathrm{C}$ & -3.41197 & 4.04423 & -0.51279 \\
\hline $\mathrm{C}$ & -4.22419 & 3.57183 & 0.48093 \\
\hline $\mathrm{H}$ & -4.25168 & 4.07582 & 1.44308 \\
\hline $\mathrm{C}$ & -4.99518 & 2.39905 & 0.26350 \\
\hline $\mathrm{C}$ & -5.79333 & 1.83791 & 1.28588 \\
\hline $\mathrm{H}$ & -5.90657 & 2.37553 & 2.22297 \\
\hline $\mathrm{C}$ & -6.40128 & 0.61995 & 1.11300 \\
\hline $\mathrm{H}$ & -7.01068 & 0.20899 & 1.90883 \\
\hline $\mathrm{C}$ & -6.18407 & -0.11969 & -0.07621 \\
\hline $\mathrm{C}$ & -5.43626 & 0.41002 & -1.12171 \\
\hline $\mathrm{C}$ & -4.89090 & 1.71636 & -0.98174 \\
\hline $\mathrm{C}$ & -4.16594 & 2.34314 & -2.03884 \\
\hline $\mathrm{H}$ & -4.17059 & 1.88220 & -3.02095 \\
\hline $\mathrm{C}$ & -3.43697 & 3.47663 & -1.81279 \\
\hline $\mathrm{H}$ & -2.87776 & 3.95298 & -2.61146 \\
\hline $\mathrm{C}$ & -5.09136 & -0.45754 & -2.28093 \\
\hline $\mathrm{C}$ & -6.09045 & -0.98441 & -3.08761 \\
\hline $\mathrm{C}$ & -5.78405 & -1.91602 & -4.11036 \\
\hline $\mathrm{H}$ & -6.57095 & -2.32294 & -4.73288 \\
\hline $\mathrm{C}$ & -4.48800 & -2.31799 & -4.30852 \\
\hline $\mathrm{H}$ & -4.25863 & -3.04589 & -5.08139 \\
\hline $\mathrm{C}$ & -3.43308 & -1.79695 & -3.52511 \\
\hline $\mathrm{C}$ & -2.09385 & -2.24832 & -3.69508 \\
\hline $\mathrm{H}$ & -1.86718 & -3.03257 & -4.41251 \\
\hline $\mathrm{C}$ & -1.09817 & -1.70810 & -2.93040 \\
\hline $\mathrm{C}$ & -1.36185 & -0.68676 & -1.98718 \\
\hline $\mathrm{H}$ & -0.54740 & -0.24257 & -1.41994 \\
\hline $\mathrm{C}$ & -2.64921 & -0.29146 & -1.76869 \\
\hline $\mathrm{H}$ & -2.83450 & 0.45799 & -1.01013 \\
\hline $\mathrm{C}$ & -3.73706 & -0.83799 & -2.51413 \\
\hline $\mathrm{C}$ & 2.90523 & -1.68541 & -3.47154 \\
\hline $\mathrm{H}$ & 2.78934 & -2.13428 & -4.46061 \\
\hline
\end{tabular}




\begin{tabular}{|c|c|c|c|c|c|c|c|}
\hline $\mathrm{H}$ & 3.49856 & -0.77154 & -3.56354 & $\mathrm{H}$ & 2.91355 & -5.34532 & 1.26637 \\
\hline $\mathrm{C}$ & 3.61741 & -2.65806 & -2.53193 & $\mathrm{H}$ & 2.37528 & -3.79996 & 0.54763 \\
\hline $\mathrm{H}$ & 4.59462 & -2.90778 & -2.95886 & $\mathrm{C}$ & 0.81511 & -5.22052 & 0.87091 \\
\hline $\mathrm{H}$ & 3.05523 & -3.59479 & -2.44346 & $\mathrm{H}$ & 0.91904 & -5.62363 & -0.14605 \\
\hline $\mathrm{C}$ & -7.43194 & -1.95213 & 0.79022 & $\mathrm{H}$ & 0.55124 & -6.03886 & 1.55780 \\
\hline $\mathrm{H}$ & -8.34876 & -1.37444 & 0.95349 & $\mathrm{H}$ & -7.69167 & -2.95424 & 0.45072 \\
\hline $\mathrm{H}$ & -6.87754 & -2.02685 & 1.73506 & $\mathrm{H}$ & -9.32133 & -0.65891 & -3.19397 \\
\hline $\mathrm{C}$ & -8.41206 & -1.11964 & -3.57835 & $\mathrm{H}$ & 5.79615 & 5.97366 & -1.94465 \\
\hline $\mathrm{H}$ & -8.46631 & -2.20516 & -3.43508 & $\mathrm{H}$ & 8.78434 & -0.78098 & -3.65367 \\
\hline $\mathrm{H}$ & -8.32171 & -0.89810 & -4.64798 & $\mathrm{C}$ & -0.27707 & 0.63433 & 2.04435 \\
\hline $\mathrm{O}$ & 1.17719 & 0.04521 & -0.46087 & $\mathrm{C}$ & 0.78980 & 1.12278 & 2.79962 \\
\hline $\mathrm{O}$ & 1.99519 & -1.59328 & 0.83901 & $\mathrm{C}$ & -1.41604 & 1.42262 & 1.87654 \\
\hline $\mathrm{N}$ & -0.08739 & -1.81802 & 2.37815 & $\mathrm{C}$ & 0.72876 & 2.39091 & 3.37169 \\
\hline $\mathrm{H}$ & -0.93918 & -1.79645 & 2.95337 & $\mathrm{H}$ & 1.69902 & 0.53293 & 2.89550 \\
\hline $\mathrm{H}$ & 0.73712 & -1.75072 & 2.99693 & $\mathrm{C}$ & -1.48925 & 2.68045 & 2.47294 \\
\hline $\mathrm{H}$ & -0.01777 & -2.73289 & 1.89290 & $\mathrm{H}$ & -2.25855 & 1.04752 & 1.29750 \\
\hline $\mathrm{C}$ & -0.14079 & -0.71506 & 1.38064 & $\mathrm{C}$ & -0.41287 & 3.17243 & 3.21190 \\
\hline $\mathrm{C}$ & 1.13563 & -0.76688 & 0.50783 & $\mathrm{H}$ & 1.59070 & 2.78033 & 3.90405 \\
\hline $\mathrm{O}$ & -0.19903 & -4.23641 & 0.89032 & $\mathrm{H}$ & -2.37436 & 3.29536 & 2.34639 \\
\hline $\mathrm{O}$ & -2.62085 & -2.96984 & 1.38786 & $\mathrm{H}$ & -0.46281 & 4.16904 & 3.63920 \\
\hline $\mathrm{O}$ & -2.72988 & -0.98044 & 3.32425 & $\mathrm{H}$ & -1.00919 & -0.91490 & 0.74412 \\
\hline $\mathrm{O}$ & -0.63767 & -0.94290 & 5.14762 & & & & \\
\hline $\mathrm{O}$ & 1.94903 & -1.91484 & 4.46372 & & & & \\
\hline $\mathrm{O}$ & 1.97079 & -4.03216 & 2.56399 & & & & \\
\hline $\mathrm{C}$ & -1.37983 & -4.64858 & 0.24537 & & & & \\
\hline $\mathrm{H}$ & -1.87319 & -5.44481 & 0.82388 & & & & \\
\hline $\mathrm{H}$ & -1.14329 & -5.02484 & -0.75986 & & & & \\
\hline $\mathrm{C}$ & -2.29203 & -3.45861 & 0.09979 & & & & \\
\hline $\mathrm{H}$ & -1.77873 & -2.68655 & -0.48595 & & & & \\
\hline $\mathrm{H}$ & -3.20404 & -3.75528 & -0.44198 & & & & \\
\hline $\mathrm{C}$ & -3.60277 & -1.96336 & 1.34933 & & & & \\
\hline $\mathrm{H}$ & -4.52453 & -2.32659 & 0.86525 & & & & \\
\hline $\mathrm{H}$ & -3.25899 & -1.09074 & 0.77019 & & & & \\
\hline $\mathrm{C}$ & -3.89690 & -1.54878 & 2.76898 & & & & \\
\hline $\mathrm{H}$ & -4.71392 & -0.81092 & 2.77200 & & & & \\
\hline $\mathrm{H}$ & -4.20738 & -2.42641 & 3.35604 & & & & \\
\hline $\mathrm{C}$ & -2.92196 & -0.55031 & 4.65462 & & & & \\
\hline $\mathrm{H}$ & -3.21778 & -1.40343 & 5.28335 & & & & \\
\hline $\mathrm{H}$ & -3.71976 & 0.20736 & 4.69706 & & & & \\
\hline $\mathrm{C}$ & -1.64024 & 0.04988 & 5.17913 & & & & \\
\hline $\mathrm{H}$ & -1.34511 & 0.92129 & 4.58041 & & & & \\
\hline $\mathrm{H}$ & -1.81469 & 0.38546 & 6.21410 & & & & \\
\hline $\mathrm{C}$ & 0.54112 & -0.52218 & 5.80191 & & & & \\
\hline $\mathrm{H}$ & 0.31924 & -0.26051 & 6.84860 & & & & \\
\hline $\mathrm{H}$ & 0.95952 & 0.36543 & 5.30821 & & & & \\
\hline $\mathrm{C}$ & 1.54046 & -1.65056 & 5.78718 & & & & \\
\hline $\mathrm{H}$ & 2.40823 & -1.36614 & 6.40153 & & & & \\
\hline $\mathrm{H}$ & 1.08692 & -2.55047 & 6.22921 & & & & \\
\hline $\mathrm{C}$ & 2.93714 & -2.93533 & 4.41751 & & & & \\
\hline $\mathrm{H}$ & 2.60348 & -3.79229 & 5.02081 & & & & \\
\hline $\mathrm{H}$ & 3.87875 & -2.55370 & 4.83675 & & & & \\
\hline $\mathrm{C}$ & 3.15026 & -3.37849 & 2.99382 & & & & \\
\hline $\mathrm{H}$ & 3.38464 & -2.52639 & 2.34674 & & & & \\
\hline $\mathrm{H}$ & 4.00375 & -4.07474 & 2.96981 & & & & \\
\hline $\mathrm{C}$ & 2.11992 & -4.58093 & 1.27196 & & & & \\
\hline
\end{tabular}


$(S)$-2• L-phenylglycine

(binaphthyl gap occupied by phenyl group, alternative)

$\Delta \mathrm{G}: 16.9 \mathrm{kcal} / \mathrm{mol}$

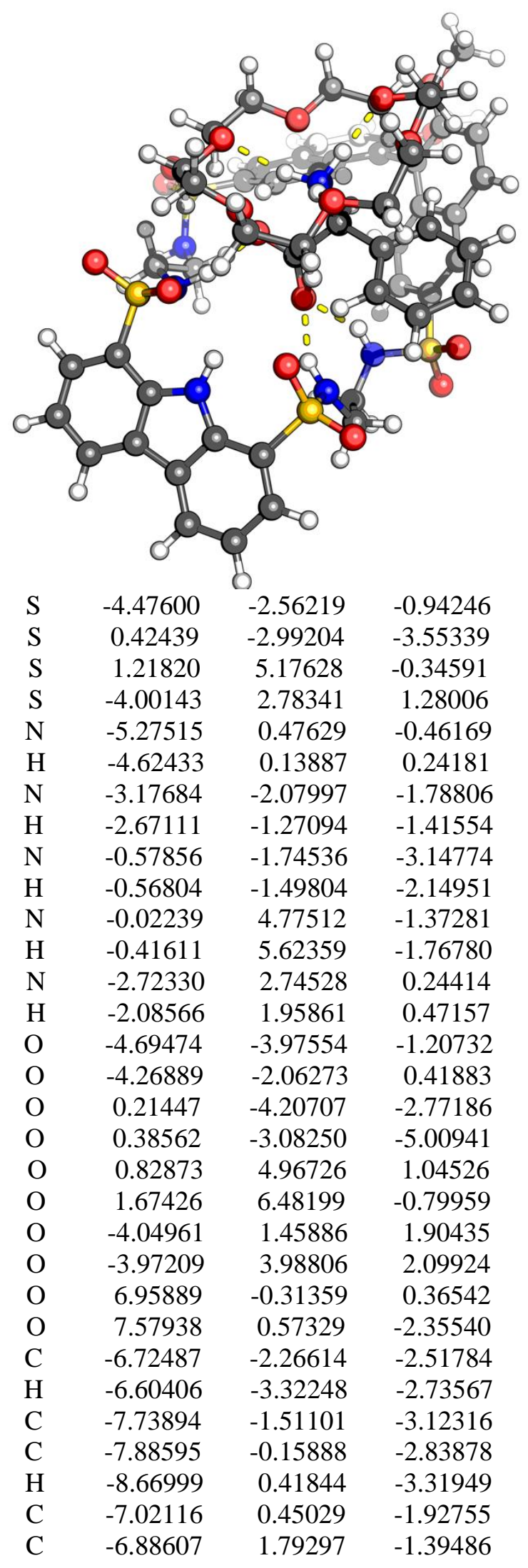

$\mathrm{C}$

C

$\mathrm{C}$

C

$\mathrm{H}$

$\mathrm{H}$

C

$\mathrm{H}$

$\mathrm{H}$

$\mathrm{H}$

C

C

$\mathrm{H}$

C

$\mathrm{H}$

C

$$
\begin{aligned}
& \mathrm{C} \\
& \mathrm{C}
\end{aligned}
$$$$
\text { C }
$$$$
\mathrm{C}
$$

$\mathrm{H}$

$\mathrm{C}$

$$
\text { C }
$$$$
\text { C }
$$$$
\text { C }
$$$$
\mathrm{H}
$$$$
\text { C }
$$$$
\begin{aligned}
& \mathrm{C} \\
& \mathrm{H}
\end{aligned}
$$$$
\text { C }
$$$$
\text { C }
$$$$
\text { C }
$$$$
\text { C }
$$$$
\text { C }
$$$$
\text { C }
$$$$
\text { C }
$$$$
\text { C }
$$$$
\text { C }
$$$$
\mathrm{H}
$$$$
\mathrm{H}
$$$$
\text { H }
$$$$
\text { C }
$$$$
\begin{aligned}
& \mathrm{C} \\
& \mathrm{H}
\end{aligned}
$$

\begin{tabular}{|c|c|c|}
\hline-7.57135 & 2.99586 & -1.58139 \\
\hline-8.40879 & 3.04740 & -2.27064 \\
\hline-7.17948 & 4.12357 & -0.87092 \\
\hline-6.10011 & 4.07122 & 0.02315 \\
\hline-5.79689 & 4.94510 & 0.59099 \\
\hline-5.40507 & 2.88713 & 0.20928 \\
\hline-5.80007 & 1.74530 & -0.49267 \\
\hline-6.00642 & -0.31784 & -1.31028 \\
\hline-5.85551 & -1.67463 & -1.61221 \\
\hline-2.95716 & -2.53115 & -3.15821 \\
\hline-3.88423 & -2.44035 & -3.74211 \\
\hline-2.64792 & -3.58170 & -3.15190 \\
\hline-1.88030 & -1.66125 & -3.79801 \\
\hline-1.74959 & -1.94245 & -4.84566 \\
\hline-2.18930 & -0.61115 & -3.76181 \\
\hline 1.94951 & -2.27153 & -2.99404 \\
\hline 2.73611 & -2.97383 & -2.12676 \\
\hline 2.44544 & -3.97836 & -1.83415 \\
\hline 3.88456 & -2.35454 & -1.56404 \\
\hline 4.71220 & -3.03342 & -0.63919 \\
\hline 4.49491 & -4.07329 & -0.40733 \\
\hline 5.76763 & -2.39778 & -0.03482 \\
\hline 6.38549 & -2.93737 & 0.67324 \\
\hline 6.01459 & -1.02697 & -0.30216 \\
\hline 5.24730 & -0.32926 & -1.22224 \\
\hline 4.18749 & -1.00364 & -1.89673 \\
\hline 3.38855 & -0.35102 & -2.88366 \\
\hline 3.64868 & 0.65349 & -3.19503 \\
\hline 2.29214 & -0.96478 & -3.41835 \\
\hline 1.65969 & -0.45901 & -4.13963 \\
\hline 5.48911 & 1.11634 & -1.47876 \\
\hline 6.66622 & 1.53501 & -2.08143 \\
\hline 6.86671 & 2.90009 & -2.41140 \\
\hline 7.78823 & 3.21845 & -2.88269 \\
\hline 5.88344 & 3.82171 & -2.16035 \\
\hline 6.03130 & 4.86170 & -2.43624 \\
\hline 4.66675 & 3.44152 & -1.54746 \\
\hline 3.62932 & 4.38020 & -1.30461 \\
\hline 3.74704 & 5.41908 & -1.59955 \\
\hline 2.47774 & 3.97361 & -0.68674 \\
\hline 2.30206 & 2.63766 & -0.24630 \\
\hline 1.41571 & 2.32670 & 0.29989 \\
\hline 3.27983 & 1.72011 & -0.50588 \\
\hline 3.14078 & 0.69689 & -0.17768 \\
\hline 4.48435 & 2.07857 & -1.17645 \\
\hline-0.94373 & 3.68212 & -1.06564 \\
\hline-1.43831 & 3.39871 & -1.99872 \\
\hline-0.36275 & 2.81017 & -0.75255 \\
\hline-1.99275 & 3.99294 & 0.00428 \\
\hline-2.69228 & 4.75573 & -0.35737 \\
\hline-1.51116 & 4.37273 & 0.91200 \\
\hline 7.90327 & -1.01852 & 1.14188 \\
\hline 8.42587 & -1.77481 & 0.54528 \\
\hline 7.43668 & -1.50327 & 2.00926 \\
\hline 8.79301 & 0.94998 & -2.97073 \\
\hline
\end{tabular}

$\mathrm{H}$




\begin{tabular}{|c|c|c|c|}
\hline $\mathrm{H}$ & 9.36052 & 1.64832 & -2.34471 \\
\hline $\mathrm{H}$ & 8.62269 & 1.40001 & -3.95538 \\
\hline $\mathrm{O}$ & -1.09705 & -0.33977 & -0.75504 \\
\hline $\mathrm{O}$ & -0.58940 & 1.07150 & 0.90989 \\
\hline $\mathrm{N}$ & 0.42235 & -0.83025 & 2.45813 \\
\hline $\mathrm{H}$ & -0.34312 & -1.34102 & 2.92738 \\
\hline $\mathrm{H}$ & 0.29229 & 0.17879 & 2.66228 \\
\hline $\mathrm{H}$ & 1.30655 & -1.14343 & 2.88216 \\
\hline $\mathrm{C}$ & 0.42947 & -1.05833 & 0.97759 \\
\hline $\mathrm{C}$ & -0.53355 & -0.02947 & 0.31353 \\
\hline $\mathrm{O}$ & 2.45719 & 1.15391 & 2.49890 \\
\hline $\mathrm{O}$ & 3.22886 & -1.40263 & 3.25624 \\
\hline $\mathrm{O}$ & 1.39177 & -3.38173 & 3.72860 \\
\hline $\mathrm{O}$ & -1.34664 & -2.66883 & 3.92216 \\
\hline $\mathrm{O}$ & -2.10392 & -0.12212 & 3.57476 \\
\hline $\mathrm{O}$ & 0.00484 & 1.79967 & 3.74317 \\
\hline $\mathrm{C}$ & 3.81616 & 0.79785 & 2.59716 \\
\hline $\mathrm{H}$ & 4.18111 & 0.98726 & 3.61797 \\
\hline $\mathrm{H}$ & 4.43235 & 1.38172 & 1.89472 \\
\hline $\mathrm{C}$ & 3.97768 & -0.67321 & 2.30278 \\
\hline $\mathrm{H}$ & 3.64800 & -0.92784 & 1.28226 \\
\hline $\mathrm{H}$ & 5.04646 & -0.92725 & 2.37252 \\
\hline $\mathrm{C}$ & 3.63980 & -2.74483 & 3.39636 \\
\hline $\mathrm{H}$ & 4.65544 & -2.78893 & 3.81936 \\
\hline $\mathrm{H}$ & 3.65295 & -3.25330 & 2.42132 \\
\hline $\mathrm{C}$ & 2.66447 & -3.43198 & 4.32293 \\
\hline $\mathrm{H}$ & 2.98599 & -4.47411 & 4.47823 \\
\hline $\mathrm{H}$ & 2.65662 & -2.92553 & 5.30038 \\
\hline $\mathrm{C}$ & 0.43200 & -4.14661 & 4.42619 \\
\hline $\mathrm{H}$ & 0.35631 & -3.80393 & 5.46926 \\
\hline $\mathrm{H}$ & 0.72415 & -5.20825 & 4.42852 \\
\hline $\mathrm{C}$ & -0.90858 & -3.99989 & 3.74702 \\
\hline $\mathrm{H}$ & -0.82163 & -4.25419 & 2.68318 \\
\hline $\mathrm{H}$ & -1.62162 & -4.69615 & 4.21449 \\
\hline $\mathrm{C}$ & -2.66262 & -2.42117 & 3.44445 \\
\hline $\mathrm{H}$ & -3.35661 & -3.18624 & 3.82131 \\
\hline $\mathrm{H}$ & -2.69453 & -2.44436 & 2.34920 \\
\hline $\mathrm{C}$ & -3.07206 & -1.06578 & 3.97116 \\
\hline $\mathrm{H}$ & -4.06098 & -0.78838 & 3.57900 \\
\hline $\mathrm{H}$ & -3.12350 & -1.11050 & 5.07031 \\
\hline $\mathrm{C}$ & -2.21543 & 1.07433 & 4.31704 \\
\hline $\mathrm{H}$ & -1.89979 & 0.89709 & 5.35751 \\
\hline $\mathrm{H}$ & -3.25600 & 1.42592 & 4.31369 \\
\hline $\mathrm{C}$ & -1.36987 & 2.14534 & 3.68500 \\
\hline $\mathrm{H}$ & -1.66479 & 2.26615 & 2.63880 \\
\hline $\mathrm{H}$ & -1.54018 & 3.09722 & 4.21016 \\
\hline $\mathrm{C}$ & 0.75615 & 2.77132 & 3.03980 \\
\hline $\mathrm{H}$ & 0.62576 & 3.76448 & 3.49522 \\
\hline $\mathrm{H}$ & 0.39558 & 2.83579 & 2.01027 \\
\hline $\mathrm{C}$ & 2.22167 & 2.42666 & 3.08348 \\
\hline $\mathrm{H}$ & 2.77509 & 3.20576 & 2.53661 \\
\hline $\mathrm{H}$ & 2.57169 & 2.41146 & 4.12630 \\
\hline $\mathrm{H}$ & 8.61782 & -0.27562 & 1.49471 \\
\hline $\mathrm{H}$ & 9.36333 & 0.02968 & -3.09208 \\
\hline $\mathrm{H}$ & -8.41153 & -1.99133 & -3.82468 \\
\hline
\end{tabular}

$\begin{array}{lrrr}\mathrm{H} & -7.71247 & 5.05811 & -1.00417 \\ \mathrm{C} & 0.19587 & -2.51394 & 0.65867 \\ \mathrm{C} & 1.26744 & -3.40484 & 0.68733 \\ \mathrm{C} & -1.08030 & -3.00478 & 0.38325 \\ \mathrm{C} & 1.07029 & -4.76273 & 0.45697 \\ \mathrm{H} & 2.26570 & -3.01913 & 0.88386 \\ \mathrm{C} & -1.28076 & -4.35612 & 0.11338 \\ \mathrm{H} & -1.92051 & -2.32557 & 0.36226 \\ \mathrm{C} & -0.20473 & -5.23891 & 0.15799 \\ \mathrm{H} & 1.91495 & -5.44592 & 0.48750 \\ \mathrm{H} & -2.27839 & -4.70557 & -0.13958 \\ \mathrm{H} & -0.35460 & -6.29131 & -0.05976 \\ \mathrm{H} & 1.43442 & -0.76919 & 0.64206\end{array}$

(S)-2•D-phenylalanine $\Delta \mathrm{G}: 0.0 \mathrm{kcal} / \mathrm{mol}$

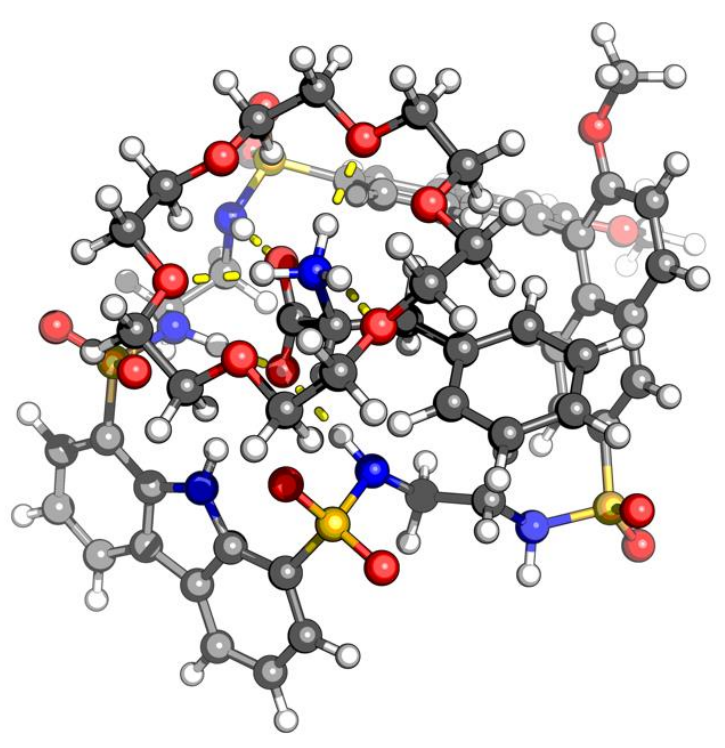

$\begin{array}{lrrr}\mathrm{S} & 2.42486 & 3.36885 & -0.37296 \\ \mathrm{~S} & -3.26937 & 4.95412 & -1.81476 \\ \mathrm{~S} & -0.11360 & -5.15773 & -1.10956 \\ \mathrm{~S} & 4.91012 & -2.03639 & -0.94646 \\ \mathrm{~N} & 4.30469 & 1.05520 & -1.63933 \\ \mathrm{~N} & 1.10186 & 2.49649 & -0.80245 \\ \mathrm{~N} & -1.69961 & 4.53486 & -2.18463 \\ \mathrm{~N} & 1.24228 & -4.22514 & -1.17781 \\ \mathrm{~N} & 3.38365 & -2.43351 & -1.35706 \\ \mathrm{O} & 1.99259 & 4.72680 & -0.07836 \\ \mathrm{O} & 3.10479 & 2.56241 & 0.64123 \\ \mathrm{O} & -3.77703 & 5.58917 & -3.02195 \\ \mathrm{O} & -3.37358 & 5.64486 & -0.53533 \\ \mathrm{O} & -0.20006 & -5.66015 & 0.25419 \\ \mathrm{O} & -0.07685 & -6.06397 & -2.24835 \\ \mathrm{O} & 4.79296 & -1.14650 & 0.20626 \\ \mathrm{O} & 5.70413 & -3.25275 & -0.88469 \\ \mathrm{O} & -6.32097 & -2.12979 & 0.59031 \\ \mathrm{O} & -6.93140 & -1.14574 & -2.87461\end{array}$




\begin{tabular}{|c|c|c|c|c|c|c|c|}
\hline $\mathrm{C}$ & 3.57926 & 4.60892 & -2.52716 & $\mathrm{C}$ & -2.21672 & -0.68654 & 4.34034 \\
\hline $\mathrm{C}$ & 4.38076 & 4.66827 & -3.67339 & $\mathrm{C}$ & -1.95079 & -2.17277 & 4.35582 \\
\hline $\mathrm{C}$ & 5.09865 & 3.55440 & -4.08875 & $\mathrm{C}$ & -0.51547 & -3.85789 & 3.59633 \\
\hline $\mathrm{C}$ & 5.02132 & 2.37207 & -3.35270 & $\mathrm{C}$ & 0.68033 & -4.14144 & 2.72814 \\
\hline $\mathrm{C}$ & 5.62302 & 1.06435 & -3.49699 & $\mathrm{C}$ & 2.92840 & -3.67954 & 2.39968 \\
\hline $\mathrm{C}$ & 6.50034 & 0.50236 & -4.42702 & $\mathrm{C}$ & 4.08993 & -2.86864 & 2.90658 \\
\hline $\mathrm{C}$ & 6.89844 & -0.81798 & -4.27532 & $\mathrm{C}$ & 4.87379 & -0.66990 & 3.10222 \\
\hline $\mathrm{C}$ & 6.42578 & -1.58646 & -3.20231 & $\mathrm{C}$ & 4.44767 & 0.75795 & 2.89738 \\
\hline $\mathrm{C}$ & 5.55521 & -1.04249 & -2.26940 & $\mathrm{C}$ & 3.10714 & 2.40247 & 3.92835 \\
\hline $\mathrm{C}$ & 5.14667 & 0.28984 & -2.41484 & $\mathrm{C}$ & 2.09565 & 2.56556 & 5.03536 \\
\hline $\mathrm{C}$ & 4.21393 & 2.30867 & -2.19035 & $\mathrm{H}$ & 3.02504 & 5.47694 & -2.18505 \\
\hline $\mathrm{C}$ & 3.49075 & 3.43879 & -1.78341 & $\mathrm{H}$ & 4.43841 & 5.59340 & -4.23521 \\
\hline $\mathrm{C}$ & 0.18235 & 3.07585 & -1.77927 & $\mathrm{H}$ & 5.71821 & 3.60106 & -4.97934 \\
\hline $\mathrm{C}$ & -0.85729 & 3.98251 & -1.11922 & $\mathrm{H}$ & 6.86696 & 1.09544 & -5.25954 \\
\hline $\mathrm{C}$ & -3.95481 & 3.33346 & -1.58507 & $\mathrm{H}$ & 7.58338 & -1.26309 & -4.98800 \\
\hline $\mathrm{C}$ & -4.72672 & 3.10630 & -0.48045 & $\mathrm{H}$ & 6.74260 & -2.61571 & -3.06668 \\
\hline $\mathrm{C}$ & -5.20963 & 1.79906 & -0.21841 & $\mathrm{H}$ & -6.90163 & 0.01933 & 2.13984 \\
\hline $\mathrm{C}$ & -5.96041 & 1.50617 & 0.94364 & $\mathrm{H}$ & -7.10481 & -3.53178 & 1.79059 \\
\hline $\mathrm{C}$ & -6.33442 & 0.21969 & 1.23917 & $\mathrm{H}$ & -6.37647 & -2.16197 & 2.66884 \\
\hline $\mathrm{C}$ & -5.99034 & -0.83654 & 0.35781 & $\mathrm{H}$ & -7.96107 & -1.97057 & 1.86175 \\
\hline $\mathrm{C}$ & -5.28551 & -0.58602 & -0.80881 & $\mathrm{H}$ & -8.28204 & -2.31806 & -3.93793 \\
\hline $\mathrm{C}$ & -4.87425 & 0.73834 & -1.10746 & $\mathrm{H}$ & -8.59596 & -0.56671 & -3.83189 \\
\hline $\mathrm{C}$ & -4.10377 & 1.03540 & -2.27125 & $\mathrm{H}$ & -7.31999 & -1.17204 & -4.91843 \\
\hline $\mathrm{C}$ & -3.65409 & 2.30334 & -2.51137 & $\mathrm{H}$ & -6.25501 & -3.16962 & -4.55119 \\
\hline $\mathrm{C}$ & -4.97510 & -1.70129 & -1.74424 & $\mathrm{H}$ & -4.23477 & -4.53701 & -4.30822 \\
\hline $\mathrm{C}$ & -5.84093 & -1.94879 & -2.79766 & $\mathrm{H}$ & -2.15132 & -5.12040 & -3.08189 \\
\hline $\mathrm{C}$ & -5.57301 & -2.97980 & -3.73172 & $\mathrm{H}$ & -3.07773 & -1.47274 & 0.17615 \\
\hline $\mathrm{C}$ & -4.44308 & -3.74434 & -3.59547 & $\mathrm{H}$ & -1.05785 & -2.86550 & 0.41367 \\
\hline $\mathrm{C}$ & -3.53318 & -3.52333 & -2.53620 & $\mathrm{H}$ & -6.23645 & 2.31822 & 1.61088 \\
\hline $\mathrm{C}$ & -2.36605 & -4.31588 & -2.38434 & $\mathrm{H}$ & -4.92150 & 3.91713 & 0.21496 \\
\hline $\mathrm{C}$ & -1.51615 & -4.08066 & -1.33990 & $\mathrm{H}$ & -3.86276 & 0.22998 & -2.95672 \\
\hline $\mathrm{C}$ & -1.75906 & -3.04584 & -0.39815 & $\mathrm{H}$ & -3.04740 & 2.53376 & -3.38062 \\
\hline $\mathrm{C}$ & -2.87606 & -2.26892 & -0.53480 & $\mathrm{H}$ & -1.48905 & 3.38713 & -0.44978 \\
\hline $\mathrm{C}$ & -3.80336 & -2.48749 & -1.59638 & $\mathrm{H}$ & -0.37587 & 4.75724 & -0.51612 \\
\hline $\mathrm{C}$ & 1.63745 & -3.67367 & -2.47105 & $\mathrm{H}$ & -0.32908 & 2.25011 & -2.28125 \\
\hline $\mathrm{C}$ & 3.12952 & -3.36416 & -2.44934 & $\mathrm{H}$ & 0.72740 & 3.63286 & -2.55695 \\
\hline $\mathrm{C}$ & -6.97743 & -2.45009 & 1.79771 & $\mathrm{H}$ & 3.69481 & -4.27912 & -2.25793 \\
\hline $\mathrm{C}$ & -7.82209 & -1.32306 & -3.95585 & $\mathrm{H}$ & 3.42961 & -2.95219 & -3.42462 \\
\hline $\mathrm{N}$ & 1.10705 & -0.46772 & 2.88613 & $\mathrm{H}$ & 1.43379 & -4.42101 & -3.24090 \\
\hline $\mathrm{H}$ & 0.47916 & -1.28364 & 2.96593 & $\mathrm{H}$ & 1.07138 & -2.76028 & -2.70902 \\
\hline $\mathrm{H}$ & 2.07566 & -0.82577 & 2.99869 & $\mathrm{H}$ & -1.67467 & -2.47142 & 5.37782 \\
\hline $\mathrm{H}$ & 0.91291 & 0.19211 & 3.65353 & $\mathrm{H}$ & -2.87021 & -2.71096 & 4.07676 \\
\hline $\mathrm{O}$ & 1.11122 & -1.96228 & 0.64231 & $\mathrm{H}$ & -2.47429 & -0.34258 & 3.32833 \\
\hline $\mathrm{O}$ & 1.86342 & -0.23686 & -0.59213 & $\mathrm{H}$ & -3.08241 & -0.48562 & 4.99095 \\
\hline $\mathrm{C}$ & -0.50355 & 0.54620 & 1.26311 & $\mathrm{H}$ & -0.27250 & -4.06076 & 4.64940 \\
\hline $\mathrm{C}$ & 0.96090 & 0.20107 & 1.56602 & $\mathrm{H}$ & -1.34327 & -4.51329 & 3.28940 \\
\hline $\mathrm{C}$ & 1.38237 & -0.76499 & 0.45489 & $\mathrm{H}$ & 0.88024 & -5.22343 & 2.75067 \\
\hline $\mathrm{O}$ & -1.07411 & -0.01537 & 4.82159 & $\mathrm{H}$ & 0.46226 & -3.87440 & 1.69213 \\
\hline $\mathrm{O}$ & -0.90940 & -2.49668 & 3.46213 & $\mathrm{H}$ & 3.18780 & -4.74849 & 2.45063 \\
\hline $\mathrm{O}$ & 1.79166 & -3.41257 & 3.20087 & $\mathrm{H}$ & 2.73228 & -3.41750 & 1.35262 \\
\hline $\mathrm{O}$ & 3.76341 & -1.49655 & 2.82821 & $\mathrm{H}$ & 4.96495 & -3.07593 & 2.27359 \\
\hline $\mathrm{O}$ & 3.41494 & 1.03268 & 3.82972 & $\mathrm{H}$ & 4.32788 & -3.13379 & 3.94801 \\
\hline $\mathrm{O}$ & 0.90835 & 1.88137 & 4.68810 & $\mathrm{H}$ & 5.69355 & -0.90902 & 2.41390 \\
\hline $\mathrm{C}$ & -0.04867 & 1.91543 & 5.72336 & $\mathrm{H}$ & 5.20643 & -0.82097 & 4.14078 \\
\hline $\mathrm{C}$ & -1.33723 & 1.31676 & 5.21686 & $\mathrm{H}$ & 5.30386 & 1.42805 & 3.06750 \\
\hline
\end{tabular}




$\begin{array}{lrrr}\mathrm{H} & 4.09549 & 0.90124 & 1.86836 \\ \mathrm{H} & 4.00668 & 2.98446 & 4.18557 \\ \mathrm{H} & 2.72479 & 2.79048 & 2.97524 \\ \mathrm{H} & 2.50579 & 2.15271 & 5.96891 \\ \mathrm{H} & 1.88065 & 3.63402 & 5.18959 \\ \mathrm{H} & 0.31928 & 1.35053 & 6.59305 \\ \mathrm{H} & -0.23734 & 2.95358 & 6.03657 \\ \mathrm{H} & -1.72260 & 1.90902 & 4.37800 \\ \mathrm{H} & -2.08265 & 1.33302 & 6.02776 \\ \mathrm{H} & -1.28386 & 5.29004 & -2.72494 \\ \mathrm{H} & 1.33284 & 1.48997 & -0.87797 \\ \mathrm{H} & 2.73894 & -1.62907 & -1.24410 \\ \mathrm{H} & 3.82037 & 0.72947 & -0.80430 \\ \mathrm{H} & 1.27742 & -3.52392 & -0.42382 \\ \mathrm{H} & 1.61697 & 1.07299 & 1.56097 \\ \mathrm{H} & -1.11364 & -0.31472 & 1.56955 \\ \mathrm{H} & -0.59890 & 0.59300 & 0.17000 \\ \mathrm{C} & -1.07543 & 1.82918 & 1.81788 \\ \mathrm{C} & -2.46524 & 1.96192 & 1.90104 \\ \mathrm{C} & -0.28223 & 2.92952 & 2.14707 \\ \mathrm{C} & -3.04483 & 3.15400 & 2.32634 \\ \mathrm{H} & -3.10361 & 1.12598 & 1.61683 \\ \mathrm{C} & -0.85908 & 4.12489 & 2.56726 \\ \mathrm{H} & 0.79613 & 2.86535 & 2.05980 \\ \mathrm{C} & -2.24313 & 4.24308 & 2.66002 \\ \mathrm{H} & -4.12551 & 3.23120 & 2.39258 \\ \mathrm{H} & -0.22053 & 4.97205 & 2.79776 \\ \mathrm{H} & -2.69481 & 5.17987 & 2.96847\end{array}$

$(S)$-2• D-phenylalanine (alternative gauche conformations for both ethylenediamine) $\Delta \mathrm{G}: 2.5 \mathrm{kcal} / \mathrm{mol}$

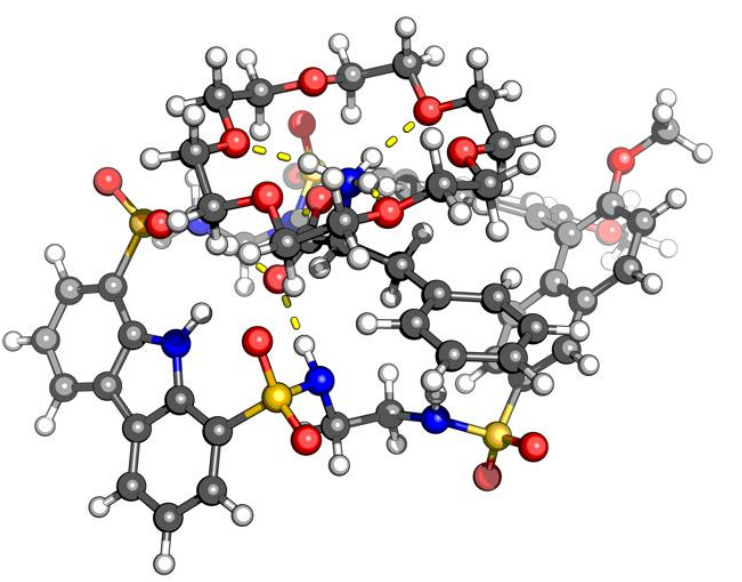

$\begin{array}{lrrr}\mathrm{S} & -3.35496 & -2.78210 & -1.17619 \\ \mathrm{~S} & 2.06376 & -3.69804 & -3.21819 \\ \mathrm{~S} & 0.54140 & 4.64314 & -0.34121 \\ \mathrm{~S} & -4.70093 & 2.83723 & 0.41642 \\ \mathrm{~N} & -4.83411 & 0.10459 & -1.29713 \\ \mathrm{H} & -4.20599 & 0.03802 & -0.49727 \\ \mathrm{~N} & -1.96250 & -2.02225 & -1.63609 \\ \mathrm{H} & -1.97755 & -1.05000 & -1.27600 \\ \mathrm{~N} & 0.59668 & -3.21648 & -2.63232 \\ \mathrm{H} & 0.44353 & -3.42961 & -1.64757 \\ \mathrm{~N} & -0.44634 & 3.50626 & -1.03120 \\ \mathrm{H} & -0.61188 & 2.74910 & -0.34692 \\ \mathrm{~N} & -3.16229 & 3.08412 & -0.05985 \\ \mathrm{H} & -2.70662 & 2.19087 & -0.31018 \\ \mathrm{O} & -3.19197 & -4.21073 & -1.38302 \\ \mathrm{O} & -3.65561 & -2.25237 & 0.15619 \\ \mathrm{O} & 2.34488 & -4.99178 & -2.62128 \\ \mathrm{O} & 2.00470 & -3.49920 & -4.65790 \\ \mathrm{O} & 0.24539 & 4.80193 & 1.08141 \\ \mathrm{O} & 0.54053 & 5.81665 & -1.20700 \\ \mathrm{O} & -4.68981 & 1.59542 & 1.18375 \\ \mathrm{O} & -5.20794 & 4.07739 & 0.97999 \\ \mathrm{O} & 7.45918 & 0.80753 & 0.80805 \\ \mathrm{O} & 7.86099 & 1.61252 & -2.02086 \\ \mathrm{C} & -5.06408 & -3.04146 & -3.29750 \\ \mathrm{H} & -4.67741 & -4.05466 & -3.33968 \\ \mathrm{C} & -5.99736 & -2.58341 & -4.23468 \\ \mathrm{C} & -6.48104 & -1.28334 & -4.16838 \\ \mathrm{H} & -7.19914 & -0.92619 & -4.90049 \\ \mathrm{C} & -6.03904 & -0.43609 & -3.15235 \\ \mathrm{C} & -6.33331 & 0.93518 & -2.79813 \\ \mathrm{C} & -7.16421 & 1.91431 & -3.34686 \\ \mathrm{H} & -7.75132 & 1.69609 & -4.23386 \\ \mathrm{C} & -7.23583 & 3.16189 & -2.74487 \\ \mathrm{C} & -6.48621 & 3.44052 & -1.59323 \\ \mathrm{H} & -6.55810 & 4.40310 & -1.09666\end{array}$




\begin{tabular}{|c|c|c|c|c|c|c|c|}
\hline $\mathrm{C}$ & -5.65355 & 2.47989 & -1.03813 & $\mathrm{H}$ & -0.63950 & -1.39943 & 3.31749 \\
\hline $\mathrm{C}$ & -5.56819 & 1.21800 & -1.64358 & $\mathrm{H}$ & -1.54893 & 0.01229 & 3.18234 \\
\hline $\mathrm{C}$ & -5.10405 & -0.89921 & -2.19423 & $\mathrm{H}$ & 0.09398 & 0.06890 & 2.94720 \\
\hline $\mathrm{C}$ & -4.61613 & -2.21083 & -2.27818 & $\mathrm{C}$ & 0.31076 & -1.33000 & 0.68631 \\
\hline $\mathrm{C}$ & -1.57149 & -2.16517 & -3.04285 & C & -0.96264 & -0.78691 & 1.34956 \\
\hline $\mathrm{H}$ & -2.06677 & -1.41013 & -3.66691 & $\mathrm{H}$ & -1.81526 & -1.46184 & 1.25786 \\
\hline $\mathrm{H}$ & -1.87087 & -3.15916 & -3.38715 & $\mathrm{C}$ & -1.26706 & 0.53197 & 0.63547 \\
\hline $\mathrm{C}$ & -0.06238 & -2.04185 & -3.18623 & $\mathrm{O}$ & 1.81707 & 0.70876 & 3.52550 \\
\hline $\mathrm{H}$ & 0.18851 & -2.00516 & -4.24937 & $\mathrm{O}$ & 1.39535 & -2.04685 & 4.10703 \\
\hline $\mathrm{H}$ & 0.27983 & -1.10547 & -2.71878 & $\mathrm{O}$ & -1.01289 & -3.31455 & 3.80605 \\
\hline $\mathrm{C}$ & 3.26598 & -2.55174 & -2.58309 & $\mathrm{O}$ & -3.23637 & -1.67562 & 3.68497 \\
\hline $\mathrm{C}$ & 4.17940 & -2.97565 & -1.65881 & $\mathrm{O}$ & -2.98364 & 1.08942 & 3.41077 \\
\hline $\mathrm{H}$ & 4.20591 & -4.02338 & -1.37487 & $\mathrm{O}$ & -0.53826 & 2.28933 & 3.91152 \\
\hline $\mathrm{C}$ & 5.06193 & -2.04211 & -1.05481 & $\mathrm{C}$ & 2.77143 & -0.11025 & 4.16415 \\
\hline $\mathrm{C}$ & 5.98533 & -2.43880 & -0.06004 & $\mathrm{H}$ & 2.62029 & -0.08231 & 5.25344 \\
\hline $\mathrm{H}$ & 6.04288 & -3.48845 & 0.21522 & $\mathrm{H}$ & 3.78776 & 0.25476 & 3.94771 \\
\hline $\mathrm{C}$ & 6.79604 & -1.52129 & 0.55798 & $\mathrm{C}$ & 2.64420 & -1.53803 & 3.69321 \\
\hline $\mathrm{H}$ & 7.49317 & -1.85065 & 1.31853 & $\mathrm{H}$ & 2.75083 & -1.60005 & 2.60156 \\
\hline $\mathrm{C}$ & 6.71158 & -0.14969 & 0.20832 & $\mathrm{H}$ & 3.46292 & -2.12140 & 4.14245 \\
\hline $\mathrm{C}$ & 5.82347 & 0.28353 & -0.76503 & $\mathrm{C}$ & 1.33696 & -3.45966 & 4.09999 \\
\hline $\mathrm{C}$ & 4.99235 & -0.66694 & -1.42183 & $\mathrm{H}$ & 2.12009 & -3.87614 & 4.75310 \\
\hline $\mathrm{C}$ & 4.07477 & -0.28727 & -2.44788 & $\mathrm{H}$ & 1.47957 & -3.85660 & 3.08813 \\
\hline $\mathrm{H}$ & 4.05218 & 0.74464 & -2.77868 & $\mathrm{C}$ & -0.01339 & -3.87195 & 4.62950 \\
\hline $\mathrm{C}$ & 3.23322 & -1.20223 & -3.01684 & $\mathrm{H}$ & -0.07844 & -4.97065 & 4.62394 \\
\hline $\mathrm{H}$ & 2.55641 & -0.91049 & -3.81352 & $\mathrm{H}$ & -0.14217 & -3.52068 & 5.66449 \\
\hline $\mathrm{C}$ & 5.72056 & 1.72817 & -1.10487 & $\mathrm{C}$ & -2.30284 & -3.78412 & 4.14253 \\
\hline $\mathrm{C}$ & 6.75705 & 2.36007 & -1.77618 & $\mathrm{H}$ & -2.49318 & -3.61661 & 5.21311 \\
\hline $\mathrm{C}$ & 6.63000 & 3.70599 & -2.20090 & $\mathrm{H}$ & -2.37534 & -4.86310 & 3.93775 \\
\hline $\mathrm{H}$ & 7.44369 & 4.19483 & -2.72205 & $\mathrm{C}$ & -3.32888 & -3.03492 & 3.33040 \\
\hline $\mathrm{C}$ & 5.46012 & 4.38787 & -1.98142 & $\mathrm{H}$ & -3.17009 & -3.17392 & 2.25296 \\
\hline $\mathrm{H}$ & 5.35201 & 5.40804 & -2.33800 & $\mathrm{H}$ & -4.32822 & -3.43130 & 3.57181 \\
\hline $\mathrm{C}$ & 4.37731 & 3.78199 & -1.30445 & $\mathrm{C}$ & -4.25612 & -0.87777 & 3.10638 \\
\hline $\mathrm{C}$ & 3.13645 & 4.45388 & -1.13252 & $\mathrm{H}$ & -5.24106 & -1.33662 & 3.27985 \\
\hline $\mathrm{H}$ & 2.98877 & 5.44854 & -1.54362 & $\mathrm{H}$ & -4.10632 & -0.77236 & 2.02344 \\
\hline $\mathrm{C}$ & 2.11409 & 3.82487 & -0.48222 & $\mathrm{C}$ & -4.20335 & 0.47227 & 3.76962 \\
\hline $\mathrm{C}$ & 2.26689 & 2.52766 & 0.07176 & $\mathrm{H}$ & -5.04437 & 1.08370 & 3.42570 \\
\hline $\mathrm{H}$ & 1.44256 & 2.05340 & 0.59748 & $\mathrm{H}$ & -4.25491 & 0.35284 & 4.86275 \\
\hline $\mathrm{C}$ & 3.44752 & 1.86324 & -0.10108 & $\mathrm{C}$ & -2.90718 & 2.42474 & 3.87263 \\
\hline $\mathrm{H}$ & 3.56659 & 0.86591 & 0.30967 & $\mathrm{H}$ & -2.95423 & 2.43573 & 4.97243 \\
\hline $\mathrm{C}$ & 4.52817 & 2.44991 & -0.82451 & $\mathrm{H}$ & -3.75568 & 2.99975 & 3.47316 \\
\hline $\mathrm{C}$ & -1.63706 & 3.97210 & -1.73759 & $\mathrm{C}$ & -1.62157 & 3.04342 & 3.39155 \\
\hline $\mathrm{H}$ & -1.36524 & 4.85896 & -2.31392 & $\mathrm{H}$ & -1.59165 & 3.05502 & 2.29674 \\
\hline $\mathrm{H}$ & -1.91909 & 3.17996 & -2.43995 & $\mathrm{H}$ & -1.56788 & 4.08246 & 3.75217 \\
\hline $\mathrm{C}$ & -2.82404 & 4.28293 & -0.83083 & $\mathrm{C}$ & 0.69396 & 2.83577 & 3.49761 \\
\hline $\mathrm{H}$ & -3.66933 & 4.60069 & -1.45754 & $\mathrm{H}$ & 0.79732 & 3.87322 & 3.85366 \\
\hline $\mathrm{H}$ & -2.58237 & 5.09812 & -0.14193 & $\mathrm{H}$ & 0.75438 & 2.86039 & 2.40709 \\
\hline $\mathrm{C}$ & 8.41981 & 0.41185 & 1.76196 & $\mathrm{C}$ & 1.81338 & 2.01739 & 4.08357 \\
\hline $\mathrm{H}$ & 9.15818 & -0.27270 & 1.32870 & $\mathrm{H}$ & 2.77550 & 2.50749 & 3.87347 \\
\hline $\mathrm{H}$ & 7.95203 & -0.06418 & 2.63230 & $\mathrm{H}$ & 1.68696 & 1.94422 & 5.17363 \\
\hline $\mathrm{C}$ & 8.91727 & 2.19504 & -2.75330 & $\mathrm{H}$ & 8.91929 & 1.32612 & 2.08047 \\
\hline $\mathrm{H}$ & 9.35104 & 3.05083 & -2.22271 & $\mathrm{H}$ & 9.67299 & 1.41752 & -2.85913 \\
\hline $\mathrm{H}$ & 8.58751 & 2.51518 & -3.74849 & $\mathrm{H}$ & -6.33802 & -3.25165 & -5.01705 \\
\hline $\mathrm{O}$ & -0.60102 & 1.51437 & 1.00791 & $\mathrm{H}$ & -7.88258 & 3.92773 & -3.15748 \\
\hline $\mathrm{O}$ & -2.07713 & 0.49593 & -0.33654 & $\mathrm{H}$ & 1.15942 & -0.74594 & 1.06785 \\
\hline $\mathrm{N}$ & -0.74221 & -0.51735 & 2.79572 & $\mathrm{H}$ & 0.24448 & -1.08502 & -0.38239 \\
\hline
\end{tabular}




$\begin{array}{lrrr}\mathrm{C} & 0.59670 & -2.80939 & 0.78742 \\ \mathrm{C} & 1.91992 & -3.24545 & 0.65635 \\ \mathrm{C} & -0.41387 & -3.76902 & 0.88063 \\ \mathrm{C} & 2.23035 & -4.60233 & 0.64830 \\ \mathrm{H} & 2.71232 & -2.50937 & 0.53894 \\ \mathrm{C} & -0.10583 & -5.12839 & 0.87334 \\ \mathrm{H} & -1.45216 & -3.46333 & 0.94844 \\ \mathrm{C} & 1.21588 & -5.55007 & 0.76279 \\ \mathrm{H} & 3.26225 & -4.92272 & 0.54406 \\ \mathrm{H} & -0.91048 & -5.85452 & 0.92902 \\ \mathrm{H} & 1.45344 & -6.60815 & 0.73876\end{array}$

(S)-2• L-phenylalanine $\Delta \mathrm{G}: 4.5 \mathrm{kcal} / \mathrm{mol}$

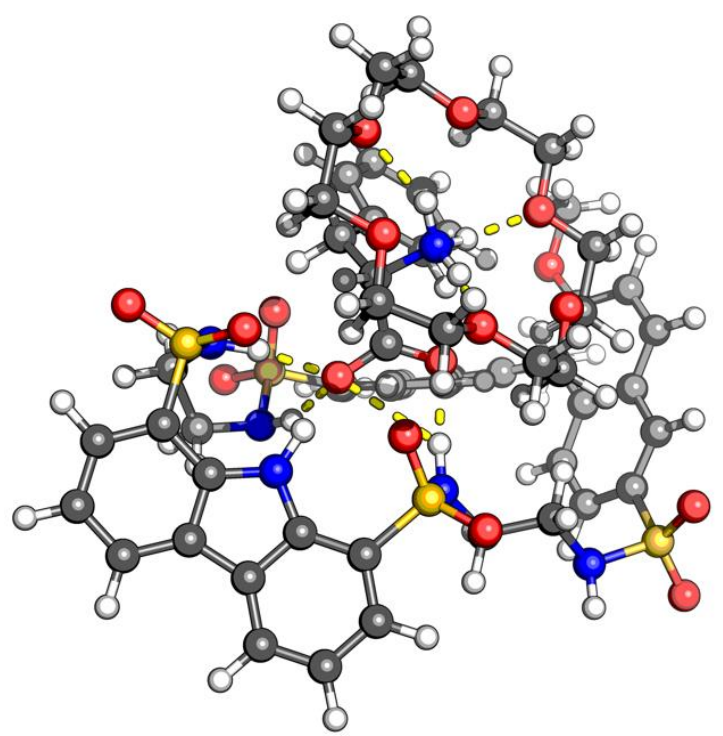

$\begin{array}{lrrr}\mathrm{S} & -2.26737 & 3.11808 & -1.16031 \\ \mathrm{~S} & 3.33124 & 5.27630 & -1.74497 \\ \mathrm{~S} & -0.66221 & -1.41292 & 3.81800 \\ \mathrm{~S} & -5.09087 & -1.63345 & 1.16856 \\ \mathrm{~N} & -4.35007 & 1.49126 & 0.69962 \\ \mathrm{H} & -3.73646 & 0.87719 & 0.16543 \\ \mathrm{~N} & -0.92477 & 2.85184 & -0.27004 \\ \mathrm{H} & -0.58652 & 1.87281 & -0.33681 \\ \mathrm{~N} & 1.85970 & 5.26683 & -0.96059 \\ \mathrm{H} & 1.45799 & 6.20054 & -1.00977 \\ \mathrm{~N} & -1.73603 & -0.16684 & 3.53999 \\ \mathrm{H} & -1.71110 & 0.08378 & 2.54373 \\ \mathrm{~N} & -3.69637 & -1.79660 & 1.99838 \\ \mathrm{H} & -2.91799 & -1.32949 & 1.50707 \\ \mathrm{O} & -2.02304 & 4.17785 & -2.13670 \\ \mathrm{O} & -2.73518 & 1.80640 & -1.60170 \\ \mathrm{O} & 3.20349 & 4.92804 & -3.15545 \\ \mathrm{O} & 3.95919 & 6.53009 & -1.35871 \\ \mathrm{O} & -0.84138 & -2.47364 & 2.82465 \\ \mathrm{O} & -0.76779 & -1.75379 & 5.23203 \\ \mathrm{O} & -4.68303 & -1.36098 & -0.21321 \\ \mathrm{O} & -5.97539 & -2.74454 & 1.47635\end{array}$

\begin{tabular}{|c|c|c|c|}
\hline $\mathrm{O}$ & 6.00049 & -1.91666 & 2799 \\
\hline $\mathrm{O}$ & 7.19343 & -0.07301 & 2.78838 \\
\hline $\mathrm{C}$ & -3.64711 & 5.11221 & 0.11840 \\
\hline $\mathrm{H}$ & -3.03981 & 5.77626 & -0.48811 \\
\hline $\mathrm{C}$ & -4.61152 & 5.62210 & 0.99610 \\
\hline $\mathrm{C}$ & -5.43470 & 4.76287 & 1.71057 \\
\hline $\mathrm{H}$ & -6.19785 & 5.15775 & 2.37444 \\
\hline $\mathrm{C}$ & -5.28725 & 3.38459 & 1.55441 \\
\hline $\mathrm{C}$ & -5.99860 & 2.24165 & 2.08222 \\
\hline $\mathrm{C}$ & -7.08259 & 2.09869 & 2.94910 \\
\hline $\mathrm{H}$ & -7.54623 & 2.97515 & 3.39181 \\
\hline $\mathrm{C}$ & -7.56440 & 0.82847 & 3.23275 \\
\hline $\mathrm{C}$ & -6.96834 & -0.30132 & 2.65820 \\
\hline $\mathrm{H}$ & -7.34657 & -1.29849 & 2.85892 \\
\hline $\mathrm{C}$ & -5.88347 & -0.17695 & 1.80040 \\
\hline $\mathrm{C}$ & -5.38795 & 1.09988 & 1.51026 \\
\hline $\mathrm{C}$ & -4.28861 & 2.86505 & 0.69594 \\
\hline $\mathrm{C}$ & -3.47415 & 3.74262 & -0.03003 \\
\hline $\mathrm{C}$ & 0.02788 & 3.93169 & -0.07098 \\
\hline $\mathrm{H}$ & 0.63962 & 3.68249 & 0.80079 \\
\hline $\mathrm{H}$ & -0.52356 & 4.84706 & 0.17583 \\
\hline $\mathrm{C}$ & 0.93826 & 4.17220 & -1.27696 \\
\hline $\mathrm{H}$ & 1.53482 & 3.26880 & -1.45216 \\
\hline $\mathrm{H}$ & 0.34871 & 4.36720 & -2.17725 \\
\hline $\mathrm{C}$ & 4.07416 & 3.88162 & -0.93757 \\
\hline $\mathrm{C}$ & 4.63881 & 2.90434 & -1.70793 \\
\hline $\mathrm{H}$ & 4.68171 & 3.02254 & -2.78729 \\
\hline $\mathrm{C}$ & 5.10706 & 1.71347 & -1.09480 \\
\hline $\mathrm{C}$ & 5.66505 & 0.66357 & -1.85691 \\
\hline $\mathrm{H}$ & 5.81136 & 0.80753 & -2.92430 \\
\hline $\mathrm{C}$ & 6.00187 & -0.53034 & -1.27007 \\
\hline $\mathrm{H}$ & 6.42023 & -1.32503 & -1.87582 \\
\hline $\mathrm{C}$ & 5.76863 & -0.72992 & 0.11291 \\
\hline $\mathrm{C}$ & 5.24851 & 0.28688 & 0.90427 \\
\hline $\mathrm{C}$ & 4.94340 & 1.53828 & 0.30954 \\
\hline $\mathrm{C}$ & 4.41425 & 2.61899 & 1.07755 \\
\hline $\mathrm{H}$ & 4.33017 & 2.50231 & 2.15277 \\
\hline $\mathrm{C}$ & 3.99226 & 3.76924 & 0.47391 \\
\hline $\mathrm{H}$ & 3.55930 & 4.58249 & 1.04643 \\
\hline $\mathrm{C}$ & 4.91402 & -0.00445 & 2.32429 \\
\hline $\mathrm{C}$ & 5.92655 & -0.23306 & 3.24285 \\
\hline $\mathrm{C}$ & 5.62723 & -0.61420 & 4.57425 \\
\hline $\mathrm{H}$ & 6.42263 & -0.78253 & 5.28934 \\
\hline $\mathrm{C}$ & 4.32268 & -0.79713 & 4.95463 \\
\hline $\mathrm{H}$ & 4.09252 & -1.11769 & 5.96654 \\
\hline $\mathrm{C}$ & 3.25883 & -0.58801 & 4.04747 \\
\hline $\mathrm{C}$ & 1.91588 & -0.87595 & 4.40794 \\
\hline $\mathrm{H}$ & 1.68351 & -1.28026 & 5.38929 \\
\hline $\mathrm{C}$ & 0.92109 & -0.69513 & 3.48875 \\
\hline $\mathrm{C}$ & 1.18075 & -0.17672 & 2.19838 \\
\hline $\mathrm{H}$ & 0.37221 & -0.01359 & 1.49310 \\
\hline $\mathrm{C}$ & 2.46909 & 0.08557 & 1.82983 \\
\hline $\mathrm{H}$ & 2.66268 & 0.44120 & 0.82318 \\
\hline $\mathrm{C}$ & 3.55574 & -0.15321 & 2.72299 \\
\hline $\mathrm{C}$ & -3.09952 & -0.46699 & 4.01603 \\
\hline
\end{tabular}




$\begin{array}{lrrrrrrr}\mathrm{H} & -3.06610 & -0.52162 & 5.10691 & \mathrm{C} & 0.22362 & 1.51811 & -3.59326 \\ \mathrm{H} & -3.71441 & 0.39226 & 3.73159 & \mathrm{H} & 0.82458 & 2.35663 & -3.98230 \\ \mathrm{C} & -3.70695 & -1.76343 & 3.46076 & \mathrm{H} & 0.03296 & 1.67713 & -2.52585 \\ \mathrm{H} & -4.73977 & -1.85703 & 3.81303 & \mathrm{C} & -1.09462 & 1.45319 & -4.32154 \\ \mathrm{H} & -3.15678 & -2.63178 & 3.83200 & \mathrm{H} & -1.63440 & 2.39474 & -4.14484 \\ \mathrm{C} & 6.38093 & -3.02010 & -0.06628 & \mathrm{H} & -0.93963 & 1.32185 & -5.40285 \\ \mathrm{H} & 7.34501 & -2.85150 & -0.55943 & \mathrm{H} & 6.47318 & -3.86272 & 0.61847 \\ \mathrm{H} & 5.61536 & -3.24788 & -0.81962 & \mathrm{H} & 9.17295 & -0.18024 & 3.09315 \\ \mathrm{C} & 8.26247 & -0.35090 & 3.66669 & \mathrm{H} & -4.72624 & 6.69526 & 1.09731 \\ \mathrm{H} & 8.23883 & -1.39180 & 4.00963 & \mathrm{H} & -8.40965 & 0.70369 & 3.89985 \\ \mathrm{H} & 8.25513 & 0.31790 & 4.53515 & \mathrm{C} & -1.15951 & -3.04270 & -0.23436 \\ \mathrm{O} & -0.15809 & 0.21121 & -0.81889 & \mathrm{H} & -2.51061 & -1.77454 & -1.28059 \\ \mathrm{O} & -1.82510 & -0.20446 & 0.61518 & \mathrm{H} & -1.69109 & -2.90522 & 0.71357 \\ \mathrm{~N} & -0.76862 & -1.87347 & -2.41673 & \mathrm{H} & -1.63109 & -3.89501 & -0.73627 \\ \mathrm{H} & -1.12568 & -2.69733 & -2.92084 & \mathrm{C} & 0.27918 & -3.39100 & 0.08923 \\ \mathrm{H} & 0.25719 & -1.94927 & -2.36544 & \mathrm{C} & 0.53888 & -4.66562 & 0.61405 \\ \mathrm{H} & -0.99205 & -1.02690 & -2.97357 & \mathrm{C} & 1.35205 & -2.51309 & -0.05586 \\ \mathrm{C} & -1.43507 & -1.80141 & -1.08678 & \mathrm{C} & 1.82366 & -5.05041 & 0.97463 \\ \mathrm{C} & -1.10498 & -0.48054 & -0.38050 & \mathrm{H} & -0.29134 & -5.35318 & 0.76107 \\ \mathrm{O} & -1.83173 & 0.36645 & -3.80321 & \mathrm{C} & 2.64660 & -2.89480 & 0.30350 \\ \mathrm{O} & -3.40654 & -1.90354 & -3.63597 & \mathrm{H} & 1.19448 & -1.51140 & -0.44055 \\ \mathrm{O} & -2.25461 & -4.36049 & -3.03768 & \mathrm{C} & 2.88931 & -4.16092 & 0.81878 \\ \mathrm{O} & 0.53472 & -4.44889 & -3.28238 & \mathrm{H} & 1.99330 & -6.03837 & 1.39148 \\ \mathrm{O} & 2.08880 & -2.14454 & -2.98695 & \mathrm{H} & 3.45978 & -2.17945 & 0.19955 \\ \mathrm{O} & 0.90164 & 0.29198 & -3.77965 & \mathrm{H} & 3.89311 & -4.44786 & 1.11740 \\ \mathrm{C} & -3.19421 & 0.39610 & -4.16717 & & & & \end{array}$

(S)-2• D-phenylalanine

(binaphthyl gap occupied by phenyl group, alternative)

$\Delta \mathrm{G}: 10.3 \mathrm{kcal} / \mathrm{mol}$

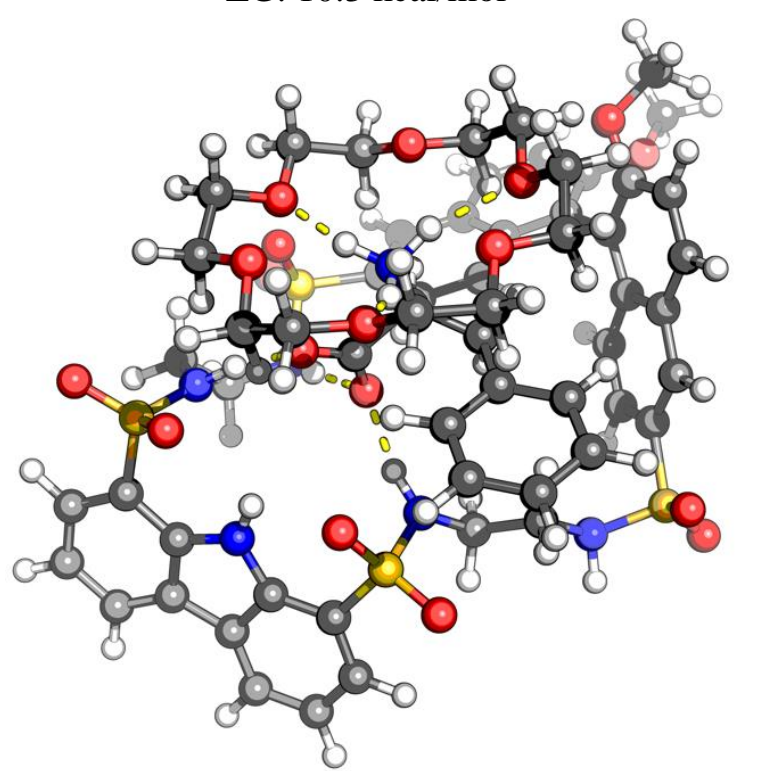

$\begin{array}{lrrr}\mathrm{S} & 3.11475 & 3.16226 & -0.12338 \\ \mathrm{~S} & -2.40670 & 5.22531 & -1.78487 \\ \mathrm{~S} & 0.61333 & -3.54736 & -2.39588 \\ \mathrm{~S} & 5.25666 & -2.28428 & 0.42025 \\ \mathrm{~N} & 5.04767 & 0.66522 & -0.72632 \\ \mathrm{H} & 4.48562 & 0.53008 & 0.11062\end{array}$




\begin{tabular}{|c|c|c|c|c|c|c|c|}
\hline $\mathrm{N}$ & 1.78805 & 2.50297 & -0.79505 & $\mathrm{C}$ & -4.87594 & -1.22401 & -2.18387 \\
\hline $\mathrm{H}$ & 1.69533 & 1.48004 & -0.71670 & $\mathrm{C}$ & -5.92343 & -1.89475 & -2.79674 \\
\hline $\mathrm{N}$ & -0.89166 & 4.67712 & -2.20135 & $\mathrm{C}$ & -5.67846 & -3.03070 & -3.60869 \\
\hline $\mathrm{H}$ & -0.42537 & 5.41365 & -2.72751 & $\mathrm{H}$ & -6.50038 & -3.54070 & -4.09549 \\
\hline $\mathrm{N}$ & 1.70809 & -2.31086 & -2.58792 & $\mathrm{C}$ & -4.40064 & -3.50472 & -3.77142 \\
\hline $\mathrm{H}$ & 1.60439 & -1.59502 & -1.85349 & $\mathrm{H}$ & -4.22392 & -4.38632 & -4.38078 \\
\hline $\mathrm{N}$ & 3.83944 & -2.39250 & -0.38943 & $\mathrm{C}$ & -3.30128 & -2.87019 & -3.14883 \\
\hline $\mathrm{H}$ & 3.04374 & -2.02502 & 0.15144 & $\mathrm{C}$ & -1.97902 & -3.39360 & -3.24067 \\
\hline $\mathrm{O}$ & 2.85400 & 4.58216 & 0.06745 & $\mathrm{H}$ & -1.78897 & -4.31340 & -3.78746 \\
\hline $\mathrm{O}$ & 3.48841 & 2.28402 & 0.98302 & $\mathrm{C}$ & -0.95623 & -2.74422 & -2.60575 \\
\hline $\mathrm{O}$ & -2.43259 & 5.80931 & -0.44910 & $\mathrm{C}$ & -1.17496 & -1.54862 & -1.88770 \\
\hline $\mathrm{O}$ & -2.85878 & 5.99889 & -2.93101 & $\mathrm{H}$ & -0.34635 & -1.01319 & -1.43590 \\
\hline $\mathrm{O}$ & 0.62501 & -4.03935 & -1.01232 & $\mathrm{C}$ & -2.43981 & -1.06159 & -1.75278 \\
\hline $\mathrm{O}$ & 0.82689 & -4.50711 & -3.47123 & $\mathrm{H}$ & -2.59550 & -0.17043 & -1.15907 \\
\hline $\mathrm{O}$ & 5.01786 & -1.33753 & 1.50567 & $\mathrm{C}$ & -3.55011 & -1.70737 & -2.36259 \\
\hline $\mathrm{O}$ & 5.82444 & -3.59813 & 0.69202 & $\mathrm{C}$ & 3.10008 & -2.77560 & -2.71600 \\
\hline $\mathrm{O}$ & -6.28398 & -1.61271 & 0.13085 & $\mathrm{H}$ & 3.12900 & -3.50334 & -3.53110 \\
\hline $\mathrm{O}$ & -7.16965 & -1.40870 & -2.56870 & $\mathrm{H}$ & 3.69075 & -1.90206 & -3.00564 \\
\hline $\mathrm{C}$ & 4.74399 & 4.10597 & -2.13373 & $\mathrm{C}$ & 3.69337 & -3.38874 & -1.44519 \\
\hline $\mathrm{H}$ & 4.20115 & 5.03625 & -2.00045 & $\mathrm{H}$ & 4.69109 & -3.77265 & -1.68335 \\
\hline $\mathrm{C}$ & 5.75882 & 3.99287 & -3.09273 & $\mathrm{H}$ & 3.09193 & -4.23597 & -1.10199 \\
\hline $\mathrm{C}$ & 6.47901 & 2.81278 & -3.22272 & $\mathrm{C}$ & -7.63124 & -1.73790 & 0.55620 \\
\hline $\mathrm{H}$ & 7.27053 & 2.73055 & -3.96155 & $\mathrm{H}$ & -8.28408 & -1.09947 & -0.04752 \\
\hline $\mathrm{C}$ & 6.18703 & 1.73490 & -2.38602 & $\mathrm{H}$ & -7.75079 & -1.49042 & 1.61776 \\
\hline $\mathrm{C}$ & 6.74343 & 0.40738 & -2.22769 & $\mathrm{C}$ & -8.26615 & -2.05585 & -3.18090 \\
\hline $\mathrm{C}$ & 7.77674 & -0.29725 & -2.84964 & $\mathrm{H}$ & -8.35782 & -3.09510 & -2.84355 \\
\hline $\mathrm{H}$ & 8.34710 & 0.16338 & -3.65076 & $\mathrm{H}$ & -8.18623 & -2.03406 & -4.27344 \\
\hline $\mathrm{C}$ & 8.06953 & -1.58885 & -2.43267 & $\mathrm{O}$ & 1.13664 & -0.19009 & -0.55042 \\
\hline $\mathrm{C}$ & 7.32834 & -2.19581 & -1.40819 & $\mathrm{O}$ & 1.92629 & -1.08289 & 1.34646 \\
\hline $\mathrm{H}$ & 7.54201 & -3.20831 & -1.08045 & $\mathrm{~N}$ & -0.34744 & -0.93153 & 2.68248 \\
\hline $\mathrm{C}$ & 6.29457 & -1.51074 & -0.78857 & $\mathrm{H}$ & -1.30611 & -1.00220 & 3.05105 \\
\hline $\mathrm{C}$ & 6.00680 & -0.20223 & -1.18796 & $\mathrm{H}$ & 0.18448 & -0.28083 & 3.28350 \\
\hline $\mathrm{C}$ & 5.15271 & 1.84489 & -1.42559 & $\mathrm{H}$ & 0.12152 & -1.85304 & 2.75185 \\
\hline $\mathrm{C}$ & 4.43200 & 3.03798 & -1.30326 & $\mathrm{C}$ & -0.38895 & -0.53009 & 1.25344 \\
\hline $\mathrm{C}$ & 1.01654 & 3.21576 & -1.79640 & $\mathrm{C}$ & 1.03177 & -0.59401 & 0.64726 \\
\hline $\mathrm{H}$ & 0.56737 & 2.47509 & -2.46447 & $\mathrm{O}$ & 0.46927 & -3.65083 & 2.13940 \\
\hline $\mathrm{H}$ & 1.67146 & 3.85129 & -2.40889 & $\mathrm{O}$ & -2.28291 & -3.04669 & 1.99444 \\
\hline $\mathrm{C}$ & -0.08439 & 4.05200 & -1.14719 & $\mathrm{O}$ & -3.33536 & -0.69226 & 3.04330 \\
\hline $\mathrm{H}$ & -0.73777 & 3.38580 & -0.57553 & $\mathrm{O}$ & -1.67500 & 0.66296 & 4.83040 \\
\hline $\mathrm{H}$ & 0.34153 & 4.77482 & -0.44296 & $\mathrm{O}$ & 1.11609 & 0.36478 & 4.78527 \\
\hline $\mathrm{C}$ & -3.29165 & 3.68513 & -1.68452 & $\mathrm{O}$ & 1.99666 & -2.24694 & 4.01878 \\
\hline $\mathrm{C}$ & -4.03977 & 3.43686 & -0.56770 & $\mathrm{C}$ & -0.50063 & -4.59493 & 1.73554 \\
\hline $\mathrm{H}$ & -4.08886 & 4.18032 & 0.22306 & $\mathrm{H}$ & -0.88000 & -5.14060 & 2.61397 \\
\hline $\mathrm{C}$ & -4.70866 & 2.19355 & -0.42872 & $\mathrm{H}$ & -0.05658 & -5.30905 & 1.03011 \\
\hline $\mathrm{C}$ & -5.45749 & 1.89563 & 0.73701 & $\mathrm{C}$ & -1.64604 & -3.89195 & 1.05368 \\
\hline $\mathrm{H}$ & -5.56318 & 2.65796 & 1.50397 & $\mathrm{H}$ & -1.27754 & -3.32159 & 0.19268 \\
\hline $\mathrm{C}$ & -6.03161 & 0.66388 & 0.89620 & $\mathrm{H}$ & -2.35526 & -4.64736 & 0.68098 \\
\hline $\mathrm{H}$ & -6.60409 & 0.43363 & 1.78912 & $\mathrm{C}$ & -3.48582 & -2.49472 & 1.51188 \\
\hline $\mathrm{C}$ & -5.84130 & -0.33857 & -0.08758 & $\mathrm{H}$ & -4.15794 & -3.27667 & 1.12799 \\
\hline $\mathrm{C}$ & -5.13468 & -0.09106 & -1.25082 & $\mathrm{H}$ & -3.30253 & -1.78320 & 0.68920 \\
\hline $\mathrm{C}$ & -4.58494 & 1.21272 & -1.45363 & $\mathrm{C}$ & -4.14668 & -1.78788 & 2.66559 \\
\hline $\mathrm{C}$ & -3.86330 & 1.55366 & -2.63571 & $\mathrm{H}$ & -5.14382 & -1.43777 & 2.36516 \\
\hline $\mathrm{H}$ & -3.80126 & 0.82643 & -3.43832 & $\mathrm{H}$ & -4.25158 & -2.48558 & 3.50942 \\
\hline $\mathrm{C}$ & -3.22343 & 2.75801 & -2.75215 & $\mathrm{C}$ & -3.84407 & -0.02083 & 4.17431 \\
\hline $\mathrm{H}$ & -2.64667 & 3.00681 & -3.63656 & $\mathrm{H}$ & -3.88232 & -0.70545 & 5.03444 \\
\hline
\end{tabular}




$\begin{array}{lrrr}\mathrm{H} & -4.86476 & 0.34112 & 3.97184 \\ \mathrm{C} & -2.95140 & 1.15132 & 4.49112 \\ \mathrm{H} & -2.89203 & 1.82656 & 3.62586 \\ \mathrm{H} & -3.38683 & 1.71231 & 5.33370 \\ \mathrm{C} & -0.81547 & 1.69553 & 5.27594 \\ \mathrm{H} & -1.29253 & 2.25297 & 6.09790 \\ \mathrm{H} & -0.59967 & 2.39836 & 4.46276 \\ \mathrm{C} & 0.45359 & 1.07518 & 5.80691 \\ \mathrm{H} & 1.10248 & 1.87383 & 6.19848 \\ \mathrm{H} & 0.20988 & 0.39274 & 6.63532 \\ \mathrm{C} & 2.30736 & -0.24691 & 5.25486 \\ \mathrm{H} & 2.08374 & -0.83313 & 6.15833 \\ \mathrm{H} & 3.04209 & 0.52955 & 5.51390 \\ \mathrm{C} & 2.88102 & -1.15531 & 4.19726 \\ \mathrm{H} & 3.03309 & -0.62688 & 3.24851 \\ \mathrm{H} & 3.86153 & -1.51406 & 4.54649 \\ \mathrm{C} & 2.57430 & -3.24955 & 3.20566 \\ \mathrm{H} & 3.39359 & -3.75261 & 3.74311 \\ \mathrm{H} & 2.98006 & -2.80984 & 2.29137 \\ \mathrm{C} & 1.51336 & -4.26691 & 2.87034 \\ \mathrm{H} & 1.96604 & -5.07096 & 2.27151 \\ \mathrm{H} & 1.10546 & -4.70830 & 3.79314 \\ \mathrm{H} & -7.90221 & -2.78403 & 0.40809 \\ \mathrm{H} & -9.15120 & -1.49764 & -2.87659 \\ \mathrm{H} & 5.98783 & 4.84072 & -3.72829 \\ \mathrm{H} & 8.87371 & -2.14065 & -2.90606 \\ \mathrm{C} & -1.13318 & 0.78127 & 1.02220 \\ \mathrm{H} & -0.95490 & -1.32178 & 0.75110 \\ \mathrm{H} & -1.05175 & 0.97422 & -0.05796 \\ \mathrm{H} & -2.19849 & 0.63465 & 1.24685 \\ \mathrm{C} & -0.62998 & 2.00537 & 1.75448 \\ \mathrm{C} & -1.50532 & 3.08775 & 1.90843 \\ \mathrm{C} & 0.69267 & 2.15522 & 2.17081 \\ \mathrm{C} & -1.07289 & 4.29817 & 2.43908 \\ \mathrm{H} & -2.53348 & 2.97976 & 1.56896 \\ \mathrm{C} & 1.13026 & 3.36479 & 2.71281 \\ \mathrm{H} & 1.41743 & 1.35415 & 2.05775 \\ \mathrm{C} & 0.25527 & 4.43854 & 2.84225 \\ \mathrm{H} & -1.76181 & 5.13370 & 2.50816 \\ \mathrm{H} & 2.17386 & 3.46399 & 2.99227 \\ \mathrm{H} & 0.60903 & 5.38507 & 3.23752 \\ & & & \end{array}$

(S)-2• D-phenylalanine (alternative gauche conformations for both ethylenediamine) $12.1 \mathrm{kcal} / \mathrm{mol}$

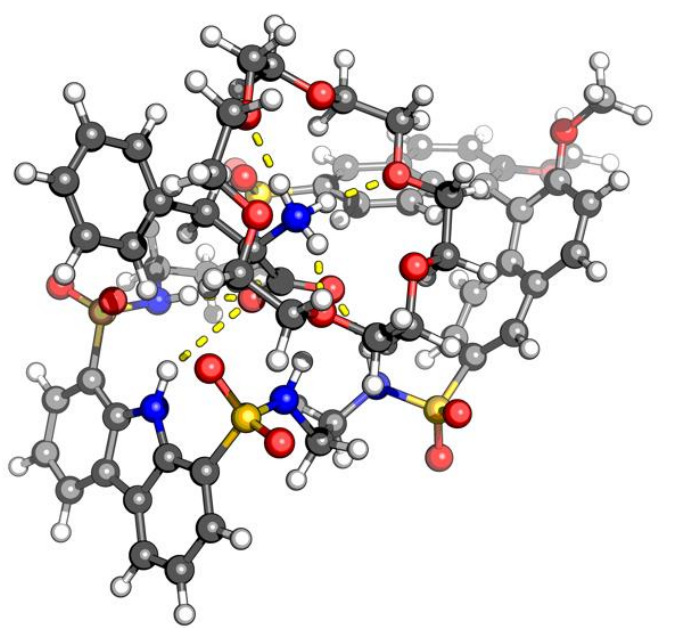

$\begin{array}{rrrr}\text { S } & 3.64493 & -1.73323 & -2.20660 \\ \mathrm{~S} & -1.47576 & -4.21413 & -1.46226 \\ \mathrm{~S} & -1.01715 & 1.43644 & 3.56469 \\ \mathrm{~S} & 4.22633 & 0.56547 & 3.24049 \\ \mathrm{~N} & 4.67310 & -1.52532 & 0.82055 \\ \mathrm{H} & 4.10548 & -0.72734 & 0.55556 \\ \mathrm{~N} & 2.25960 & -2.09075 & -1.38627 \\ \mathrm{H} & 1.54422 & -1.37829 & -1.55923 \\ \mathrm{~N} & -0.55821 & -3.25490 & -0.47105 \\ \mathrm{H} & -0.66139 & -2.23647 & -0.58920 \\ \mathrm{~N} & -0.27674 & -0.04379 & 3.66536 \\ \mathrm{H} & 0.07629 & -0.33383 & 2.74362 \\ \mathrm{~N} & 2.67115 & 0.09274 & 3.46955 \\ \mathrm{H} & 2.15367 & 0.12791 & 2.57990 \\ \mathrm{O} & 3.61359 & -2.13990 & -3.60914 \\ \mathrm{O} & 3.94249 & -0.33616 & -1.87840 \\ \mathrm{O} & -1.26856 & -3.95425 & -2.88970 \\ \mathrm{O} & -1.29340 & -5.57924 & -0.98319 \\ \mathrm{O} & -0.36462 & 2.28119 & 2.56190 \\ \mathrm{O} & -1.18652 & 1.92664 & 4.92712 \\ \mathrm{O} & 4.31496 & 1.09302 & 1.87865 \\ \mathrm{O} & 4.65346 & 1.33931 & 4.39513 \\ \mathrm{O} & -7.82297 & 0.55727 & -0.71577 \\ \mathrm{O} & -8.46238 & -1.05151 & 1.60601 \\ \mathrm{C} & 5.38959 & -3.84393 & -2.01175 \\ \mathrm{H} & 5.14492 & -4.01219 & -3.05559 \\ \mathrm{C} & 6.26786 & -4.68940 & -1.32443 \\ \mathrm{C} & 6.55865 & -4.46681 & 0.01661 \\ \mathrm{H} & 7.23473 & -5.13030 & 0.54767 \\ \mathrm{C} & 5.98128 & -3.38251 & 0.67681 \\ \mathrm{C} & 6.08075 & -2.85414 & 2.02137 \\ \mathrm{C} & 6.78948 & -3.23965 & 3.16062 \\ \mathrm{H} & 7.41519 & -4.12677 & 3.14116 \\ \mathrm{C} & 6.69659 & -2.47034 & 4.31175 \\ \mathrm{C} & 5.90593 & -1.31359 & 4.33455 \\ \mathrm{H} & 5.86028 & -0.68560 & 5.21827\end{array}$




\begin{tabular}{|c|c|c|c|}
\hline $\mathrm{C}$ & 5.18658 & -0.92495 & 3.21487 \\
\hline $\mathrm{C}$ & 5.26630 & -1.69873 & 2.05188 \\
\hline $\mathrm{C}$ & 5.10118 & -2.51968 & -0.01969 \\
\hline $\mathrm{C}$ & 4.80243 & -2.76510 & -1.36448 \\
\hline $\mathrm{C}$ & 1.77569 & -3.47808 & -1.39855 \\
\hline $\mathrm{H}$ & 2.64626 & -4.12608 & -1.25994 \\
\hline $\mathrm{H}$ & 1.29952 & -3.74336 & -2.35103 \\
\hline $\mathrm{C}$ & 0.81381 & -3.69385 & -0.22712 \\
\hline $\mathrm{H}$ & 0.77514 & -4.75558 & 0.02734 \\
\hline $\mathrm{H}$ & 1.17694 & -3.12996 & 0.63723 \\
\hline $\mathrm{C}$ & -3.07742 & -3.57247 & -1.05512 \\
\hline $\mathrm{C}$ & -3.89251 & -3.13236 & -2.06009 \\
\hline $\mathrm{H}$ & -3.60216 & -3.28408 & -3.09624 \\
\hline $\mathrm{C}$ & -5.04749 & -2.36815 & -1.73899 \\
\hline $\mathrm{C}$ & -5.85909 & -1.78625 & -2.74095 \\
\hline $\mathrm{H}$ & -5.68600 & -2.05261 & -3.78012 \\
\hline $\mathrm{C}$ & -6.83021 & -0.87122 & -2.41866 \\
\hline $\mathrm{H}$ & -7.43301 & -0.43381 & -3.20486 \\
\hline $\mathrm{C}$ & -6.98998 & -0.44869 & -1.07329 \\
\hline $\mathrm{C}$ & -6.23804 & -1.02165 & -0.05665 \\
\hline $\mathrm{C}$ & -5.30938 & -2.05110 & -0.37713 \\
\hline $\mathrm{C}$ & -4.53451 & -2.69661 & 0.63442 \\
\hline $\mathrm{H}$ & -4.79469 & -2.54105 & 1.67506 \\
\hline $\mathrm{C}$ & -3.43176 & -3.43046 & 0.30953 \\
\hline $\mathrm{H}$ & -2.79262 & -3.85985 & 1.07311 \\
\hline $\mathrm{C}$ & -6.23315 & -0.44361 & 1.31330 \\
\hline $\mathrm{C}$ & -7.35321 & -0.47735 & 2.12856 \\
\hline $\mathrm{C}$ & -7.30184 & 0.03827 & 3.44954 \\
\hline $\mathrm{H}$ & -8.18315 & 0.01708 & 4.07824 \\
\hline $\mathrm{C}$ & -6.12729 & 0.53803 & 3.95011 \\
\hline $\mathrm{H}$ & -6.08519 & 0.90160 & 4.97272 \\
\hline $\mathrm{C}$ & -4.95210 & 0.57245 & 3.16241 \\
\hline $\mathrm{C}$ & -3.70899 & 1.01093 & 3.69374 \\
\hline $\mathrm{H}$ & -3.63356 & 1.33317 & 4.72851 \\
\hline $\mathrm{C}$ & -2.59663 & 0.99740 & 2.89877 \\
\hline $\mathrm{C}$ & -2.65134 & 0.61563 & 1.53849 \\
\hline $\mathrm{H}$ & -1.76835 & 0.64447 & 0.90553 \\
\hline $\mathrm{C}$ & -3.84135 & 0.20024 & 1.01618 \\
\hline $\mathrm{H}$ & -3.87434 & -0.08373 & -0.02797 \\
\hline $\mathrm{C}$ & -5.01978 & 0.11477 & 1.81573 \\
\hline $\mathrm{C}$ & 0.65329 & -0.24935 & 4.78018 \\
\hline $\mathrm{H}$ & 0.13656 & 0.03037 & 5.70033 \\
\hline $\mathrm{H}$ & 0.86877 & -1.32056 & 4.80915 \\
\hline $\mathrm{C}$ & 1.95432 & 0.53574 & 4.66609 \\
\hline $\mathrm{H}$ & 2.58020 & 0.33791 & 5.53999 \\
\hline $\mathrm{H}$ & 1.74199 & 1.61228 & 4.64329 \\
\hline $\mathrm{C}$ & -8.58687 & 1.18893 & -1.72033 \\
\hline $\mathrm{H}$ & -9.27685 & 0.48655 & -2.20201 \\
\hline $\mathrm{H}$ & -7.94675 & 1.64886 & -2.48273 \\
\hline $\mathrm{C}$ & -9.62010 & -1.13485 & 2.40896 \\
\hline $\mathrm{H}$ & -9.98563 & -0.14075 & 2.69168 \\
\hline $\mathrm{H}$ & -9.44019 & -1.72645 & 3.31417 \\
\hline $\mathrm{O}$ & -0.17691 & -0.37217 & -0.68322 \\
\hline $\mathrm{O}$ & 1.14203 & -0.23933 & 1.12556 \\
\hline $\mathrm{N}$ & 0.44725 & 1.96295 & -1.65074 \\
\hline
\end{tabular}

\begin{tabular}{|c|c|c|c|}
\hline $\mathrm{H}$ & 0.66285 & 2.94467 & -1.88318 \\
\hline $\mathrm{H}$ & -0.54386 & 1.88815 & -1.37430 \\
\hline $\mathrm{H}$ & 0.54034 & 1.40164 & -2.51326 \\
\hline $\mathrm{C}$ & 1.36789 & 1.42281 & -0.59607 \\
\hline $\mathrm{C}$ & 0.70442 & 0.17260 & 0.03031 \\
\hline $\mathrm{O}$ & 1.55140 & 0.25902 & -3.71261 \\
\hline $\mathrm{O}$ & 2.21764 & 3.02795 & -3.70948 \\
\hline $\mathrm{O}$ & 0.93603 & 4.85702 & -2.06530 \\
\hline $\mathrm{O}$ & -1.51894 & 4.25809 & -1.03326 \\
\hline $\mathrm{O}$ & -2.55605 & 1.71071 & -1.41994 \\
\hline $\mathrm{O}$ & -1.21379 & 0.09686 & -3.42464 \\
\hline $\mathrm{C}$ & 2.59799 & 0.81041 & -4.50001 \\
\hline $\mathrm{H}$ & 2.18638 & 1.12522 & -5.47010 \\
\hline $\mathrm{H}$ & 3.37101 & 0.05014 & -4.66651 \\
\hline $\mathrm{C}$ & 3.20024 & 2.01203 & -3.82102 \\
\hline $\mathrm{H}$ & 3.60352 & 1.74808 & -2.83742 \\
\hline $\mathrm{H}$ & 4.03650 & 2.36262 & -4.44668 \\
\hline $\mathrm{C}$ & 2.80396 & 4.27876 & -3.41938 \\
\hline $\mathrm{H}$ & 3.41314 & 4.62193 & -4.27156 \\
\hline $\mathrm{H}$ & 3.45302 & 4.21154 & -2.53944 \\
\hline $\mathrm{C}$ & 1.71193 & 5.28637 & -3.16506 \\
\hline $\mathrm{H}$ & 2.17947 & 6.25742 & -2.94213 \\
\hline $\mathrm{H}$ & 1.06909 & 5.40033 & -4.05051 \\
\hline $\mathrm{C}$ & 0.09826 & 5.87345 & -1.56713 \\
\hline $\mathrm{H}$ & -0.54516 & 6.26160 & -2.37105 \\
\hline $\mathrm{H}$ & 0.70386 & 6.70472 & -1.17234 \\
\hline $\mathrm{C}$ & -0.76638 & 5.30177 & -0.47010 \\
\hline $\mathrm{H}$ & -0.15333 & 4.93567 & 0.36665 \\
\hline $\mathrm{H}$ & -1.42406 & 6.09516 & -0.08032 \\
\hline $\mathrm{C}$ & -2.46345 & 3.70365 & -0.14122 \\
\hline $\mathrm{H}$ & -3.08203 & 4.49523 & 0.30949 \\
\hline $\mathrm{H}$ & -1.96225 & 3.15524 & 0.67183 \\
\hline $\mathrm{C}$ & -3.34081 & 2.79176 & -0.96049 \\
\hline $\mathrm{H}$ & -4.18560 & 2.42120 & -0.36168 \\
\hline $\mathrm{H}$ & -3.73384 & 3.36012 & -1.81639 \\
\hline $\mathrm{C}$ & -3.20425 & 0.98450 & -2.44505 \\
\hline $\mathrm{H}$ & -3.31379 & 1.61380 & -3.34095 \\
\hline $\mathrm{H}$ & -4.21104 & 0.67841 & -2.11246 \\
\hline $\mathrm{C}$ & -2.41016 & -0.25282 & -2.77072 \\
\hline $\mathrm{H}$ & -2.19590 & -0.79968 & -1.84051 \\
\hline $\mathrm{H}$ & -3.02126 & -0.89938 & -3.42121 \\
\hline $\mathrm{C}$ & -0.44369 & -1.05799 & -3.69029 \\
\hline $\mathrm{H}$ & -1.02148 & -1.78839 & -4.27573 \\
\hline $\mathrm{H}$ & -0.17373 & -1.55310 & -2.74932 \\
\hline $\mathrm{C}$ & 0.77955 & -0.66037 & -4.47073 \\
\hline $\mathrm{H}$ & 1.38274 & -1.54852 & -4.70425 \\
\hline $\mathrm{H}$ & 0.46837 & -0.18182 & -5.41069 \\
\hline $\mathrm{H}$ & -9.15931 & 1.96644 & -1.21591 \\
\hline $\mathrm{H}$ & -10.37192 & -1.63357 & 1.79837 \\
\hline $\mathrm{H}$ & 6.71808 & -5.52661 & -1.84505 \\
\hline $\mathrm{H}$ & 7.25118 & -2.75300 & 5.19923 \\
\hline $\mathrm{C}$ & 1.79316 & 2.49322 & 0.40662 \\
\hline $\mathrm{H}$ & 2.24621 & 1.03989 & -1.13166 \\
\hline $\mathrm{H}$ & 0.92778 & 3.11148 & 0.66575 \\
\hline $\mathrm{H}$ & 2.06705 & 1.96741 & 1.32517 \\
\hline
\end{tabular}




$\begin{array}{lrrr}\mathrm{C} & 2.97079 & 3.34709 & -0.01128 \\ \mathrm{C} & 2.93687 & 4.73525 & 0.13588 \\ \mathrm{C} & 4.15491 & 2.76145 & -0.47111 \\ \mathrm{C} & 4.03780 & 5.52408 & -0.18829 \\ \mathrm{H} & 2.03501 & 5.20544 & 0.51838 \\ \mathrm{C} & 5.26165 & 3.54361 & -0.79158 \\ \mathrm{H} & 4.22753 & 1.68094 & -0.55935 \\ \mathrm{C} & 5.20635 & 4.92901 & -0.65818 \\ \mathrm{H} & 3.98558 & 6.60173 & -0.06298 \\ \mathrm{H} & 6.17146 & 3.06422 & -1.13912 \\ \mathrm{H} & 6.06973 & 5.53798 & -0.90708\end{array}$

(S)-2• D-phenylalanine

(alternative gauche conformations for both ethylenediamine, binaphthyl gap occupied by phenyl group, alternative)

$\Delta \mathrm{G}: 15.8 \mathrm{kcal} / \mathrm{mol}$

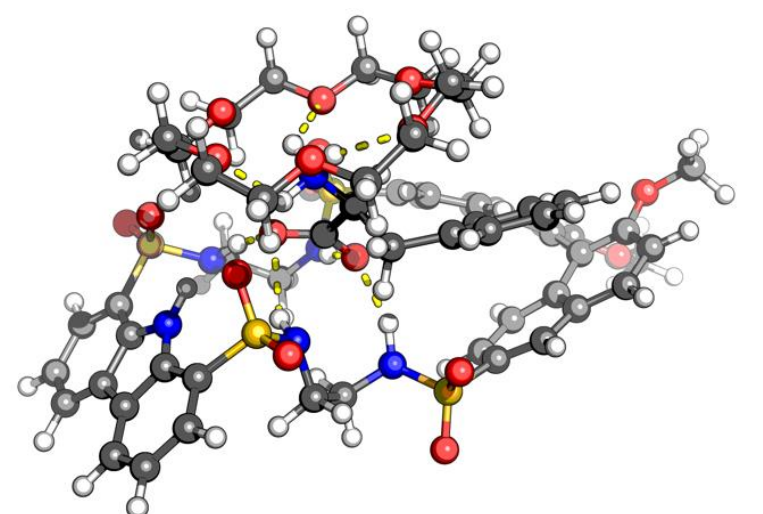

\begin{tabular}{|c|c|c|c|}
\hline I & -5.30048 & 2.08090 & 4.11112 \\
\hline $\mathrm{C}$ & -6.55968 & 0.32842 & 4.35879 \\
\hline C & -6.88358 & -0.93147 & 3.87100 \\
\hline $\mathrm{H}$ & -7.60364 & -1.55257 & 4.39509 \\
\hline $\mathrm{C}$ & -6.26795 & -1.40074 & 2.70949 \\
\hline $\mathrm{C}$ & -6.33668 & -2.64118 & 1.96419 \\
\hline $\mathrm{C}$ & -7.05103 & -3.83122 & 2.12588 \\
\hline $\mathrm{H}$ & -7.73635 & -3.94850 & 2.95980 \\
\hline $\mathrm{C}$ & -6.87916 & -4.85802 & 20856 \\
\hline C & -6.00242 & -4.70878 & 0.12456 \\
\hline $\mathrm{H}$ & -5.87597 & -5.49608 & -0.61137 \\
\hline $\mathrm{C}$ & -5.28550 & -3.53568 & -0.04326 \\
\hline C & -5.44865 & -2.49690 & 0.87742 \\
\hline $\mathrm{C}$ & -5.33164 & -0.58644 & 2.03178 \\
\hline $\mathrm{C}$ & -4.98938 & 0.66641 & 2.55085 \\
\hline $\mathrm{C}$ & -2.02723 & 0.13540 & 3.45111 \\
\hline $\mathrm{H}$ & -2.90064 & -0.32119 & 3.94045 \\
\hline $\mathrm{H}$ & -1.74016 & 1.03094 & 4.01035 \\
\hline C & -0.88437 & -0.87446 & 3.44154 \\
\hline $\mathrm{H}$ & -0.73130 & -1.24134 & 4.45888 \\
\hline $\mathrm{H}$ & -1.15335 & -1.72928 & 2.80984 \\
\hline $\mathrm{C}$ & 2.89392 & 0.25056 & 3.32523 \\
\hline $\mathrm{C}$ & 3.81159 & 1.25309 & 3.16763 \\
\hline $\mathrm{H}$ & 3.56796 & 2.27114 & 3.46043 \\
\hline $\mathrm{C}$ & 5.03396 & 0.98120 & 2.49443 \\
\hline C & 5.99350 & 1.99210 & 2.25055 \\
\hline $\mathrm{H}$ & 5.86488 & 2.96306 & 2.72033 \\
\hline $\mathrm{C}$ & 7.04603 & 1.77588 & 1.39691 \\
\hline $\mathrm{H}$ & 7.76334 & 2.56851 & 1.22255 \\
\hline $\mathrm{C}$ & 7.15365 & 0.54581 & 0.69385 \\
\hline $\mathrm{C}$ & 6.25751 & -0.48494 & 0.93339 \\
\hline $\mathrm{C}$ & 5.23123 & -0.29785 & 1.90559 \\
\hline $\mathrm{C}$ & 4.32287 & -1.34508 & 2.24250 \\
\hline $\mathrm{H}$ & 4.52276 & -2.35185 & 1.89451 \\
\hline $\mathrm{C}$ & 3.18186 & -1.08338 & 2.94207 \\
\hline $\mathrm{H}$ & 2.46037 & -1.86484 & 3.14813 \\
\hline $\mathrm{C}$ & 6.23793 & -1.72409 & 0.11001 \\
\hline $\mathrm{C}$ & 7.26673 & -2.65133 & 0.16329 \\
\hline $\mathrm{C}$ & 7.15168 & -3.89706 & -0.50659 \\
\hline $\mathrm{H}$ & 7.96218 & -4.61433 & -0.46832 \\
\hline $\mathrm{C}$ & 5.98936 & -4.22691 & -1.15671 \\
\hline $\mathrm{H}$ & 5.88415 & -5.20598 & -1.61521 \\
\hline $\mathrm{C}$ & 4.90559 & -3.32030 & -1.22097 \\
\hline $\mathrm{C}$ & 3.64080 & -3.69583 & -1.75574 \\
\hline $\mathrm{H}$ & 3.47155 & -4.70787 & -2.11300 \\
\hline C & 2.61875 & -2.78928 & -1.75593 \\
\hline C & 2.80302 & -1.45342 & -1.32621 \\
\hline $\mathrm{H}$ & 1.96915 & -0.75818 & -1.38062 \\
\hline C & 4.00189 & -1.08945 & -0.78770 \\
\hline $\mathrm{H}$ & 4.13870 & -0.08073 & -0.42095 \\
\hline C & 5.06704 & -2.02840 & -0.64591 \\
\hline 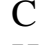 & -0.57314 & -4.31195 & -0.19582 \\
\hline $\mathrm{H}$ & 0.00008 & -5.23810 & -0.28736 \\
\hline$\pi$ & -0.76494 & -4.12705 & 0.86496 \\
\hline C & -1.88751 & -4.47862 & -0.945 \\
\hline
\end{tabular}




\begin{tabular}{|c|c|c|c|c|c|c|c|}
\hline $\mathrm{H}$ & -2.44203 & -5.32126 & -0.51928 & $\mathrm{C}$ & -1.19604 & -0.23298 & -4.58436 \\
\hline $\mathrm{H}$ & -1.68451 & -4.70688 & -1.99738 & $\mathrm{H}$ & -0.74413 & -1.20694 & -4.80946 \\
\hline $\mathrm{C}$ & 9.00053 & 1.35902 & -0.56011 & $\mathrm{H}$ & -1.35357 & 0.32328 & -5.52170 \\
\hline $\mathrm{H}$ & 9.61641 & 1.61439 & 0.30990 & $\mathrm{H}$ & 9.64115 & 0.97317 & -1.35236 \\
\hline $\mathrm{H}$ & 8.48719 & 2.25989 & -0.91717 & $\mathrm{H}$ & 10.14338 & -2.77676 & 1.67009 \\
\hline $\mathrm{C}$ & 9.40484 & -3.24131 & 1.01766 & $\mathrm{H}$ & -7.03121 & 0.69827 & 5.26194 \\
\hline $\mathrm{H}$ & 9.85861 & -3.43558 & 0.03878 & $\mathrm{H}$ & -7.43017 & -5.78459 & 1.32248 \\
\hline $\mathrm{H}$ & 9.07855 & -4.18953 & 1.46085 & $\mathrm{C}$ & -0.18321 & 2.39543 & 0.45284 \\
\hline $\mathrm{O}$ & 0.06866 & -0.50937 & 0.11493 & $\mathrm{H}$ & 0.31798 & 1.55028 & -1.48855 \\
\hline $\mathrm{O}$ & -1.99305 & -0.35169 & -0.75619 & $\mathrm{H}$ & -0.88060 & 3.23681 & 0.53317 \\
\hline $\mathrm{N}$ & -1.63797 & 2.18790 & -1.57820 & $\mathrm{H}$ & -0.34820 & 1.79485 & 1.35113 \\
\hline $\mathrm{H}$ & -1.43612 & 3.17530 & -1.79530 & $\mathrm{C}$ & 1.23460 & 2.91511 & 0.45708 \\
\hline $\mathrm{H}$ & -2.53203 & 2.13627 & -1.06594 & $\mathrm{C}$ & 1.50296 & 4.26239 & 0.70251 \\
\hline $\mathrm{H}$ & -1.79777 & 1.68769 & -2.47225 & $\mathrm{C}$ & 2.30592 & 2.05516 & 0.19502 \\
\hline $\mathrm{C}$ & -0.53235 & 1.56884 & -0.80863 & $\mathrm{C}$ & 2.80185 & 4.75819 & 0.63879 \\
\hline $\mathrm{C}$ & -0.86387 & 0.10608 & -0.47385 & $\mathrm{H}$ & 0.67919 & 4.93091 & 0.93735 \\
\hline $\mathrm{O}$ & -0.34165 & 0.51261 & -3.73463 & $\mathrm{C}$ & 3.60522 & 2.55215 & 0.10973 \\
\hline $\mathrm{O}$ & 1.01651 & 2.85597 & -3.39030 & $\mathrm{H}$ & 2.10410 & 0.99248 & 0.05548 \\
\hline $\mathrm{O}$ & -0.09090 & 4.88997 & -1.77761 & $\mathrm{C}$ & 3.85733 & 3.90491 & 0.32359 \\
\hline $\mathrm{O}$ & -2.79957 & 5.09167 & -1.34962 & $\mathrm{H}$ & 2.98847 & 5.81123 & 0.82819 \\
\hline $\mathrm{O}$ & -4.21986 & 2.92694 & -2.13208 & $\mathrm{H}$ & 4.43806 & 1.88975 & -0.11130 \\
\hline $\mathrm{O}$ & -3.10561 & 0.82854 & -3.67766 & $\mathrm{H}$ & 4.87270 & 4.28417 & 0.25677 \\
\hline $\mathrm{C}$ & 0.91582 & 0.68746 & -4.34209 & & & & \\
\hline $\mathrm{H}$ & 0.78252 & 1.09308 & -5.35729 & & & & \\
\hline $\mathrm{H}$ & 1.43914 & -0.27802 & -4.41273 & & & & \\
\hline $\mathrm{C}$ & 1.74738 & 1.65917 & -3.54185 & & & & \\
\hline $\mathrm{H}$ & 2.01727 & 1.24449 & -2.55727 & & & & \\
\hline $\mathrm{H}$ & 2.68931 & 1.84415 & -4.08273 & & & & \\
\hline $\mathrm{C}$ & 1.80946 & 3.88576 & -2.84789 & & & & \\
\hline $\mathrm{H}$ & 2.64646 & 4.12361 & -3.52569 & & & & \\
\hline $\mathrm{H}$ & 2.23084 & 3.58927 & -1.88027 & & & & \\
\hline $\mathrm{C}$ & 0.96932 & 5.12464 & -2.68402 & & & & \\
\hline $\mathrm{H}$ & 1.61875 & 5.92646 & -2.29906 & & & & \\
\hline $\mathrm{H}$ & 0.56071 & 5.44313 & -3.65445 & & & & \\
\hline $\mathrm{C}$ & -0.68591 & 6.10573 & -1.38249 & & & & \\
\hline $\mathrm{H}$ & -0.99093 & 6.68338 & -2.26783 & & & & \\
\hline $\mathrm{H}$ & 0.03165 & 6.71057 & -0.80471 & & & & \\
\hline $\mathrm{C}$ & -1.90410 & 5.81258 & -0.54448 & & & & \\
\hline $\mathrm{H}$ & -1.63229 & 5.23581 & 0.35387 & & & & \\
\hline $\mathrm{H}$ & -2.35053 & 6.76143 & -0.20641 & & & & \\
\hline $\mathrm{C}$ & -3.99688 & 4.76286 & -0.67724 & & & & \\
\hline $\mathrm{H}$ & -4.49261 & 5.67259 & -0.30340 & & & & \\
\hline $\mathrm{H}$ & -3.78908 & 4.10380 & 0.17814 & & & & \\
\hline $\mathrm{C}$ & -4.89821 & 4.06217 & -1.66510 & & & & \\
\hline $\mathrm{H}$ & -5.83359 & 3.77664 & -1.15884 & & & & \\
\hline $\mathrm{H}$ & -5.14460 & 4.73803 & -2.49861 & & & & \\
\hline $\mathrm{C}$ & -5.00478 & 2.06577 & -2.92543 & & & & \\
\hline $\mathrm{H}$ & -5.12971 & 2.48055 & -3.93647 & & & & \\
\hline $\mathrm{H}$ & -6.00035 & 1.93693 & -2.47389 & & & & \\
\hline $\mathrm{C}$ & -4.32690 & 0.72094 & -2.96931 & & & & \\
\hline $\mathrm{H}$ & -4.13684 & 0.37691 & -1.94537 & & & & \\
\hline $\mathrm{H}$ & -4.98323 & -0.01406 & -3.45469 & & & & \\
\hline $\mathrm{C}$ & -2.50756 & -0.44500 & -3.88324 & & & & \\
\hline $\mathrm{H}$ & -3.16614 & -1.07421 & -4.49909 & & & & \\
\hline $\mathrm{H}$ & -2.34070 & -0.94592 & -2.92498 & & & & \\
\hline
\end{tabular}




\section{REFERENCES}

[1] a) Sheldrick, G. M. SHELXS 97, Program for crystal Structure Solution, 1997, University of Göttingen.; b) G. M. Sheldrick, SHELXL 97, Program for crystal Structure Refinement, 1997, University of Göttingen.

[2] Yang, X.; Lu, R.; Gai, F.; Xue, P.; Zhan, Y. Chem. Commun. 2010, 46, 1088-1090.

[3] Fuentes de Arriba, Á. L.; Turiel, M. G.; Simón, L.; Sanz, F.; Boyero, J. F.; Muñiz, F. M.; Morán, J. R.; Alcázar, V. Org. Biomol. Chem. 2011, 9, 8321-8327.

[4] Kyba, E. P.; Siegel, M. G.; Sousa, L. R.; Sogah, G. D.; Cram, D. J. J. Am. Chem. Soc. 1973, 95, 2691-2692.

[5] Hernández, J. V.; Oliva, A. I.; Simón, L.; Muñiz, F. M.; Grande, M.; Morán, J. R. Tetrahedron Lett. 2004, 45, 4831-4833.

[6] Tanaka, K.; Okada, T.; Toda, F. Angew. Chem. Int. Ed. 1993, 32, 1147-1148; Angew. Chem. 1993, 105, 1266-1267.

[7] Frisch, M. J.; Trucks, G. W.; Schlegel, H. B.; Scuseria, G. E.; Robb, M. A.; Cheeseman, J. R.; Scalmani, G.; Barone, V.; Petersson, G. A.; Nakatsuji, H.; Li, X.; Caricato, M.; Marenich, A. V.; Bloino, J.; Janesko, B. G.; Gomperts, R.; Mennucci, B.; Hratchian, H. P.; Ortiz, J. V.; Izmaylov, A. F.; Sonnenberg, J. L.; Williams-Young, D.; Ding, F.; Lipparini, F.; Egidi, F.; Goings, J.; Peng, B.; Petrone, A.; Henderson, T.; Ranasinghe, D.; Zakrzewski, V. G.; Gao, J.; Rega, N.; Zheng, G.; Liang, W.; Hada, M.; Ehara, M.; Toyota, K.; Fukuda, R.; Hasegawa, J.; Ishida, M.; Nakajima, T.; Honda, Y.; Kitao, O.; Nakai, H.; Vreven, T.; Throssell, K.; Montgomer Jr., J. A.; Peralta, J. E.; Ogliaro, F.; Bearpark, M. J.; Heyd, J. J.; Brothers, E. N.; Kudin, K. N.; Staroverov, V. N.; Keith, T. A.; Kobayashi, R.; Normand, J.; Raghavachari, K.; Rendell, A. P.; Burant, J. C.; Iyengar, S. S.; Tomasi, J.; Cossi, M.; Millam, J. M.; Klene, M.; Adamo, C.; Cammi, R.; Ochterski, J. W.; Martin, R. L.; Morokuma, K.; Farkas, O.; Foresman, J. B.; Fox, D. J. Gaussian, Inc., Wallingford CT, 2016.

[8] a) Zhao, Y.; Truhlar, D. G. Acc. Chem. Res. 2008, 41, 157-167; b) Zhao, H. Truhlar, D. G. Theor Chem Acta 2007, 120, 215-241.

[9] a) Gill, P. M. W.; Johnson, B. G.; Pople, J. A.; Frisch, M. J. Chem. Phys. Lett. 1992, 197, 499-505; b) Clark, T.; Chandrasekhar, J.; Schleyer, P. v. R. J. Comput. Chem. 1983, 4, $294-$ 301; c) Krishnan, R.; Binkley, J. S.; Seeger, R.; Pople, J. A. J. Chem. Phys. 1980, 72, 650654.

[10] Grimme, S.; Antony, J.; Ehrlich, S.; Krieg, H. J. Chem. Phys. 2010, 132, 154104.

[11] Grimme, S. Chem.--Eur. J. 2012, 18, 9955-9964.

[12] Funes-Adois, I.; Paton, R. 2017, https://github.com/bobbypaton/GoodVibes.

[13] Marenich, A. V.; Cramer, C. J.; Truhlar, D. G. J. Phys. Chem. B. 2009, 113, 6378-6396. 